\title{
Revisions of African Moraceae (excluding Dorstenia, Ficus, Musanga and Myrianthus)
}

by

\author{
C.C. Berg $\left({ }^{*}\right)$
}

\begin{abstract}
Summary. - In continuation of de Ruiter's treatment of Myrianthus and Musanga (Bull. Jard. Bot. Nat. Belg. 46: 471-510.1976), the present paper gives a revision of the African representatives of 17 genera of the Moraceae. The area studied not only consists of the African Continent, but also includes Madagascar, the Comoro Islands, the Mascarenes, the Seychelles, and the Aldabra Islands. Several new combinations are made: Antiaris toxicaria ssp. africana (Engl.) C.C. Berg, A. toxicaria ssp. africana var. usambarensis (Engl.) C.C. Berg, A. toxicaria ssp. macrophylla (R.Br.) C.C. Berg, A. toxicaria ssp. madagascariensis (H. Perrier) C.C. Berg, A. toxicaria ssp. humbertit (Léandri) C. C. Berg, Broussonetia greveana (Baillon) C.C. Berg, Treculia africana ssp. madagascarica (N.E.Br.) C.C. Berg, and $T$. africana ssp. madagascarica var. sambiranensis (Léandri) C.C. Berg. Many names are brought into synonymy. Besides revising taxa, the present study aims to fill a gap in our knowledge between Asian Moraceae (studied by Corner, whose studies resulted in a new classification of the family) and the neotropical Moraceae, a subject of study by the present author. Therefore discussions about classification of the family and relationships of African Moraceae with moraceous taxa elsewhere are an essential part of the present paper.
\end{abstract}

\section{Introduction}

As shown in recent studies on Moraceae (Corner 1962; Berg 1972b), our knowledge of the African Moraceae is rather poor. This is partly due to the facts that since Engler's (1898) and Rendle and Hutchinson's (1916, 1917) surveying treatments of the African Moraceae, the taxonomical work in this family has been mainly done on a regional basis, and that the moraceous flora of Madagascar, phytogeographically so important, has become fairly well known only since 1948 (Léandri 1948a, 1948b). Although the predominantly floristic treatments serve well for naming material from several regions, they did not truly enhance our insight into the relationships and the position of the taxa, not being

(*) Institute for Systematic Botany, State University of Utrecht, Trans. II, Heidelberglaan 2, Utrecht (Netherlands). - Manuscript received April 1, 1977. 
based on the examination of essential features by comparative studies. This particularly holds for the smaller genera. A contribution to a better knowledge and understanding of these genera in behalf of an improvement of the classification is the main aim of the present taxonomical revisions.

Material of the following herbaria was used for the present study: ABI, B, BM, BR, COI, E, FHI, FHO, G, HBG, K, L, LISC, LISU, $P, S, U$, UPS, WAG.

An index of specimens examined for the present study has been prepared and is available on request from the Institute for Systematic Botany, State University of Utrecht, Trans. II, Heidelberglaan 2, Utrecht, Netherlands. Maps giving the distribution of the taxa treated in the present paper will be published in the series "Distributiones Plantarum Africanarum".

\section{Classification of the Moraceae}

Corner's studies on Asian Moraceae (1962) led to a classification of the Moraceae that showed considerable change compared to the generally accepted system of the family proposed by Engler (1889). Corner (1962) transferred the Conocephaloideae, comprising the African genera Musanga and Myrianthus, to the Urticaceae, and divided the Moraceae s. str. into 6 tribes: Moreae, Artocarpeae, Dorstenieae, Brosimeae, Olmedieae, and Ficeae, involving re-arrangement of several genera. Many small genera were united to more inclusive ones (Streblus, Maclura, Trophis).

In the present author's opinion the Conocephaloideae are not more closely related to the Urticaceae than to the Moraceae s. str. It would be better to treat these three groups as subfamilies of a single family, the Urticaceae (Berg 1973), or as separate families. Partly as a conclusion of the present study I prefer a subdivision of the Moraceae s. str. into 4 tribes: Moreae (including Artocarpeae), Dorstenieae (including Brosimeae), Castilleae (the re-defined Olmedieae; Berg 1977), and Ficeae (cf. Berg 1973). Some arguments for this subdivision are discussed below under the separate tribes.

As clearly demonstrated by Corner (1962), several of the characters formerly used for differentiating subdivisions of the family fail. The structure of the inflorescences, which appeared to be the only sufficient basis left for a primary subdivision, proves to be less important and useful than supposed (cf. Corner 1962; Berg 1972b). At first sight quite 
different inflorescences prove to be morphologically less remote than presumed (see p. 271, 272; Berg 1977). Presently the Ficeae and the Castilleae may be regarded as well-defined. The former tribe is mainly defined by characters of the reproductive structures (cf. Corner 1962), but is otherwise extremely variable; the latter is defined by a combination of various characters and appears rather homogeneous. The Dorstenieae, mainly defined by the basically bisexual discoid (to globose or to urceolate) inflorescences, are less homogeneous, but the genera are morphologically more or less clearly linked. Some genera of the Dorstenieae, especially Utsetela and Helianthostylis, show distinct affinities to a group of the Moreae comprising Bleekrodeae, Fatoua, Sloetiopsis, and Sloetia, genera of which the inflorescences are essentially bisexual (see p. 281, 328). The Dorstenieae are clearly delimited against the Castilleae and the Ficeae. The Moreae look somewhat like a dump, without very distinct features, without apparent homogeneity, and partly, without clear-cut genera.

\section{Habit}

The African Moraceae show considerable variation in dimensions. Beside huge trees (more than $50 \mathrm{~m}$ tall), e.g. in Antiaris, one meets modest herbs (up to $5 \mathrm{~cm}$ high) in Dorstenia. A herbaceous (to suffrutescent) habit occurs in many species of Dorstenia and in Fatoua. Most arborescent or frutescent African Moraceae show sympodial growth and have biseriate leaves, at least on more or less horizontal branches. In some of them, like Treculia africana and Chlorophora excelsa, seedlings already have biseriate leaves. This growth habit matches the "model of Troll" one of the categories of growth habits of trees recognized by Halle \& Oldeman (1970).

Young trees of Antiaris and Chlorophora regia have stems with spirally arranged leaves and in continuous sequence form horizontal branches with biseriate leaves. These more or less distinctly phyllomorphic branches are shed in Antiaris. Adult trees of Antiaris have a system of permanent branches bearing the leaves in spirals and forming self-pruning phyllomorphic branches. $C$. regia probably attains the features of the "model of Troll" when becoming adult.

The trees are terrestrial, only Trilepisium madagascariense is occasionally epiphytic and strangling, like several Ficus species.

Morus mesozygia and Broussonetia greveana show abortion and shedding of shoot tips connected with intermittant growth. Distinct 
traces of intermittant growth can also be observed in adult specimens of Chlorophora excelsa and C. regia.

Distinct resting buds occur in Morus mesozygia (always axillary) and in Chlorophora excelsa and $C$. regia (mainly apical). Small resting buds resembling those of $M$. mesozygia can be found in Broussonetia greveana and Pachytrophe dimepate. In these three species the buds are closed, but in Ampalis mauritiana the axillary buds are open.

Short-shoots ending in a spine are found in Cardiogyne.

\section{Leaves}

The leaves of the species treated in the present paper are basically pinnately veined and brochidodromous. A more or less distinct tendency towards subtriplinerved venation is present in Morus mesozygia, Trilepisium madagascariense, and Utsetala gabonensis. In most species the differences between leaves of juvenile and adult specimens are not conspicuous. Antiaris toxicaria, Chlorophora excelsa and $C$. regia are exceptions.

Scale leaves only consisting of more or less modified and mostly connate stipules occur in short-shoots bearing the inflorescences (Castilleae, several genera of the Dorstenieae, Treculia), on short branches ending in a spine, as in Cardiogyne africana, or on the lower parts of normal shoots, especially if arising from resting buds the scales (of which are also more or less modified stipules) as can be found in several genera of the Moreae. The absence of normal leaves is distinctly connected with the presence of inflorescences. In Trilepisium scale leaves form a bud cover to protect the young inflorescence.

\section{Indument}

Beside unicellular hairs minute pluricellular hairs can be found in most species, mainly on the lower leaf surface and on young twigs. These hairs consist of one or two cells forming a stalk and several cells forming an oblongoid or globose head. These almost microscopic hairs are globosecapitate in most African species, but oblongoid-capitate in Trilepisium madagascariense, Mesogyne insignis, and Sloetiopsis usambarensis. They are often reddish or brownish. They were not observed in Maillardia and Fatoua.

The unicellular hairs are straight, more or less curled, or curved to 
uncinate. Uncinate hairs are found in all members of the Dorstenieae, and furthermore in Fatoua, Bleekrodea, Sloetiopsis, and Treculia. They are not found in other members of the Moreae, although some of them (Broussonetia greveana, Cardiogyne africana) have close relatives having uncinate hairs. Uncinate hairs are wanting in all Castilleae.

In Chlorophora excelsa the areoles on the lower leaf surface are covered by small hairs, forming extra-stomatal crypts.

\section{Inflorescences}

Almost all types of moraceous inflorescences occur in the African Moraceae. The inflorescence of the Moraceae (and the Urticaceae) appears to be basically a cymose system with pistillate flowers (centrally, basally) and staminate flowers (peripherally, distally) with a tendency to dorsiventral flattening resulting in adaxial orientation of the flowers. The flattening can explain the abaxial sterile groove or strip in spicate and racemose inflorescences. Condensation of the branch system, reduction of the number of flowers, and the development of unisexuality are the main lines in the differentiation of the inflorescence of the Moraceae. Condensation results in spicate, racemose, or capitate inflorescences, or in inflorescences with a (plane, convex, or concave) discoid, globose, or urceolate receptacle; the bracts may form a more or less distinct involucre. In contrast to the unisexual inflorescences in bisexual inflorescences the cymose pattern is more or less well-preserved or traceable (cf. Bernbeck 1932). Bleekrodea madagascariensis distinctly shows the presumed basic structure of the moraceous inflorescence.

There is a pronounced tendency to shorten the single elongate axis (of the spicate or racemose inflorescence) to a clavate to globose or even discoid axis (of the capitate inflorescence), involving reduction of the number of flowers, even to one, as in Maillardia. In this process the pistillate inflorescence (usually) preceeds. In some genera (Treculia, Cardiogyne) the staminate and pistillate are (almost) similar, in other genera they are slightly different as in Ampalis, Chlorophora (excelsa and regia), but there are also genera (Sloetiopsis and Maillardia) with very different inflorescences in the two sexes. These two genera have many-flowered staminate inflorescences and single-flowered pistillate ones. Shortening of the elongate axis usually results in indistinctness or disappearance of the sterile groove.

More or less pronounced pseudanthy occurs in the groups of the Moraceae (Castilleae and Dorstenieae) with discoid to urceolate recep- 
tacles, especially if they are involucrate or bear marginal bracts. Reduction in such inflorescences can also result in uniflorous pistillate inflorescences.

After having discredited several characters formerly used for a primary subdivision of the Moraceae, the structure of the inflorescence appeared to be left for this purpose (cf. Corner 1962). The unisexual discoid involucrate inflorescence was regarded as characteristic for the "Olmediae". For several reasons (cf. Berg 1977) Olmedia, Antiaropsis, and Sparattosyce had to be excluded from this tribe and transferred to the Moreae. These genera can be linked with undoubted members of the Moreae; Olmedia is linked with Trophis, which has mainly spicate or racemose inflorescences, but in Trophis involucrata capitate-involucrate pistillate inflorescences; the other two genera are linked with Phyllochlamys ( = Streblus sect. Phyllochlamys), a genus with capitate, involucrate inflorescences. According to Corner (1962) the inflorescences of Phyllochlamys can be regarded as derived from spicate (or racemose) ones. The cymose inflorescences of Bleekrodea are morphologically related to those of Utsetela and the neotropical genus Helianthostylis, both belonging to the Dorstenieae. Fatoua (with which Bleekrodea appears to be related) shows that cymose and spicate (to racemose) inflorescences are not remote structures, either. As these cases show or suggest, several apparently distinct types of the inflorescence are morphologically related, and features of the inflorescences thus have less value for a primary subdivision of the family than formerly supposed.

For well-founded considerations about the differentiation of the inflorescence and its significance for classification, functional aspects relating to pollination and dispersal should be taken into account, which is hardly possible at this moment, through lack of knowledge of them.

The inflorescences are borne in pairs in the leaf axils (which appears to be the basical situation in the Moraceae and the Urticaceae) or solitary (as commonly in Chlorophora excelsa and C. regia, Morus mesozygia, Ampalis mauritiana, and Broussonetia greveana) or on scaled short-shoots in the axils of the leaves or also on older branches (in Antiaris, Mesogyne, Treculia, Dorstenia, and Scyphosyce), down to the main branches (in Treculia). In Antiaris and Mesogyne the short-shoots may bear both pistillate (on the lower nodes) and staminate inflorescences, thus somewhat simulating the situation in a flower with regard to the position of male and female structures. The short-shoots may produce several to many inflorescences almost simultaneously or successively. In Trilepisium the inflorescences are initially enclosed in scaled buds in the leaf 
axils. In some genera (e.g. Morus) most fertile shoots are more or less intermediate between a normal shoot and a short-shoot; they form scale leaves at the base, and most inflorescences are borne there. The shortshoots may develop into normal shoots.

\section{Staminate flowers}

Inflexed stamens springing back at anthesis and ejecting their pollen are found in many species of the Moreae s.l. These stamens, with introrse anthers and a small connective, are adapted to windpollination. In the groups having these stamens the perianth is well-developed, the number of stamens is mostly four or five, and the pistillode is usually present and often rather large. In groups in which the stamens are straight in the bud, or if inflexed or incurved not springing back at anthesis (as in Dorstenia and Bosqueiopsis), the perianth often shows a reduction in the number and/or the size of the tepals, often accompanied by a reduction of the number of stamens, as well of the size of the pistillode. Moreover, the flowers may become more or less disorganized (as in Antiaris). In Trilepisium the perianth is lacking. If the perianth is more or less reduced or lacking, other structures are involved in the protection of the stamens, which is brought about in a peculiar manner in Trilepisium.

The inflexed stamens, characteristic for all Urticaceae, have been used for delimiting the subfamily Moroideae of the Moraceae. But as stated by Corner (1962), this feature cannot be used for delimitation at the subfamily or the tribe level, not even at the genus level. Under Maclura Corner brought together species with inflexed and others with straight stamens. There are several examples of pairs of (probably) more or less closely related taxa one of which has inflexed stamens, the other straight stamens: Trophis-Sorocea, Chlorophora (excelsa and C. regia)-Bagassa, Maclura-Cudrania, Phyllochlamys-Antiaropsis, and Malaisia-Prainea.

\section{Pistillate flowers}

With the exception of Treculia all genera treated have pistillate flowers with a well-developed perianth; this is indistinct if it is completely or largely fused with the receptacle. In Treculia the perianthless pistillate flowers are placed in cavities formed by the basally fused parts of the interfloral bracts. In the genera with free pistillate flowers and free pistils the perianth mainly varies in the degree to which the tepals are connate. 
Differences in the fruiting perianth are more important because of the role they play in the protection and dispersal of the fruits. These differences refer to the degree in which they develop further, to their substance or texture, and to their colour.

\section{Fruit}

A white pulpy exocarp splitting open in two valves and pushing upward (or outward) or ejecting the endocarp body occurs in several genera : Dorstenia, Scyphosyce, Utsetela, Sloetiopsis, Bleekrodea, Fatoua, and besides in several species of Streblus sensu Corner, in some species of Ficus (cf. Corner 1962), in Antiaropsis, and possibly in Sparattosyce. The exocarp has a thick fleshy base which may occupy about half of the length of the fruit. The endocarp body is clasped by the two valves. The valve at the seed-bearing side is rather straight and thicker than the other, which is curved over the endocarp body and towards the top strongly narrows to about the width of the lateral vascular bundle. The endocarp is released by a break at the top of the narrowed part (actually the vascular bundle). The stress on the endocarp body caused by the exocarp is suddenly released when the connecting part breaks. If small, the endocarp is often whitish or pale brown and may be more or less tuberculate (as in Fatoua and some Dorstenia species). These small endocarp bodies are probably ejected. The uneven surface of the endocarp body is probably advantageous for ejection, as in seeds of Oxalidaceae (cf. Overbeek 1923, 1926). Overbeek (1924) described the ejecting mechanism of fruits of Dorstenia contrajerva, said to be a pincer mechanism. It was further studied by Schleuss (1958). This study also contains an account of the development of the fruit of Dorstenia. If the endocarps are large, they are usually smooth and often black (Dorstenia species, Sloetiopsis). They are probably not ejected but only pushed away; or if the exocarps are relatively thin (as in Antiaropsis) they probably only slip away abruptly. In Dorstenia, Utsetela and Bleekrodea the endocarp can only be released after tearing of the surrounding tissue (the upper part of the infructescence or the fruiting perianth).

In some genera of the Moraceae, like Broussonetia and Chlorophora (excelsa and regia), the oblongoid fruit has an indehiscent white and thinly fleshy exocarp with a short stipe, as in the dehiscent fruit. A drawing of the fruit of Broussonetia papyrifera given by Seringe (1855) suggests the (occasional?) occurrence of a thickly fleshy (and dehiscent) 
exocarp in that genus. It is conceivable that the fruit as occurring in Chlorophora is derived from the dehiscent fruit. In Morus, Ampalis, and Pachytrophe the exocarp is also more or less succulent. In the broad bases of their fruits these genera differ distinctly from Broussonetia and Chlorophora. On the other hand, the fact that the exocarp becomes thicker toward the parts containing the (lateral) vascular bundles, as found in the dehiscent fruit, suggest that this broad-based indehiscent fruit is also derived from the dehiscent fruit. Broad-based fruits also occur in some Streblus species, like $S$. ascendens, S. pendulinus, and S. sclerophylla (Corner 1970).

In Treculia the exocarp is thin-fleshy in T. africana, but coriaceous in $T$. acuminata and $T$. obovoidea.

It may be said that drupes are rather common among the Moraceae with free fruits. In other Moraceae, like Maillardia, the fruit is adnate to the fleshy fruiting perianth and forms a drupe-like structure with it. In Antiaris, Mesogyne, Trilepisium, and Bosqueiopsis the fruit (adnate to the perianth) forms a drupaceous whole with the surrounding fleshy receptacle.

In most Moraceae the endocarp is woody, crustaceous (or coriaceous). It has functionally replaced the testa, which is usually thin or very thin. The testa usually shows a more or less extensive system of vascular bundles departing from the hilum. Below the hilum there usually is an oblong to orbicular thickened part of the testa to which the vascular bundles are often confined. Depending on the position of the embryo and the hilum, the thickened part is apical or lateral. The significance of the thickened part is not clear.

The embryo shows much variation. In several small-seeded Moreae (Fatoua, Morus, Chlorophora, and Broussonetia) the seed contains endosperm and an embryo with almost plane cotyledons and a long radicle. In other genera of the Moreae (Pachytrophe, Treculia) traces of endosperm can be found. The cotyledons vary from equal to very unequal, from plane to conduplicate to plicate, and from flat to almost cylindrical; the radicle varies from long to very short.

\section{Pollination}

Except for Treculia all African members of the Moreae have stamens that bend outward abruptly and elastically at anthesis and eject their pollen. Transport of this pollen demands more or less open habitats (semi-deciduous or deciduous forests, forest edges, riversides). This may 
explain the remarkable abundance of Chlorophora just behind littoral bush, as in the Ivory Coast (Aubréville et al. 1947; cf. Aubréville 1959). A short period of leaflessness just before flowering (as occurs in Antiaris, Chlorophora, and Morus) is advantageous for wind pollination. Sloetiopsis which often inhabits dense forests is there almost confined to the side of streamlets, places where air movement may be expected. According to Osmaston (1965) Antiaris is probably also wind pollinated. If passive release of pollen by mere dropping is effective enough, wind pollination may also occur in Trilepisium where the inflorescences initially point downwards. The remarkable affixture of the anthers of $T$. africana might also be an indication of wind pollination. However, many labels report that the staminate inflorescences are odoriferous. The strong sweet smell is said to be pleasant, unpleasant, or disgusting, and seems to attract beetles which may use the staminate inflorescences as brood-places. Labels also report that the inflorescences of Trilepisium madagascariense, and the staminate inflorescences of Mesogyne insignis are sweetly scented.

\section{Dispersal}

It is known that the fruits of Antiaris, Chlorophora excelsa, Treculia africana, and Cardiogyne are eaten by various animals. It may be assumed that greenish infructescences somewhat resembling those of Chlorophora exelsa (like those of Morus mesozygia) and the infructescences with a coloured and more or less fleshy receptacle or fruiting perianth are also eaten and dispersed by animals.

The situation is different in a group of species the fruits of which have a white pulpy dehiscent exocarp which pushes upwards or ejects the endocarp body. These fruits, enclosed by a green (or, in several Dorstenia species, a brownish to purplish) receptacle and enveloped by a green (or in Scyphosyce manniana slightly purplish) perianth and often hidden under the leaves, are inconspicuous. The smaller whitish or larger blackish endocarp bodies are dropped close by the plant and might be transported further by water. Many of the species concerned are gregarious. In several of them this is due to the presence of repent rhizomes, but in other species, like Sloetiopsis usambarensis, the way of dispersal may provide an explanation for this phenomenon, as well as for the fact that the species are usually found along streams. In this group of species only Bleekrodea madagascariensis has a reddish fruiting perianth, which has to be torn to release the endocarp body. The colour of the perianth, contrasting with the black endocarp might attract animals. 


\section{Chemical substances}

In many members of the Moreae a yellow dye occurs in several parts of the plant. This may often be more or less accumulated in certain parts imparting to them a yellow or orange colour, e.g. in the bark of the roots, in the tepals and bracts as in Cardiogyne africana, or in the connectives of the anthers.

The latex of Treculia africana and Antiaris toxicaria is said to be toxic. This may be ascribed to cardiac glycosides in $A$. toxicaria, in $T$. africana to a poisonous substance, possibly similar to that of Parartocarpus. Conspicuous change in colour of the latex from whitish to brownish or reddish, after exposure to the air is known in Antiaris toxicaria, Treculia africana and in Trilepisium madagascariense. The latex of Trilepisium is a dye. Latex and even laticiferous elements seem to be lacking in Fatoua madagascariensis (Léandri 1948b).

\section{Chromosome numbers}

Chromosome numbers of only a few of the African Moraceae treated in the present study are known :

- Antiaris africana 2n $=28$ Le Coq (1964)

(= A. toxicaria ssp. africana var. africana?)

- Antiaris usambarensis 2n 28 Le Coq (1964)

(= A. toxicaria ssp. africana var. usambarensis?)

- Antiaris welwitschii 2n $=24$ Mangenot \& Mangenot (1958)

(= A. toxicaria ssp. africana var. welwitschii?)

- Bosqueia angolensis 2n 28 Gadella \& Kliphuis (1969)

(= Trilepisium madagascariense)

- Scyphosyce manniana 2n 28 Cameroun, near Loum Leeuwenberg \& Berg 9759)

Judging from the indices of chromosome numbers (Le Coq 1963; Fedorov 1969) $2 n=28$ seems to be a common chromosome number in the Moraceae.

\section{Distribution}

The Moreae have their center in Asia, which is also evident from the distribution and the relationships of the African members of the tribe. Eight of the eleven genera (distinguished by provisionally adopting a 
very narrow genus concept) occur in Madagascar. Only Treculia and Cardiogyne (only known from a single locality in Madagascar) also occur on the African continent, inhabited by five genera. These genera or species have their closest relatives in Asia. If in anticipation we adopt a broader genus concept, we may even say that none of the genera is endemic to Africa, possibly except for the genus which might be formed by Chlorophora excelsa and $C$. regia. These species appear to be related to the neotropical genus Bagassa (see p. 273). Most of the species of this tribe are not (true) components of (humid) rain forests. Chlorophora excelsa, Morus mesozygia, Treculia africana, and Sloetiopsis usambarensis have a wide distribution in tropical Africa. Chlorophora regia is confined to a rather small area in West Africa, the other two species of Treculia inhabit the rain forest area ranging from S.E. Nigeria to the Lower Congo River. Cardiogyne africana chiefly inhabits coastal areasi $\mathbf{n}$ East Africa. Maillardia borbonica is an endemic of Mauritius, M. montana extends from Madagascar to the Comoro Islands and Aldabra Atoll. Except for Fatoua madagascariensis the Madagascan Moreae are more or less widely distributed on the island.

In Asia the Dorsteniae are only represented by some Dorstenia species. The tribe has distinct trans-atlantic connections. In contrast to the Moreae, the Dorstenieae are more or less centered in western Africa. Many of the species are true components of humid rain forests, especially of the undergrowth, and are (almost) confined to the rain forest area between the Cross River in S.E. Nigeria and the Lower Congo River. Furthermore, many species have small areas. But Trilepisium madagascariense, extending outside the rain forest areas, ranges from West Africa to Madagascar and to the Seychelles; Bosquieopsis gilletii and Dorstenia kameruniana have rather wide, in their disjunctions more or less similar areas, the former from East Africa to the Lower Congo River, the latter up to S.E. Guinea (Mount Nimba). The Castilleae are chiefly neotropical, extending to Africa only with the two closely related monotypic genera Antiaris and Mesogyne. Antiaris toxicaria ranges from Senegal to Madagascar and from Sri Lanka to the Tonga Islands. In Africa it extends far outside rain forest areas. Mesogyne, with a peculiar disjunct area (Eastern Tanzania - São Tomé) appears to be a component of the rain forest and in this aspect resembles most of its neotropical relatives.

Most arborescent species of the African Moraceae (as far as treated in the present paper) may inhabit relatively dry regions, or at least more or less open vegetations. They occur in semi-deciduous or deciduous forests, gallery forests, in forest islands or as solitary trees in savanna 
regions, or along streams. Chlorophora excelsa and Antiaris toxicaria may be co-dominant in forests bordering savanna areas (observed in Togo). Those arborescent species often occur in secondary vegetations or as lone trees spared in cultivated areas. Most of them (appear to) penetrate into rain forests areas, where some of them (e.g. Treculia africana) are mostly found along streams. They are not frequent in the dense humid upland forests. They probably appear there due to accidental clearings (cf. Aubréville 1959). The Chlorophora species and Antiaris toxicaria are known to be light demanding (Aubréville 1959; Voorhoeve 1965).

Sloetiopsis usambarensis is a remarkable species. It may inhabit (as a shrub or a small tree) dense primary forests, but (as a small, muchbranched shrub) also rocks in riverbeds or coastal scrub vegetations. This suggests that the seeds germinate under quite different (light) conditions. Other species, like Bosquieopsis gilletii, may also prove to have this property.

True components of humid rain forests are the two Scyphosyce species, Utsetela gabonensis, Treculia acuminata, and Mesogyne insignis. All are components of the undergrowth. The main area of these species extends from S.E. Nigeria to the Lower Congo River. Treculia obovoidea, also occurring in this region, may too be regarded as a true component of the humid rain forest, although the small to medium-sized trees often occur along streams.

Several taxa show considerable ecological amplitude with regard to humidity (Cardiogyne africana, Sloetiopsis usambarensis, several Madagascan species). Drought conditions may influence habit (Sloetiopsis usambarensis), leaf characters (Sloetiopsis usambarensis, Antiaris toxicaria), and leaf-fall.

Infra-specific or specific differentiation in relation to the kind of soil or to altitude, as suggested for several Madagascan Moraceae (cf. Léandri 1948a, 1948b; Perrier de la Bâthie \& Léandri 1952) is not apparent.

Key to the tribes of the Moraceae s. str.

1.a. Inflorescences urceolate, the opening entirely closed by (ostiolar) bracts

. . . . . . . . . . . . . . . . . . . . . . . Ficeae

b. Inflorescences mostly spicate, capitate, or discoid, if urceolate then the opening not entirely closed . . . . . . . . . . . . . . . . . . .

2.a. Inflorescences discoid to turbinate, sometimes cyathiform or capitate, often more or less distinctly involucrate; stamens straight in the bud, or, if inflexed, then straightening gradually .....................

b. Inflorescences mostly spicate to racemose or capitate or sometimes shortly branched cymes (in some Asian genera discoid and involucrate or urceolate, 
subinvolucrate in Treculia and some Asian genera) usually unisexual; stamens often infiexed and bending outward elastically at anthesis . . . . . Moreae

3.a. Inflorescences bisexual or rarely unisexual by reduction, interfloral bracts usually peltate uncinate; hairs always present; self-pruning branches lacking

.................. Dorstenieae

b. Inflorescences unisexual, bracts never peltate; uncinate hairs lacking; with

self-pruning branches ............ Castilleae

Dorstenieae Gaudich.

in Freyc., Voy. Monde Bot. : 491, 510 (1830)

Trees, shrubs, or herbs (Dorstenia). Leaves distichous or in a spiral; stipules connate or not; uncinate hairs general; wood without septate fibres. Inflorescences solitary or paired, rarely in small groups on shortshoots, mostly bisexual, discoid to globose; involucre lacking or if present generally not consisting of several series of imbricate bracts; often peltate bracts among the flowers; stamens straight or curved (but not elastically springing back); sometimes a distinct pistillode; perianth of the pistillate flower with connate tepals. Fruit free or forming a drupaceaous whole with the receptacle; seeds large or small, without or with endosperm; testa generally having a thickened part with vascular strands; embryo often not oriented longitudinally in the seed, cotyledons often unequal.

In this circumscription (cf. Berg 1973) the tribe comprises Dorstenia, Scyphosyce, Utsetela, Bosqueiopsis, and Trilepisium, and further the neotropical genera Brosimum, Trymatococcus, and Helianthostylis.

Because of the inflexed stamens Dorstenia was formerly classed far from the Brosimeae (cf. Trécul 1847; Bureau 1873; Engler 1889). The inflexed stamens of Dorstenia do not suddenly spring back at anthesis to release the pollen, as in many members of the tribe Moreae and in the Urticaceae, and have therefore been regarded as distinct.

When the diagnoses of the Dorstenieae and the Brosimeae, as given by Corner (1962) in a key to the tribes of the Moraceae, are compared, the two tribes approach each other: the diagnoses do not include essential differentiating characters. In Corner's concept the tribe Dorstenieae only comprises the genus Dorstenia, which is very uniform to the basic characters of inflorescence and flower. That uniformity is not affected by combining the species formerly put in Craterogyne with Dorstenia. However, D. djettii is a remarkable exception in having interfloral peltate bracts, like Bosqueiopsis and the neotropical genus Brosimum. In this feature D. djettii distinctly links Dorstenia with genera formerly placed in the Brosimeae. 
Scyphosyce resembles in habit and habitat many species of Dorstenia. It is not very difficult to connect the structure of the inflorescence of $S$. manniana via that of $S$. pandurata with the inflorescence of Dorstenia. $S$. manniana has an inflorescence with free flowers and a pistillate flower with free tepals. $S$. pandurata has basally fused staminate flowers and a pistillate flower with connate tepals whereas in the inflorescence of Dorstenia all flowers are fused except for their upper parts. Scyphosyce and Dorstenia have the same type of fruit (with a white thick-fleshy dehiscent exocarp, pushing upward or ejecting the endocarp body). The same type of fruit also occurs in Utsetela.

Utsetela (inserted in the Dorstenieae on the basis of the structure of the inflorescence, only distinct when fruiting) in its inflorescence resembles Bleekrodea. Thus Bleekrodea links the Dorstenieae with a group of the Moreae comprising, beside Bleekrodea, Sloetiopsis, Sloetia [according to Corner (1962) to be regarded as members of the broad genus Streblus], and Fatoua. In this group bisexual inflorescences are predominant, as in the Dorstenieae. Moreover, this group of genera matches most Dorstenieae in their indument and several genera of the Dorstenieae in their fruits. But they distinctly differ in the stamens, which suddenly spring back at anthesis. The inflorescence of Utsetela also resembles the bisexual inflorescences of the neotropical genus Helianthostylis; however, in the latter the fruit is not free but fused with the receptacle. The capitate staminate inflorescences of Helianthostylis do not have a distinct receptacle but are compactly branched like the inflorescence of Bleekrodea.

The striking resemblance between Bleekrodea and Utsetela is puzzling. The main difference between these taxa is found in the type of stamens. The difference between inflexed stamens which bend outward elastically and straight stamens or inflexed stamens which do not bend outward elastically appears not to be important for classification and delimination of genera in the Moreae (cf. Corner 1962) which is not surprising considering the lack of homogenity in this tribe. Several characters which are distinctive for groups of the Urticales like inflexed stamens for the Urticeae s. str., are apparently distributed at random in the Moreae. On the other hand, differences in the type of stamens seem to be fundamental with regard to evolutionary patterns in the Urticales, especially in relation to pollination.

Beside connections to several genera of the Dorstenieae, the Bleekrodea-Fatoua-Sloetiopsis group appears to be connected to the Urticaceae s. str. through Fatoua. The presence of primitive features in the inflorescences and flowers and the presumably primitive dehiscent fruits suggest 
that the Bleekrodeae-Fatoua-Sloetiopsis group and several genera of the Dorstenieae are still close to an ancestral (?) morphological complex to which several differentiation lines go back. Some of these lines involve adaptations to wind pollination (in Bleekrodea, etc.), in others to insect pollination (Utsetela, etc.).

The inflorescences of Bosqueiopsis resemble those of the neotropical genus Trymatococcus. In these two genera, and besides in Trilepisium and the neotropical genera Brosimum and Helianthostylis the pericarp, the (lower part of the) perianth of the pistillate flower, and the receptacle are fused and form a drupaceous whole. In the characters of the (bisexual) inflorescences (especially when fruiting) Helianthostylis resembles Trymatococcus and links Utsetela with other members of the Dorstenieae. Therefore, it appears impossible to separate Utsetela and Helianthostylis, the characters of the inflorescences of which approach those of Bleekrodea, from the other genera of the Dorstenieae.

It has to be mentioned that Bureau (1873) placed Fatoua, Sloetia and Bleekrodea in the tribe Dorstenieae, in which Engler $(1889,1915)$ also placed Sloetiopsis and Neosloetiopsis, thus disregarding differences in the structure of the inflorescence (see p. 363).

\section{Key to the genera of the Dorstenieae}

1.a. Staminate flowers without a perianth and before anthesis enclosed by the expanded margin of the receptacle; young inflorescences in scaly buds; stipules fully amplexicaul; twigs mostly glabrous ......... 5. Trilepisium

b. Staminate flowers with a perianth; inflorescences not in buds; stipules not fully amplexicaul; twigs mostly with hairs . . . . . . . . . . 2

2.a. Inflorescences cyathiform; low undershrubs ........ 2. Scyphosyce

b. Inflorescences discoid to turbinate (or naviculate) or capitate; trees, shrubs, undershrubs or herbs . . . . . . . . . . . . . . 3

3.a. Inflorescences capitate, with 4 subtending bracts; infructescences globose with 4 subtending bracts; infructescences globose with scattered remnants of the staminate flowers; leaves subtriplinerved . . . . . . . . 3. Utsetela

b. Infiorescences discoid to turbinate (or naviculate), with marginal bracts; remnants of staminate flowers crowded on the upper surface of the receptacle; leaves pinnately veined or (in Bosqueiopsis) subtriplinerved . . . . .

4.a. Inflorescences with persistent, peltate, interfloral bracts; overy and fruit adnate to the receptacle; leaves subtriplinerved; trees or shrubs . 4. Bosqueiopsis

b. Inflorescences without interfloral bracts (or with caducous, peltate, interfloral bracts in $D$. djettii); ovary and fruit free; leaves pinnately veined; shrubs, undershrubs or herbs .............. 5. Dorstenia

1. Dorstenia L., Sp. Pl. : 121 (1753). - Type species : D. contrajerva L.

Kosaria Forsk., Fl. Aegypt Arab. : 164 (1755).

Craterogyne Lanj., Rec. Trav. Bot. Neérl. 32 : 272 (1935). - Type 
species: C. africana (Baill.) Lanj. [= Dorstenia africana (Baill.) C.C. Berg].

Ctenocladus Engl., Bot. Jahrb. $57: 246$ (1921), nom. reject., = Ctenocladium Airy Shaw, Kew Bull. 18 : 272 (1965). - Type species: Ctenocladus mildbraedii Engl. = Ctenocladium mildbraedii (Engl.) Airy Shaw.

Four of the five species which together form the genus Craterogyne namely C. africana (Baill.) Lanj., C. kameruniana (Engl.) Lanj., C. oligogyna (Pellegr.) Lanj., and C. djettii (Guillaumet) N. Hallé \& Aké Assi, show relationships to Dorstenia elliptica Bur., the only species of Dorstenia sect. Nothodorstenia Engl. The fifth species, $C$. dorstenioides (Engl.) Lanj., shows a distinct relationship to Dorstenia turbinata Engl. which belongs to another group of Dorstenia, related to sect. Nothodorstenia.

Because of the resemblances of the Craterogyne species with Dorstenia species and the lack of good differential characters between Craterogyne and Dorstenia, the two genera must be united. The five Craterogyne species are now to be referred to as Dorstenia africana (Baill.) C.C. Berg, D. kameruniana Engl., D. oligogyna (Pellegr.) C.C. Berg, D. djettii Guillaumet, and D. dorstenioides (Engl.) M. Hijman \& C.C. Berg, respectively (see Berg \& Hijman 1977). Except for D. dorstenioides, those species can be placed in the section Nothodorstenia.

The revision of this group of Dorstenia species does not fit very well in the present paper and will be published separately.

Mainly due to the presence of (caducous) peltate interfloral bracts D. djettii links Dorstenia with other members of the tribe Dorstenieae.

Ctenocladus was based on a monstrosity. It has to be rejected for that reason (Intern. Code Art. 17). The inflorescences of the type specimen (which might belong to Dorstenia psilurus) have developed in an abnormal way by repeated braching.

2. Scyphosyce Baillon, Adansonia 11: 293 (1875); Engl., Monogr. Afr. Pfl. 1 (Moraceae) : 30 (1898); Hutch. in Prain, Fl. Trop. Afr. 6 (2) : 221 (1917). - Type species: S. manniana Baillon.

Cyathanthus Engl. in Engl. \& Prantl, Nat. Pflanzenfam., Nachtr. 1 : 120 (1897). - Type species : C. zenkeri Engl. (= S. manniana Baillon).

Small monoecious undershrubs with rhizomatous stems and ascending or erect leafy twigs. Leaves distichous, pinnately veined; stipules subamplexicaul, free. Inflorescences solitary to several together on short-shoots 
in the leaf axils, bisexual, cup-shaped to funnel-shaped, pedunculate, with 4 reniform, imbricate bracts on the margin of the receptacle; staminate flowers many, in several series, partly in small groups, pedicellate; perianth tubular, (3-)4(-5)-lobed to -fid; stamens 1-2(-3), straight before anthesis, anthers narrow, latrorse; pistillode lacking; pistillate flowers solitary in the centre of the receptacle, free; perianth with $2(-3)$ free or 4 connate tepals; ovary free, stigmas 2 . Fruit $\left({ }^{1}\right)$ free from the enlatged green perianth; exocarp white, fleshy, dehiscent, pushing the endocarp body; endocarp thin; testa $\left({ }^{1}\right)$ thin with a suborbicular thickened vascularized part below the small hilum; cotyledons (alsmost) equal, thick and fused, radicle subapical and short.

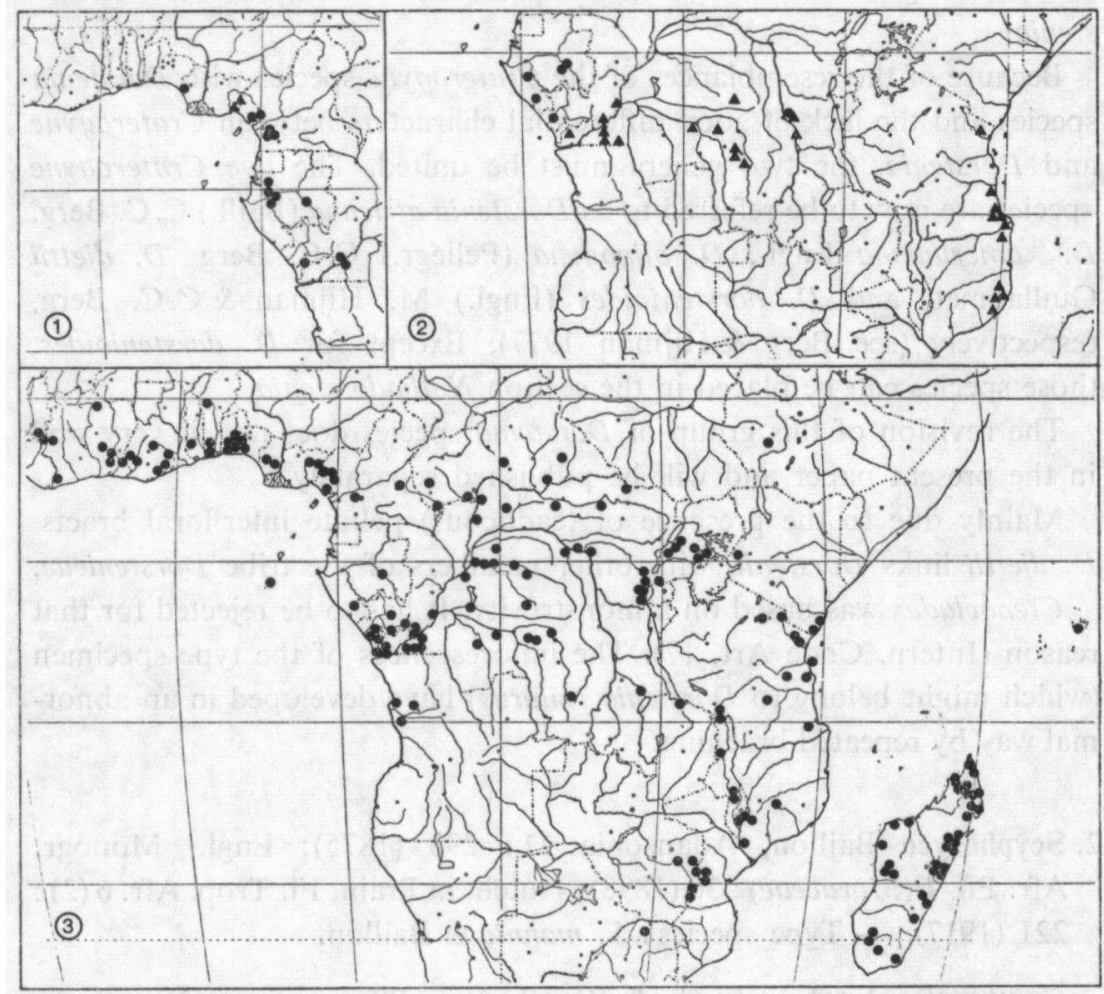

Fig. 1. - Distribution of species of the Dorstenieae: map 1, Scyphosyce manniana, $\Delta$ S. pandurata; map 2, Utsetela gabonensis, $\triangle$ Bosqueiopsis gilletii; map 3, Trilepisium madagascariense.

(1) Characters of fruit and seed only refer to $S$. manniana. 
Baillon (1875) founded the genus Scyphosyce by describing S. manniana. In 1897, Engler described Cyathanthus, but he soon (1898) recognized this genus as identical with Scyphosyce and transferred C. zenkeri to Scyphosyce. Two other species were added to the genus Scyphosyce: $S$. gilletii (De Wildeman \& Th. Durand 1903) and $S$. pandurata (Hutchinson 1917, 1919). Only the latter proved to be distinct from S. manniana.

The two species show interesting differences in the inflorescence. In $S$. manniana both the staminate flowers and the pistillate flower arise from the bottom of the cup-shaped to tunnel-shaped receptacle. At anthesis the staminate flowers are almost sessile but in fruit distinctly pedicellate. In $S$. pandurata the (apparently) sessile staminate flowers arise (apparently) from the middle of the funnel-shaped receptacle. However, the tissue surrounding the pistillate flower (which arises from the bottom of the receptacle) is probably formed by the fused pedicels of the staminate flowers. The perianth of staminate flowers of S. manniana consists of 2 free conduplicate tepals, sometimes accompanied by a reduced third one. In $S$. pandurata the perianth of the pistillate flower consists of 4 basally connate tepals.

In $S$. manniana the very thin testa coheres with the endocarp which looks like a testa.

In habit the Scyphosyce species call to mind several Dorstenia species.

Key to the species of Scyphosyce

1.a. Periderm of the twigs not peeling off; pistillate flower with 2(-3) free tepals;

S.E. Nigeria to Zaire . . . . . . . . . . . 1. S. manniana

b. Periderm of the twigs peeling off; pistillate flower with 4 connate tepals;

S.E. Nigeria . . . . . . . . . . . 2. S. pandurata

2.1. Scyphosyce manniana Baillon, Adansonia 11 : 293 (1875); Hutch. in Prain, Fl. Trop. Afr. 6 (2) : 221 (1917). - Type : Mann 1727, Gabon, Monts de Cristal (P; isotype K). - Fig. 2.

Cyathanthus zenkeri Engl. in Engl. \& Prantl, Nat. Pflanzenfam., Nachtr. 1 : 120 (1897). - Type: Zenker 905, Cameroun, near Bipinde (B; isotypes $\mathrm{G}, \mathrm{K}, \mathrm{P}$ ).

Scyphosyce zenkeri (Engl.) Engl., Monogr. Afr. Pfl. 1 (Moraceae): 31, t. 10 (1898). 
S. gilletii De Wild., Ann. Mus. Congo, Bot., ser. 5, 1 : 26 (1903); Hauman, Fl. Congo, Ruanda-Urundi 1 : 98 (1948). - Type: Gillet s.n., Zaire, near Kinshasa (BR).

Undershrubs up ca. $50 \mathrm{~cm}$ tall; leafy twigs sometimes branched, 1-4 mm thick, (rather) densely whitish to brownish hirtellous to puberulous with straight to curved hairs; periderm not peeling off. Leaves often crowded in the upper part of the twigs, elliptic to lanceolate, mostly broadly to narrowly obovate to subpandurate or oblanceolate, not or hardly inequilateral, (1.5-)5-18 cm long, (0.5-)2-7 cm broad, chartaceous, acuminate to subcaudate, at the base (sub)obtuse to subcordate, at least one half auriculate; margin entire or more or less distinctly crenate to (sometimes coarsely) dentate towards the apex; above (almost) glabrous beneath sparsely to rather densely puberulous to hirtellous (partly with uncinate hairs) especially on the main veins, sometimes almost glabrous; above veins slightly prominent to plane, beneath more or less prominent, 6-15 pairs of secondary veins, usually without parallel tertiary veins; petioles 2-12 mm long, (rather) densely hirtellous, with straight to curved hairs; stipules 2-15(-20) $\mathrm{mm}$ long, lanceolate to narrow-ovate, with a prominent costa, the apex mucronate to (sub)aristate, puberulous to almost glabrous, dark brown, subpersistent. Inflorescences solitary to several together, at least initially deflexed, $2-4 \mathrm{~mm}$ in diameter, cupshaped to funnel-shaped; bracts ciliolate; the 3-11 mm long peduncle and receptacle glabrous or with sparse appressed unicellular hairs and/or reddish globose-capitate pluricellular hairs, at the base of the peduncle usually a reniform to deltoid, mucronate, ciliolate bract; staminate flowers arising from the bottom of the receptacle, partly in groups of 2-3; perianth 1.5-2.5 mm high, (irregularly) (3-)4 (-5)-lobed to -fid, upper part puberulous or only ciliolate, pedicels up to ca. $4 \mathrm{~mm}$ long; stamens $1-2(-3)$, filaments $2-3 \mathrm{~mm}$ long, very sparsely to densely hairy, the upper part glabrous, anthers $(0.3-) 0.5-0.8 \mathrm{~mm}$ long, $0.15-0.3 \mathrm{~mm}$ broad, connective rather narrow, sometimes apiculate; pistillate flower sessile on the bottom of the receptacle; perianth $2-3 \mathrm{~mm}$ high, with 2 free, conduplicate, imbricate, sparsely puberulous to glabrous, ciliolate tepals, sometimes a third plane, lanceolate to narrowly ovate tepal; ovary ca. $1 \mathrm{~mm}$ high, style $2-3 \mathrm{~mm}$ long, sometimes puberulous, stigmas ca. $1.5 \mathrm{~mm}$ long, filiform to vittiform, minutely puberulous. Infructescences ca. $7 \mathrm{~mm}$ in diam.; fruiting perianth ca. $1-1.2 \mathrm{~cm}$ high, fruit ca. $8-10 \mathrm{~mm}$ long, endocarp body ca. 6-7 $\times 4-6 \mathrm{~mm}$, endocarp thin, brown to blackish (with a paler, reticulate venation somewhat rugose); testa thin, cohering 


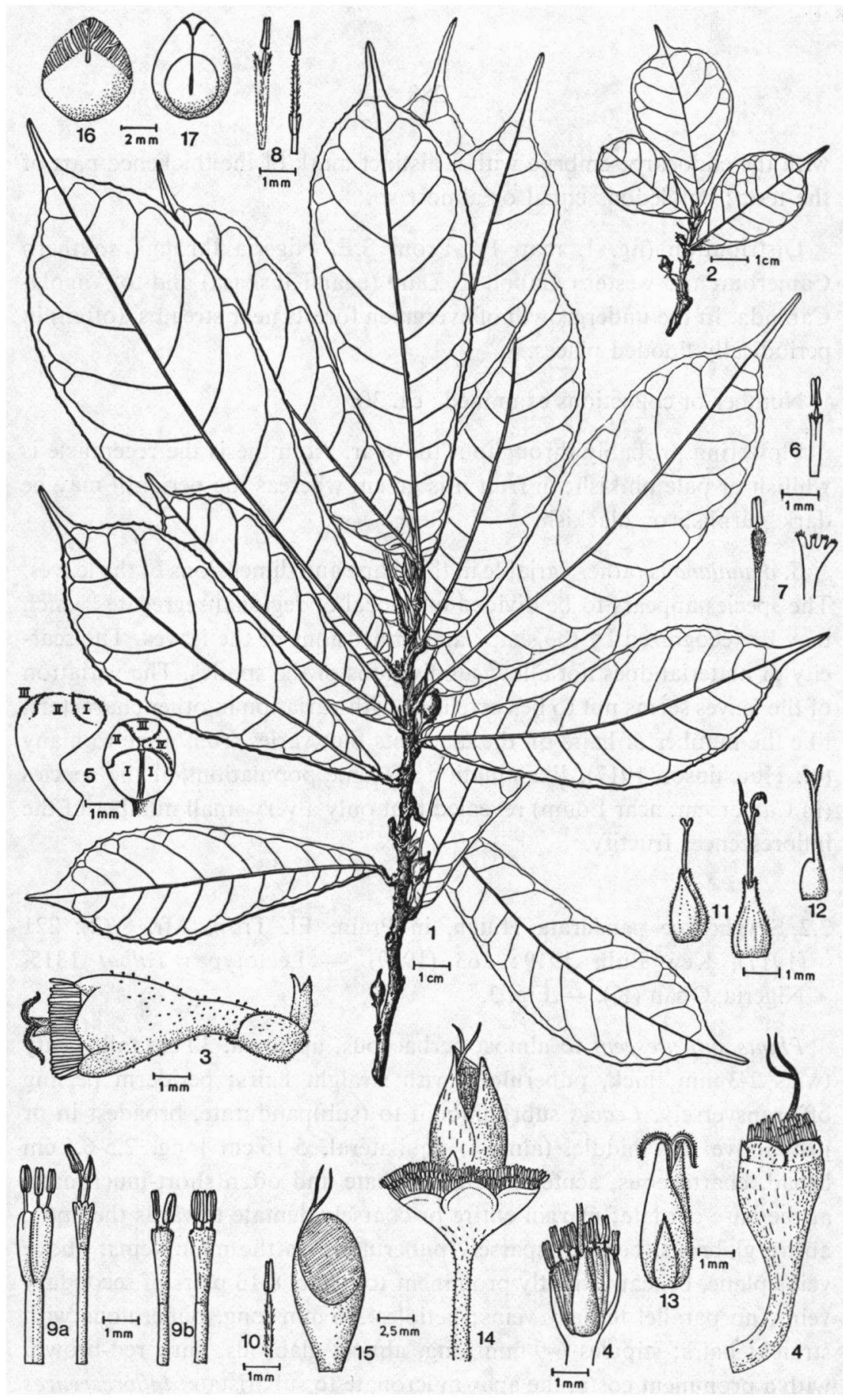

Fig. 2. - Scyphosyce manniana: 1, leafy twig with infructescences; 2, leafy twig with inflorescence and infructescence; $3 \& 4$, inflorescences; 5 , involucre; 6, staminate flower and stamen; 9a \& b, staminate flowers; 10 , stamen; 11 , pistillate flower; 12 , pistil; 13, pistillate flower; 14 , infructescence; 15 , fruit; 16 , seed; 17 , embryo. (1: Thollon 84; 2, 4-7: de Wit 8266; 3, 8, 13: Gossweiler 8141:9a \& b, 10, 14-17: Sitha $1938 \mathrm{a} ; 11,12$ : de Wit 398 or 8266$)$. 
with the endocarp; embryo with a distinct mark of the thickened part of the testa; cotyledons equal or almost so.

Distribution (fig. 1, map 1): From S.E. Nigeria through southern Cameroun and western Gabon to Zaire (near Kinshasa) and to AngolaCabinda. In the undergrowth of evergreen forests near streams, (often) in periodically flooded places.

Number of collections examined : ca. 30.

Flowering probably throughout the year. At anthesis the receptacle is whitish or pale pinkish; in fruit it is green, whereas the perianth may be dark purplish or blackish.

$S$. manniana is rather variable in the shape and dimensions of the leaves. The species appears to be divided into local or regional segregates which may be recognized by the shape and dimensions of the leaves. The scarcity of material does not allow subdivisions of the species. The variation of the leaves seems not to be correlated with variation in other characters, like the number of hairs on the filaments that varies from none to many (cf. Hutchinson 1917). Examination of some populations of the species (in Cameroun, near Loum) revealed that only a very small number of the inflorescences fructify.

2.2. Scyphosyce pandurata Hutch. in Prain, Fl. Trop. Afr. 6 (2): 221 (1917), Kew Bull. 1919: 263 (1919). - Lectotype: Talbot 1315, Nigeria, Oban (K). - Fig. 3.

Plants suffrutescent to almost herbaceous, up to ca. $30 \mathrm{~cm}$ tall. Leafy twigs 2-3 $\mathrm{mm}$ thick, puberulous with straight hairs; periderm peeling off transversely. Leaves subrhomboid to (sub)pandurate, broadest in or just above the middle, (almost) equilateral, $5-16 \mathrm{~cm}$ long, $2.5-6.5 \mathrm{~cm}$ broad, chartaceous, acute to subacuminate and often short-mucronate, at the base cordate; margin entire or coarsely dentate towards the apex; above glabrous, beneath sparsely puberulous on the main veins; above veins plane, beneath slightly prominent to plane, 8-13 pairs of secondary veins, no parallel tertiary veins; petioles $3-6 \mathrm{~mm}$ long, puberulous with straight hairs; stipules 6-9 mm long, almost glabrous, dark red-brown, with a prominent costa, the apex mucronate to subaristate. Inflorescences solitary, receptacle funnel-shaped, ca. $5 \mathrm{~mm}$ high, $3-4 \mathrm{~mm}$ in diam.; peduncle $0.5-1.5 \mathrm{~cm}$ long, peduncle and receptacle with sparse minute white unicellular hairs and less sparse reddish globose capitate pluricellu- 


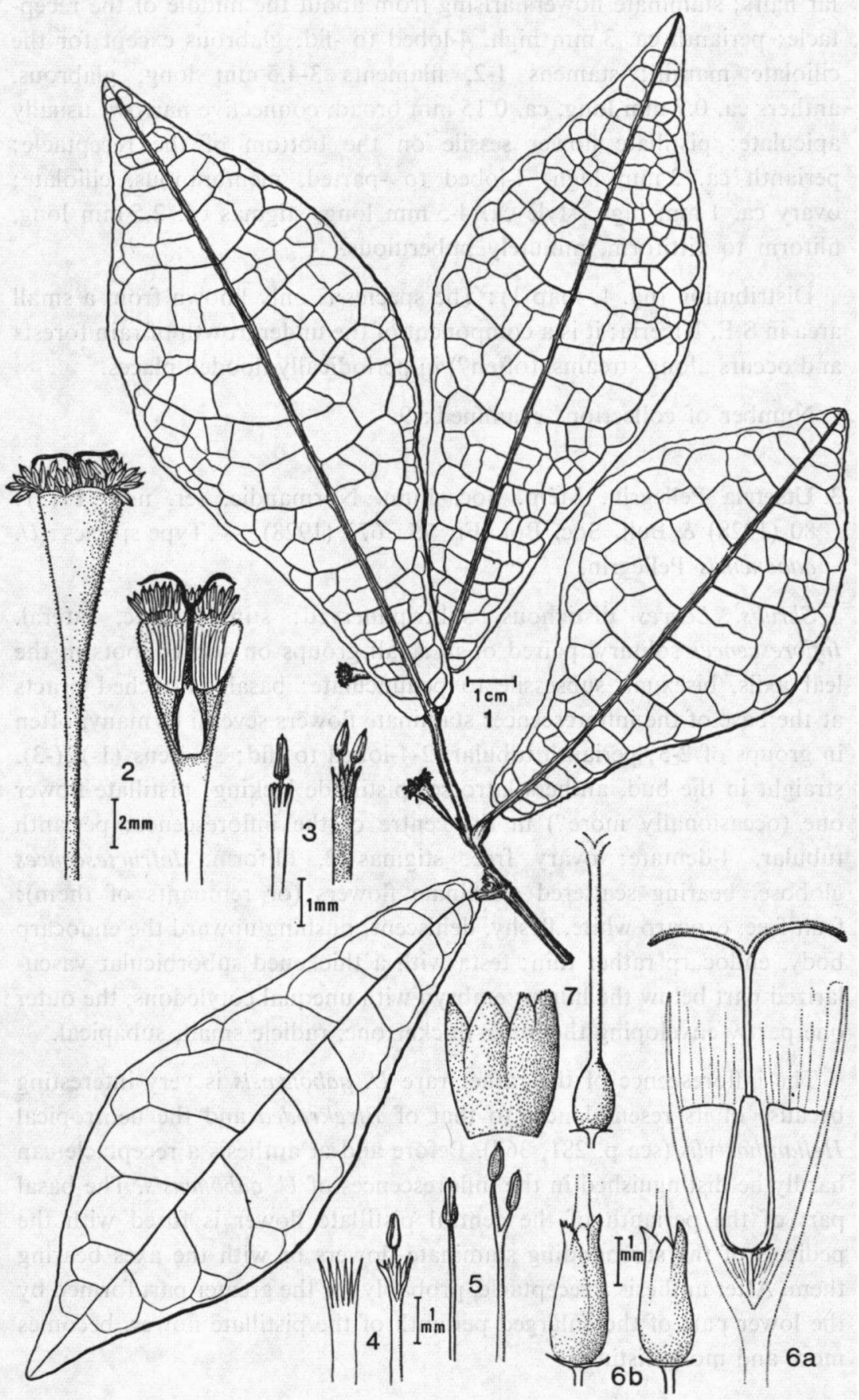

Fig. 3. - Scyphosyce pandurata: 1, leafy twig with inflorescences; 2, inflorescence; 3, staminate flowers; 4 , staminate flower and perianth; 5 , stamens; $6 a$ \& b, pistillate flower; 7, perianth and pistil (Latilo 45806). 
lar hairs; staminate flowers arising from about the middle of the receptacle; perianth ca. $3 \mathrm{~mm}$ high, 4-lobed to -fid, glabrous except for the ciliolate margin; stamens $1-2$, filaments $3-4.5 \mathrm{~mm}$ long, glabrous, anthers ca. $0.7 \mathrm{~mm}$ long, ca. $0.15 \mathrm{~mm}$ broad, connective narrow, usually apiculate; pistillate flower sessile on the bottom of the receptacle; perianth ca. $3 \mathrm{~mm}$ high, 4-lobed to -parted, membranous, ciliolate; ovary ca. $1 \mathrm{~mm}$ high, style ca. $4-5 \mathrm{~mm}$ long, stigmas ca. $2.5 \mathrm{~mm}$ long, filiform to vittiform, minutely puberulous.

Distribution (fig. 1, map 1): The species is only known from a small area in S.E. Nigeria; it is a component of the undergrowth of rain forests and occurs along streams, (often?) in periodically flooded places.

Number of collections examined : 9.

3. Utsetela Pellegrin, Mém. Soc. Linn. Normandie, ser. nov. 1 (3): 80 (1928) \& Bull. Soc. Bot. Fr. 75 : 673 (1928). - Type species : $U$. gabonensis Pellegrin.

Shrubs. Leaves distichous, subtriplinerved; stipules free, lateral. Inflorescences solitary, paired or in small groups on short-shoots in the leaf axils, bisexual, subsessile to pedunculate; basally attached bracts at the base of the inflorescence; staminate flowers several to many, often in groups of 2-3; perianth tubular, 2-4-lobed to -fid; stamens (1-)2(-3), straight in the bud, anthers latrorse; pistillode lacking; pistillate flower one (occasionally more?) in the centre of the inflorescence; perianth tubular, 4-dentate; ovary free, stigmas 2, filiform. Infructescences globose, bearing scattered staminate flowers (or remnants of them); fruit free, exocarp white, fleshy, dehiscent, pushing upward the endocarp body, endocarp rather thin; testa with a thickened suborbicular vascularized part below the hilum; embryo with unequal cotyledons, the outer one partly enveloping the inner thicker one, radicle small, subapical.

The inflorescence of the rather rare $U$. gabonensis is very interesting because of its resemblances to that of Bleekrodea and the neotropical Helianthostylis (see p. 281, 367). Before and at anthesis a receptacle can hardly be distinguished in the inflorescences of $U$. gabonensis. The basal part of the perianth of the central pistillate flower is fused with the pedicels of the surrounding staminate flowers or with the axes bearing them. After anthesis a receptacle, probably for the greater part formed by the lower part of the enlarged perianth of the pistillate flower, becomes more and more distinct. 
The infructescence is very similar to that of Helianthostylis (see Berg 1972a, 1972b). The young inflorescence is reminiscent of that of Bleekrodea. In Utsetela the fruit, with dehiscent exocarp, is free (as in Bleekrodea, but unlike Helianthostylis). The endocarp body is possibly released through a rift in the fruiting perianth (c.q. receptacle) as in Bleekrodea.

3.1. Utsetela gabonensis Pellegrin, Mém. Soc. Linn. Normandie, ser. nov. 1 (3): 81, t. 6 (1928) \& Bull. Soc. Bot. Fr. 75 : 673 (1928). - Type : Le Testu 1930, Gabon, near Tchibanga (P; isotypes B, BM, K). - Fig. 4.

Shrubs (branched or unbranched) up to $2.5 \mathrm{~m}$ (or more?) tall; latex white; leafy twigs $1-3.5 \mathrm{~mm}$ thick, puberulous with white to brown retrorse uncinate hairs. Leaves elliptic to lanceolate, mostly broadest in or above the middle, not or slightly inequilateral, (2-)3-19 cm long, $(0.5-) 1-8 \mathrm{~cm}$ broad, chartaceous, acuminate to caudate or to subacute, at the base acute to obtuse; margin (faintly) repand, more often coarsely dentate to lobed towards the apex; sparse hairs on the main veins and the margin; above the costa prominent, the other veins slightly prominent to plane or slightly impressed, beneath veins prominent, 3-8 pairs of secondary veins, the lower pair departing from the costa at an acute angle, the other pairs departing from the costa from about the lower third of the lamina upwards at less acute angles, without or with few parallel tertiary veins; stipules $2-5 \mathrm{~mm}$ long, ovate to deltoid, subaristate, with a prominent costa, sparsely puberulous, subpersistent. Inflorescences mostly solitary or paired, or sometimes more together in the leaf axils, 3-4 $\mathrm{mm}$ in diam.; peduncle up to $2 \mathrm{~mm}$ long, puberulous with straight and uncinate white to brownish hairs; perianth of the staminate flower 1-2 $\mathrm{mm}$ high, tubular, often more or less narrowed towards the base, irregularly 2-4-lobed to 2-4-fid, puberulous with partly uncinate hairs; stamens free or basally connate, filaments $1-4.5 \mathrm{~mm}$ long, slender, anthers $0.4-0.8(-1.0) \mathrm{mm}$ long, $0.2-0.5 \mathrm{~mm}$ broad, apiculate or not, connective rather broad; perianth of the pistillate flower ca. $3 \mathrm{~mm}$ long, puberulous with partly uncinate hairs; style 2-3 mm long, stigmas $1-4 \mathrm{~mm}$ long; bracts up to 7-8, in 2-3 series, with straight, relatively long, brownish, and uncinate, white to brownish hairs, the 3-4 outer ones deltoid to ovate, large (to ca. $3.5 \mathrm{~mm}$ long), the inner ones narrowly ovate to lanceolate or linear, usually much smaller. Infructescences (sub)globose, 6-9 $\mathrm{mm}$ in diam.; peduncle up to $3.5 \mathrm{~mm}$ long; receptacle densely puberu- 


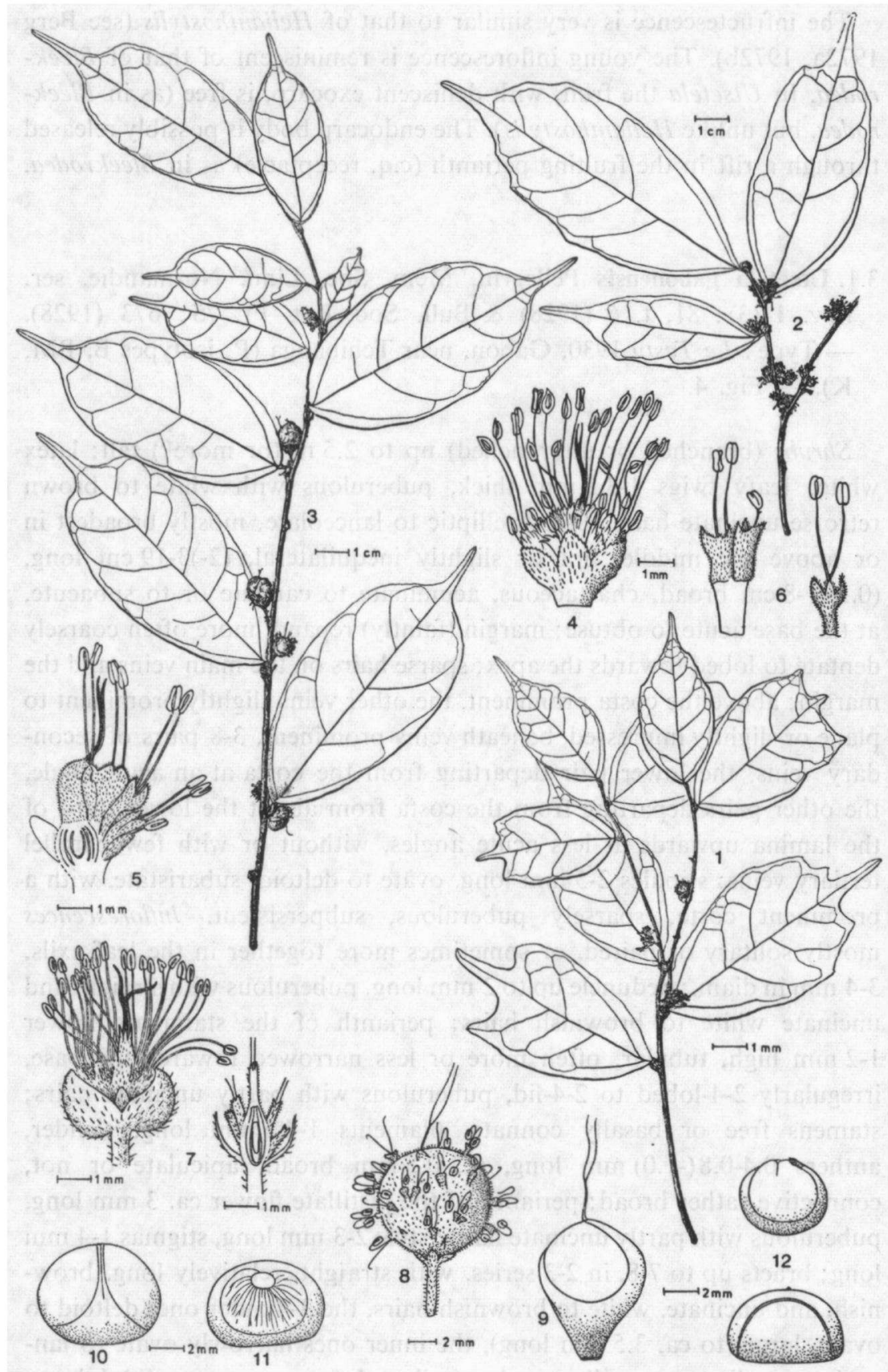

Fig. 4. - Utsetela gabonensis: 1 \& 2, leafy twigs with inflorescences; 3, leafy twig with infructescences; 4 , inflorescence; 5 , pistillate and staminate flowers; 6 , staminate flowers; 7 , inflorescence; 8 , infructescence; 9 , fruit; 10 , endocarp body; 11 , seed; 12 , embryo (1, 46: Le Testu 1930; 2: Le Testu 8012; 3, 8-12: Le Testu 5807; 7 : Lebrun 5879). 
lous with uncinate hairs; filaments in the persisting staminate flowers often reflexed; endocarp body ca. $8 \times 6-7 \mathrm{~mm}$; seed ca. $7 \times 5-6 \mathrm{~mm}$.

Distribution (fig. 1, map 2): Known from some localities in Gabon, a single locality in Congo (along the Lower Kouilou River, near Sounda), and a single locality in Zaire (Kivu, Terr. Panzi, Lumuna); in the undergrowth of forests.

Number of collections examined : 13.

Flowering probably throughout the year.

According to a field note of Le Testu 8012, the inflorescence may contain more than one pistillate flower.

4. Bosqueiopsis De Wild. \& Th. Dur., Bull. Herb. Boiss., ser. 2, 1 : 839 (1901); Engl., Bot. Jahrb. 51 : 435 (1914); Hutch. in Prain, Fl. Trop. Afr. 6 (2) : 217 (119); Hauman, Fl. Congo, Ruanda-Urundi 1 : 96 (1948). - Type species: B gilletii De Wild. \& Th. Dur.

Monoecious or (androdioecious?) shrubs or trees. Leaves distichous, subtriplinerved to pinnately veined; stipules free, subamplexicaul. Inflorescences bisexual or staminate, discoid to subglobose, usually pedunculate, with interfloral peltate bracts and 1-3 rows of imbricate basally attached marginal or subtending bracts; staminate flowers several to many; perianth 3-4-fid to 3-4-parted; stamens (1-)2, inflexed before anthesis, gradually straightening at anthesis, anthers latrorse; pistillode lacking; pistillate flower solitary, immersed in the centre of the receptacle and adnate to it; ovary adnate to the perianth; stigmas 2, vittiform. Infructescences with a yellow to orange fleshy receptacle; endocarp crustaceous; testa rather thick with a thickened, suborbicular, apical, not distinctly vascularized part; cotyledons unequal, thick, radicle very short, in a lateral pit of the embryo.

Four Bosqueiopsis species have been described and kept separated mainly on the basis of differences in the shape and dimensions of the leaves. These differences are not very distinct and cannot be used for disti nguishing taxa, not even on an infraspecific level.

On the other hand, differences in habit and habitat between groups of populations of the single species B. gilletii in Zaire and in East Africa, suggesting the presence of ecological differences, may prove to be constant 
and significant. At this moment, however, the scarcity of collections and the poor data given by the labels do not provide a sufficient basis for distinguishing subspecies. A subdivision on the basis of these characters should be made only after ample consideration, in view of the rather broad ecological amplitude of many arborescent African Moraceae (see p. 278, 279).

The distinctly inflexed stamens which gradually straighten out at anthesis, and the tendency to produce unisexual inflorescences are remarkable features of B. gilletii.

The name Trymatococcus parvifolius was probably erroneously published by Engler (1915) together with the drawing which also accompanied the description of Bosqueiopsis parvifolia Engler (1914).

The bisexual inflorescences and infructescences of Bosqueiopsis resemble those of the neotropical genus Trymatococcus.

4.1. Bosqueiopsis gilletii De Wild. \& Th. Dur., Bull. Herb. Boiss., ser. 2, 1 : 840 (1901); Engl., Bot. Jahrb. 51 : 435, t. 2 (1914). - Type : Gillet 1742, Zaire, Kimuenza (BR). - Fig. 5.

B. lujae De Wild., Pl. Nov. Herb. Hort. Then. 1 (7): 239, t. $56(1907)$. - Type : Luja 78, Zaire, Sankuru River (BR).

B. carvalhoana Engl., Bot. Jahrb. 51 : 436, t. 3 (1914). - Type : de Carvalho s.n., Moçambique (COI; isotype B).

B. parvifolia Engl., Bot. Jahrb. 51 : 437, t. 4 (1914). - Type Koerner 2259, Tanzania, Amani (B).

Trymatococcus parvifolius Engl., Pflanzenw. Afr. 3 (1): 27, t. 15 (1915), without description, plate based on Koerner 2259.

Shrubs or trees up to $25 \mathrm{~m}$ tall; latex white to yellowish or greyish, Leafy twigs $1-3(-5) \mathrm{mm}$ thick, sparsely to densely puberulous with retrorse, uncinate or curved hairs. Leaves (elliptic to) oblong to lanceolate, mostly tending to obovate or oblanceolate, distinctly to hardly inequilateral, (1-)2-14(-21) cm long, (0.7-) $1.5-6(-12.5) \mathrm{cm}$ broad, chartaceous to subcoriaceous, acuminate, at the base acute to obtuse; margin entire; above almost glabrous, beneath on the veins puberulous with uncinate hairs; above veins slightly prominent to plane, beneath especially the main veins prominent, 3-6 pairs of secondary veins, the basal pair departing from the costa at an acute angle, the others (often not distinctly paired) departing from the costa from about the middle of the lamina upwards, at less acute angles, without parallel tertiary veins; petioles 

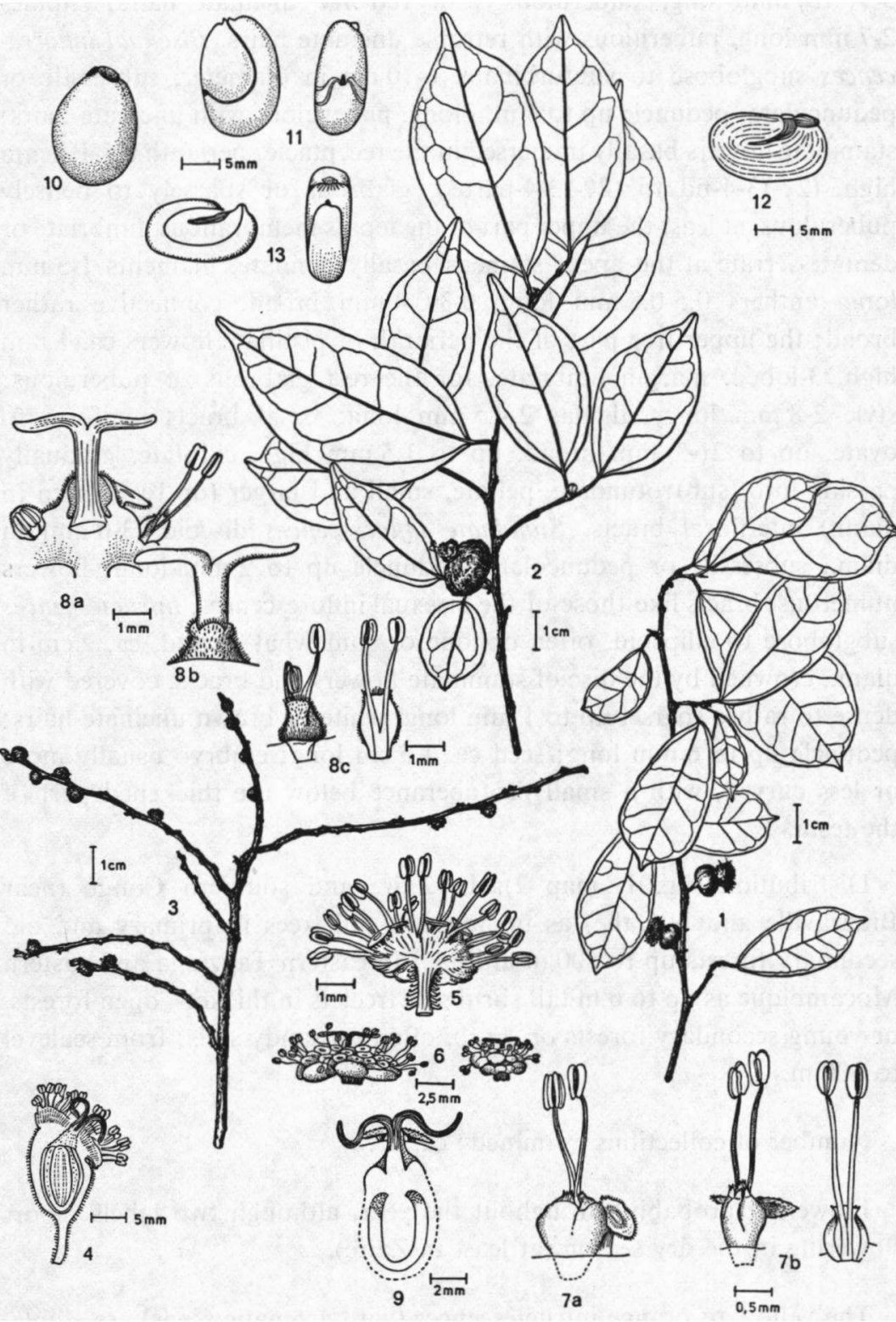

Fig. 5. - Bosqueiopsis gilletii: 1, leafy twig with inflorescences; 2 . leafy twig with infructescence; 3 , leafless twig with staminate inflorescences; 4 , bisexual inflorescence; 5 , staminate inflorescence; 6 , staminate inflorescences with abortive pistillate flower; $7 \mathrm{a} \& \mathrm{~b}$, staminate flowers and bracts; 8a, b \& c, abortive pistillate flower and staminate flowers; 9 , pistillate flower; 10 , seed; 11 , embryo; 12 , seed; 13 , embryo (1, 2 : Carlier 272; 3 : Schlieben 5437; 4, 5, 7a \& b, 9: Gillett 17956; 6, 8a, b \& c: Collin 17; 10, 11 : Torre \& Paiva 10051 ; 12, 13 : s. coll. s.n.). 
3-9(-15) $\mathrm{mm}$ long, puberulous with retrorse uncinate hairs; stipules 2-7 $\mathrm{mm}$ long, puberulous with retrorse uncinate hairs. Bisexual inflorescences subglobose to subturbinate, $6-10 \mathrm{~cm}$ in diameter, subsessile or pedunculate; peduncle up to $4 \mathrm{~mm}$ long, puberulous with uncinate hairs; staminate flowers basally immersed in the receptacle; perianth $0.5-1.5 \mathrm{~mm}$ high, (2?-)3-4-fid to (2?-)3-4-parted, glabrous or sparsely to densely puberulous, at least the upper part of the tepals membranous, fimbriate or dentate-serrate at the apex; stamens basally connate, filaments $1-3 \mathrm{~mm}$ long, anthers $0.5-0.8 \mathrm{~mm}$ long, $0.3-0.4 \mathrm{~mm}$ broad, connective rather broad; the upper free part of the perianth of pistillate flowers ca. $1 \mathrm{~mm}$ high, 3-lobed, margin fimbriate, for the rest glabrous or puberulous; style $2-8 \mathrm{~mm}$ long, stigmas $2-4.5 \mathrm{~mm}$ long; basal bracts reniform to ovate, up to $2(-3) \mathrm{mm}$ broad, up to $1.5 \mathrm{~mm}$ high, ciliolate, gradually passing into (sub)rotundate, peltate, small and larger (up to $1.5 \mathrm{~mm}$ in diam.) interfloral bracts. Staminate inflorescences discoid, $3-6 \mathrm{~mm}$ in diam., subsessile or pedunculate; peduncle up to $2 \mathrm{~mm}$ long; flowers numerous; bracts like those of the bisexual inflorescences. Infructescences subglobose to ellipsoid, often oblique or somewhat curved, ca. $2 \mathrm{~cm}$ in diam., crowned by the disc of staminate flowers and bracts, covered with dense to rather sparse, up to $1 \mathrm{~mm}$ long, white or brown uncinate hairs; peduncle up to $6 \mathrm{~mm}$ long; seed ca. $1.5 \mathrm{~cm}$ long; embryo usually more or less curved, with a small protuberance below the thickened part of the testa.

Distribution (fig. 1, map 2). In Zaire and southern Congo (near Brazzaville and N'Gabé) as up to $35 \mathrm{~m}$ tall trees in primary and old secondary forests up to $500 \mathrm{~m}$ altitude; in eastern Tanzania and eastern Moçambique as up to $6 \mathrm{~m}$ tall shrubs or treelets in thickets, open forests, or young secondary forests or scrub, often on sandy soils; from sealevel to $500 \mathrm{~m}$.

Number of collections examined : ca. 45.

Flowering probably throughout the year, although two labels report flowering in the dry season (at least in Zaire).

The yellow to orange infructescences (with aromatic seeds) are edible. The wood is used for carpentry.

In some of the collections staminate inflorescences were found. These discoid inflorescences may have a central abortive pistillate flower with 
more or less well-developed style and stigmas. On the basis of the available herbarium material it is not possible to ascertain if bisexual and staminate inflorescences are borne on separate trees or on the same tree.

5. Trilepisium Thouars, Gen. Nov. Madag. : 22 (1806); DC., Prodr. 2: 639 (1825); Benth. \& Hook., Gen. Pl. 1 (2): 605 (1865). Proposal Bosqueia versus Trilepisium: Taxon 17: 731 (1968), 19: 293 (1970), and 24 : 239 (1975). - Type species : Trilepisium madagascariense DC.

Bosqueia Thouars ex Baillon, Adansonia 3: 338 (1863); Benth. \& Hook., Gen. Pl. 3(1) : 379 (1880); Engl., Monogr. Afr. Pfl. 1 (Moraceae): 35 (1898); De Wild. \& Th. Dur., Bull. Herb. Boiss., ser. 2, 1 : 839 (1901); Hutch. in Prain, Fl. Trop. Afr. 6(2) : 218 (1917); Léandri, Not. Syst. 13: 176 (1948). - Lectotype species : B. thouarsiana Baillon (= Trilepisium madagascariense DC.); see Capuron, Taxon 17 : 732 (1968).

Bosquiea Benth. \& Hook., Gen. Pl. 3(1): 370 (1880).

Pontya A. Chev., Végét. Ut. Afr. Trop. Fr. 5 : 263 (1909), nomen; Bull. Soc. Bot. Fr. 58 (Mém. 8a) : 210 (1912); Hutch. in Prain, Fl. Trop. Afr. 6(2): 219 (1917). - Type species : P. excelsa A. Chev. (= Trilepisium madagascariense $\mathrm{DC}$.).

Monoecious trees. Leaves distichous, pinnately veined to subtriplinerved; stipules fused, fully amplexicaul. Inflorescences solitary or sometimes in pairs on short shoots in the axils of leaves, initially enveloped by two modified stipules, bisexual, discoid to turbinate, pedunculate, with a 6-8-lobed to -fid submembranaceous involucre, the upper part of the receptacle submembranous, bent inwards and with its margin fused with the inner surface of the receptacle, covering many free stamens, at anthesis circumscissile and leaving a tubular and torn part aouund the perianth of the single central pistillate flower and a marginal and torn part; anthers latrorse; pistillate flower basally embedded in the receptacle, perianth tubular; ovary adnate to the perianth; stigmas 2, vittiform. Infructescences oblongoid to globose, crowned by the remains of the submembranous part of the receptacle and the stamens, the receptacle fleshy, red to blackish; endocarp crustaceous; testa rather thin, with a thickened suborbicular vascularized part below the hilum; embryo with a distinct mark of this part of the testa; cotyledons thick, equal and fused, radicle short, apical or subapical. 
The genus Trilepisium was described by Du Petit-Thouars (1806) and placed in the Rosaceae. De Candolle (1825) published the epithet madagascariense and regarded the genus as related to the Rosaceae. From this family Trilepisium was definitely excluded by Bentham \& Hooker (1865) and henceforth almost neglected, until Capuron (1968) recognized it as identical with the genus Bosqueia, established by Baillon (1863), which genus was even partly based on material having served for the description of Trilepisium. Capuron's finding resulted in a proposal to conserve the name Bosqueia. This proposal was not carried (cf. Taxon 19 : 293.1970 and $24: 239$. 1975).

Within Bosqueia 13 species have been described. From material of this genus Chevalier (1912) described the new genus Pontya with $P$. excelsa as the sole species. All the described species prove to belong to the resurrected $T$. madagascariense. In spite of the considerable variation, no infra-specific taxa with a sound basis can be distinguished.

Because of the highly evolved inflorescence Trilepisium occupies a rather isolated position within the Dorstenieae.

Inflorescence: The peculiar inflorescences of Trilepisium are borne on short-shoots in the axils of the leaves. Two modified and more or less differently shaped coriaceous stipules form the scales of the bud, enclosing the single young, laterally compressed inflorescence and often a minute leaf which belongs to the upper stipule. The short-shoot may develop into a normal shoot. At anthesis the inflorescence appears from between the scale-like stipules and points downwards. It soon becomes discoid to broadly turbinate. The inflorescence has a central pistillate flower, basally embedded in the receptacle and a ring of stamens of the perianthless staminate flowers in several rows. Before anthesis the stamens are completely covered by a membranous structure bending over the stamens from the margin of the receptacle to near the base of the free part of the perianth of the pistillate flower. At anthesis this membrane tears all round and leaves a tubular to more or less infundibuliform, irregularly torn part around the perianth of the pistillate flower and a marginal, also irregularly torn part. The membranous structure probably represents the enlarged peripheral part of the receptacle (occurring in some Dorstenia species). Its slightly thickened margin is adnate to the inner rim of the stamen-bearing part of the receptacle. The inflorescence has a (sometimes) irregularly 6-8-lobed to -fid involucre, quite separate from the stamencovering membranous structure. The present interpretation of the structure of the inflorescence of Trilepisium has to be tested by an ana- 
tomical study for which well-preserved young inflorescences are required.

The way in which the young stamens are protected is rather complicated, the evidently not very effective protection by the (too weak) enlarged margin of the receptacle is supplemented by the more effective protection provided by the firm, modified stipules.

Bosquiea spinosa excluded: B. spinosa Engl., Bot. Jahrb. 40 : 548 (1908) \& Pflanzenw. Afr. 3(1): 33 (1915). It proved to belong to the Ulmaceous genus Chaetacme. Rendle [in Prain, Fl. Trop. Afr. 6(2): 14. 1916] put this species into the synonomy of Chaetacme microcarpa Rendle. Afterwards it is found in the synonomy of Chaetacme aristata Planchon, see Fl. Trop. W. Afr., ed. 2, 1: 593 (1958); Letouzey, Fl. Cameroun 8: 57 (1968).

5.1. Trilepisium madagascariense DC., Prodr. 2: 639 (1825). - Type: Du Petit-Thouars s.n., Madagascar (P). - Fig. 6 and 7.

Bosqueia thouarsiana Baillon, Adansonia 3: 339, t. 10 (1863); H. Perrier \& Léandri in Humbert, Fl. Madag. Moraceae : 34, t. 7 (1952). - Type : Du Petit-Thouars s.n., Madagascar (P); very probably belonging to the same collection as the type of $T$. madagascariense.

B. thouarsiana var. acuminata Baillon, 'Adansonia 3: 339 (1863). Based on the same type as the species.

B. thouarsiana var. pyriformis Baillon, Adansonia 3: 339 (1863); Léandri, Not. Syst. 13 : 179 (1948). — Type : Boivin s.n., Madagascar, Nossi Bé (P).

B. boiviniana Baillon, Adansonia 3: 340, t. 10 (1863); Léandri, Not. Syst. 13 : 179 (1948); H. Perrier \& Léandri in Humbert, Fl. Madag. Moraceae: 36, t. 7 (1952). - Type: Boivin s.n. (comm. Richard), Madagascar, Nossi Bé (P).

B. phoberos Baillon, Adansonia 8: 72, t. 4 (1867); Aubrév., Fl. For. Côte d'Ivoire 1 : 68 (1958). - Type : Boivin s.n., Tanzania, Zanzibar (P; isotypes $\mathrm{BM}, \mathrm{K})$.

B. angolensis Ficalho, Pl. Ut. Afr. Port. : 27 (1884); De Wild. \& Th. Dur., Bull. Herb. Boiss., ser. 2., 1 : 839 (1901). - Type : Welwitsch 456, Angola, Golungo Alto, near Sange (B, BM, G, K, LISU, P; the specimen in LISU probably served for the description of $B$. angolensis, that in $B$ for the description of B. welwitschii). 

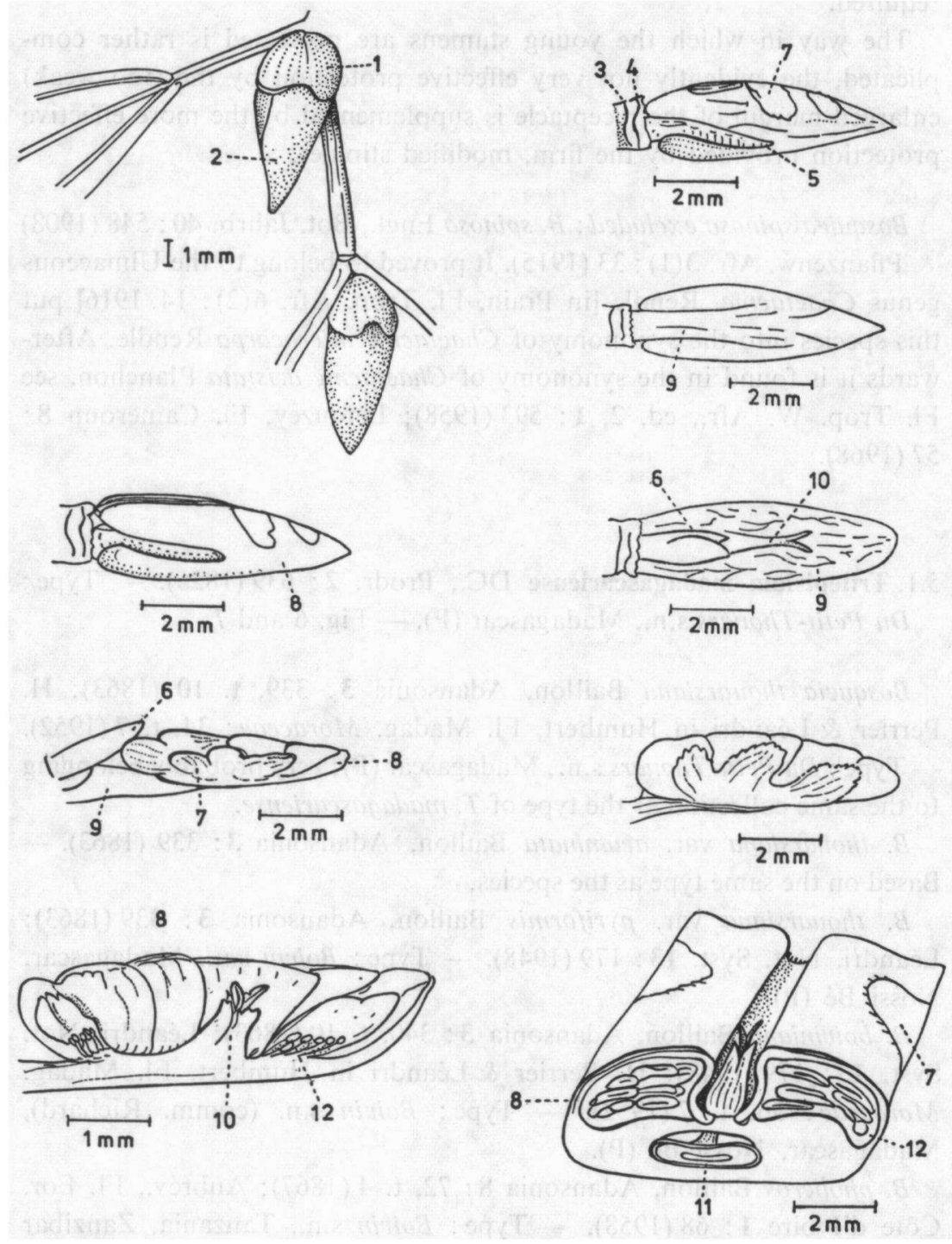

Fig. 6. - Young inflorescence of Trilepisium madagascariense: 1, lower bud scale (= fused, modified stipules); 2 , upper bud scale (= fused, modified stipules); $3 \& 4$, scars of bud scales; 5 , reduced leaf; 6 , shoot apex; 7 , involucre; 8 , expended margin of the receptacle; 9, peduncle; 10, pistillate flower; 11, ovary; 12, stamens (Garcia 886). 
B. welwitschii Engl., Monogr. Afr. Pfl. 1 (Moraceae): 36 (1898); Engl., Bot. Jahrb. 51 : 439, t. 5 (1914); Hutch. in Prain, Fl. Trop. Afr. 6(2): 218 (1917).

Centrogyne angolensis Welw., herbarium label, name published by Benth. \& Hook., Gen. Pl. 3(1): 370 (1880).

Bosqueia gymnandra J. G. Baker, Fl. Mauritius Seychelles: 283 (1877). - Type: Horne 417, Seychelles (K).

B. cerasifolia Volkens ex Engl., Monogr. Afr. Pfl. 1(Moraceae): 36 (1898); Engl., Bot. Jahrb. 51 : 439, t. 5 (1914); Hutch. in Prain, Fl. Trop. Afr. 6(2) : 219 (1917). - Type: Volkens 1935, Tanzania, Kilimanjaro region (B; isotypes BM, BR, G).

B. carvalhoana Engl., Pflanzenw. Afr. 3(1): 33 (1915), nomen subnud. B. danguyana Léandri, Not. Syst. 13 : 178 (1948); H. Perrier \& Léandri in Humbert, Fl. Madag. Moraceae: 35, t. 7 (1952). - Lectotype : Perrier de la Bâthie 9956, Madagascar, Analamazaotra (P).

B. calcicola Léandri, Not. Syst. 13 : 179 (1948); Perrier de la Bâthie \& Léandri in Humbert, Fl. Madag. Moraceae : 35, t. 7 (1952). - Type : Perrier de la Bâthie 9841, Madagascar, Tsingy-mavo, near Ampandrano, on the Ranobe River (P).

B. orientalis Léandri, Not. Syst. 13 : 180 (1948); H. Perrier \& Léandri in Humbert, Fl. Madag. Moraceae : 38, t. 7 (1952). - Type : Perrier de la Bâthie 9898, Madagascar, between Fénérive and Lake Aloatra (P).

B. manongarivensis Léandri, Not. Syst. 13: 180 (1948); H. Perrier \& Léandri in Humbert, Fl. Madag. Moraceae : 38 (1952). - Type : Perrier de la Bâthie 2321, at the base of Massif of Manongarivo, along the Sambirano River (P).

B. occidentalis Léandri, Not. Syst. 13 : 181 (1948); H. Perrier \& Léandri in Humbert, Fl. Madag. Moraceae : 39, t. 7 (1952). - Type : Perrier de la Bâthie 1382, Madagascar, near Ankirihitra (P).

Pontya excelsa A. Chev., Végét. Ut. Afr. Trop. Fr. 5 : 263 (1909), nomen; Bull. Soc. Bot. Fr. 58(Mém. 8d) : 210 (1912), descr.; Hutch. in Prain, Fl. Trop. Afr. 6(2): 219 (1917). - Lectotype : Chevalier 20990, Guinea, between Lola and N'ZO (P; isotypes B, BR).

Trees, mostly up to $20-25 \mathrm{~m}$, sometimes up to $40 \mathrm{~m}$ tall; latex white, turning red or brownish; leafy twigs (0.5-)1-4 mm thick, usually glabrous, sometimes with sparse minute uncinate hairs. Leaves elliptic to oblong to lanceolate, sometimes subrotundate, broadest in or often above the middle and then to broadly or narrowly obovate or oblanceolate, (1-)2-12(-18) cm long, (0.5-)1.5-6.5(-8) cm broad, coriaceous to subcoriaceous, usually 


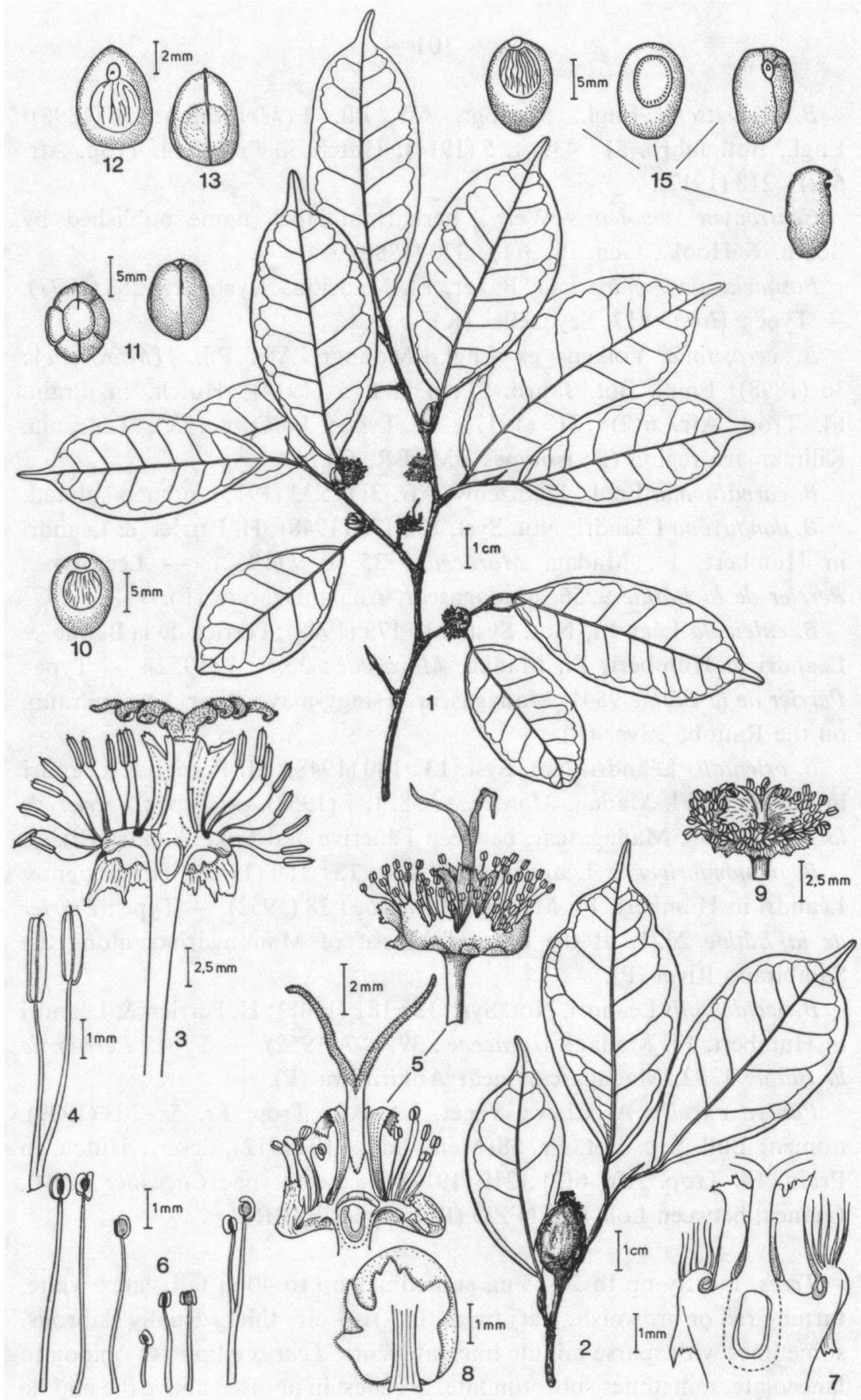

Fig. 7. - Trilepisium madagascariense : 1 , leafy twig inflorescences; 2 , leafy twig with infructescence; 3 , inflorescence; 4 , stamens; 5 , inflorescence; 6 , stamens; 7 , inflorescence; 8 , involucre; 9 , inflorescence; 10 , seed; 11 , embryo; 12 , seed; 13 , embryo; 14 , seed, 15, embryo (1, 2, 10, 11 : Breteler 2732; 3, 4: Gossweiler 4394; 5, 6 : Simao 506; 7, 8: Gossweiler 6514; 9 : Mendonça 141; 12, 13: Capuron 948; 14, 15: Devred 2454). 
shortly or long-acuminate, sometimes subcaudate, subacute, obtuse or emarginate, at the base acute to obtuse, often subauriculate; margin entire, rarely near the base incised to near the costa; glabrous on both sides, beneath often with minute oblongoid-capitate white pluricellular hairs; above veins slightly prominent to plane, the costa sometimes slightly impressed, beneath the costa prominent, the other veins less prominent to plane, 4-10(-12) pairs of secondary veins, the basal pair of secondary veins often distinct, often departing from the costa at more acute angles than the other secondary veins, without parallel tertiary veins; petioles 3-15 mm long; stipules 2-12 mm long, coriaceous, glabrous or sometimes with sparse minute uncinate hairs and/or ciliolate. Inflorescences (2-) 5-8(-10) $\mathrm{mm}$ in diam.; peduncle 2-12 $\mathrm{mm}$ long; receptacle and peduncle glabrous or sometimes with sparse uncinate hairs; involucre glabrous or with sparse uncinate hairs and/or ciliolate; stamens many, often 2 or more basally connate, filaments $(0.5-) 10 \mathrm{~mm}$ long, anthers ca. $0.3-2.0 \mathrm{~mm}$ long, ca. $0.3-0.6 \mathrm{~mm}$ broad, especially the longer ones often apiculate; occasionally 2 pistillate flowers; perianth $1.5-3 \mathrm{~mm}$ high, 4-lobed or irregularly incised to fimbriate, ciliolate; style (1-)2-9 mm long, stigmas $2-8 \mathrm{~mm}$ long, straight or twisted. Infructescences often slightly oblique or curved, ca. 0.8-2.5(-3) cm long, ca. $0.15-1.5(-2.5) \mathrm{cm}$ in diam.; receptacle glabrous or with sparse hairs, fleshy; peduncle up to $20(-30)$ $\mathrm{mm}$ long; seed ellipsoid to subglobose, ca. 6-16 mm long, ca. 4-14 mm broad.

Distribution (fig. 1, map 3): From Guinea to Angola and trough Zaire, the Central African Republic, and Uganda to S. Kenia, from there southwards to northern Natal (Republic of South Africa); besides in S. Ethiopia, in Annobon, Madagascar, and the Seychelles, according to Horne (coll. 417) on all islands, but not common. On the continent as evergreen trees in primary or secondary forests in regions with evergreen or semi-deciduous forests, often along streams, also in montane forests up to 2000(-2500?) m altitude; rare, frequent, or dominant. In Madagascar widely distributed, mostly as evergreen trees in wet to dry forests, on various soils, from sealevel to $1300 \mathrm{~m}$.

Number of collections examined : ca. 330 (African continent), ca. 100 (Madagascar), 5 (Seychelles).

In the whole area flowering throughout the year, with tops at the beginning and the end of the year; probable regional differences in (main) 
flowering times could not be established because of the scarce data available.

The stamens (and involucre) are purple. McWhriter (coll. 228) reported that the inflorescences have a pleasant scent.

The wood can be used for construction. The fruits (seeds) are locally eaten. The latex turning red is tinctorial.

The trees of $T$. madagascariense are mostly small or medium-sized. They may reach a height of $40 \mathrm{~m}$. These tall trees possibly occur more frequently at higher elevations (montane forests). In dry habitats (in Madagascar) the habit may be shrub-like. The trees are evergreen, but may periodically shed their leaves in dry habitats (Madagascar). They are occasionally epiphytic when young and strangling when older (Leeuwenberg 9511, Cameroun, near Nkongsamba).

The data from labels do not give certainty about the colour of the infructescences at full maturity. The infructescence turns from green to yellow, brownish or reddish. As a rule it finally turns blackish or dark purple, but it may retain a yellow or reddish to blood-red colour, even at full maturity. In the mature infructescence there is a mealy layer between the coloured outer layer of the receptacle and the endocarp.

$T$. madagascariense is very variable in leaf characters, dimensions of floral parts, and the shape and dimensions of the infructescence. On the African continent the species is rather uniform in its leaf characters. The lamina is usually elliptic to oblong or broadly ovate and more or less distinctly subtriplinerved. On the average the leaves are narrower in East Africa. A more pronounced difference between the representatives of the species in East Africa and in Central and West Africa is found in the length of the anthers. In the former area it varies from $0.3-1.0 \mathrm{~mm}$. In the south-western part of the area (from S.E. Kenia to Natal) the anthers are ca. $0.3-0.5 \mathrm{~mm}$ long. In Uganda and the adjacent parts of Tanzania, Kenia, and Zaire the anthers usually are somewhat longer $(8.5-1.0 \mathrm{~mm})$. From central Zaire westwards the anthers mostly have a length of 1-2 mm, although specimens with shorter stamens may (regionally) occur. The increase of the length of the anthers from East to West appears to be continuous, and the differences in length cannot serve for distinguishing infra-specific taxa. The differences in the shape and dimensions of the infructescences seem to be distributed at random.

In contrast to the continental representatives of the species the Madagascar ones show considerable variation in the leaf characters. The 
differences in the leaves cannot be correlated with other morphological differences. As on the continent, the floral parts and the infructescences show much variation. The length of the anthers varies from 0.5 to $1.5 \mathrm{~mm}$. Whereas the twigs of the continental specimens are (always?) glabrous, the Madagascan ones may bear sparse short uncinate hairs. But as a whole the Madagascan representatives of $T$. madagascariense cannot be satisfactorily distinguished from the continental ones, nor these two groups from the specimens from the Seychelles.

The difference in variation between the continental and the Madagascan representatives may be considered as an argument for subdividing the species, but this serves no purpose, unlike in Treculia africana, where regional differentiation justifies to distinguish infra-specific taxa for Madagascar.

In the material collected in Madagascar three groups of specimens can be distinguished on the basis of differences in leaf characters. They are, however, connected by intermediate forms. The variation in the shape, dimensions, and the texture of the leaves may be partly caused by differences in habitat, especially with regard to exposure and humidity conditions. But the variation does not appear to be related to area, altitude, soil, etc.

\section{Group A}

Leaves (rigidly) coriaceous, tending to obovate or oblanceolate, sometimes suborbicular, the apex obtuse, very shortly acuminate, or emarginate, the base usually acute, the basal pair of secondary veins usually not distinct. Fruit longer or shorter than $10 \mathrm{~cm}$.

This group comprises about $30 \%$ of the collections, among wich several showing resemblances to those of group $\mathrm{C}$, like the lectotype collection of Bosqueia danguyana.

Collections: e.g., Capuron 948, 8626, 8704, 8795, 9012, 9128, 10564, 11420, 11474, 20574, 27131, 27696; Service Forestier Madagascar 2866, 2918, 12581, 15105, 15117, 16538,16930 .

\section{Group B}

Leaves large, coriaceous, many of them longer than $10 \mathrm{~cm}$, the apex mostly long-acuminate, the base often obtuse, the basal pair of secondary veins not distinct. Fruit over $10 \mathrm{~cm}$ long. 
This group comprises about $10 \%$ of the collections, among which the type collections of $B$. orientalis and $B$. manongarivensis. A few collections ranked in this group somewhat resemble those of group $C$. The material of this group in leaf characters resembles the collections from the Seychelles.

Collections: e.g., Capuron 9152, 20345; Humbert \& Capuron 23985; Perrier de la Bâthie 2321, 9898; Service Forestier Madagascar 14508.

\title{
Group C
}

Leaves variable in shape, small or medium-sized, subcoriaceous to coriaceous, the apex long or shortly acuminate, the base acute or obtuse, the basal pair of secondary veins distinct or not. Fruit shorter or longer then $10 \mathrm{~cm}$.

This group, the most variable and the least clear-cut of the three, comprises about $60 \%$ of the collections, among which the type collections of $B$. thouarsiana, B. boiviniana, B. calcicola, and $B$. occidentalis. Several of the collections (e.g., Capuron 11306, 28146; Humbert \& Capuron 24575; Perrier de la Bâthie 9956) placed in this group approach those of group A, a few (e.g., Capuron 18209, Service Forestier Madagascar 19054) those of group B.

Collections: e.g., Boivin s.n.; Capuron 1000, 6767, 6772, 8647, 8718, 9006, 9101, 11509, 11661, 27333, 28355; Perrier de la Bathie 1133, 1382, 2193, 9841, 9931, 9960, 10006, 15420, 17439; Service Forestier Madagascar 2844, 5388, 5396, 5404, 8050, $10646,12622,12716,12836,13032,13262,16850,19312,19373$.

\author{
Castilleae C.C. Berg \\ Acta Bot. Neerl. 26 : 78 (1977)
}

Trees or shrubs, (always?) with spirally arranged self-pruning branches bearing the leaves in two rows; stipules rarely connate; uncinate hairs lacking; latex bitter, white or yellowish, usually turning pinkish or brown; wood fibers usually septate; cardiac glycosides present in several genera. Inflorescences mostly in groups on short-shoots in the leaf axils, unisexual, usually discoid, with an involucre of imbricate, basally attached bracts; perianth if present and well-developed (usually) with imbricate tepals; stamens usually straight; pistillodes rare; pistil mostly more or less adnate to the perianth. Fruit adnate to the perianth; seeds large, without 
endosperm; vascular strands in the testa often not confined to a thickened part; embryo longitudinal, cotyledons (usually) equal and thick radicle short and apical.

The neotropical genus Olmedia (as well as the palaeotropical genera Antiaropsis and Sparattosyce) had to be excluded from the group of genera ranked among the Olmedieae and the tribe had to be renamed (Berg 1977). An important character of the neotropical Castilleae is the occurrence of self-pruning branches connected with the architecture and growth of the trees. Adopting the distinctions made by Hallé and Oldeman (1970) the members of the Castilleae can be inserted in the "model of Cook" the "model of Roux" or the "model of Corner". The authors placed Antiaris in the "model of Roux". Young specimens of Antiaris show the features of the "model of Cook" because of shedding of branches, which phenomenon was (probably) indepently reported for Antiaris by Lynch (1877), Trimen (1898), and de Wit (1963). Nothing is known about growth habit and presence of self-pruning branches in Mesogyne.

In the neotropical Castilleae the more or less bitter, watery component of the latex turns pinkish brown or sometimes blackish after exposure to the air. The same change of colour is reported for Antiaris. Although the Castilleae have these features of the latex in common, latex with a bitter taste and/or turning pinkish or brownish appears to be rather widely distributed in the Moraceae.

The closely related genera Antiaris and Mesogyne differ from the neotropical members of the tribe in the arrangement of the bracts. In the neotropical genera the bracts form a distinct involucre of imbricate bracts, even in the infructescence. In the two Old World genera the bracts are partly scattered, especially in the fruiting pistillate inflorescence. In contrast to the neotropical genera, Antiaris and Mesogyne have a thickened part in the testa, containing the greater part of vascular bundels in the testa. Moreover, the buds forming permanent branches are placed above the insertion of the selfpruning branches in Antiaris, but beside the insertion of the selfpruning branches in the New World representatives. In spite of the differences the two groups of genera match very well.

\section{Key to the genera of the Castilleae}

1.a. Stipules semi-amplexicaul; staminate inflorescences with many involucral bracts; fruiting perianth densely hairy; cotyledons equal . . . . 6. Antiaris

b. Stipules fully amplexicaul; staminate inflorescences with 4 involucral bracts; fruiting perianth sparsely hairy; cotyledons unequal . . . . . 7. Mesogyne 
6. Antiaris Lesch., Ann. Mus. Hist. Nat. Paris 16: 478 (1810), nom. conserv.; Corner, Gard. Bull. Singapore 19 : 244 (1962). Type species : A. toxicaria Lesch.

Monoecious or dioecious trees. Leaves (at least on twigs) distichous, pinnately veined; stipules free, semi-amplexicaul. Inflorescences on short-shoots in the axils of the leaves or below the leaves, with 1-2 pistillate inflorescences (on the lower nodes of the short-shoot) and/or up to ca. 8 staminate ones. Staminate inflorescences discoid, pedunculate, many basally attached bracts, those on the margin of the receptacle in 1-3 rows, imbricate, forming an involucre; flowers many, with 2-7 free tepals; stamens 2-4, straight before anthesis, anthers latrorse to extrorse; pistillode absent. Pistillate inflorescences sessile or pedunculate, with an involucre of several basally attached imbricate bracts, flower 1 , occasionally 2; perianth 4-lobed, the lower part adnate to the receptacle; ovary adnate to the embedded part of the perianth, stigmas 2 . Infructescences with an orange to scarlet, fleshy receptacle, forming a whole with the fruit; endocarp crustaceous; testa thin, with a large suborbicular closely vascularized thickened part below the hilum; embryo longitudinally aligned, cotyledons (almost) equal, radicle short and apical.

The Asian and Australasian species, all described in the past century, were united with $A$. toxicaria Lesch. by Corner (1962). African and Madagascan representatives of the genus were described only in this century by Engler (1902), Perrier de la Bâthie (1927), and Léandri (1948).

Before Engler described three African species in Antiaris, African material of this genus had already been referred to Asian Antiaris. Hiern (1900) regarded the collections made by Welwitsch in Angola as possibly belonging to Ipo toxicaria Pers. $(=A$. toxicaria Lesch.). African representatives of the genus were named Antiaris toxicaria var. africana by Scott Elliot (in Chevalier 1909). How closely African Antiaris is related to Asian Antiaris appeared from Corner's study (1962) on this genus. According to Corner the species recognized may be united into one broadly construed species, $A$. toxicaria.

On the basis of non-essential differences. (variation in leaf characters and the size and shape of the infructescences, connected with geographical distribution and ecology) Corner recognized:

A. toxicaria Lesch. var. toxicaria (from Sri Lanka to Celebes)

A. toxicaria Lesch. var. macrophylla (R. Br.) Corner (from the Philippines to Tonga) 
A. toxicaria Lesch. var. welwitschii (Engl.) Corner (tropical Africa)

A. africana Engl. (Western and Central tropical Africa)

A. madagascariensis $\mathrm{H}$. Perrier (Madagascar)

A. humbertii Léandri (Madagascar)

Mature infructescences, when dried, are ellipsoid to pyriform and up to $1.5 \mathrm{~cm}$ long in Africa, subglobose and $2.3 \mathrm{~cm}$ in diameter in Madagascar, and ellipsoid to pyriform and usually longer than $1.5 \mathrm{~cm}$ in the rest of the area of Antiaris. Var. macrophylla and A. humbertii are distinct in leaf shape and in the number of secondary leaf veins, respectively.

Until recently three species of Antiaris were generally recognized in Africa : A. africana Engl., A. welwitschii Engl., and A. usambarensis Engl. Corner put $A$. usambarensis into the synonymy of $A$. toxicaria var. welwitschii.

The material from the African continent is rather uniform in the characters of the inflorescence, flower, and infructescence. The main differences are found in the indument of twigs and leaves and in the venation (and texture) of the leaves.

Juvenile specimens (saplings, young trees, suckers) of the three taxa distinguished in Africa are rather similar and have their own combination of leaf and indument characters.

Regarding the variation within Antiaris and its segregates, it is clear that, even without adopting a broad species concept, all species recognized hitherto have to be brought together under one species, A. toxicaria. In this concept the following subdivision of the species appears to be proper :

Antiaris toxicaria Lesch.

- ssp. toxicaria

- ssp. macrophylla (R. Br.) C.C. Berg stat. et comb. nov., based on Antiaris macrophylla R. Br. in Flinders, Voy. Terra Austr. 2: 602, t. 5 (1814).

- ssp. africana (Engl.) C.C. Berg

- var. africana

- - var. welwitschii (Engl.) Corner

- - var. usambarensis (Engl.) C.C. Berg

- ssp. madagascariensis (H. Perrier) C.C. Berg

- ssp. humbertii (Léandri) C.C. Berg

On the main this subdivision is in accordance with Corner's views on Antiaris. Delimitation of the infra-specific taxa is based on non-essential 
differences in the indument, in leaf characters, and dimensions of the fructescences, in connection with their distribution. However, the distinct morphological resemblances between members of var. welwitschii and ssp. toxicaria are less reflected by the present subdivision. Except for ssp. humbertii (of which only four collections are known) all subspecies show more or less parallel variation patterns.

Antiaris challa (Schweinf.) Engl., Afr. Pflanzenw. 3(1): 33 (1915); Mildbr. \& Burret, Bot. Jahrb. 46: 264 (1911); Blatter, Rec. Bot. Surv. India 8(4) : 446 (1923); Swartz, Fl. Trop. Arab.: 25 (1939); Corner, Gard. Bull. Singapore 19 : 248 (1962). - Syntypes : Schweinfurth 416, Yemen, Gebel Bura (LE), and Schweinfurth 982, Yemen, Regma, near Hodjela = Holeida? (not seen).

Ficus challa Schweinf., Bull. Herb. Boiss., ser. 1, 4(App. II) : 144 (1896).

Engler (1915) regarded Ficus challa as identical with Antiaris usambarensis. Schweinfurth 416 (seen in LE) belongs without doubt to Antiaris toxicaria. In its leaf characters it matches ssp. africana var. africana. As long as no fruiting material is available, the position of the taxon remains uncertain.

6.1. Antiaris toxicaria Lesch., Ann. Mus. Hist. Nat. Paris 16: 478, pl. (1810); Hiern, Cat. Welw. Afr. Pl. 4 : 1020(1900).

6.1.a. Antiaris toxicaria Leschenault ssp. africana (Engl.) C.C. Berg comb. et stat. nov. - Lectotype: Warnecke 336, Togo, near Lome $(B$; isotypes $E, G, K, L, P$ ).

A. africana Engl., Bot. Jahrb. 33: 119 (1902); Hutch. in Prain, Fl. Trop. Afr. 6(2) : 224 (1917); Fl. Trop. W. Afr., ed. 2., 1(2): 612 (1958); Corner, Gard. Bull. Singapore 19 : 247 (1962).

Trees up to $40(-60) \mathrm{m}$ tall, with or without buttresses; latex white or yellowish turning pinkish or brownish; leafy twigs $1.5-5 \mathrm{~mm}$ thick, at least when dry more or less wrinkled and the periderm usually peeling off in small flakes, with yellowish to brown, patent or appressed-puberulous to hirtellous to subtomentose to hirsute, or to strigulose indument. 
Leaves oblong to elliptic, or sometimes to lanceolate, usually broadest in or above the middle, more or less inequilateral, (2-)6-17(-22) cm long, (1.5) $3-12 \mathrm{~cm}$ broad, subcoriaceous to coriaceous, shortly acuminate to apiculate, obtuse or sometimes subacute, at the base (subacute to) obtuse to (sub)cordate; margin subentire to denticulate towards the apex; above scabrous to scabridulous or smooth, the costa, especially in the lower part, more or less densely puberulous or hirtellous (to subtomentose), beneath sparsely appressed-puberulous to almost glabrous, or patent-puberulous to hirtellous to hirsute or to strigulose and often more or less scabrous; veins slightly prominent to plane above, beneath more or less prominent, the veinlets hardly or distinctly prominent, (5-)7-14 pairs of secondary veins, tertiary veins often partly parallel; petioles 3-9 $\mathrm{mm}$ long, with sparse or dense indument; stipules 3-10(-15) $\mathrm{mm}$ long, puberulous to pubescent to hirtellous or to hirsute, caducous. Inflorescences in the axils of the leaves or on (already) leafless twigs, on shortshoots bearing bract-like stipules. Staminate inflorescences 6-12(-20) $\mathrm{mm}$ in diam., mostly more or less lobed, at anthesis the margins deflexed; peduncle (4-)6-14(-18) $\mathrm{mm}$ long, densely puberulous to shortly velutinous, sometimes bracteate; receptacle puberulous to shortly velutinous, bracts (sub)ovate to oblong to elliptic, imbricate, up to ca. $1 \mathrm{~mm}$ long and below several scattered bracts extending to the peduncle; flowers many; perianth 1-1.5(-1.7) $\mathrm{mm}$ high, with (2-)3-5(-7) free, more or less spathulate, flat, cucullate or subpeltate, puberulous tepals; stamens (2-) 3-4, filaments $0.2-0.4 \mathrm{~mm}$ long, anthers $0.8-1.8 \times 0.4-0.7 \mathrm{~mm}$, connective rather narrow, apiculate or not. Pistillate inflorescences $3-4 \mathrm{~mm}$ high, ca. $3 \mathrm{~mm}$ in diam., ellipsoid (to turbinate), sessile to pedunculate; peduncle up to 3 (or 6) $\mathrm{mm}$ long, densely puberulous to short-velutinous; receptacle bearing up to 12 , mostly ca. 8 imbricate, reniform to ovate, puberulous bracts in several rows; flower 1(-2); free part of the perianth ca. $2 \mathrm{~mm}$ high, 4-parted, puberulous; style up to $1 \mathrm{~mm}$ long, stigmas filiform to vittiform, (2-)5-7(-10) $\mathrm{mm}$ long, minutely puberulous. Infructescences ellipsoid, sometimes nearly ovoid or globose, $1-1.5 \mathrm{~cm}$ long, $0.8-1 \mathrm{~cm}$ in diam., short- or long-apiculate, receptacle fleshy, brownish short-velutinous (with swollen hairs), with scattered bracts; peduncle 3-12 $\mathrm{mm}$ long; endocarp body ca. $10 \mathrm{~mm}$ long, endocarp crustaceous; seed ca. $7-9 \mathrm{~mm}$ long, testa (at least in dried material) adhering to the endocarp, rather thin, vascularized, closely so in a suborbicular to oblong, not distinctly thickened part below the hilum; embryo often marked by the thickened part of the testa and vascular bundles departing from that part; cotyledons equal or nearly so. 


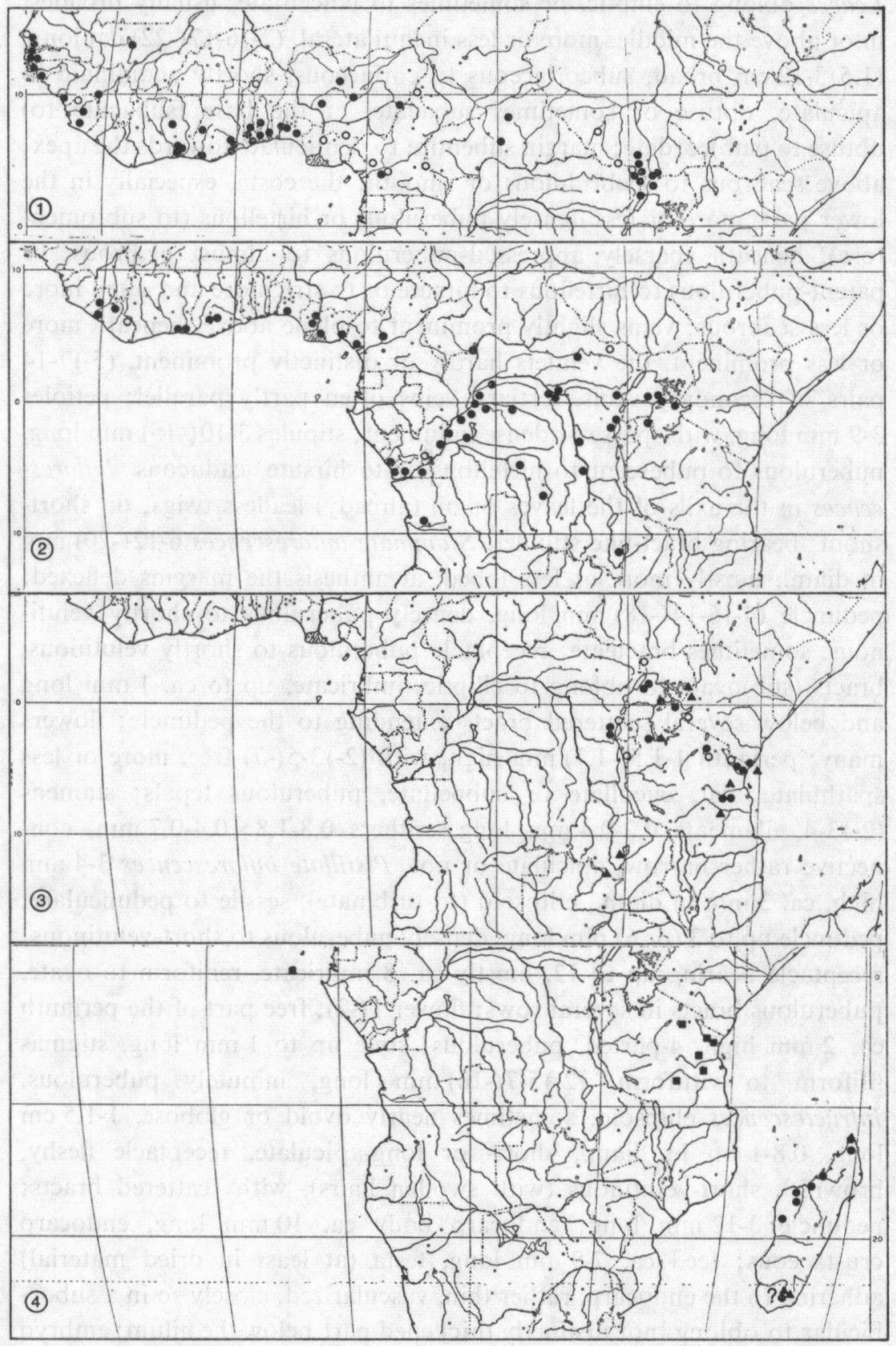

Fig. 8. - Distribution of taxa of the Castilleae : map 1, Antiaris toxicaria ssp. africana var. africana, adult specimens, $O$ juvenile specimens probably belonging to var. africana; map 2, A. toxicaria ssp. africana var. welwitschii, adult specimens, $O$ juvenile specimens probably belonging to var. welwitschii; map 3, A. toxicaria ssp. africana var. usambarensis, - adult specimens, $O$ juvenile specimens probably belonging to var. usambarensis, $A$ juvenile specimens of uncertain identity; map 4, and $7 A$. toxicaria ssp. madagascariensis. $\triangle$ A. toxicaria ssp. humbertii, 1 Mesogyne insignis. 
Juvenile specimens: Leafy twigs hirtellous, subtomentose, hirsute or (sub)hispid, the hairs of the same length and then relatively long or of different length; leaves often oblong to lanceolate, chartaceous to subcoriaceous (to coriaceous); above hirsute to (sub)hispid, usually scabridulous because of persisting hair bases, sometimes almost glabrous except for the hirsute main veins; beneath hirsute to subtomentose or (sub)hispid; margin usually distinctly dentate; apex long-acuminate to subacute; veins, especially the main ones, prominent beneath.

The juvenile features are more or less pronounced, probably depending on the age. Many specimens show transitions to the features of the adult specimens of the varieties distinguished. Suckers (which may arise from the roots) of adult trees also show juvenile features. These features are sometimes found in adult, at least flowering trees.

Distribution (fig. 8, maps 1-4): From Senegal to Tanzania, southward to Angola and Zambia, in forests in wet to dry situations, from sealevel to $800 \mathrm{~m}$ altitude; rare, common, or locally predominant.

Number of collections examined : ca. 290.

The infructescences are eaten by antilopes, monkeys, and birds. The wood is a timber and is used for making canoes, the (inner) bark is used for making cloth, hammocks, sacks etc. (cf. Voorhoeve 1965). The latex is used for adulterating rubber, it is poisonous (when brought into the blood-stream), and is regionally used to prepare arrow poison. (Kerharo \& Bouquet 1950; Walker 1953; Irvine 1961).

Three varieties can be distinguished within ssp. africana : var. africana, var. welwitschil, and var. usambarensis. In the regions where the (presumed) areas of var. welwitschii and var. africana overlap or approach each other, intermediate forms are (often) found. From the relatively scarce material we may cautiously conclude that the drier the habitat, the more pronounced the features of var. africana. On the other hand, the features of var. welwitschii are usually more distinct in regions with humid rain forests.

In East Africa material previously assigned to $A$. usambarensis shows a mixture of the characters of var. africana and var. welwitschii. Some of the East African specimens are exactly intermediate between the two taxa, like the type collection of $A$. usambarensis. Other specimens tend in their features towards either var. africana or var. welwitschii. The 
intermediate forms in East Africa are not quite like those found in West Africa.

The nature and the pattern in the variation of Antiaris in Africa raise the question if the differences, especially between var. africana and var. welwitschii, are genetically determined (by different chromosome numbers?, see p. 277) or mainly due to environmental factors. I am inclined to regard the environmental (climatological) conditions as important.

The varieties of ssp. africana are not clear-cut neither in their morphological features nor in their distributional areas. Uncertainty about the cause of the variation justifies distinction of the varieties, certainly with regard to var. africana and var. welwitschii. Distinguishing these varieties leads to recognition of var. usambarensis, partly because the type of A. usambarensis cannot be placed in one of the primary varieties.

The axillary short-shoots often produce both pistillate and staminate inflorescences, either (almost) simultaneously or successively. But they may produce only staminate ones or sometimes only pistillate ones. It is possible that part of the specimens only produce staminate inflorescences (depending on their age?). Trees may bear only staminate inflorescences beyond the main flowering time. For some regions [Angola, Liberia, see Hiern (1900); Voorhoeve (1965)] the trees (of var. welwitschii) are reported to be always dioecious. At anthesis separate flowers can be hardly distinguished in the staminate inflorescences.

The cotyledons are mostly strongly coherent or sometimes partly fused.

6.1.a'. Antiaris toxicaria Lesch. ssp. africana (Engl.) C.C. Berg var. africana. - Fig. 9.

A. toxicaria var. africana Scott Elliot ex A. Chev., Végét. Ut. Afr. Trop. Fr. 5: 259 (1909). - Syntypes: Chevalier 16107 and 16217, Ivory Coast, respectively Bouroukrou and Dabou (K, P).

A. kerstingii Engl., Pflanzenw. Afr. 3(1): 33, t. 20A (1915), very briefly described, but with a good plate. - Type : von Sokode s.n., Togo, Basari (B?, not seen).

Leafy twigs puberulous, hirtellous to subtomentose, or strigose, sometimes hirsute; periderm usually distinctly peeling off. Leaves subcoriaceous to coriaceous; above hirtellous to subhispid(ulous), (scabridulous to) scabrous by persisting hair bases or more frequently by short rigid hairs, the costa often strigose to hirtellous; beneath hirtellous, 


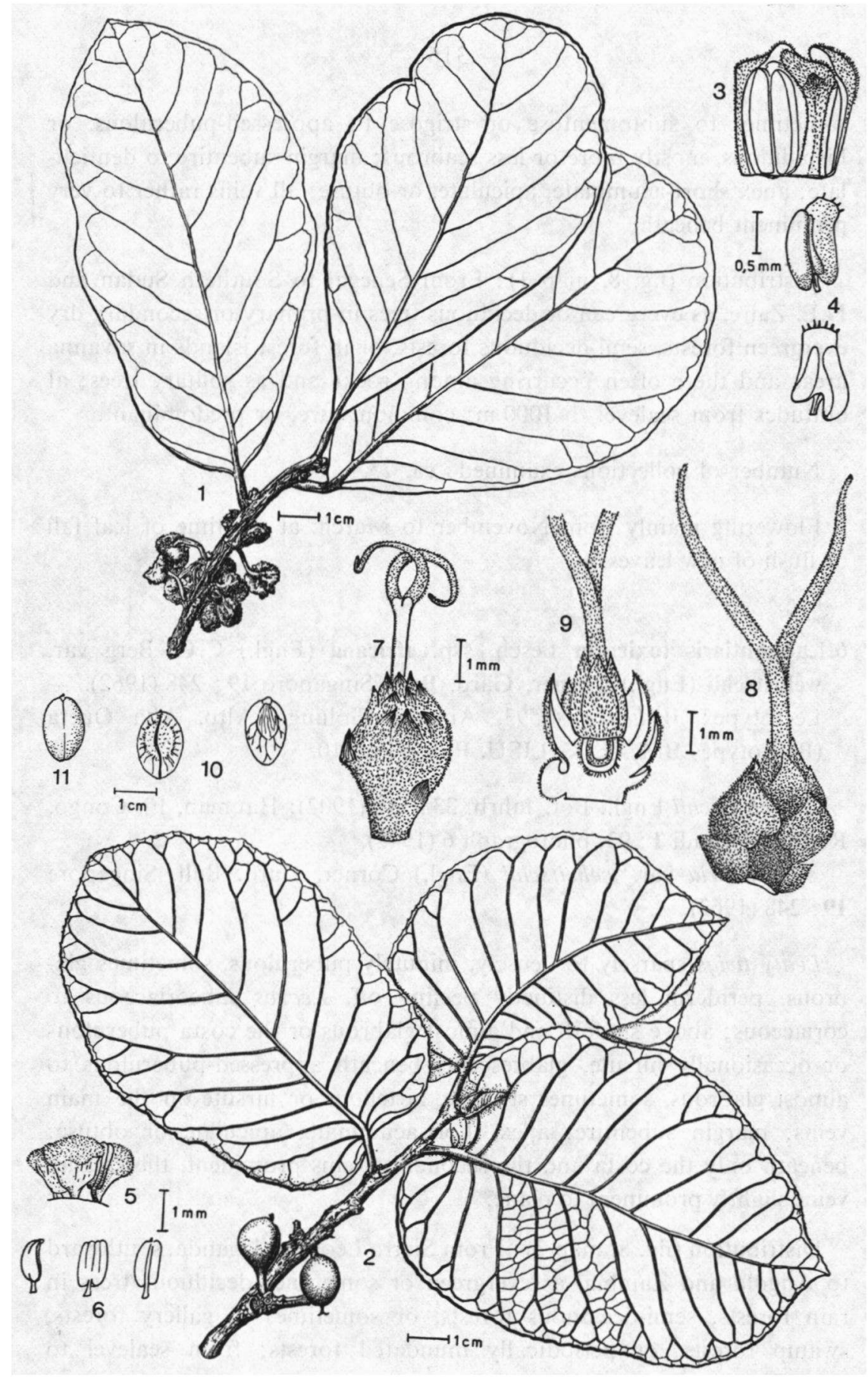

Fig. 9. - Antiaris toxicaria ssp. africana var. africana: 1, leafy twig with staminate inflorescences; 2, leafy twig with pistillate inflorescences; 3 , staminate flower; 4 , stamens; 5 , staminate flower; 6, stamens; $7 \& 8$, pistillate inflorescences; 9, pistillate flower; 10, seeds; 11 , embryo $(1,10,11$ : Kersting A $571 ; 2:$ Esperito Santo 1741 ; 3, 4, 7 : Dalziel 177; 5, 6: de Wilde 1373; 8, 9: d'Orey 296). 
sometimes to subtomentose or strigose to appressed-puberulous, or hispidulous, mostly more or less scabrous; margin subentire to denticulate; apex short-acuminate, apiculate, or obtuse; all veins rather to very prominent beneath.

Distribution (fig. 8, map 1): From Senegal to Southern Sudan and N.E. Zaire, as evergreen or deciduous trees in primary or secondary dry evergreen forests, semi-deciduous forests, or in forest islands in savanna areas and there often occurring among rocks and as solitary trees; at altitudes from sealevel to $1000 \mathrm{~m}$; common, rare, or predominant.

Number of collections examined : ca. 75.

Flowering mainly from November to March, at the time of leaf fall or flush of new leaves.

6.1.a". Antiaris toxicaria Lesch. ssp. africana (Engl.) C.C. Berg var. welwitschii (Engl.) Corner, Gard. Bull. Singapore 19: 248 (1962). Lectotype: Welwitsch 2593, Angola; Golungo Alto, Alta Queta (B; isotypes BM, G, K, LISU, P). - Fig. 10.

A. welwitschii Engl., Bot. Jahrb. 33 : 118 (1902); Hauman, Fl. Congo, Ruanda-Urundi $1: 93$, photograph 6 (1948).

A. toxicaria var. welwitschii (Engl.) Corner, Gard. Bull. Singapore 19 : 248 (1962).

Leafy twigs sparsely to densely, minutely puberulous, sometimes glabrous, periderm less distinctly peeling off. Leaves subcoriaceous to coriaceous; above smooth and almost glabrous or the costa puberulous or occasionally hirsute, glabrescent; beneath appressed-puberulous to almost glabrous, sometimes strigose, hirtellous or hirsute on the main veins; margin subentire; apex short-acuminate, apiculate or obtuse; beneath only the costa and the secondary veins prominent, the smaller veins slightly prominent to plane.

Distribution (fig. 8, map 2) : From Sierra Leone to Uganda, southward to Angola and Zambia, as evergreen or sometimes deciduous trees in rain forests, semi-deciduous forests, or sometimes in gallery forests, swamp forests, or periodically inundated forests; from sealevel to ca. $1300 \mathrm{~m}$; common or rare.

Number of collections examined : ca. 105. 


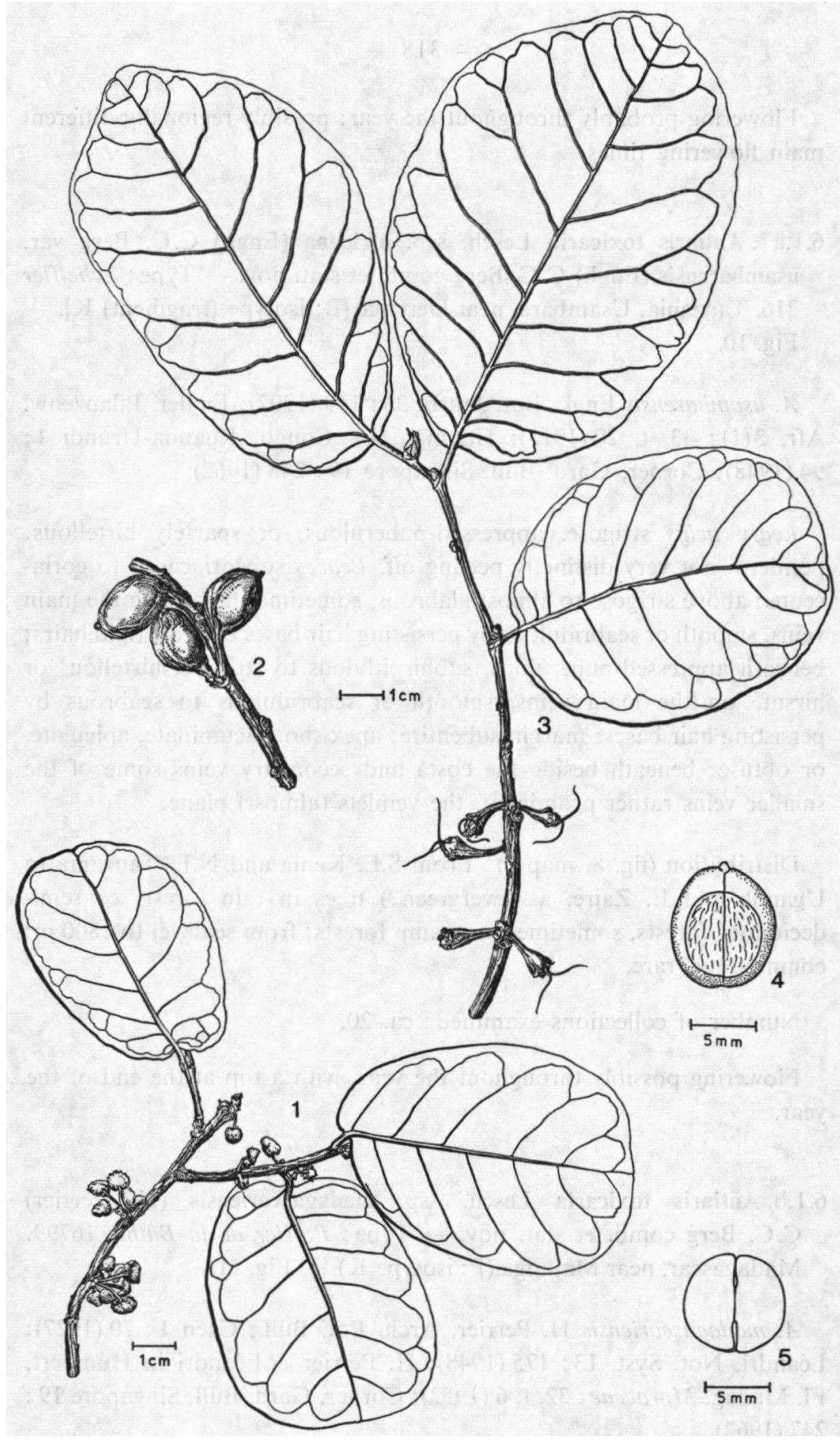

Fig. 10. - Antiaris toxicaria ssp. africana var. welwoitschil : 1, leafy twig with staminate inflorescences; 2, leafy twig with pistillate inflorescences; 3, twig with infructescences (1: Flamigni 10490; 2 : Deured 762; 3 : Toka 26). - Antiaris africana ssp. africana var. usambarensis : 4, seed; 5 , cross section of embryo (Gille 282). 
Flowering probably throughout the year; possibly regionally different main flowering times.

6.1.a ${ }^{\mathrm{m}}$. Antiaris toxicaria Lesch. ssp. africana (Engl.) C.C. Berg var. usambarensis (Engl.) C.C. Berg comb. et stat. nov. - Type : Scheffler 216, Tanzania, Usambara, near Derema [B; isotype (fragment) $\mathrm{K}$ ]. Fig. 10.

A. usambarensis Engl., Bot. Jahrb. 33 : 119 (1902); Engler, Pflanzenw. Afr. 3(1): 33, t. 20 (1915); Hauman, Fl. Congo, Ruanda-Urundi 1 : 94 (1948); Corner, Gard. Bull. Singapore 19 : 248 (1962).

Leafy twigs strigose, appressed-puberulous, or sparsely hirtellous; periderm not very distinctly peeling off. Leaves subcoriaceous to coriaceous; above strigose to almost glabrous, sometimes hirsute on the main veins, smooth or scabridulous by persisting hair bases or short rigid hairs; beneath appressed-puberulous, subhispidulous to strigose, hirtellous or hirsute on the main veins, smooth or scabridulous to scabrous by persisting hair bases; margin subentire; apex short-acuminate, apiculate, or obtuse; beneath beside the costa and secondary veins some of the smaller veins rather prominent, the veinlets (almost) plane.

Distribution (fig. 8, map 3) : From S.E. Kenia and N.E. Tanzania to Uganda and E. Zaire, as (evergreen?) trees in rain forests or semideciduous forests, sometimes in swamp forests; from sealevel to $1800 \mathrm{~m}$; common or rare.

Number of collections examined : ca. 20.

Flowering possibly throughout the year, with a top at the end of the year.

6.1.b. Antiaris toxicaria Lesch. ssp. madagascariensis (H. Perrier) C.C. Berg comb. et stat. nov. - Type: Perrier de la Bâthie 16799, Madagascar, near Majunga (P; isotype $\mathrm{K})$. - Fig. 11.

A. madagascariensis H. Perrier, Arch. Bot. Bull., Caen 1 : 70 (1927); Léandri, Not. Syst. 13 : 175 (1948); H. Perrier \& Léandri in Humbert, Fl. Madag. Moraceae : 32, t. 6 (1952); Corner, Gard. Bull. Singapore 19 : 247 (1962). 


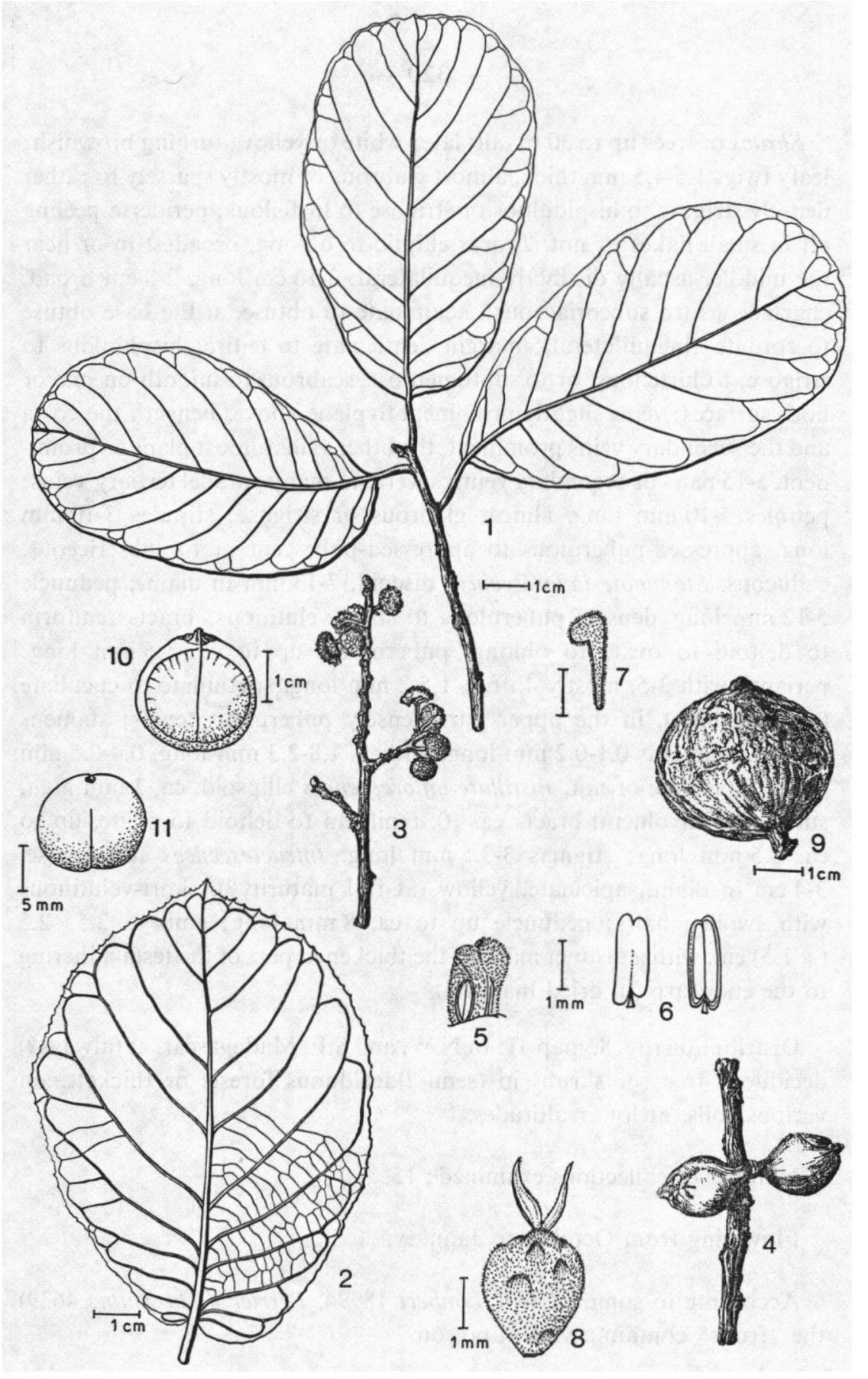

Fig. 11. - Antiaris toxicaria ssp. madagascariensis : 1, leafy twig; 2, leaf; 3, twig with staminate inflorescences; 4 , twig with pistillate inflorescences; 5 , staminate flower; 6 , id., stamens; 7, id., tepal; 8, pistillate flower; 9, infructescence; 10, embryo; 11, embryo (1, 9, 10: Serv. For. Madag. 13412; 2, 4: Capuron 18846; 3, 5-8: Capuron 8544; 11 : Perrier de la Bathie 16799). 
Shrubs or trees up to $30 \mathrm{~m}$ tall; latex white or yellow, turning brownish; leafy twigs $1.5-4.5 \mathrm{~mm}$ thick, almost glabrous or mostly sparsely to rather densely strigose to hispidulous or strigose to hirtellous; periderm peeling off in small flakes or not. Leaves elliptic to oblong, broadest in or near the middle, usually distinctly inequilateral, $3-16 \mathrm{~cm}$ long, $2-8 \mathrm{~cm}$ broad, chartaceous (to subcoriaceous), acuminate to obtuse, at the base obtuse to cordate (inequilateral); margin denticulate to entire; hispidulous to strigose, to hirtellous, or to subtomentose, scabrous to smooth on one or both surfaces; veins slightly prominent to plane above, beneath the costa and the secondary veins prominent, the other veins almost plane to prominent, 5-15 pairs of secondary veins, several to many parallel tertiary veins; petioles $5-10 \mathrm{~mm}$ long, almost glabrous or strigose; stipules $3-10 \mathrm{~mm}$ long, appressed-puberulous to appressed-pubescent or to subsericeous, caducous. Staminate inflorescences discoid, $7-13 \mathrm{~mm}$ in diam.; peduncle 5-12 mm long, densely puberulous to short-velutinous; bracts reniform to deltoid to ovate to oblong, puberulous, up to ca. $1.5 \mathrm{~mm}$ long; perianth with 3-5, mostly 4 , free, $1.5-2 \mathrm{~mm}$ long, spathulate to cucullate (to subpeltate), in the upper part densely puberulous tepals; stamens (2-) 3-5, filaments 0.1-0.2 mm long, anthers 1.8-2.3 mm long, 0.4-0.5 mm broad, apiculate or not. Pistillate inflorescences ellipsoid, ca. $3 \mathrm{~mm}$ high, subsessile; involucral bracts ca. 10 , reniform to deltoid to ovate, up to ca. $0.5 \mathrm{~mm}$ long; stigmas $3-3.5 \mathrm{~mm}$ long. Infructescences subglobose, $3-4 \mathrm{~cm}$ in diam., apiculate, yellow (at full maturity?), short-velutinous with swollen hairs; peduncle up to ca. $8 \mathrm{~mm}$ long; embryo $2.5 \times 2.5$ $(\times 1.5) \mathrm{cm}$, with a distinct mark of the thickened part of the testa adhering to the endocarp (in dried material;.

Distribution (fig. 8, map 4) : In N.W. and S.E. Madagascar, as (always?) deciduous trees or shrubs in (semi-?)deciduous forests or thickets, on various soils, at lower altitudes.

Number of collections examined : 15 .

Flowering from October to January.

According to some labels (Humbert 18994, Perrier de la Bâthie 4629) the "fruits" contain a violent poison.

The two Madagascan subspecies are distinct by their large, (sub) globose infructescences. Ssp. humbertii (only known by four collections of fruiting specimens growing in xerophytic bush) differs from ssp. 
madagascariensis in the smaller number of secondary leaf veins and the very rough leaf surface.

Ssp. madagascariensis shows the same variation in indument and venation as ssp. africana, although less pronounced.

Although trees of ssp. madagascariensis can grow to a height of $30 \mathrm{~m}$, several collections have been made from flowering or fruiting small trees or even shrubs. Corner (1962) mentioned the occurrence of shrubby plants in ssp. macrophylla.

The hairs on the leaves are patent to appressed, straight or curved, very short and rigid, or longer and weaker, straight, curved, or almost crinkled. The different types of hairs gradually pass into each other. The roughness of the leaf surface is caused by short rigid hairs and/or the persisting swollen bases of longer hairs.

In general appearance two not highly distinct groups of specimens can be distinguished within the collected material of ssp. madagascariensis.

\section{Group A}

Leaves tending to be elliptic and broadest above the middle, with a shortly acuminate to obtuse apex, with relatively long hairs and therefore the leaf surface not or hardly scabrous, and further with prominent tertiary (and quaternary) veins beneath; the periderm of the twigs (also invested with relatively long hairs) peels off in small fiakes.

This group comprises, among other collections: Capuron 18846, Homolle 358, Humbert 18994, and Serv. For. Madagascar 13142.

\section{Group B}

Leaves tending to be oblong and long-acuminate (to subacute) at the apex, usually with short hairs, with the leaf surface smooth or scabrous, with tertiary and quaternary veins slightly prominent to (almost) plane beneath; the periderm of the twigs usually not peeling off in small flakes.

This group comprises, among other collections : Capuron 24578 (leaves scabrous on both surfaces), Léandri et al. 2117, 2735, Perrier de la Bâthie 4629, 16799.

6.1.c. Antiaris toxicaria Lesch. ssp. humbertii (Léandri) C.C. Berg comb. et stat. nov. - Lectotype: Humbert 12320, Madagascar, between Tsivory and Anadabolava (P). - Fig. 12. 


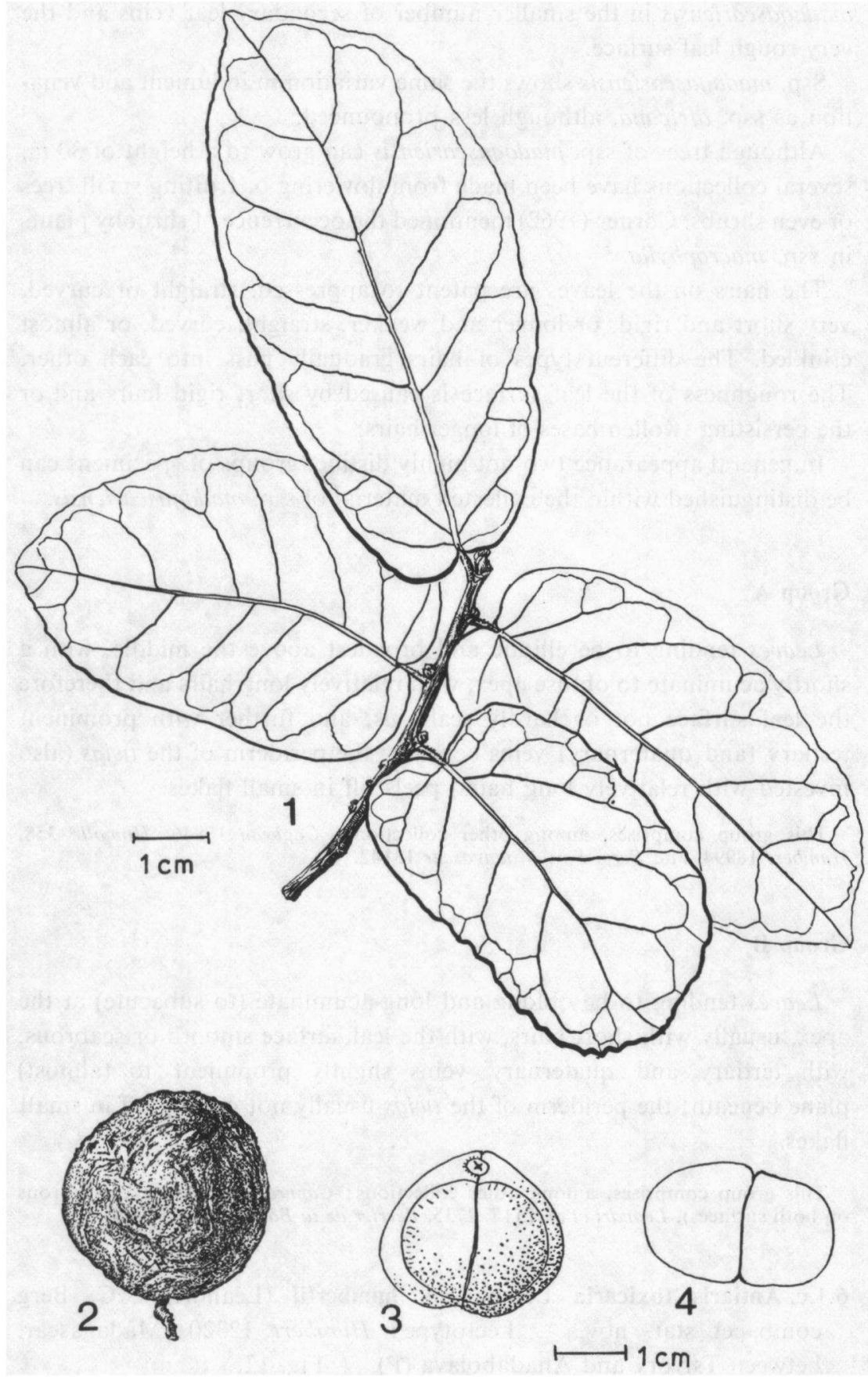

Fig. 12. - Antiaris toxicaria ssp. humbertii: 1, leafy twig; 2, infructescence; 3, embryo; 4, cross section of embryo (Capuron 22430). 
A. humbertii Léandri, Not. Syst. 13 : 175 (1948); H. Perrier \& Léandri in Humbert, Fl. Madag. Moraceae : 32, t. 6 (1952); Corner, Gard. Bull. Singapore 19 : 247 (1962).

Small trees or shrubs with white to yellow latex (turning brownish?). Leafy twigs $1-3 \mathrm{~mm}$ thick, strigose to hispidulous. Leaves elliptic to oblong, broadest in or near the middle, usually distinctly inequilateral, $2-8.5 \mathrm{~cm}$ long, $1-5 \mathrm{~cm}$ broad, chartaceous (to subcoriaceous), shortly acuminate to obtuse or sometimes to subacute, at the base obtuse to cordate; margin denticulate to faintly repand or subentire; both surfaces very rough by short rigid patent hairs, beneath on the main veins some longer appressed hairs; veins slightly prominent to plane above, beneath prominent, 4-8 pairs of secondary veins, parallel tertiary veins few or lacking; petioles 2-5 mm long, hispidulous to strigose; stipules 2-4 mm long, strigose. Infructescences subglobose, ca. $2.5-3 \mathrm{~cm}$ in diam., velutinous with short swollen hairs, shortly pedunculate to subsessile; endocarp body $2.5-3 \mathrm{~cm}$ in diam., endocarp subcrustaceous; testa (at least in dried material) adhering to the endocarp, thin, below the hilum a thickened, closely vascularized, suborbicular, ca. $1.5 \mathrm{~cm}$ broad part leaving a distinct mark on the embryo; embryo (in dried material) ca. $1.5 \times 2.5 \mathrm{~cm}$, cotyledons equal.

Distribution (fig. 8, map 4): Madagascar, only known from the Mandrare Basin, in xerophytic bush, at altitudes up to $900 \mathrm{~m}$.

The collections examined : 4 .

Fruiting specimens collected from December to February.

The leaf characters of this subspecies might prove to be due to very dry conditions.

7. Mesogyne Engl., Bot. Jahrb. 20 : 147 (1894); Hutch. in Prain, Fl. Trop. Afr. 6(2) : 222 (1917); Corner, Gard. Bull. Singapore 19: 224, 250 (1962). - Type species: $M$. insignis Engl., see Hutch., Gen. Flow. Pl. 2: 171 (1967).

Monoecious shrubs or small trees. Leaves (at least on the twigs) distichous, pinnately veined; stipules free, fully amplexicaul. Inflorescences on leafless short-shoots in the leaf axils, usually 1-2 pistillate ones (on the lower nodes) and up to 6 (or more) staminate ones. Staminate 
inflorescences discoid to hemispherical, with 3-4 basally attached imbricate bracts forming an involucre, pedunculate, with several to many flowers; perianth 2-4-parted; stamens 4-2, straight before anthesis; anthers extrorse to latrorse; pistillode lacking or rare. Pistillate inflorescences uniflorous, sessile, involucre with several basally attached imbricate bracts; flowers basally adnate to the receptacle; ovary basally adnate to the 3-4-lobed perianth, stigmas 2 . Infructescences with a red, fleshy receptacle forming a whole with the fruit; endocarp crustaceous; testa with a large, oblong, thickened, closely vascularized part below the hilum; embryo longitudinally aligned; cotyledons very unequal; radicle apical and short.

In 1894 Engler established the genus Mesogyne and described two species : $M$. Insignis on material from Tanzania and $M$. henriquesii on material from São Tomé. He placed Mesogyne in the Dorstenieae. The results of Tippo's study (1938) on the anatomy of the wood of Moraceae and allied groups could already raise doubt about the accepted position of the genus. Corner (1962) referred the genus to the Olmedieae and placed it close to Antiaris. He even suggested to unite the two genera.

The close relationships between these genera are clear, but uniting them now would be premature. Unequal cotyledons are unusual in the Castilleae, as well as the very small number of involucral bracts of the manyflowered staminate inflorescence. Knowledge about the habit, growth, and presence of self-pruning branches may assist in establishing the position of Mesogyne.

The nature of the differences within the genus do not justify the maintainance of two species.

7.1. Mesogyne insignis Engl., Bot. Jahrb. 20 : 148, t. 5 (1894), Engl., Monogr. Afr. Pfl. 1 (Moraceae): 30, t. 11 (1898). - Lectotype: Holst 2290, Tanzania, Usambara, near Nguelo (B). - Fig. 13.

M. henriquesii Engl., Bot. Jahrb. 20 : 148 (1894); Exell, Cat. Vasc. Pl. S. Tomé : 309 (1944). - Type : Quintas 164, Sð̃o Tomé, near Angolares (COI, not seen; isotype B).

Shrubs or trees up to $15(-40$ ?) $\mathrm{m}$ tall; leafy twigs $1-3(-4) \mathrm{mm}$ thick, sparsely appressed-puberulous. Leaves (elliptic to) oblong (to lanceolate), broadest in or above the middle, usually more or less inequilateral, $5-26 \mathrm{~cm}$ long, $1.5-9 \mathrm{~cm}$ broad, chartaceous to subcoriaceous (to coria- 


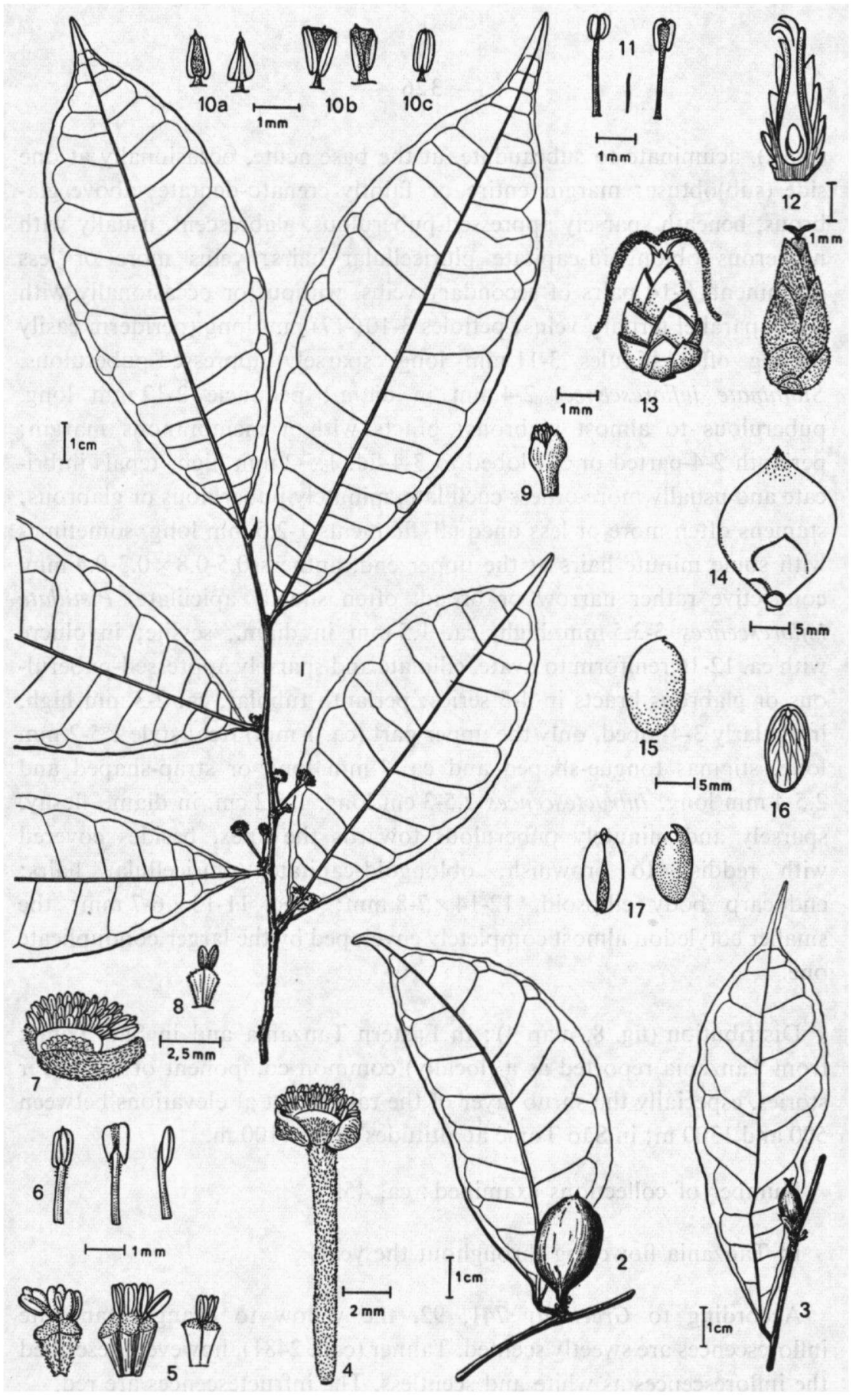

Fig. 13. - Mesogyne insignis: 1, leafy twig with staminate inflorescences; 2 , leaf and pistillate inflorescence; 3 , leaf and infructescence; 4 , staminate inflorescence; 5 , staminate flowers; 6 , stamens; 7, staminate inflorescence; 8 \& 9, staminate flowers; 10a, b \& c, stamens; 11, stamens and pistillode; 12 \& 13, pistillate inflorescences; 14 , young infructescence; 15 , endocarp body; 16 , seed; 17 , embryo with a small cotyle. don (1: Drummond \& Hemsley 1841; 2, 12 : Drummond \& Hemsley 1692; 3 : Faulkner 1346 ; 4-6: Warnecke 461; 7, 8: Drummond \& Hemsley 1694; 9-11: Quintas 1062; 13: Chevalier 8.n.; 14-17 : Semset 1447). 
ceous), acuminate to subcaudate, at the base acute, occasionally at one side (sub)obtuse; margin entire or faintly crenato-dentate; above glabrous, beneath sparsely appressed-puberulous, glabrescent, usually with numerous oblongoid-capitate pluricellular hairs; veins more or less prominent, 9-14 pairs of secondary veins, without or occasionally with a few parallel tertiary veins; petioles 3-10(-17) $\mathrm{mm}$ long (periderm easily peeling off); stipules 3-11 mm long, sparsely appressed-puberulous. Staminate inflorescences $2-4 \mathrm{~mm}$ in diam.; peduncle $2-12 \mathrm{~mm}$ long, puberulous to almost glabrous; bracts with a membranous margin; perianth 2-4-parted or 3-4-lobed to 3-4-fid, 1.5-2 mm high, tepals imbricate and usually more or less cucullate, minutely puberulous or glabrous; stamens often more or less unequal, filaments $1-2.5 \mathrm{~mm}$ long, sometimes with some minute hairs at the upper end, anthers $0.5-0.8 \times 0.3-0.4 \mathrm{~mm}$, connective rather narrow or broad, often shortly apiculate. Pistillate inflorescences $3-3.5 \mathrm{~mm}$ high, ca. $1.5 \mathrm{~mm}$ in diam., sessile; involucre with ca. 12-16 reniform to ovate, ciliolate and sparsely appressed-puberulous or glabrous bracts in 4-5 series; perianth tubular, ca. 2-3 mm high, irregularly 3-4-lobed, only the upper part (ca. $1 \mathrm{~mm}$ ) free; style $1.5-2 \mathrm{~mm}$ long, stigmas tongue-shaped and ca. $1 \mathrm{~mm}$ long or strap-shaped and 2.5-4 mm long. Infructescences $2.5-3 \mathrm{~cm}$ long, $1.5-2 \mathrm{~cm}$. in diam., fleshy, sparsely and minutely puberulous towards the apex, besides covered with reddish to brownish, oblongoid-capitate, pluricellular hairs; endocarp body ellipsoid, $12-14 \times 7-8 \mathrm{~mm}$; seed $11-13 \times 6-7 \mathrm{~mm}$; the smaller cotyledon almost completely enveloped by the larger conduplicate one.

Distribution (fig. 8, map 4): In Eastern Tanzania and in São Tomé; from Tanzania reported as a (locally) common component of the lower stories, especially the shrub layer of the rain forest at elevations between 500 and $1300 \mathrm{~m}$; in São Tomé at altitudes up to $1100 \mathrm{~m}$.

Number of collections examined : ca. 45.

In Tanzania flowering throughout the year.

According to Greenway 741, 92, the yellow to orange staminate inflorescences are sweetly scented. Tanner (coll. 2481), however, described the inflorescences as white and scentless. The infructescences are red.

The material from Sæo Tomé differs from that from Eastern Tanzania in the longer (2.5-4 mm long) and strap-shaped stigmas, in the less deeply 
divided perianth of the staminate flower, in the somewhat shorter (2-4 $\mathrm{mm}$ long) peduncle of the staminate inflorescence, and often in the somewhat thicker (coriaceous) leaves. Because of the scarcity of material nothing can be concluded about the constancy of these differences. Therefore it is not desirable to distinguish infraspecific taxa at this moment.

In the staminate inflorescences of East African specimens the inner flowers are often 4-merous, whereas the peripheral ones are often 2merous and less well-developed, their stamens usually being smaller and often irregularly shaped.

\section{Moreae}

Trees or shrubs (sometimes climbing and/or armed) rarely herbs (Fatoua). Leaves in two rows or in spirals, stipules mostly free; uncinate hairs general; occasionally septate wood fibres (Prainea) or cardiac glycosides (Streblus, Antiaropsis) present. Inflorescences usually unisexual, mostly spicate, racemose or capitate [and sometimes (sub)involucrate because of the presence of several (large) basal bracts], sometimes cymose or discoid and involucrate; bracts often peltate; stamens straight or inflexed and then mostly springing back elastically; pistillodes general; perianth of the pistillate flower with free or connate tepals, sometimes lacking. Fruit free or adnate to the perianth; seeds large or small with or without endosperm, testa mostly with a thickened part having vascular strands, embryo very diverse.

In this circumscription of the tribe (cf. Berg 1973) the Artocarpeae, as defined by Corner (1962), are included. Reasons for combining the two tribes were the rather faint differentiating characters between the groups and the lack of sufficient homogeneity of each of them. Corner (1962 : 214) already considered fusing of the Moreae and the Artocarpeae.

The main problem in the Moreae is generic delimitation, owing to insufficiently understood and far from transparent patterns of variation and differentiation, gaps in our knowledge of several complexes of characters (morphological, anatomical, chemical), and uncertainty about the significance of the characters for delimitation. Especially for this tribe the differentiation of inflorescences, flowers, infructescences, and fruits have to be considered in connection with pollination and dispersal, data on which are very scarce.

The Moreae show some remarkable features: the incidental presence 
of characters characteristic for other tribes, for example septate wood fibres (Prainea), cardiac glycosides (Antiaropsis, Streblus asper), and striking differences in probably related taxa, e.g. in the indument (presence or absence of uncinate hairs), stamens (inflexed or straight stamens), and inflorescences (capitate or elongate, involucrate or not).

A world-wide comparative study, involving besides a wide range of morphological characters and anatomical and chemical properties, is necessary for the delimitation of the Moreae (at least against the Dorstenieae) and its genera, as well as of their subdivisions.

The generic descriptions in this treatment are only based on the characters of African species.

Several of the African Moreae were merged in Corner's broad genera Streblus, Maclura, and Trophis, or can be easily sunk in these genera. At the moment it appears wiser not to follow Corner, as expressed in the following review of the African members of the tribe. Therefore, I had to decide to leave the position of the African Moreae as far as possible unchanged, and consequently provisionally, also their names.

\section{Sloetiopsis - Bleekrodea - Fatoua}

Fatoua madagascariensis (and possibly also $F$. pilosa) is peculiar because of the lack of latex. Although the species is reminiscent of the Urticaceae in some features, the characters of the pistillate flower are Moraceous. They show relationships to Bleekrodea and Sloetiopsis.

These three genera (placed in the tribe Dorstenieae by Bureau (1873) have in common the well-developed white pulpy dehiscent exocarp, pushing upward or (in Fatoua probably) ejecting the endocarp body. Bleekrodea and Fatoua have bisexual inflorescences, although in $B$. madagascariensis and in $F$. madagascariensis unisexual inflorescences may occur. Sloetiopsis has unisexual, or occasionally bisexual inflorescences and is mostly dioecious, but sometimes monoecious. This group of genera (to which the Asian genus Sloetia can be added) may be regarded as basically monoecious, and their inflorescences as basically bisexual. The genus Fatoua has cymose inflorescences in the Asian species F. pilosa and spicate-racemose inflorescences in $F$. madagascariensis. This shows that the difference in structure of the inflorescences of Bleekrodea (cymose inflorescences) and Sloetiopsis (spicate staminate or bisexual inflorescences) is not essential.

A more important difference between Bleekrodea and Sloetiopsis as well as Fatoua can be found in the perianth of the pistillate flower. In Bleekrodea it is tubular and 4-dentate and in fruit the enlarged pinkish 


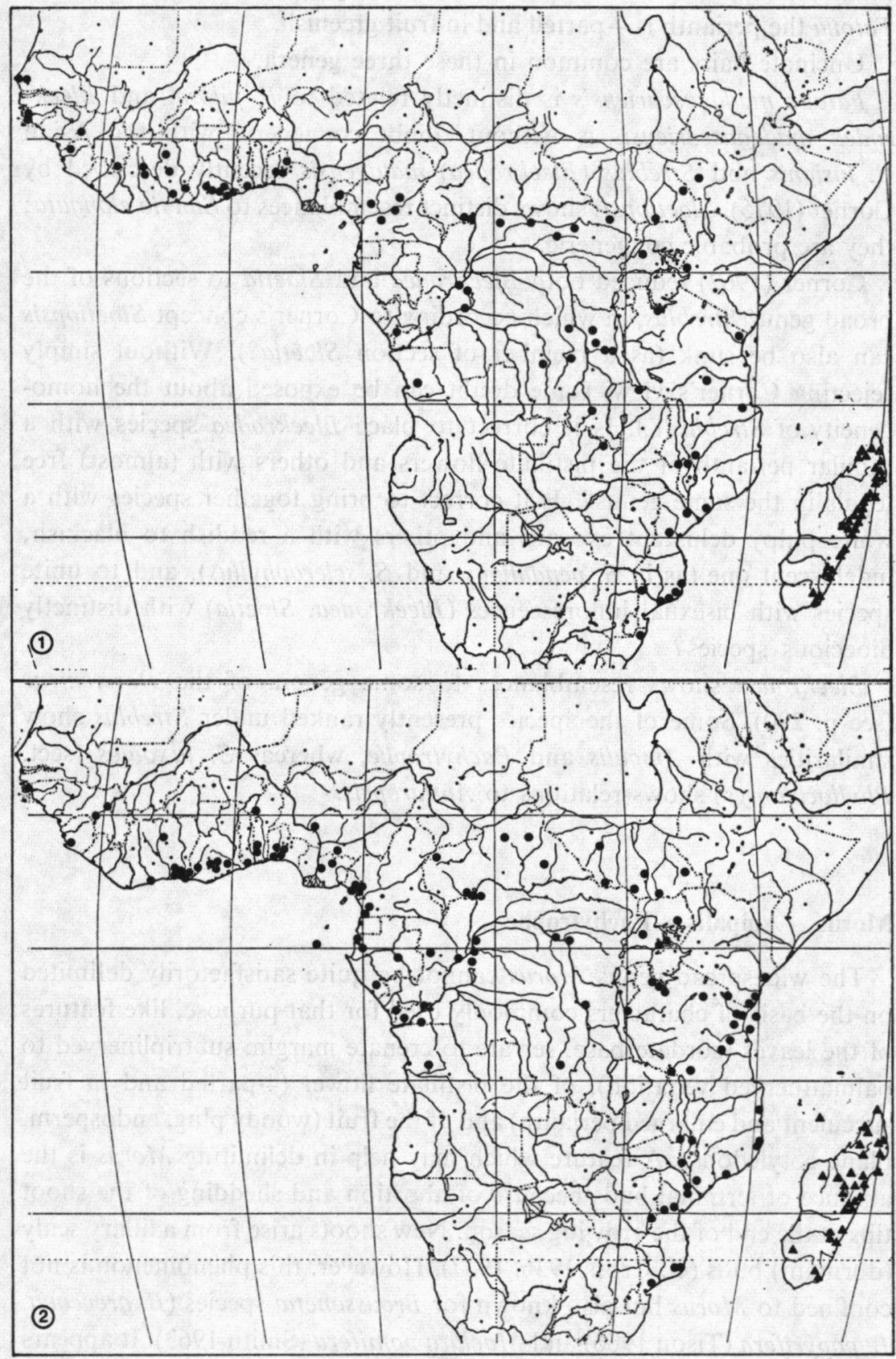

Fig. 14. - Distribution of some species of the Moreae : map 1, Morus mesozygia, $\Delta$ Pachytrophe dimepate; map 2, $\Delta$ Ampalis mauritiana, Chlorophora excelsa. 
perianth must be torn to release the endocarp body. In Sloetiopsis and Fatoua the perianth is 4-parted and in fruit greenish.

Uncinate hairs are common in these three genera.

Fatoua madagascariensis is distinctly related to F. pilosa, and Bleekrodea madagascariensis is without doubt congeneric with the Asian $B$. insignis and Streblus (Bleekrodea) malayensis recently described by Corner (1975). Sloetiopsis shows distinct resemblances to Sloetia elongata; they are probable congeneric.

Corner (1962) reduced both Bleekrodea and Sloetia to sections of the broad genus Streblus, in which according to Corner's concept Sloetiopsis can also be sunk (as a member of section Sloetia?). Without simply rejecting Corner's view, some doubt can be exposed about the homogeneity of Streblus s.l. Is it correct to place Bleekrodea species with a tubular perianth of the pistillate flowers and others with (almost) free tepals in the same genus? Is it correct to bring together species with a white pulpy dehiscent exocarp and others with a reddish to blackish, indehiscent one (as in S. pendulinus and S. sclerophyllus), and to unite species with bisexual inflorescences (Bleekrodea, Sloetia) with distinctly dioecious species?

Bleekrodea shows resemblances to some genera of the Dorstenieae (see p. 290). Some of the species presently ranked under Streblus show similarities with Ampalis and Pachytrophe, whereas $S$. taxoides (sect. Phyllochlamys) shows relations to Antiaropsis.

\section{Morus - Ampalis - Pachytrophe}

The widespread genus Morus cannot be quite satisfactorily delimited on the basis of characters commonly used for that purpose, like features of the leaves (cordate base, serrate to crenate margin, subtriplinerved to palmatinerved venation), of the pistillate flower (4-parted and in fruit succulent and enlarged perianth) and of the fruit (woody plug, endosperm, plane cotyledons). A feature which may help in delimiting Morus is the absence of terminal buds because of abortion and shedding of the shoot tips at the end of the growing season. New shoots arise from axillary scaly (dormant) buds (cf. Cross 1936, 1937). However, this phenomenon is not confined to Morus but also known for Broussonetia species (B. greveana, $B$. papyrifera (Tison 1906) and Maclura pomifera (Smith 1963). It appears to be correlated with occurrence in temperate regions (cf. Millington \& Chaney, in Kozlowski 1973). 
Ampalis and Pachytrophe are closely related and probably congeneric. If compared with Morus, Pachytrophe especially in its pistillate flowers and fruit is very similar, most distinctly so to Morus mesozygia. The two genera differ from Morus in the leaves, in the lack of well-developed scaly axillary buds, and in the absence of shedding of shoot tips. The two genera resemble several species of the genus Streblus sensu Corner, like $S$. ascendens, $S$. pendulinus, $S$. solomonensis, $S$. sclerophyllus (cf. Corner 1970). These Streblus species might prove to be more closely related to Ampalis and Pachytrophe (and through them linked to Morus) than to the Bleekrodea - Sloetia group. The leaves of S. ascendens are reminiscent of those of Morus species.

\section{Cardiogyne - Chlorophora (excelsa \& regia) - Broussonetia (greveana)}

a. Corner (1962) reduced Cardiogyne to a section of Maclura, which also comprises the former genera Cudrania (Asia) and Chlorophora (Africa and America). After excluding Chlorophora excelsa, $C$. regia, and C. $(=$ Broussonetia $)$ greveana, and including the Asian genus Plecospermum, there remains a group of climbers or trees whose short-shoots often end in a spine. Alle species of this group have globose pistillate inflorescences mostly developing into yellow to orange infructescences, the outer and protective layer of which is formed by the thickened upper parts of the perianths (and sometimes also of the bracts). The perianth and/or bracts mostly contain immersed yellow glands (accumulations of the copious yellow dye present in the plants) except for those of Plecospermum. The stipules are very small and scale-like, except in Chlorophora tinctoria. The petioles are thin and leave small scars, the leaves are thin and brittle when dried, one of the style branches is mostly more or less strongly reduced. Most species have short thin brown hairs on the vegetative parts. The staminate inflorescences are capitate, spicate, or racemose. Cudrania and Plecospermum differ from the other "genera" in their straight stamens.

On the basis of the similarities one may treat this group of taxa as rather distinct, but it appears premature to assign it the rank of genus.

The closest relatives of Cardiogyne africana appear to be Maclura brasiliensis (cf. Kaastra 1973) and Plecospermum spinosum.

b. The two very closely related species Chlorophora excelsa and $C$. regia differ in several characters from the above-mentioned group, for example in the lack of spines, the long stipules, the firm leaves, the spicate 

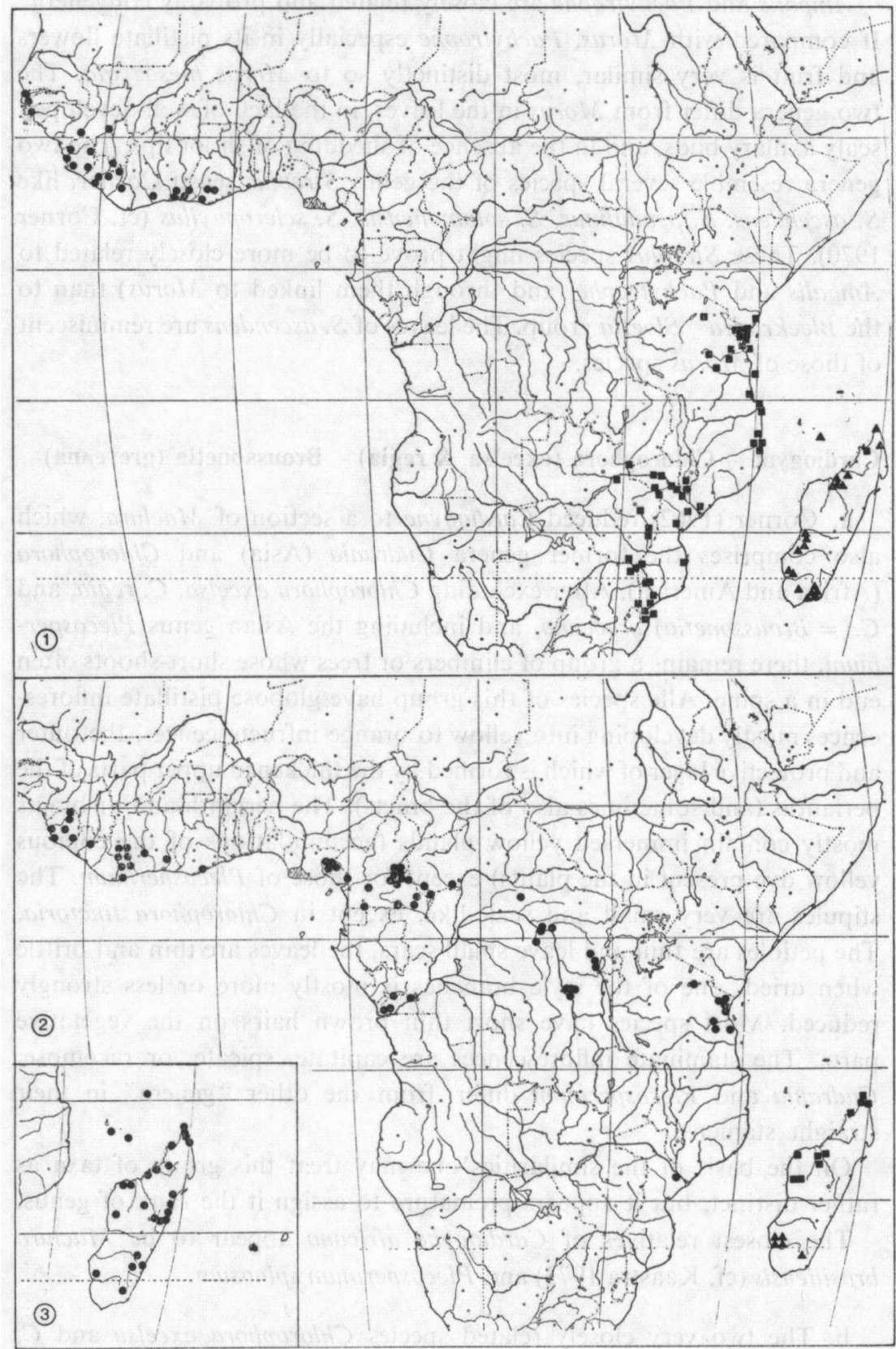

Fig. 15. - Distribution of some species of the Moreae : map 1, Chlorophora regia, - Cardiogyne africana, $\Delta$ Broussonetia greveana; map 2, Sloetiopsis usambarensis, - Bleekrodea madagascariensis, A Fatoua madagascariensis; map 3, 1 Maillardia borbanica, M. montana. 
pistillate inflorescences, the green infructescences, and the thin white pulpy exocarp. On the other hand there are also resemblances, but they are no more pronounced than those to Broussonetia or Morus. The closest relative of these two species might prove to be the neotropical Bagassa guianensis, sharing characters of habit, the conspicuously lenticellate bark, the striking differences between leaves of juvenile and adult specimens, the structure of the infructescences (globose in Bagassa), the pistillate flower, and the fruit. But Bagassa has straight stamens, in contrast to Chlorophora excelsa and $C$. regia.

c. Broussonetia greveana superficially resembles Chlorophora excelsa in the pistillate inflorescences. However, there are two important differences. In Broussonetia greveana the perianth of the pistillate flower is tubular and more or less irregularly lobed to dentate, in C. excelsa regularly 4-parted with distinct decussate-imbricate tepals. In Broussonetia the outer and protective layer of the infructescence is formed by the upper thickened parts of the bracts, but in $C$. excelsa chiefly by the thickened upper parts of the tepals. The genus Broussonetia can be dilimited by the two features mentioned for $B$. greveana. The fruits of $C$. excelsa and $B$. greveana are very similar. These, as well as those of the other Broussonetia species (as far as examined), C. regia, and Bagassa guianensis are small and have a thin white pulpy exocarp forming a short basal stipe. The seeds contain endosperm, the cotyledons are thin and the radicle is long. According to a plate in Seringa's work on Morus (1855), the fruit of Broussonetia papyrifera may have rather thick fleshy and dehiscent exocarps. This suggests that the fruits of Broussonetia and the other species mentioned above are morphologically related to the well-developed dehiscent pulpy exocarps of other Moreae. On the other hand, there are indications (cf. Corner 1962) that more or less thick (dehiscent) pulpy endocarps are widespread in Moraceae with free fruits.

\section{Maillardia}

Corner reduced Maillardia as well as the Asian genus Calpidochlamys to sections of Trophis, thus combining the genera in which the tepals of the pistillate flowers are almost completely connate and adnate to the fruit and the staminate flowers have inflexed stamens. Corner's decision might prove to be correct. Relying on Corner's description of the endocarp of Calpidochlamys (1962), this genus is probably the closest relative of Maillardia. In further considerations about the delimitation of a genus 
Trophis s.l. the neotropical genera Sorocea, Olmedia, and Clarisia should be included, also with consideration of anatomical characters.

\section{Treculia}

Like Maillardia, Treculia can easily be distinghuished from the other African Moreae by its distinct features of inflorescence and flowers. Treculia is very closely related to the Asian genus Parartocarpus. Inflorescences, infructescences, fruits, and seeds of the two genera are basically similar.

In summary one may cautiously and provisionally conclude: Bleekrodea is probably a good genus, related to Fatoua, Sloetia, Sloetiopsis, and possibly to some genera presently inserted in the Dorstenieae;

Fatoua is a good genus, related to Bleekrodea;

Sloetiopsis is probably congeneric with Sloetia, which may prove to include some of the species of Streblus sensu Corner;

Morus can be regarded as a distinct taxon, related to Ampalis and Pachytrophe, and through them linked to a part of the species of Streblus sensu Corner;

Ampalis and Pachytrophe are (probably) congeneric and show relationships (possibly below the rank of genus) to some members of Streblus sensu Corner, as well as to Morus (but possibly on the genus level);

Cardiogyne is closely related to and probably even congeneric with Maclura s. str., and besides closely related to Plecospermum, more distantly related to Chlorophora tinctoria and to Cudrania; Chlorophora excelsa and $C$. regia probably constitute a separate genus with more or less distinct relationships to Bagassa, Broussonetia, (Chlorophora tinctora, and Morus);

Broussonetia (with $B$. greveana) is a clear-cut genus, without very clear relationships to other genera;

Maillardia seems to be related to Calpidochlamys and possibly to Trophis; Treculia is very closely related to Paratocarpus;

finally, the genera Streblus and Maclura sensu Corner (1962) appear to be too heterogenous.

Key to the genera of the Moreae

1.a. Climbers, shrubs or treelets with spines; both staminate and pistillate inflorescences globose-capitate .......... 13. Cardiogyne

b. Trees, shrubs or herbs without spines : .......... 2 
2.a. Herbaceous to suffrutescent plants without latex; inflorescences normally bisexual, racemose to spicate; segments of the perianth of the staminate flower valvate; one of the style branches reduced (Madagascar) . . 16. Fatoua

b. Trees or shrubs with latex; inflorescences bisexual cymes or normally unisexual; segments of the staminate flower imbricate; style branches 2 and equal (one of them reduced in Chlorophora only) . . . . . . . . . .

3.a. Inflorescences bisexual, shortly branched cymes or sometimes unisexual; pistillate flower usually one, the perianth tubular and the ovary free; stamens 5 . . . . . . . . . . 15. Bleekrodea

b. Inflorescences normally unisexual (sometimes bisexual in Treculia but then the pistillate flower without perianth); inflorescences spicate, capitate, or the pistillate ones uniflorous, but then the perianth of the pistillate flower either with free tepals or tubular and fused with the overay; stamens 4 or less ... . . . . . . . . . . . . . . .

4.a. Often cauliflorous trees or shrubs; inflorescences globose-capitate to broadly clavate, subinvolucrate; pistillate flowers without a perianth; stamens usually less than 4 and straight; stipules fully amplexicaul ... 18. Treculia

b. Ramiflorous trees or shrubs; inflorescences spicate, capitate, or the pistillate ones uniflorous, not subinvolucrate; pistillate flowers with a perianth; stamens 4, inflexed; stipules semi-amplexicaul or lateral . . . . . . . .

5.a. Uncinate hairs present and abundant pistillate inflorescences uniflorous; tepals of pistillate flower and the ovary free; shrubs or treelets (African continent). . . . . . . . . 14. Sloetiopsis

b. Uncinate hairs lacking; pistillate inflorescences spicate or capitate, if uniflorous, then the perianth of the pistillate flower tubular and adnate to the ovary; trees or (in Madagascar) shrubs ............

6.a. Stipules subpersistent and reflexed; perianth of the pistillate flower tubular and ovary and fruit free (Madagascar) . . . . . 12. Broussonetia

b. Stipules caducous; perianth of the pistillate flower not tubular, if tubular, then the ovary and fruit adnate to the perianth ..........

7.a. Leaves trinerved to triplinerved, leaf margin crenate (African continent) . . . . . . . . . . . . 8. Morus

b. Leaves pinnately veined, leaf margin mostly entire or subentire, or (in juvenile specimens) dentate .............. 8

8.a. Stipules connate; pistillate inflorescences with $2-15$ flowers; ovary and fruit free; cotyledons unequal and conduplicate (Madagascar) . 9. Pachytrophe

b. Stipules free; pistillate inflorescences usually with more than 15 flowers, or with 1-2 flowers, but then the pistil and fruit adnate to the perianth; cotyledons equal or extremely unequal . . . . . . . . .

9.a. Leaves and perianths (almost) glabrous; pistillate inflorescences with $1-2$ flowers; ovary and fruit adnate to the perianth; cotyledons extremely unequal (Madagascar and other islands) ....... 17. Maillardia

b. Leaves and perianths more or less hairy; pistillate inflorescences with many flowers; ovary and fruit free; cotyledons equal and plane . . . . . 10

10.a. Stipules $0.5-5 \mathrm{~cm}$ long; style branches unequal or one of them lacking (African continent) ..................... Chlorophora

b. Stipules 1-3 mm long; style branches 2, equal (Madagascar) . 10. Ampalis

\section{Morus L., Sp. Pl. : 986 (1753). - Type species : M. alba L.}

Morus L. subg. Afromorus A. Chev., Rev. Bot. Appl. Agr. Trop. 29 : 70 (1949), invalidly published; Leroy, Rev. Bot. Appl. Agr. Trop. 29 : 482 (1949) \& Bull. Mus. Hist. Nat. Paris, ser. 2, 21 : 732 (1949).

Dioecious trees; shoot apices shed. Leaves distichous, trinerved to triplinerved; stipules free, almost lateral. Inflorescences usually solitary on 
the lower leafless nodes of new (short-)shoots arising from well developed scaly resting buds on wood of the previous season, pedunculate, bracteate; staminate inflorescences spicate, flowers many (to few), not very close together; perianth 4-parted, segments imbricate; stamens 4, inflexed, at anthesis bending outward elastically, anthers introrse; pistillode quadrangular; pistillate inflorescences capitate, with 5-15 flowers; perianth 4-parted; ovary free, style subterminal, stigmas 2 . In fruit the lower part of the enlarged perianth more or less succulent; exocarp thin-fleshy, thicker on the seed-bearing side, indehiscent, endocarp crustaceous with a woody plug towards the hilum; testa thin, with a slightly thickened elliptic part below the hilum, with few vascular bundles, endosperm present; embryo curved, cotyledons equal and flat, not enclosing the long radicle.

It is rather surprising to meet a member of the chiefly temperate genus Morus in the lowlands of Africa. It was described in 1909 as Morus mesozygia by Stapf on material from Ivory Coast and as Celtis lactea by Sim on material from Moçambique. In the Flora of Tropical Africa (Rendle 1916) Celtis lactea was put into the synonomy of Celtis kraussiana. In 1922 Mildbraed recognized C. lactea as a species of Morus, which resulted in the combination $M$. lactea. Since that time $M$. lactea and $M$. mesozygia were often treated as separate species. Chevalier (1949) reduced $M$. lactea to a variety of $M$. mesozygia. He and Leroy (1949) placed the African species in Morus subg. Afromorus, thus setting it (them) apart from the other Morus species.

M. mesozygia is indeed distinct because of the attractive and conspicuous leaf venation and the infructescences. The infructescences are reminiscent, also in details, of those of Pachytrophe more than of Morus species with infructescences resembling fruits of Rubus, or of the elongate infructescences of the neotropical $M$. insignis. But in the characters of the leaf (base, margin, and venation) it matches the other Morus species, as well as in the abortion and shedding of shoot apices and the relatively large, scaly, axillary resting buds. On the other hand, $M$. mesozygia seems to be distinct from other Morus species in its wood anatomical characters (Normand 1950). In these features it agrees with Chlorophora excelsa and C. regia (Brazier \& Franklin 1961).

Both the delimitation and the subdivision of the genus should be a subject of reconsideration when the position and relationships of Ampalis, Pachytrophe and several present members of Streblus s.l. (Corner 1962) are further studied (see p. 331). 
8.1. Morus mesozygia Stapf ex A. Chev. [Végét. Ut. Afr. Trop. Fr. 5 : 263 (1909) nomen], Journ. Bot. [Paris] 22 : 99 (1909); Hauman, Fl. Congo, Ruanda-Urundi 1 : 55 (1948); A. Chev., Rev. Bot. Appl. Agr. Trop. 29: 69 (1949). - Lectotype: Chevalier 16267, Ivory Coast, Zaranou (P; isotype K). - Fig. 16.

M. mesozygia var. sanda A. Chev., Rev. Bot. Appl. Agr. Trop. 29 : 71 (1949), invalidly published.

M. mesozygia var. colossea A. Chev., Rev. Bot. Appl. Agr. Trop. 29 : 71 (1949), invalidly published.

Celtis lactea Sim, For. Fl. Port. E. Afr.: 97, t. 96 (1909); Rendle in Prain, Fl. Trop. Afr. 6(2) : 4 (1916). - Type : Sim 5299, Moçambique, Quisico (K).

Morus lactea (Sim) Mildbr., Notizbl. Bot. Gart. Berlin 8 : 243 (1922); Leroy, Journ. Agr. Trop. Bot. Appl. 2 : 677, t. 6(1-6) (1955).

M. mesozygia var. lactea (Sim) A. Chev., Rev. Bot. Appl. Agr. Trop. 29: 72 (1949).

Trees up to $35 \mathrm{~m}$ tall or shrubs; latex white; leafy twigs 1-3 mm thick, sparsely white-puberulous mainly on the nodes, or glabrous. Leaves elliptic to oblong, sometimes to lanceolate or to suborbicular, broadest in or below the middle, sometimes above the middle, (almost) equilateral, $3-13 \mathrm{~cm}$ long, $2-8 \mathrm{~cm}$ broad, chartaceous to subcoriaceous, acuminate to caudate or to subacute, at the base obtuse, truncate, emarginate, or cordate; margin crenate to serrate, at least in the upper part of the lamina; above short-pubescent at the base of the main veins, beneath on the lower part and in the axils of the main veins; veins slightly prominent to plane above, slightly prominent beneath; at the base trinervate, 3-6 smaller secondary veins arising from the upper part of the costa, tertiary veins towards the margin and the parallel ones between the main veins almost horizontal; petioles $8-20 \mathrm{~mm}$ long; stipules caducous, 4-5 $\mathrm{mm}$ long, membranous, sparsely puberulous to almost glabrous. Staminate inflorescences occasionally in pairs, spikes usually $1-2.5 \mathrm{~cm}$ long, ca. $0.8 \mathrm{~cm}$ in diam., sometimes interrupted; peduncle $3-20 \mathrm{~mm}$ long, (densely) white-puberulous; flowers many, occasionally few; perianth 2-3 mm high, membranous, ciliolate; filaments $3.5-4 \mathrm{~mm}$ long, anthers 1-1.2 mm long, 0.7-1 mm broad, connective rather small; pistillode ca. $0.5 \mathrm{~mm}$ high, apiculate; bracts differently shaped, flat, up to $1.5 \mathrm{~mm}$ long, membranous, ciliolate. Pistillate inflorescences subglobose, ca. $5 \mathrm{~mm}$ in diam.; peduncle 4-20 mm long, (densely) white-puberulous; flowers ca. 


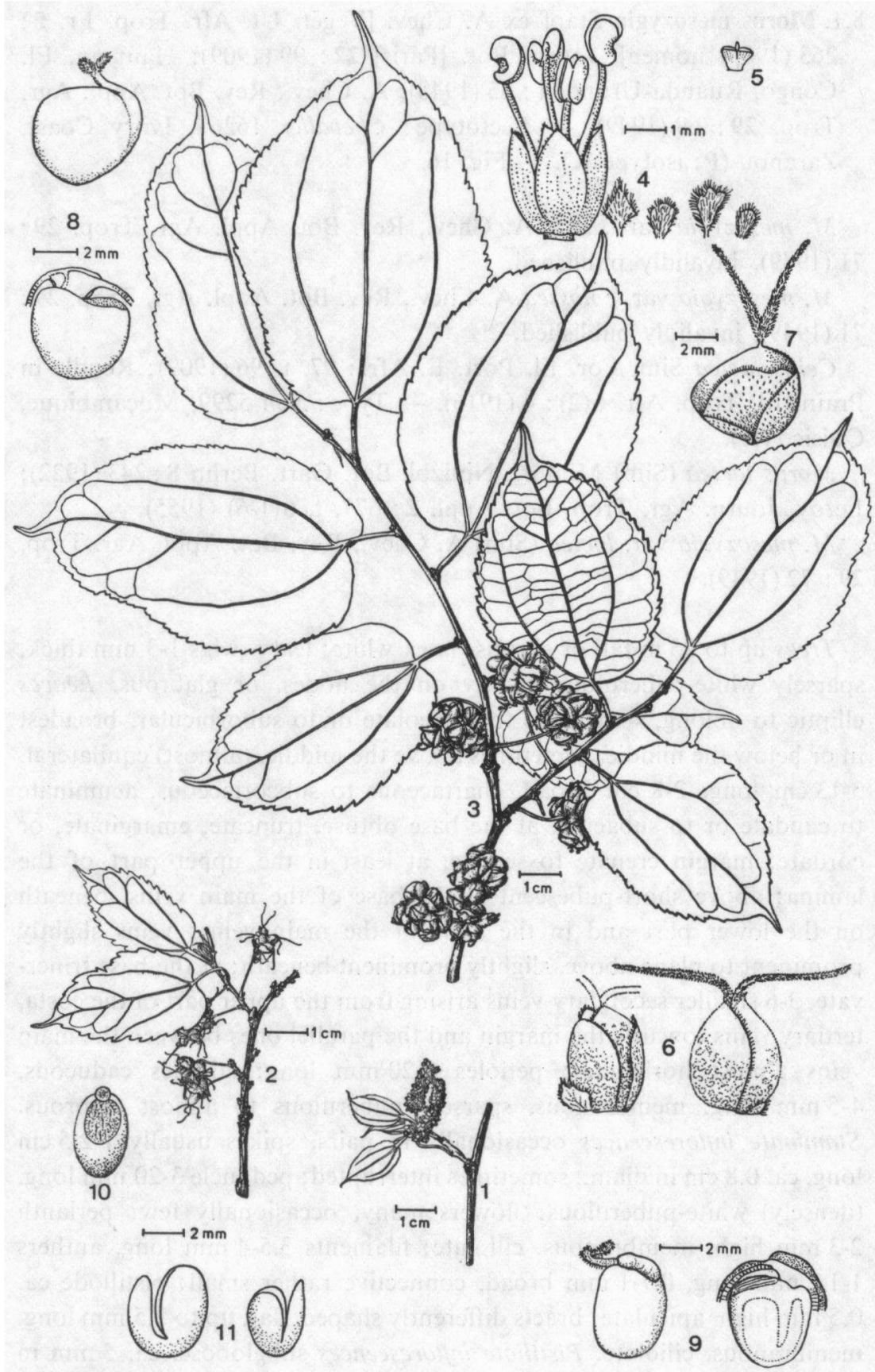

Fig. 16. - Morus mesozygia: 1 , leafy twig with staminate inflorescences; 2 , leafy twig with pistillate inflorescences; 3 , leafy twig with infructescences; 4 , staminate flower and bracts; 5 , pistillode; 6 , pistillate flowers and bracts; 7 , pistillate flower in fruit; 8, fruit; 9, fruit; 10, seed; 11, embryos (1: Simao 14; 2 : Fanshawe 9319; 3, 8-11: Simao 233; 4, 5 : Andrada 1447; 6 : Gomes e Sousa 1862; 7 : Esperito Santo 1961). 
$5-15$, mostly ca. 10 ; perianth ca. $2.5 \mathrm{~mm}$ high, tepals ciliolate; style 0.1 $0.2 \mathrm{~mm}$ long, stigmas filiform, $3-5 \mathrm{~mm}$ long, of the same or of different length, puberulous; bracts differently shaped, up to $1 \mathrm{~mm}$ long, ciliolate. Infructescences subglobose or sometimes somewhat elongate, ca. $1 \mathrm{~cm}$ in diam.; fruiting perianth succulent, yellowish to greenish; fruit ca. $5 \mathrm{~mm}$ long, $3-5 \mathrm{~mm}$ broad, more or less compressed; seed ca. $4.5 \mathrm{~mm}$ long, $2.5-4.5 \mathrm{~mm}$ broad, more or less compressed.

Distribution (fig. 14, map 1): In a probably discontinuous area ranging from Senegal to north-western Angola, south-western Ethiopia, and to northern Natal (Republic of South Africa); as evergreen trees in rain forests, but more usual, mostly as deciduous trees, in forests of drier regions, as in semi-deciduous forests, gallery forests, forests bordering savannas; often along streams or lakes, also in secondary forests or (left) as solitary trees after clearing of the forest; also planted (as shade tree) in villages or along streets (Ghana, Senegal); regionally rare to frequent; from sealevel to ca. $1250 \mathrm{~m}$.

Number of collections examined : ca. 140.

The flowering time(s) could not be established, except for Moçambique, where the (main) flowering time seems to be from September to November. As a rule the trees flower when they come into new foliage.

The greenish to yellowish infructescences with succulent fruiting perianths and exocarps are edible. The wood is said to be a good timber; it can be confused with that of Chlorophora excelsa, due to strong resemblances in habit, colour of the wood (yellow), and the conspicuously lenticellate bark.

According to data gathered in Kew, M. mesozygia was probably published before $C$. lactea.

Infra-specific taxa, as recognized by Chevalier (1949), are untenable. $M$. mesozygia is even a rather uniform species.

9. Pachytrophe Bur. in DC., Prodr. 17: 234 (1873); Benth. \& Hook., Gen. Pl. 3(1): 363 (1880); A. Richter, Term. Füzetek 18 : 294 (1895); Léandri, Mém. Inst. Sci. Madag., ser. B, 1 : 14 (1948); H. Perrier \& Léandri in Humbert, Fl. Madag. Moraceae : 9 (1952); Corner, Gard. Bull. Singapore 19: 214 (1962). - Lectotype species: P. dimepate Bur. 
Ampalis Boj. sect. Pachytrophe (Bur.) Baillon, Hist. Pl. 6 : 193 (18751876).

Dioecious trees. Leaves distichous, pinnately veined; stipules connate, semi-amplexicaul. Inflorescences usually in pairs in the leaf axils, spicate, pedunculate, bracteate, some of the bracts peltate, abaxial sterile groove present, flowers sessile, close together (in longitudinal rows); staminate inflorescences with many flowers, perianth 4-parted, segments decussateimbricate; stamens 4, inflexed, at anthesis springing back, anthers introrse; pistillode quadrangular; pistillate inflorescences with 2-14 flowers; perianth with 4 decussate-imbricate, free tepals; ovary free; style subapical; stigmas 2, of equal length. In fruit the perianth enlarged, more or less succulent and reddish; fruit basally adnate to the perianth, exocarp thinly fleshy, more thickly so on the seed-bearing side, indehiscent, endocarp crustaceous, with a large woody plug towards the hilum; testa thin, with an oblong to suborbicular not distinctly vascularized thickened part below the rather small hilum; embryo curved, cotyledons unequal, conduplicate, their tops inflexed, the larger enveloping the smaller; radicle rather long, enclosed by the cotyledons.

In 1873 Bureau described the genus Pachytrophe with two species, $P$. obovata and $P$. dimepate. Léandri (1948b) retained the two species and distinguished some varieties within the former. Material of Pachytrophe has been associated with and named under the Asian genus Plecospermum by Baillon (1895) and Richter (1895).

The two species were kept separate mainly on the basis of differences in the leaf shape and the leaf apex. Other differences than these could not be found. Although many specimens can be separated on their leaf characters, the occurrence of many intermediates and the nature of the differences do not justify separation on the specific level, and even not within one species. The differences in the leaves are probably (partly?) due to environmental conditions.

Pachytrophe is closely related to Ampalis and some species of Streblus sensu Corner (1962), and probably congeneric with them. These taxa are also distinctly related to Morus (see p. 331).

9.1. Pachytrophe dimepate Bur. in DC., Prodr. 17 : 234 (1873); Léandri, Mém. Inst. Sci. Madag., ser. B, 1 : 14, pl. (1948); H. Perrier \& Léandri in Humbert, Fl. Madag. Moraceae: 10, t. 2 (1952). - Lectotype: Chapelier s.n., Madagascar (P). - Fig. 17. 
P. obovata Bur. in DC., Prodr. 17 : 235 (1873); Léandri, Mém. Inst. Sci. Madag., ser. B, 1 : 16 (1948); H. Perrier \& Léandri in Humbert, Fl. Madag. Moraceae : 10, t. 2 (1952). - Type : Boivin 1717, Madagascar, Ile St. Marie (P).

Plecospermum bureaui A. Richter, Term. Füzetek 18 : 296 (1895), nom. nud. et superfl., with as synonym Plecospermum obovatum Bur., name on label of collection Boivin 1717.

Plecospermum? laurifolium Baillon in Grandidier, Hist. Madag., Bot., Atlas 3 : 294a (1895). - Type: Hildebrandt 3242, Madagascar, Nossi Komba (P).

Pachytrophe obovata var. laurifolia (Baillon) Léandri, Mém. Inst. Sci. Madag., ser. B, 1: 16 (1948); H. Perrier \& Léandri in Humbert, Fl. Madag. Moraceae : 11 (1952).

$P$. obovata var. montana Léandri, Mém. Inst. Sci. Madag., ser. B, 1 : 16 (1948); H. Perrier \& Léandri in Humbert, Fl. Madag. Moraceae : 11 (1952). - Lectotype: Ursch 32, Madagascar, Analamazoatra Forest (P).

Trees to $30 \mathrm{~m}$ tall, or shrubs; latex white; leafy twigs $0.5-2.5 \mathrm{~mm}$ thick, minutely puberulous, glabrescent. Leaves (subrotundate to) elliptic to oblong (to lanceolate), usually broadest in or above the middle, (1-)2(-16) cm long, (0.5-)1.5-6 cm broad, coriaceous to subcoriaceous, mostly acuminate to apiculate or obtuse, sometimes subcaudate or emarginate, at the base acute to obtuse; margin entire, often somewhat revolute; above and beneath glabrous or almost so; above the costa more or less impressed, especially towards the base, the other veins slightly prominent, beneath the costa prominent, the other veins less prominent to almost plane, 5-12(-16) pairs of secondary veins, without parallel tertiary veins; petioles $3-15(-20) \mathrm{mm}$ long, minutely puberulous to almost glabrous; stipules connate, $2-6(-9) \mathrm{mm}$ long, sparsely to rather densely minutely puberulous. Staminate inflorescences $0.5-5 \mathrm{~cm}$ long, including the $1-5 \mathrm{~mm}$ long, puberulous peduncle, rather densely flowered; perianth 1-5-2 $\mathrm{mm}$ high, membranous, puberulous and ciliolate, tepals almost equal; filaments $2.5-3.5 \mathrm{~mm}$ long, anthers ca. $0.7-1.0 \times 0.7-1.0 \mathrm{~mm}$, connective small, more or less gland-like swollen; pistillode ca. $0.5 \mathrm{~mm}$ high; bracts basally attached to peltate up to ca. $1 \mathrm{~mm}$ long or in diameter, puberulous and ciliolate. Pistillate inflorescences $0.5-2.5 \mathrm{~cm}$ long, including the $2-15 \mathrm{~mm}$ long, puberulous peduncle; flowers 2-14, perianth 1.5-2 mm high, tepals distinctly decussate, rather thick, their margins membranous, ciliolate, outside sparsely and minutely puberulous to 


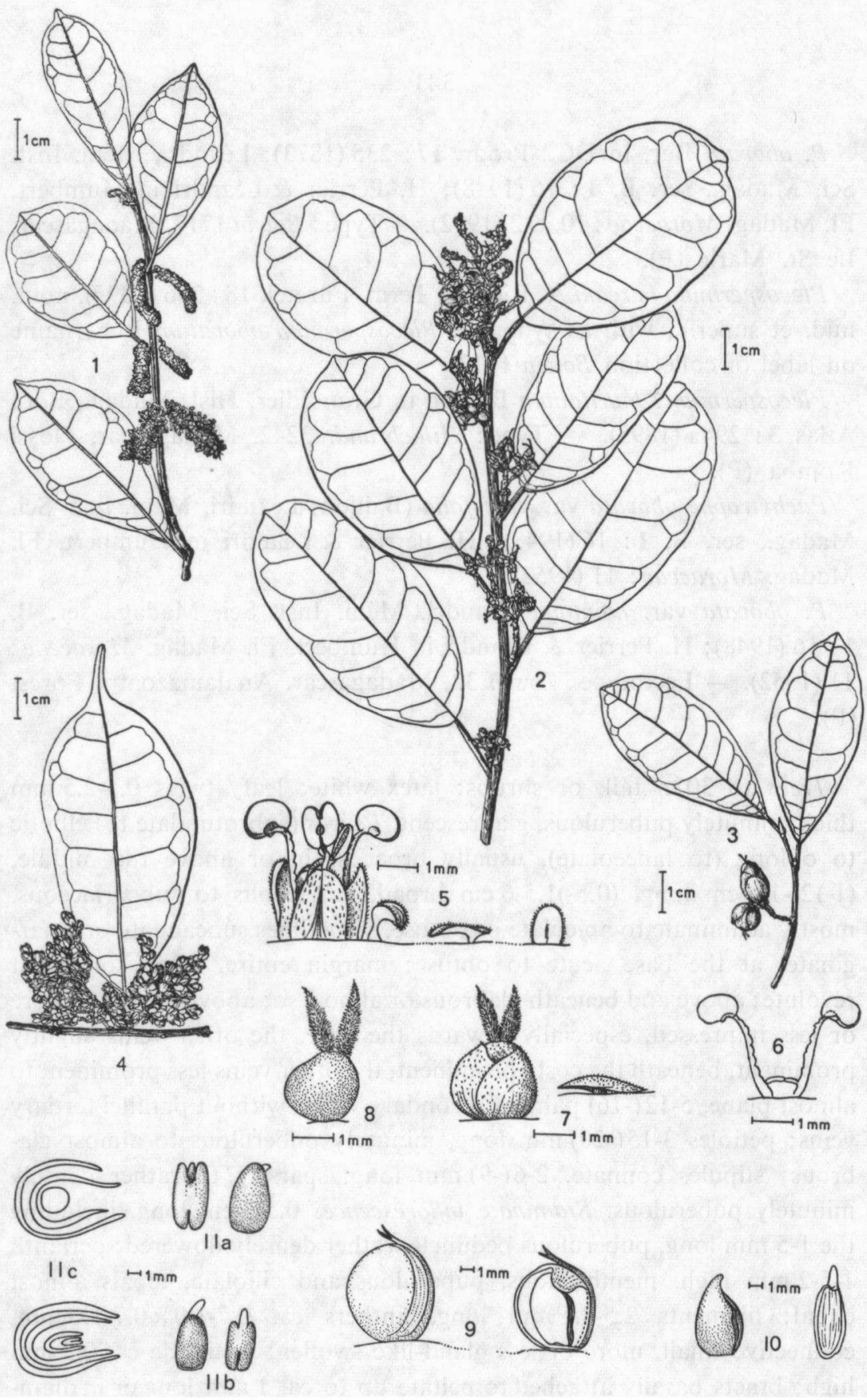

Fig. 17. - Pachytrophe dimepate: 1, leafy twig with staminate inflorescences; 2, leafy twig with pistillate inflorescences; 3 , leafy twig with infructescence; 4 , leafy twig with aberrant inflorescences; 5 , staminate flower and bracts; 6 , stamens and pistillode; 7, pistillate flower and bract; 8, pistil; 9, fruit; 10, seed and embryo; 11, a, outer, b, inner cotyledons, c, cross sections (1: Ursch 32; 2 : Capuron 27182; 3 : 9-11: Capuron 8894; 4: Serv. For. Madag. 12500; 5, 6: Capuron 941; 7, 8: Perrier de la Bâthie 9729). 
almost glabrous; ovary ca. $1.5 \mathrm{~mm}$ high, style $0-1.5 \mathrm{~mm}$ long, stigmas ca. 1.5-3 mm long, more or less densely puberulous; bracts crowded on the upper part of the peduncle and among the flowers, peltate (or subpeltate), up to $2.5 \mathrm{~mm}$ in diameter, sparsely minutely puberulous and ciliolate. In fruit perianth ca. 6-8 $\mathrm{mm}$ high, the succulent tepals striate (in herbarium material); fruit 5-8 $\mathrm{mm}$ high, $6-7 \mathrm{~mm}$ broad; seed ca. 4-5 $\mathrm{mm}$ long, the indistinctly vascularized part of the testa dark brown, in the spaces between the parts of the embryo membranous to mucilaginous material connected with the thickened part of the testa (probably remains of endosperm).

Distribution (fig. 14, map 1): Madagascar, confined to the eastern and north-western part of the island; as evergreen or deciduous trees or shrubs in humid to dry forests (or thickets), often by streams or the seashore; often on sand; from sealevel to $1000 \mathrm{~m}$.

Number of collections examined : ca. 170.

Flowering probably throughout the year, with a peak from September to March.

The infructescence with reddish succulent perianths and exocarps are edible. The hard wood is used for carpentry.

The species may occasionally be epiphytic or liana-like.

Several specimens bear strange paniculate structures consisting of strongly branched short twigs bearing coriaceous persistent scales (probably modified stipules), among which once a seedless fruit was found. Often the ovaries do not develop into fruits.

10. Ampalis Boj., Hort. Maurit.: 291 (1837); Bur. in DC., Prodr. 17: 250 (1873) ; Baillon, Hist. Pl. 6: 190 (1875-1876); Benth. \& Hook., Gen. Pl. 3(1) : 365 (1880); Léandri, Mém. Inst. Sci. Madag., ser. B, 1 : 9 (1948); Corner, Gard. Bull. Singapore 19: 214 (1962). - Type species : $A$. mauritiana (Jacq.) Urb.

Streblus Lour. subgen. Parastreblus Blume, Mus. Bot. Ludg.-Bat. 2 : 80 (1956). - Type species: S. mauritianus (Jacq.) Blume [= Ampalis mauritiana (Jacq.) Urb.].

Dioecious trees. Leaves in spirals or mostly (almost) distichous, pinnately veined; stipules free, almost lateral. Inflorescences solitary or 
in pairs in the axils of the leaves, spicate, pedunculate, with (rather) few bracts; flowers sessile, close together in longitudinal rows, sterile groove present; perianth of the staminate flowers 4-parted, segments decussate-imbricate; stamens 4 , inflexed, at anthesis springing back, anthers introrse; pistillode quadrangular; pistillate flowers with 4 free, decussate-imbricate, two by two different tepals; ovary free; stigmas 2 , of equal length. In fruit perianth enlarged, more or less succulent (and greenish white?); exocarp thin, fleshy, thicker at the seed-bearing side, indehiscent; endocarp crustaceous, with a woody plug towards the hilum; testa rather thin, with an oblong, thickened, not distinctly vascularized part below the rather small hilum; embryo with equal, rather thick, almost plane cotyledons; radicle long.

Ampalis mauritiana was first described as Morus mauritiana by Jacquin (1791), probably on material from Mauritius, where the species was introduced long ago. Material from Mauritius also served for Morus nitida, described by Willemet (1796). Under the genus Morus the species has also been described as $M$. ampalis [by Poiret (1797) on material from Madagascar] and as $M$. rigida [by Hasskarl (1844) on material grown in the botanical garden of Bogor]. The species has been associated with Trophis (cf. Roxburgh 1832) and with Streblus (Blume 1856). The genus Ampalis was established by Bojer (1837) by separating $M$. mauritiana and $M$. ampalis from Morus and uniting them under $A$. madagascariensis.

Ampalis is very closely related to Pachytrophe. The only difference of some importance is to be found in the stipules: fused in Pachytrophe, free in Ampalis. The flowers and fruits are similar to those of Morus mesozygia; in the elongate inflorescences it is reminiscent of the neotropical Morus insignis. Furthermore, A. mauritiana shows distinct resemblances to species of Streblus sensu Corner (1962) (see p. 330).

The cotyledons apparently lie in a plane transverse to those of Pachytrophe. But observation of the attachment of the cotyledons shows the position of the embryo to be similar in the two taxa.

10.1. Ampalis mauritiana (Jacq.) Urb., Symb. Antill. 8 : 165 (1920). Type : Jacquin, Ic. Pl. Rar. 3 : t. 617 (1789). - Fig. 18.

Morus mauritiana Jacq., Collect. 3 : 206 (“ 1789”, 1791); Poir. in Lam., Encyl. Bot. 4 : 381 (1797); Willd., Sp. Pl. 4 : 371 (1805); Spreng., Syst. Veg. 1 : 492 (1825).

Streblus mauritianus (Jacq.) Blume, Mus. Bot. Lugd.-Bat. 2 : 80 (1856). 
S. maritimus Palacky, Catal. Pl. Madag. 2: 31 (1907), probably a mistake in writing or printing $S$. mauritianus $\mathrm{Bl}$.

Morus nitida Willem. in Usteri, Ann. Bot. 18 : 56 (1796). - Type : not yet traced.

M. ampalis Poir. in Lam., Encycl. Bot. 4 : 380 (1797); Willd., Sp. PI. 4 : 371 (1805); Spreng., Syst. Veg. 1 : 492 (1825). - Syntypes: ex herb. Poiret s.n., Madagascar and Réunion (P).

Trophis cylindrica Roxb. in MSS, as synonym of Morus mauritiana cited in Roxb., Fl. Indica 3 : 599 (1832).

Ampalis madagascariensis Boj., Hort. Maurit. : 291 (1837), based on and as synonym of Morus mauritiana and M. ampalis; Bur. in DC., Prodr. 17: 251 (1873); Baillon in Grandidier, Hist. Madag., Bot., Atlas 3 : t. 293 (1895); Léandri, Mém. Inst. Sci. Madag., ser. B, 1 : 9, with plate (1948); H. Perrier \& Léandri in Humbert, Fl. Madag. Moraceae: 8, t. 2 (1952).

A. madagascariensis var. occidentalis Léandri, Mém. Inst. Sci. Madag., ser. B, 1 : 12, pl. (1948); H. Perrier \& Léandri in Humbert, Fl. Madag. Moraceae : 9 (1952). - Lectotype: Perrier de la Bâthie 17402, Madagascar, Manambolo River, affluent of the Upper Betsiboka River (P; isotype $\mathrm{K}$ ).

Morus rigida Hassk., Cat. Hort. Bog. : 74 (1844) \& PI. Jav. Rar.: 198 (1848). - Type : $M$. rigida was possibly described from living material in the botanical garden of Bogor; several collections of the plants in Bogor have been made after the date of publication (e.g., several collections made by Teysmann).

Dioecious trees up to $15(-20) \mathrm{m}$ tall, or shrubs; latex white; leafy twigs 1-6 mm thick, (in herbarium material the younger parts often more or less compressed and sulcate), rather conspicuously lenticellate, puberulous to hispidulous to scabrous. Leaves elliptic to oblong (to lanceolate), broadest in or mostly above the middle, $2-16 \mathrm{~cm}$ long, $1-8 \mathrm{~cm}$ broad, coriaceous to subcoriaceous, acuminate to obtuse, sometimes to emarginate, at the base acute to obtuse; margin callose and often somewhat revolute, entire, probably only in juvenile specimens pinnately lobed to parted; both surfaces scabrous (with short rigid hairs) to smooth and glabrous; above veins slightly prominent or the main veins more or less impressed, beneath veins prominent, 5-10 pairs of secondary veins, without parallel tertiary veins; petioles $3-15(-22) \mathrm{mm}$ long, puberulous to hispidulous to scabrous or glabrous; stipules 1-3 mm long, chartaceous, minutely puberulous. Staminate inflorescences often on the leafless basal 


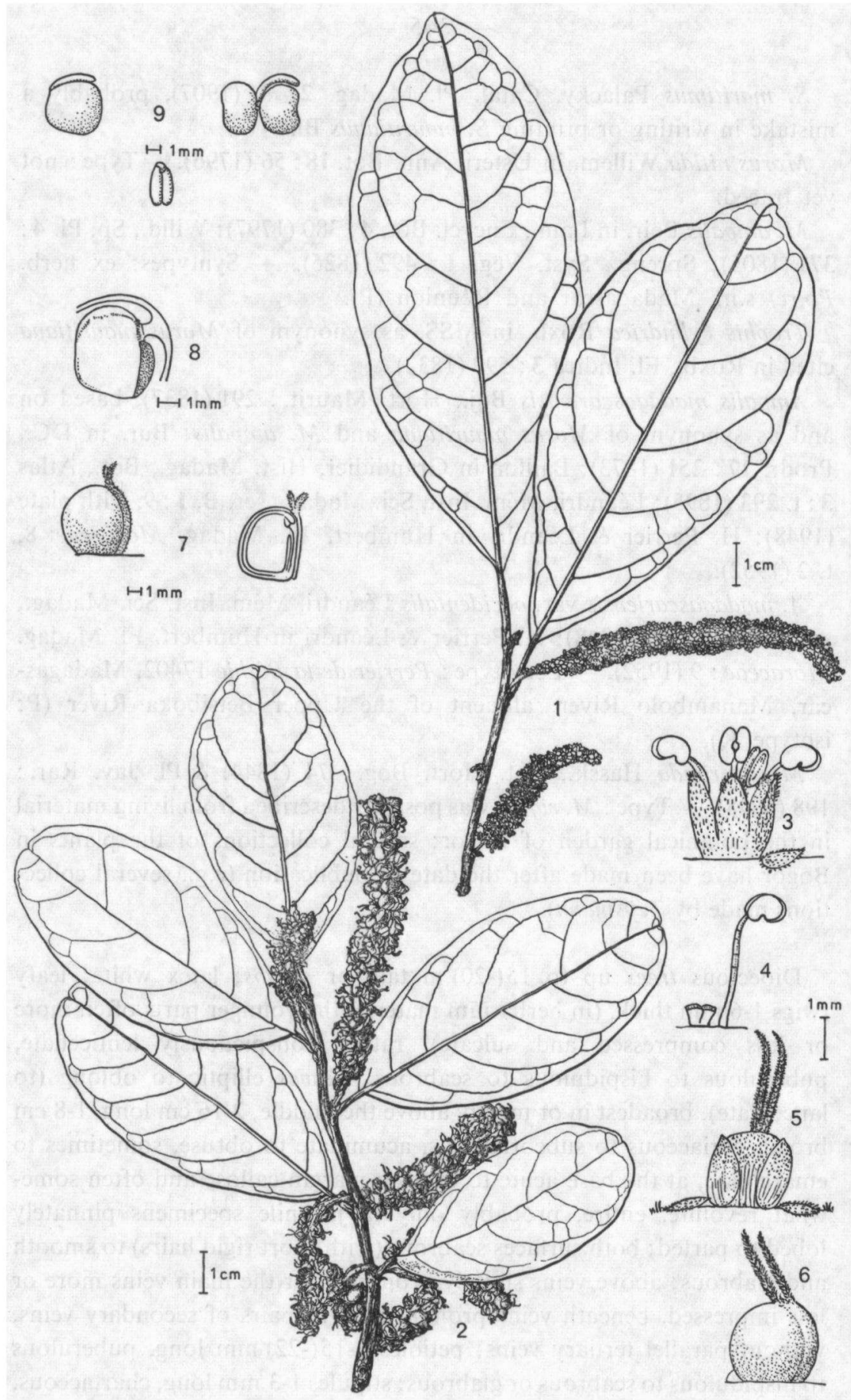

Fig. 18. - Ampalis mauritiana: 1, leafy twig with staminate inflorescences; 2, leafy twig with pistillate inflorescences; 3 , staminate flower and bract; 4, stamen and pistillode; 5 , pistillate flower and bracts; 6 , pistil; 7 , fruit; 8 , seed; 9 , embryo (1: Capuron 18494; 2 : Capuron 234; 3, 4 : Humblot 367; 5, 6: Capuron 27147; 7-9: Serv. For. Madag. 6615). 
part of new shoots, ca. $2-9 \mathrm{~cm}$ long including the $2-10 \mathrm{~mm}$ long, usually bracteate, puberulous to hirtellous peduncle; rachis puberulous; perianth $1.5-2 \mathrm{~mm}$ high, membranous, sparsely to rather densely puberulous with short rigid hairs with a broadened base, at the apex usually rather densely ciliolate with softer white hairs; filaments $2.5-3.5 \mathrm{~mm}$ long, anthers ca. $0.8-1.2 \times$ ca. $0.8-1.2 \mathrm{~mm}$; pistillode ca. $0.5 \mathrm{~mm}$ high, quadrangular; bracts basally attached to subpeltate, elliptic to oblong, up to $1.5 \mathrm{~mm}$ long, thicker than the perianth, sparsely puberulous and/or ciliolate to almost glabrous. Pistillate inflorescences usually solitary, sometimes paired, often on the leafless basal part of new shoots, (1-)1.5-12 cm long including the $5-20 \mathrm{~mm}$ long, usually bracteate, puberulous to hirtellous peduncle; rachis puberulous to hirtellous; flowers in the basal part of the rachis usually in one row and sometimes reduced, higher usually in 3 rows; perianth $1.5-2.5 \mathrm{~mm}$ high, tepals distinctly decussate, the inner ones often somewhat larger than the outer ones, rather thick but with a membranous margin, sparsely puberulous; ovary ca. $2 \mathrm{~mm}$ high, stigmas 1.5-3 mm long, rather densely puberulous; bracts rather few, scattered on the peduncle and the rachis, (sub)peltate, up to ca. $1 \mathrm{~mm}$ in diam., almost glabrous. Fruiting perianth ca. $5 \mathrm{~mm}$ high, the more or less succulent tepals (in herbarium material) striate; fruit ca. 4.5-5 $\times 5-6 \mathrm{~mm}$; seed ca. $4 \times 4 \mathrm{~mm}$; the thickened, not distinctly vascularised part of the testa dark brown.

Distribution (fig. 14, map 2): Madagascar, mainly in the eastern part of the island, also in Mayotte (Comoro Islands); as evergreen muchbranched shrubs or trees in dry to humid forests, mostly along streams, by sea coasts or lake sides, often on sandy soils, from sealevel to ca. $1500 \mathrm{~m}$ altitude; also cultivated. Introduced in Mauritius, Java (Bot. Gard. Bogor), India (Bot. Gard. Calcutta), Martinique, and Trinidad.

Number of collections examined : ca. 105.

Flowering probably throughout the year, but mainly from October to February.

The infructescences with succulent fruiting perianths and exocarps are edible.

11. Chlorophora Gaudich. in Freyc., Voy. Monde Bot.: 508 (1830); Benth. \& Hook., Gen. Pl. 3(1): 363 (1880); Kaastra, Acta Bot. 
Neerl. 21 : 657 (1972) \& $22: 69$ (1973). - Type species : C. tinctoria (L.) Gaudich. ex Benth. \& Hook.

Maclura Nutt. sect. Chlorophora (Gaudich.) Baillon, Hist. Pl. $6: 193$ (1875-1876); Corner, Gard. Bull. Singapore 19 : 236 (1962).

Dioecious trees. Leaves distichous, pinnately veined; stipules free, not fully amplexicaul. Inflorescences usually solitary in the axils of the leaves or on leafless nodes at the base of fertile twigs, spicate, pedunculate; flowers numerous in close longitudinal rows alternating with rows of basally attached bracts, abaxial sterile groove present; perianth of the staminate flower 4-parted, segments imbricate; stamens 4, inflexed, at anthesis bending outward elastically, anthers introrse; pistillode quadrangular or applanate and bidentate; perianth of the pistillate flowers 4-parted, segments decussate-imbricate, two by two differently shaped; ovary free, stigmas 2 , usually one of them more or less reduced or lacking. In fruit the perianth enlarged and somewhat thickened; fruit stipitate and slightly compressed; exocarp thin, white, fleshy, thicker at the narrowed base and at the seed-bearing side, indehiscent; endocarp crustaceous with a small woody plug towards the hilum; testa thin with a slightly thickened ovate vascularized part below the hilum; endosperm present; embryo curved, cotyledons small, flat, equal, not enclosing the long radicle.

In 1869 Welwitsch described Morus excelsa. This species was referred to Maclura by Bureau (1873) and to Chlorophora by Bentham \& Hooker (1880). Under Chlorophora some additional African species were described : C. tenuifolia (Engler 1898), C. alba (Chevalier 1912) and C. regia (Chevalier 1912). The first two proved to be synonyms of $C$. excelsa (cf. Rendle 1916). The same species was also described as Milicia africana by Sim (1909) and thus associated with Cardiogyne africana (= Milicia spinosa Sim). Chlorophora, composed of African and American species, was reduced to a section of Maclura by Corner (1962).

As discussed above (p. 331, 333), the broad genus Maclura has to be accepted with much reserve. A definite conclusion about the position of the two African species can only be reached after further study of Maclura s.l. and comparison with Bagassa, Batocarpus, Morus, and Broussonetia. At first sight the two species resemble the Madagascan Broussonetia greveana (formerly Chlorophora greveana), but they differ distinctly in the perianth of the pistillate flower and the infructescences (see p. 333). 
C. excelsa and $C$. regia are very closely related, as shown by the fact that the initial doubt about the existence of two species faded only gradually. They are very similar in most morphological characters and also in their wood anatomy (Brazier \& Franklin 1961). In adult specimens the only differences can be found in the leaf venation and the indument. Juvenile specimens of both species can be told apart by differences in the indument of the leaves and in the colour of the costa beneath which is usually red in $C$. regia and yellow in $C$. excelsa. The leaves of juvenile specimens differ in shape, margin, venation, texture, and indument from those of adult specimens. Another difference between juvenile specimens of the two species can be found in the growth habit. C. excelsa shows sympodial growth and bears its leaves biserially even on the stem. $C$. regia shows monopodial growth. The stem bears spirally arranged leaves. Branches with distichous leaves are horizontal and arise in continuous order (cf. Hallé \& Oldeman 1970). When becoming adult, $C$. regia probably attains the same growth habit as $C$. excelsa. In West Africa the species are sympatric. There they may occur side by side in the same habitats and flower (almost) simultaneously. Both are light demanders (cf. Aubréville 1959; Voorhoeve 1965). When young both Chlorophora species are attacked by the parasite Phytoloma, but probably not by the same species (cf. White 1966).

\section{Key to the species of Chlorophora}

1.a. The areoles on the lower leaf surface covered by short white hairs; 10-20 pairs of secondary veins . . . . . . . . . . . 1. C. excelsa

b. The areoles on the lower leaf surface not covered by hairs; 7-11(-14) pairs of secondary veins .............. 2. C. regia

11.1. Chlorophora excelsa (Welw.) Benth. \& Hook., Gen. Pl. 3(1): 363 (1880); Rendle in Prain, Fl. Trop. Afr. 6(2): 22 (1916); De Wild., Ann. Mus. Congo, Bot., ser. 5, 3: 63 (1909); Andrews, Flow. Pl. Anglo-Egyptian Sudan 2: 257, t. 90 (1952); Aubrév., Fl. For. Côte d'Ivoire 1: 49, t. 4 (1959). - Type: Welwitsch 1559 오, Angola, Golungo Alta, Dembos, Cazengo (LISU; isotypes B, BM, G, K, P; the collection also contains ${ }^{t}$ and juvenile material). - Fig. 19.

Morus excelsa Welw., Trans. Linn. Soc. Lond. (Bot.) 27: 69, t. 23 (1869).

Maclura excelsa (Welw.) Bur. in DC., Prodr. 17 : 231 (1873); Corner, Gard. Bull. Singapore 19: 237 (1962). 


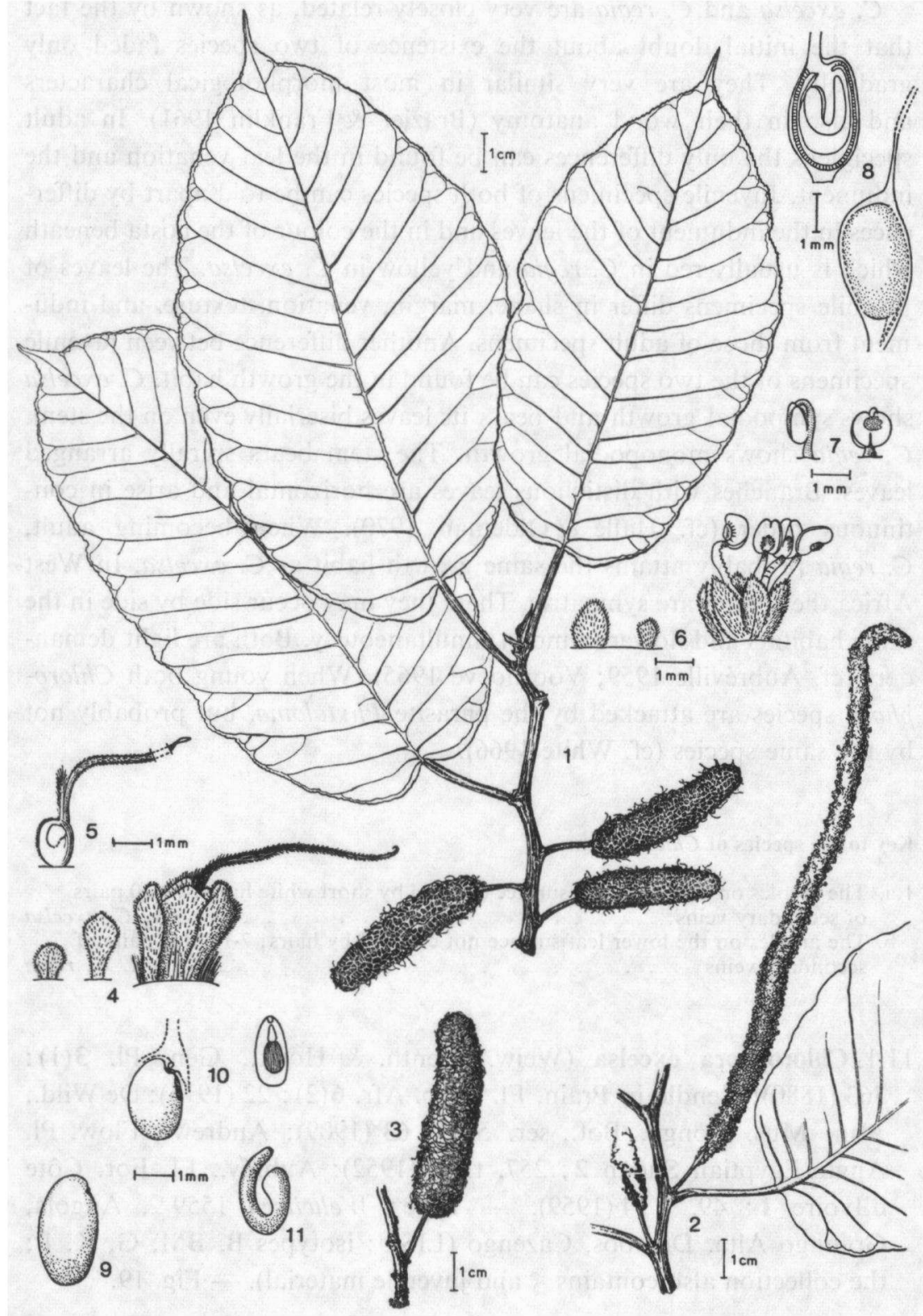

Fig. 19. - Chlorophora excelsa : 1, leafy twig with pistillate inflorescences; 2 , staminate inflorescence; 3 , infructescence; 4 , staminate flower; 5 , stamens and pistillode; 6 , pistillate flower and bracts; 7 , pistil; 8, fruit ; 9 , endocarp body; 10, seed; 11 , embryo (1: Simão 152; 2: Barbosa 2611; 3: Torre \& Paiva 9372; 4, 5: Barbosa 2278; 7 : J. Léonard 1049: 8, 9 : J. Léonard 1946; 10, 11 : Simão 654). 
Chlorophora tenuifolia Engl., Bot. Jahrb. 20: 139 (1894); Engl., Monogr. Afr. Pfl. 1(Moraceae) : 4 (1898); Engl., Pflanzenw. Afr. 3(1): 21 (1915). - Type : Quintas 154, Såo Tomé (COI; isotype LISU).

Milicia africana Sim, For. Fl. Port. E. Afr. : 97, t. 122 (1909). — Type : Sim 5386, Moçambique (not yet traced).

Chlorophora alba A. Chev., Bull. Soc. Bot. Fr. 58(Mém. 8d) : 209 (1912). - Type : Chevalier 24236, Dahomey, Kouandé (P; isotype K).

Dioecious (or sometimes monoecious?) trees up to $35(-50) \mathrm{m}$ tall; latex white or yellowish; leafy twigs $0.5-6 \mathrm{~mm}$ thick, white-puberulous, pubescent or almost glabrous, the lower part of new shoots with short internodes and often only scale-leaves. Leaves elliptic to oblong (to lanceolate), $6-20(32) \mathrm{cm}$ long, $3.5-10(-12) \mathrm{cm}$ broad, usually broadest in or below the middle, chartaceous to coriaceous, mostly distinctly inequilateral, mostly short-acuminate to mucronate, sometimes subacute or subcaudate, at the base obtuse to cordate, occasionally acute; margin entire to faintly repand or crenate; above puberulous or scabridulous and then often pubescent on the main costa veins and the proximal parts of the secondary veins, or (almost) glabrous, beneath on the main veins puberulous, pubescent, or almost glabrous, the areoles covered with short weak hairs inserted on the lateral sides of the veinlets; veins nearly plane above, more or less prominent beneath, 10-22 pairs of secondary veins, with parallel tertiary veins; petioles $1-5 \mathrm{~cm}$ long; stipules $0.5-5 \mathrm{~cm}$ long, (membranous to) chartaceous to subcoriaceous, those forming the buds coriaceous, rather sparsely white-puberulous to pubescent, usually leaving conspicuous white hairy scars. Staminate inflorescences $8-20 \mathrm{~cm}$ long, ca. $5 \mathrm{~mm}$ in diam.; peduncle $8-23 \mathrm{~mm}$ long, white-puberulous to pubescent to subtomentose, often with some large bracts on the upper part; perianth ca. $1.5 \mathrm{~mm}$ high, tepals almost equal, convex, puberulous to pubescent or to tomentellous; filaments $1.5-2 \mathrm{~mm}$ long, anthers 0.7-0.9 mm long, ca. $0.6 \mathrm{~mm}$ broad, connective rather small; pistillode membranous, $0.3-0.5 \mathrm{~mm}$ high; bracts ovate to spathulate, up to $1 \mathrm{~mm}$ long, puberulous. Pistillate inflorescences $2-3 \mathrm{~cm}$ long, $5-6 \mathrm{~mm}$ in diam.; peduncle 7-20 mm long, white-puberulous to pubescent to subtomentose; perianth 2-2.5 mm high, the inner tepals flat, the outer ones subconduplicate-cucullate, puberulous to pubescent or to tomentellous; ovary ca. $1 \mathrm{~mm}$ high, one stigma 3-7 mm long, the other 0.1-1 mm long; bracts (sub)spathulate, membranous, $0.5-1.5 \mathrm{~mm}$ long, puberulous. Infructescences $3-5 \mathrm{~cm}$ long, $1.5 \mathrm{~cm}$ in diam.; fruiting perianth $6-7 \mathrm{~mm}$ high, tepals somewhat thickened; fruit $2.5-3 \mathrm{~mm}$ long; seed ca. $2 \mathrm{~mm}$ long. 
Juvenile specimens : Leafy twigs white-hirtellous to pubescent to (sub) tomentose; the leaves lanceolate to oblong, chartaceous, the apex longacuminate to subcaudate or to subacute, the base obtuse to subcordate or to cordate, the margin serrato-dentate to crenato-dentate, above strigillose to puberulous or to hispidulous, often more or less scabrous, on the main veins often pubescent to tomentose, beneath hirtellous to sparsely or densely tomentose; the stipules puberulous to pubescent.

Distribution (fig. 14, map 2): From Guinea-Bissau to Moçambique; in deciduous, semi-deciduous, or evergreen (primary and secondary) forests, apparently with preference for the drier types of forests, often in gallery forests, in forest islands in savanna regions, or there as lone trees: occasional to predominant; from sealevel to ca. $1300 \mathrm{~m}$. Trees of $C$. excelsa can often be found as lone trees in cultivated areas. For some regions (with mixed forests) the trees are reported to be deciduous for a short period, due to dry seasons (cf. Vigne 1931; Hutchinson \& Dalziel 1937; Aubréville 1959).

Number of collections examined : ca. 220.

From West Africa to the Sudan (and Uganda) flowering from January to March; in East Africa (from Moçambique to Uganda) from July to December, with a peak in August and September, which also holds for some parts of Zaire, Gabon, and São Tomé. Deciduousness is correlated with flowering time.

The species is a valued timber; bark and latex are used for several purposes. A survey of the use of the species is given in the Useful Plants of West Tropical Africa, Hutchinson \& Dalziel (1937) (see also Vigne 1931).

Young trees (often attacked by the gall-forming Phytolyma lata) have a continuous growth. The growth of adult trees is periodical, but apparently not quite synchronous and not strictly related to season and flowering time. Osmaton (1965) reported the occurrence of monoecious trees in Uganda. He contradicted the statement of Lawton (1955) that male and female trees are different in habit.

Bats and birds seem to play an important part in the dispersal (Osmaston 1965; Dale \& Greenway 1961). The fallen infructescences attract small antelopes and rodents (Vigne 1931). 
11.2. Chlorophora regia A. Chev., Bull. Soc. Bot. Fr. 58(Mém. 8d) : 209 (1912); Rendle in Prain, Fl. Trop. Afr. 6(2): 23 (1916); Gomes \& Sousa, Mem. Soc. Brot. 1 : 74, t. 37 (1930) \& Ess. Florestais Guiné Port. 4 : 1-14, pl. (1956); Aubrév., Fl. For. Côte d'Ivoire 1 : 49, t. 4 (1959); Voorhoeve, Liberian High Forest Trees : 285, t. 54, phot. 23 (1965). - Type : Chevalier 12505bis, Guinea, Fouta-Djalon, between Mamou and Timbo (P, not seen). - Fig. 20.

Maclura regia (A. Chev.) Corner, Gard. Bull. Singapore 19 : 237 (1962).

Trees up to $35 \mathrm{~m}$ tall; latex white; leafy twigs $1-4 \mathrm{~mm}$ thick, sparsely white-puberulous, the lower part of new shoots with short internodes and often leafless (only stipules). Leaves oblong to elliptic, broadest in or below the middle, more or less inequilateral, $4-20(-28) \mathrm{cm}$ long, $3-13 \mathrm{~cm}$ broad, chartaceous to subcoriaceous, shortly acuminate to mucronate, at the base obtuse to cordate; margin almost entire, repand or crenatodenticulate towards the apex; above glabrous or nearly so, beneath sparsely puberulous on the veins; veins slightly prominent to plane above, more or less prominent beneath; 7-11 (-14) pairs of secondary veins, most tertiary veins parallel, petioles $8-36 \mathrm{~mm}$ long, puberulous; stipules 1-3.5 $\mathrm{cm}$ long, membranous to chartaceous (those forming the buds coriaceous), puberulous. Staminate inflorescences $8-18 \mathrm{~cm}$ long, 5-6 $\mathrm{mm}$ in diam.; peduncle $8-18 \mathrm{~mm}$ long, densely white-puberulous to tomentellous; perianth ca. $1.5 \mathrm{~mm}$ high, tepals almost free, membranous, puberulous to tomentellous; filaments ca. $3 \mathrm{~mm}$ long, anthers $0.8-1 \mathrm{~cm}$ long, 0.5 $0.6 \mathrm{~mm}$ broad, connective rather small; pistillode ca. $0.5 \mathrm{~mm}$ high, membranous; some bracts $2-3 \mathrm{~mm}$ long and ovate to elliptic, others 1-2 mm long and oblong to (sub)spathulate, puberulous to tomentellous. Pistillate inflorescences $1-4.5 \mathrm{~cm}$ long, ca. $5 \mathrm{~mm}$ in diam.; peduncle 7-10 mm long, white-puberulous to tomentellous; the inner tepals flat to slightly convex, the outer ones subconduplicate-cucullate, the upper parts puberulous to tomentellous; style up to $0.5 \mathrm{~mm}$ long, one stigma 8-10 mm long and minutely puberulous, sometimes also the other stigma developed and up to $1 \mathrm{~mm}$ long; bracts $0.5-2 \mathrm{~mm}$ long, ovate, oblong to (sub)spathulate, puberulous to tomentellous. Infructescences up to $8 \mathrm{~cm}$ long, ca. $12 \mathrm{~mm}$ in diam., peduncle up to $16 \mathrm{~mm}$ long, perianth 5-6 $\mathrm{mm}$ high; fruit ca. $2.5 \mathrm{~mm}$ long; seed ca. $2 \mathrm{~mm}$ long.

Juvenile specimens: Leafy twigs puberulous; the leaves lanceolate to oblong, chartaceous, the apex long-acuminate, the base obtuse to cordate, the margin serrato-dentate to crenato-dentate, above puberulous to 


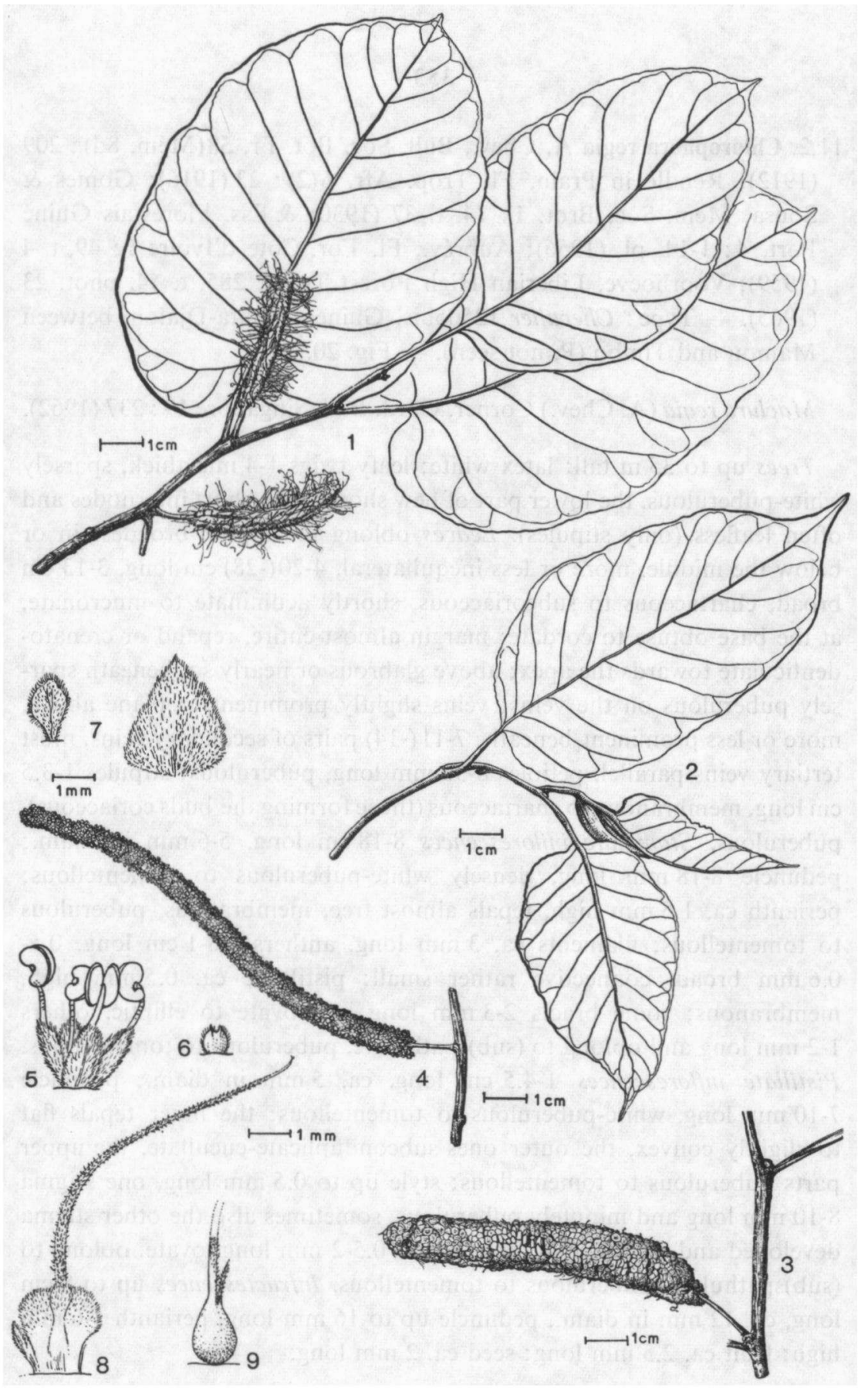

Fig. 20. - Chlorophora regia: 1 , leafy twig with pistillate inflorescences; 2 , leafy twig with long stipules; 3 , infructescence; 4 , staminate inflorescence; 5 , staminate flower; 6 , pistillode; 7, bracts of the staminate inflorescence; 8 , pistillate flower and bract; 9, ovary $(1,8,9$ : Leeuwenberg $2471 ; 2$ : Raimbault s.n.; 3 : de Wilde 1044; 4 : Voorhoeve 947; 5-7: Voorhoeve 180). 
hirtellous to hispidulous, usually scabrous, beneath appressed-puberulous on the main veins; the stipules chartaceous, puberulous.

Distribution (fig. 15, map 1) : From Gambia to western Ghana, in rain forests, or especially in the north-western part of the area in gallery forests; common or rare, at lower altitudes. Like Chlorophora excelsa, this species can often be found as a lone tree in cultivated areas (cf. Aubréville 1959; Voorhoeve 1965). According to Voorhoeve C. regia is deciduous for a short period in the dry season; according to White (1966) C. regia is more water-demanding and less drought-resistant than $C$. excelsa.

Number of collections : ca. 55.

Flowering from January to March, later in Guinea and Senegal (to June).

Most of what is said about the use of $C$. excelsa in the Useful Plants of West Tropical Africa, Hutchinson \& Dalziel (1937) also applies to C. regia (see also Voorhoeve 1965).

The (fallen) sweet infructescences attract game (coll. Cooper 332).

In the two available collections with infructescences only a small number of the pistils had developed into fruits.

12. Broussonetia L'Hérit. ex Vent., Tabl. Règne 3: 547 (1799), nom. conserv. - Type species : B. papyrifera (L.) Vent.

Dioecious trees; shoot apices shed. Leaves distichous, pinnately veined; stipules free, semi-amplexicaul. Inflorescences usually solitary in the leaf axils or on leafless nodes at the base of fertile twigs, pedunculate, bracteate; bracts basally attached; staminate inflorescences spicate, sometimes subcapitate, with a rather distinct abaxial sterile groove; flowers many; perianth 4-parted, segments valvate; stamens 4, inflexed, at anthesis bending outwards elastically, anthers introrse to latrorse; pistillode, if present, small, subulate; pistillate inflorescences capitate, sometimes elongated; flowers many; perianth unequally 2-4-lobed to 2-4-dentate; ovary free; stigmas 2 , one of them strongly reduced; the upper parts of the bracts cohering by entangling hairs. In fruit perianth 
enlarged but still membranous; fruit usually short-stipitate and slightly compressed, exocarp fleshy, for the greater part rather thinly so, thicker at the base and on the seed-bearing side; endocarp crustaceous, with a thickenend crest-like part at the apex and a small woody plug towards the hilum; testa thin, with a slightly thickened oblong vascularized part below the small hilum; endosperm present; embryo curved, cotyledons unequal or almost equal, subconduplicate to almost plane, straight or the apex reflexed, not enclosing the long radicle, if unequal the larger cotyledon more or less clasping the smaller one; the bracts more or less fused at the base and hardened at the apex.

Broussonetia greveana was illustrated in the atlas of Grandidier's History of Madagascar (Baillon 1895) under the name Ampalis greveana. Léandri (1948b) transferred the species to Chlorophora and described C. humbertii as a close relative. Chlorophora was reduced to a section of the broad genus Maclura by Corner (1962), who made the combinations $M$. greveana and $M$. humbertii. Capuron $(1968,1972)$ united the two Madagascan species, transferred them to Allaeanthus, and placed them near A. zeylanicus. Capuron's decision was also based on anatomical studies of the wood. In 1962 Corner had reduced Allaeanthus to a section of the genus Broussonetia, but Capuron preferred to regard Allaeanthus as distinct. If Corner's concept is adopted, the Madagascan species should be placed in Broussonetia. The above description completely matches the genus description of Broussonetia given by Corner. By and large it also agrees with the present description of Chlorophora. The main differences are in the perianth of the pistillate flower and in the infructescence (see also p. 333).

B. greveana shows abortion and shedding of shoot apices, like Morus mesozygia.

12.1. Broussonetia greveana (Baillon) C.C. Berg comb. nov. - Type : Grevé 254, Madagascar, Bekopaka, near Morondava (P). - Fig. 21.

Ampalis greveana Baillon in Grandidier, Hist. Madag., Bot., Atlas 3 : t. 293A (1895).

Chlorophora greveana (Baillon) Léandri, Mém. Inst. Sci. Madag., ser. B, 1 : 18, with plates (1948); H. Perrier \& Leandri in Humbert, Fl. Madag. Moraceae: 12, t. 3 (1952).

Maclura greveana (Baillon) Corner, Gard. Bull. Singapore 19: 237 (1962). 


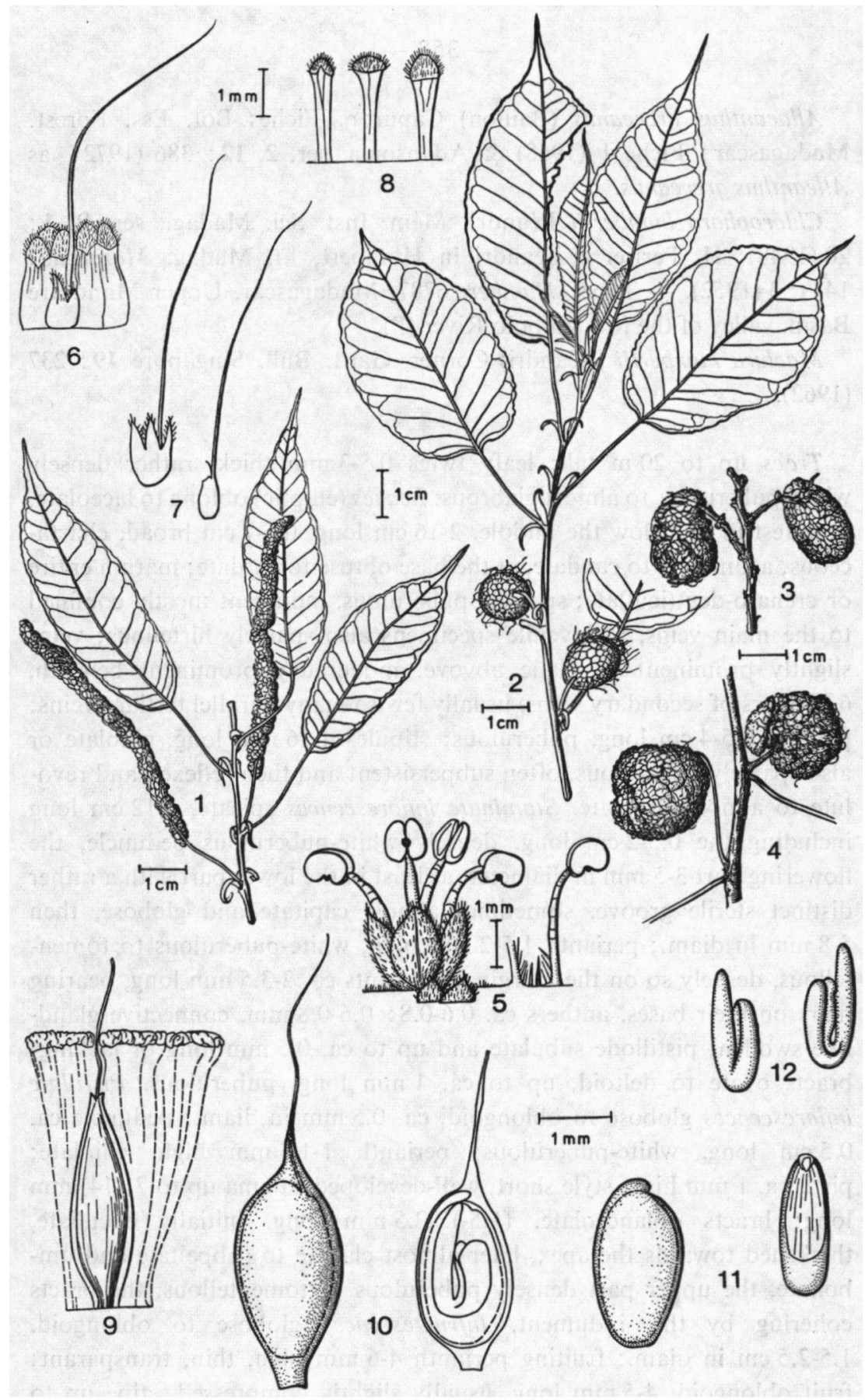

Fig. 21. - Broussonetia greveana: 1, leafy twigs with staminate inflorescences; 2, leafy twig with pistillate inflorescences; $3 \& 4$, twigs with infructescences; 5 , staminate fower, bracts and pistillode; 6 , pistillate flower and bracts; 7 , pistillate flower and pistil; 8 , bracts of pistillate flower; 9 , part of the infructescence; 10 , fruit; 11 , seed; 12 , embryo (1: Sero. For. Madag. 3956; 2, 6-8: Serv. For. Madag. 8373; 3 : Humbert 6787; 4, 9-12 : Capuron 6843; 5 : Sero. For. Madag. 15097). 
Allaeanthus greveanus (Baillon) Capuron, Fiches Bot. Ess. Forest. Madagascar: Fiche 1 (1968) \& Adansonia, ser. 2, 12: 386' (1972), as Alleanthus greveanus.

Chlorophora humbertii Léandri, Mém. Inst. Sci. Madag., ser. B, 1 : 20 (1948); H. Perrier \& Léandri in Humbert, Fl. Madag. Moraceae : 14, t. 3 (1952). - Type : Humbert 6787, Madagascar, Upper Mandrare Basin, valley of the Manambolo River (P).

Maclura humbertii (Léandri) Corner, Gard. Bull. Singapore 19: 237 (1962).

Trees up to $20 \mathrm{~m}$ tall; leafy twigs $0.5-3 \mathrm{~mm}$ thick, rather densely white-puberulous to almost glabrous. Leaves (elliptic) oblong to laceolate, broadest in or below the middle, $2-16 \mathrm{~cm}$ long, $0.5-7 \mathrm{~cm}$ broad, chartaceous, acuminate to caudate, at the base obtuse to cordate; margin entire or crenato-dent(icul)ate; sparsely puberulous, indument mostly confined to the main veins, in juvenile specimens also sparsely hirtellous; veins slightly prominent to plane abvove, moderately prominent beneath, 6-20 pairs of secondary veins, usually few to many parallel tertiary veins; petioles $0.5-4 \mathrm{~cm}$ long, puberulous; stipules $4-16 \mathrm{~mm}$ long, ciliolate or also sparsely puberulous, often subpersistent and then reflexed and revolute to almost circinate. Staminate inflorescences spicate, $1-12 \mathrm{~cm}$ long including the $0.5-2 \mathrm{~cm}$ long, densely white-puberulous peduncle, the flowering part 3-5 $\mathrm{mm}$ in diameter, at least in the lower part with a rather distinct sterile groove, sometimes almost capitate and globose, then $5-8 \mathrm{~mm}$ in diam.; perianth $1.5-2 \mathrm{~mm}$ high, white-puberulous to tomentellous, densely so on the margins; filaments ca. $2-3.5 \mathrm{~mm}$ long, bearing hairs on their bases, anthers ca. $0.6-0.8 \times 0.6-0.8 \mathrm{~mm}$, connective glandlike swollen; pistillode subulate and up to ca. $0.5 \mathrm{~mm}$ long or lacking; bracts ovate to deltoid, up to ca. $1 \mathrm{~mm}$ long, puberulous. Pistillate inflorescences globose to oblongoid, ca. $0.5 \mathrm{~mm}$ in diam.; peduncle ca. $0.5 \mathrm{~cm}$ long, white-puberulous; perianth $1-1.5 \mathrm{~mm}$ high, ciliolate; pistil ca. $1 \mathrm{~mm}$ high, style short, well-developed, stigma up to $7(-14) \mathrm{mm}$ long; bracts oblanceolate, (1.5-)2-2.5 mm long, initially cucullate, thickened towards the apex, later almost clavate to subpeltate and umbonate, the upper part densely puberulous to tomentellous, the bracts cohering by this indument. Infructescences globose to oblongoid, $1.5-2.5 \mathrm{~cm}$ in diam.; fruiting perianth $4-6 \mathrm{~mm}$ high, thin, transparant; fruit oblongoid, $4-5 \mathrm{~mm}$ long, usually slightly compressed, stipe up to ca. $1 \mathrm{~mm}$ long; seed ca. $3 \mathrm{~mm}$ long, cotyledons up to ca. $2 \mathrm{~mm}$ long, radicle ca. $2.5 \mathrm{~mm}$ long; in fruit bracts up to $5.8 \mathrm{~mm}$ long, more or less 
flattened, the upper parts somewhat hardened, most bracts basally more or less connate.

Distribution (fig. 15, map 1): Madagascar, mainly in the western part of the island, also in the Comoro Islands (Mayotte), as deciduous or sometimes evergreen trees or shrubs, mostly in dry forests or thickets on limestone or sand, especially in the southern part of the area often along streams (cf. Capuron 1968); from sealevel to $800 \mathrm{~m}$ altitude.

Number of collections examined : ca. 45.

Flowering from (June) September to December, fruiting from November to January. As a rule the trees flower when coming into new foliage.

13. Cardiogyne Bur. in DC., Prodr. 17 : 232 (1873); Baillon, Hist. Pl. 6 : 194 (1875-1876); Benth. \& Hook., Gen. Pl. 3(1): 362 (1880); Engl. in Engl. \& Prantl, Nat. Pflanzenfam. 3(1): 76(1889); A. Richter, Term. Füzetek 18: 294 (1895); Kaastra, Acta Bot. Neerl. 22 : 69 (1973). - Type species: C. africana Bur.

Maclura Nutt. sect. Cardiogyne (Bur.) Corner, Gard. Bull. Singapore 19: 237 (1962).

Dioecious shrubs, trees, or climbers, armed with short branches ending in a spine. Leaves in spirals, often tending to be distichous, pinnately veined; stipules free and lateral (or connate) on short-shoots. Inflorescences solitary or in pairs in the axils of the leaves, capitate, pedunculate, with basally attached bracts often containing immersed yellow glands; flowers numerous; perianth 4-lobed or 4-parted, segments decussateimbricate, often with immersed yellow glands; stamens 4, inflexed, at anthesis bending outward elastically, anthers introrse to latrorse; pistillode rather small, flat; ovary free, stigma 1, occasionally 2, apical. In fruit perianths enlarged, fleshy and yellow to orange, sometimes basally connate; fruit free; endocarp crustaceous with a small woody plug towards the hilum; testa thin, with an orbicular to oblong thickened vascularized part below the hilum or forming an apical cap; cotyledons nearly equal, flat, strongly plicate, enclosing the long radicle.

The first account of $C$. africana was given by Kirk (1867), who recognized it as a species of Cudrania, partly by the yellow dye yielded by the wood. Bureau (1873) regarded Cardiogyne as closely related to Plecosper- 
mum and as the moraceous analogue of the artocarpaceous genus Cudrania. Bentham \& Hooker (1880) placed Cardiogyne under Plecospermum, without making a new combination. Remarks of both authors show that they saw distinct relationships between Chlorophora, Maclura, Bagassa, Broussonetia, Allaeanthus, Cudrania, Plecospermum, and Cardiogyne. Since the treatment of the Moraceae by Engler (1889) the genera mentioned have been regarded as distinct, until Corner (1962) united Allaeanthus with Broussonetia, and Chlorophora, Cudrania and Cardiogyne with Maclura.

As stated above (p. 348), Corner's decision with regard to Maclura is not very satisfactory. The relationships of Cardiogyne with Plecospermum and Cudrania have been the subject of a study by Richter (1895), which, however, did not lead to conclusions. By comparing members of Maclura sensu Corner, Kaastra (1973) concluded that C. africana can be regarded as congeneric with the American $M$. pomifera and $M$. brasiliensis. Further study of Maclura s.l. in which the genus Plecospermum has to be involved may prove that Kaastra's conclusion is right (see also p. 331).

The species was described as Milicia spinosa by Sim (1909), but was soon recognized as identical with $C$. africana (cf. Rendle 1916).

13.1. Cardiogyne africana Bur. in DC., Prodr. 17: 233 (1873); Kirk, Journ. Linn. Soc. 9 : 229 (1867); Oliver in Hook., Icon. Pl. : t. 2473 (1896); Baillon in Grandidier, Hist. Madag., Bot., Atlas 3: t. 294 (1895); Engl., Monogr. Afr. Pfl. 1(Moraceae): 4 (1898); Rendle in Prain, Fl. Trop. Afr. 6(2) : 24 (1916). — Type : Boivin s.n. \$, Tanzania, Zanzibar (P; isotype B). - Fig. 22.

Maclura africana (Bur.) Corner, Gard. Bull. Singapore 19: 237 (1962).

Milicia spinosa Sim, For. Fl. Port. E. Afr. : 98, t. 74B (1909). — Type : Sim 6163, Moçambique (not yet traced).

Shrubs or treelets up to $7 \mathrm{~m}$ tall, with many long, straggling, climbing, arching, or drooping branches, these usually with up to $10 \mathrm{~cm}$ long, straight or slightly curved branchlets ending in a spine; leafy twigs 1-4 mm thick, white to brownish puberulous to short-velutinous. Leaves elliptic to lanceolate, sometimes suborbicular, $1.5-9 \mathrm{~cm}$ long, $1-4.5 \mathrm{~cm}$ broad, not or slightly inequilateral, subcoriaceous, obtuse, subacute, short- 


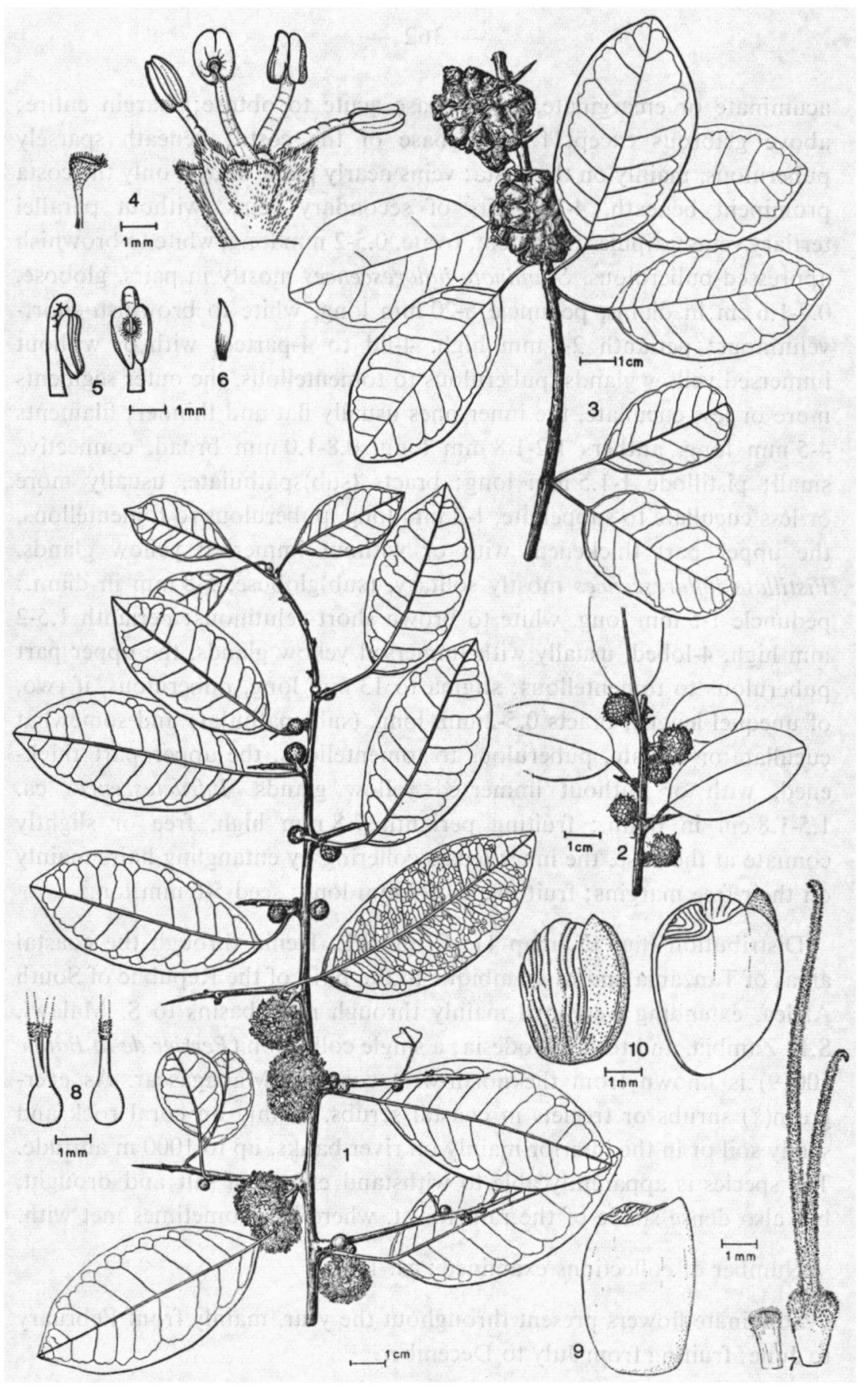

Fig. 22. - Cardiogyne africana: 1, leafy twig with staminate inflorescences; 2, leafy twig with pistillate inflorescences; 3, leafy twig with infructescences; 4 , staminate flower and bracts; 5, stamens; 6, pistillode; 7, pistillate flower and bract; 8, pistil; 9, seed; 10, embryo (1: Torre 7142; 2: Andrada 1644; 3, 9, 10: Simão 603; 4-6: Faulkner 1610; 7, 8: Drummond \& Hemsley 2391). 
acuminate or emarginate, at the base acute to obtuse; margin entire; above glabrous except for the base of the costa; beneath sparsely puberulous, mainly on the costa; veins nearly plane above, only the costa prominent beneath, 4-12 pairs of secondary veins, without parallel tertiary veins; stipules persistent, ovate, $0.5-2 \mathrm{~mm}$ long, white to brownish appressed-puberulous. Staminate inflorescences mostly in pairs, globose, $0.7-1.6 \mathrm{~cm}$ in diam.; peduncle $5-20 \mathrm{~mm}$ long, white to brownish shortvelutinous; perianth 2-3 $\mathrm{mm}$ high, 4-fid to 4-parted, with or without immersed yellow glands, puberulous to tomentellous, the outer segments more or less cucullate, the inner ones usually flat and thinner; filaments 4-5 mm long, anthers $1.2-1.8 \mathrm{~mm}$ long, $0.8-1.0 \mathrm{~mm}$ broad, connective small; pistillode 1-1.5 mm long; bracts (sub)spathulate, usually more or less cucullate to subpeltate, $1-2 \mathrm{~mm}$ long, puberulous to tomentellous, the upper part thickened, with or without immersed yellow glands. Pistillate inflorescences mostly solitary, (sub)globose, 5-8 mm in diam.; peduncle $1-5 \mathrm{~mm}$ long, white to brown short-velutinous; perianth 1.5-2 $\mathrm{mm}$ high, 4-lobed, usually with immersed yellow glands, the upper part puberulous to tomentellous; stigma to $13 \mathrm{~mm}$ long, puberulous, if two, of unequel length; bracts $0.5-2 \mathrm{~mm}$ long, (sub)spathulate and somewhat cucullate or clavate, puberulous to tomentellous, the upper part thickened, with or without immersed yellow glands. Infructescences ca. $1.5-1.8 \mathrm{~cm}$ in diam.; fruiting perianth $7-8 \mathrm{~mm}$ high, free or slightly connate at the base, the inner tepals cohering by entangling hairs mainly on their free margins; fruit ovate, 6-7 mm long; seed 5-6 mm long.

Distribution (fig. 15, map 1): From S.E. Kenia through the coastal areas of Tanzania and Moçambique to the N.E. of the Republic of South Africa, extending westward mainly through river basins to $\mathrm{S}$. Malawi, S.E. Zambia, and to E. Rhodesia; a single collection (Perrier de la Bâthie 10019) is known from the north-west coast of Madagascar. As evergreen(?) shrubs or treelets in coastal scrubs, mainly on coral rock and sandy soil or in the interior mainly on river banks, up to $1000 \mathrm{~m}$ altitude. The species is apparently able to withstand effects of salt and drought, but also dense shade of the rain forest, where it is sometimes met with.

Number of collections examined : ca. 120.

Staminate flowers present throughout the year, mainly from February to June; fruiting from July to December.

The yellow to orange infructescences with tasty pulp are edible. They are eaten by birds. 
A remarkable feature of $C$. africana is the presence of short branchlets ending in a spine. They assist in climbing and straggling. On short branchlets or on the end of longer ones the nodes only bear (fused) stipules. These branchlets may bear inflorescences and/or side-branchlets also ending in a spine.

The immersed yellow glands occur below the thickened part of tepals and bracts. Normally two glands occur, each beside the midvein, but they are not regular in their occurrence. In some specimens they are lacking or strongly reduced. In pistillate flowers they may be absent at anthesis but then develop during maturing of the fruit.

The margins of the opposite segments of the perianth of the pistillate flower cohere by entangling hairs. This always happens with the inner tepals, with the outer tepals only if their margins approach each other. This phenomenon is especially distinct in fruiting perianths.

14. Sloetiopsis Engl., Bot. Jahrb. 39 : 573 (1907); Engl., Bot. Jahrb. 51 : 426 (1914); Corner, Gard. Bull. Singapore 19 : 211, 227 (1962). - Type species : S. usambarensis Engl.

Neosloetiopsis Engl., Bot. Jahrb. 51 : 426 (1914): Rendle in Prain, Fl. Trop. Afr. 6(2) : 78 (1916); Hauman, Fl. Congo, Ruanda-Urundi 1 : 82 (1948); Corner, Gard. Bull. Singapore 19: 211, 227 (1962). — Type species: N. kamerunensis Engl. (= Sloetiopsis usambarensis Engl.).

Dioecious (or monoecious) shrubs or small trees. Leaves distichous, pinnately veined, stipules free, semi-amplexicaul. Inflorescences solitary in the axils of the leaves, (normally) unisexual, staminate ones spicate, with an abaxial sterile groove, bracteate (partly with peltate bracts); perianth 4-fid, segments imbricate; stamens 4 , inflexed before anthesis, bending outward elastically at anthesis, anthers introrse; pistillode very small; pistillate inflorescences uniflorous, bracteate; perianth with 4 free, imbricate tepals; ovary free; stigmas 2 , filiform. In fruit perianth enlarged, greenish, hardly fleshy; exocarp thick, white, fleshy, and dehiscent, pushing the endocarp body upwards; endocarp coriaceous, with a hard disc against the hilum; testa vascularized, with a thickened, more closely vascularized apical cap; cotyledons equal, thick, radicle apical and very short.

The description of the genus Sloetiopsis and the species $S$. usambarensis by Engler (1907) was based on a collection with for the species abnormal 
spicate inflorescences with both staminate and pistillate flowers. Because of the resemblance in the inflorescence, Sloetiopsis was associated with the Asian genus Sloetia. Neosloetiopsis with $N$. kamerunensis, also described by Engler (1914), was based on material with for the species normal one-flowered pistillate inflorescences.

Up to present the two genera, both still monotypic, were treated as distinct, although in 1948 Léonard only just failed to place Neosloetiopsis in the synonymy of Sloetiopsis.

Corner (1962) connected both Sloetiopsis and Neosloetiopsis with the broad genus Streblus, especially with sect. Sloetia. As stated before (p. 330), Sloetiopsis and Sloetia may prove to be congeneric and may be regarded as related to Bleekrodea.

14.1. Sloetiopsis usambarensis Engl., Bot. Jahrb. 39: 573, pl. (1907); Engl., Pflanzenw. Afr. 3(1): 20, t. 10 (1915). - Type : Engler 3263, Tanzania, Usambara, Mombo (B). - Fig. 23.

Neosloetiopsis kamerunensis Engl., Bot. Jahrb. 51 : 426, t. 1 (1914). Type: Mildbraed 4331, Cameroun, N. of Moloundou (B).

Dioecious or sometimes monoecious shrubs or trees up to $10 \mathrm{~m}$ tall; latex white or yellowish; leafy twigs $1-2 \mathrm{~mm}$ thick, sparsely to densely puberulous, some or all hairs uncinate, often the hairs distinctly different in length. Leaves (elliptic to) oblong (to lanceolate), usually broadest in the middle, especially towards the base inequilateral, $(1-) 3-16(-23) \mathrm{cm}$ long, (0.5)1.5-6(-10) $\mathrm{cm}$ broad, chartaceous to subcoriaceous, acuminate to caudate, sometimes subacute, at the base obtuse to acute; margin entire or faintly to coarsely dentate towards the apex; on both surfaces (sub)glabrous; veins slightly prominent to plane above, prominent beneath, 4-13 pairs of secondary veins, no parallel tertiary veins; petioles 2-7 $\mathrm{mm}$ long, mostly puberulous (with uncinate hairs); stipules $2-8 \mathrm{~mm}$ long, usually with more or less distinct parallel prominent veins, sparsely puberulous, often subpersistent. Staminate inflorescences $0.5-5 \mathrm{~cm}$ long, at anthesis ca. $4 \mathrm{~mm}$ in diam., subsessile to pedunculate, peduncle up to $1.5 \mathrm{~mm}$ long; flowers not very close together; perianth ca. $1.5 \mathrm{~mm}$ high, 4(-6)-fid [to 4(-6)-parted], membranous, almost glabrous; filaments 2-2.5 mm long, anthers $0.6-0.8 \times 0.8-1.0 \mathrm{~mm}$, connective small; pistillode $0.1 \mathrm{~mm}$ high, conical; bracts basally attached or mostly (sub)peltate and suborbicular, up to ca. $1 \mathrm{~mm}$ in diameter, puberulous and ciliolate. Pistillate inflorescences: peduncle (including the rachis) $2-3 \mathrm{~mm}$ long, 


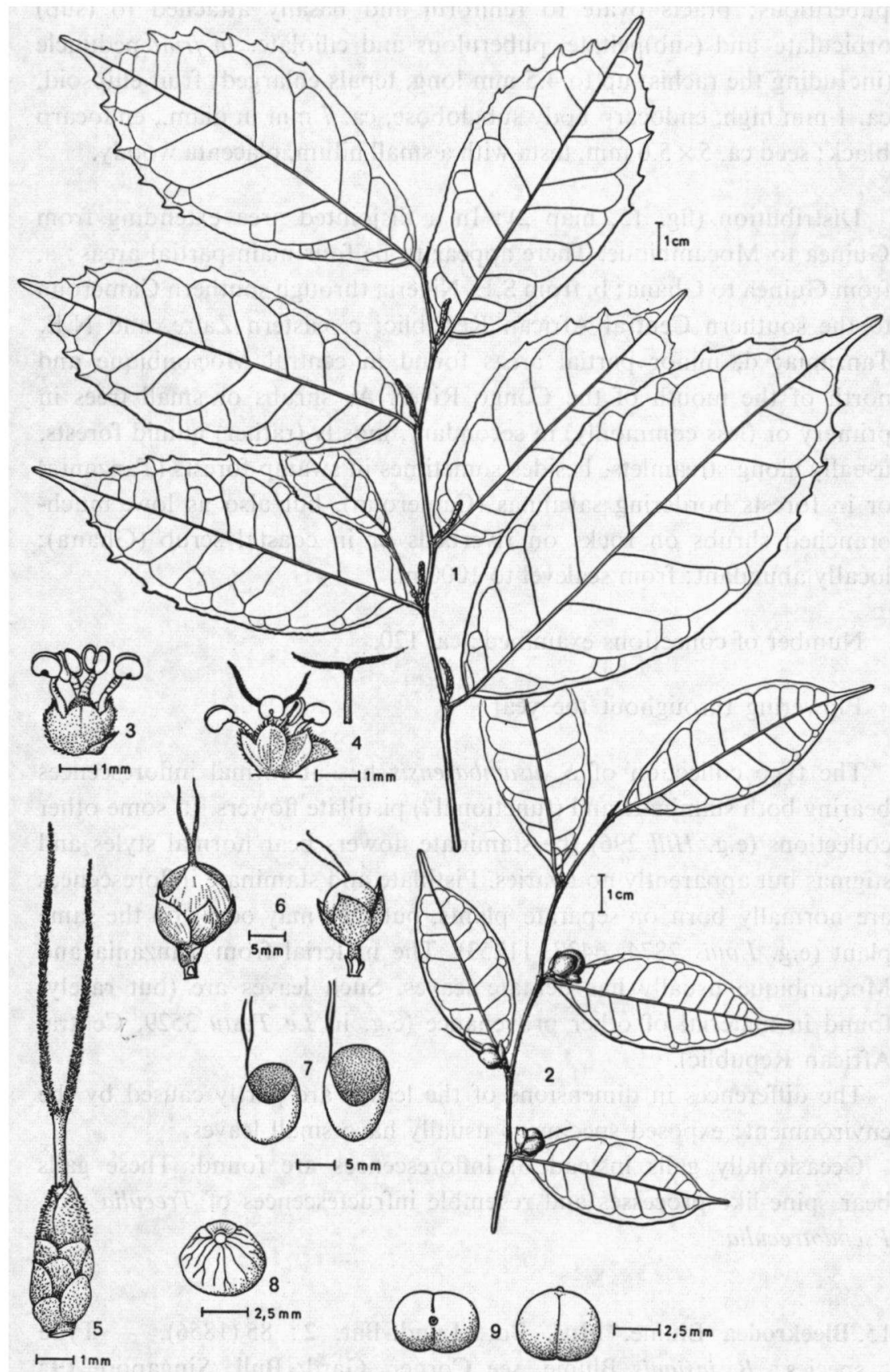

Fig. 23. - Sloetiopsis usambarensis : 1, leafy twig with young staminate inflorescences; 2 , leafy twig with young infructescences; 3 , staminate flower and bract; 4 , staminate flower with bract and pistillode; 5 , pistillate inflorescence; 6 , infructescence; 7 , fruit; 8, seed; 9, embryo (1: Simøo 336; 2: Gutzwiller 2514; 3 : de Wilde 3542; 4 : Hill 296; 5 : Breteler 1865; 6-9: Breteler 1507). 
puberulous; bracts ovate to reniform and basally attached to (sub) orbiculate and (sub)peltate, puberulous and ciliolate. In fruit peduncle (including the rachis) up to $4.5 \mathrm{~mm}$ long, tepals enlarged; fruit ellipsoid, ca. $1 \mathrm{~mm}$ high, endocarp body subglobose, ca. $7 \mathrm{~mm}$ in diam., endocarp black; seed ca. $5 \times 5.6 \mathrm{~mm}$, testa with a small hilum, placenta woody.

Distribution (fig. 15, map 2): In a disjointed area extending from Guinea to Moçambique. There appear to be four main partial areas : a, from Guinea to Ghana; $b$, from S.E. Nigeria through southern Cameroun to the southern Central African Republic; c, eastern Zaire, and N.E. Tanzania; d, minor partial areas found in central Moçambique and north of the mouth of the Congo River. As shrubs or small trees in primary or (less commonly) in secondary, mostly (rather) humid forests, usually along streamlets, besides sometimes in swamp forests (Tanzania) or in forests bordering savannas (Cameroun), but also as low, muchbranched shrubs on rocks on riverbeds or in coastal scrub (Ghana); locally abundant; from sealevel to $1000 \mathrm{~m}$.

Number of collections examined : ca. 120.

Flowering throughout the year.

The type collection of $S$. usambarensis has abnormal inflorescences bearing both staminate and (functional?) pistillate flowers. In some other collections (e.g. Hill 296) the staminate flowers bear normal styles and stigmas but apparently no ovaries. Pistillate and staminate inflorescences are normally born on separate plants, but they may occur on the same plant (e.g. Louis 2874, 6437, 11253). The material from Tanzania and Moçambique usually has dentate leaves. Such leaves are (but rarely) found in material of other provenance (e.g. in Le Testu 3529, Central African Republic).

The differences in dimensions of the leaves are partly caused by the environment; exposed specimens usually have small leaves.

Occasionally galls instead of inflorescences are found. These galls bear spine-like processes and resemble infructescences of Treculia sect. Pseudotreculia.

15. Bleekrodea Blume, Mus. Bot. Lugd.-Bat. 2: 85 (1856). - Type species : B. insignis Blume, see Corner, Gard. Bull. Singapore 19: 216 (1962). 
Streblus Lour. sect. Bleekrodea (Blume) Corner, Gard. Bull. Singapore 19 : 216 (1962).

Monoecious shrubs. Leaves distichous, pinnately veined; stipules free, semi-amplexicaul. Inflorescences solitary in the leaf axils, short-branchedcymose or subcapitate, bisexual or sometimes staminate or pistillate, pedunculate, bracteate, sometimes subinvolucrate; staminate flowers one to several, sessile or short-pedicellate; perianth 5-fid to 5-parted, segments valvate; stamens 5 , inflexed, at anthesis bending outward elastically, anthers introrse; pistillode small, conical; pistillate flowers 1-2 in the centre of the inflorescence; perianth tubular, 4-dentate; ovary free; stigmas 2, of equal length. In fruit perianth enlarged; exocarp thick, white, fleshy, and dehiscent. pushing the endocarp body upwards through the perianth; testa with a slightly thickened vascularized part below the rather small hilum; cotyledons very unequal, the smaller one in a cavity of the thick, larger cotyledon, hidden by the slightly curved, short radicle.

In 1856 Blume described Bleekrodea with two species, $B$. madagascariensis and B. insignis (from Borneo). Corner (1962) who reduced the genus to a section of the broad genus Streblus, described a third species, Streblus (Bleekrodea) malayensis from Malaya in 1975. The three species are very closely related. Bleekrodea and Fatoua show similarities in their disjunct distribution. Although Bleekrodea appears to be related to some members of Streblus s.l., it is justified to assign it the rank of genus, mainly because of the tubular perianth of the pistillate flower. The closest relatives of Bleekrodea appear to be Sloetiopsis (and Sloetia) and Fatoua. Furthermore, the inflorescences of Bleekrodea show resemblances to those of Utsetela and Helianthostylis, presently ranked among the Dorstenieae (see p. 269, 290).

15.1. Bleekrodea madagascariensis Blume, Mus. Bot. Lugd.-Bat. 2: 88 (1856); Baillon in Grandidier, Hist. Madag., Bot., Atlas 3: t. 295 (1895); Léandri, Mém. Inst. Sci. Madag., ser. B, 1 : 5, pl. (1948); H. Perrier \& Léandri in Humbert, Fl. Madag. Moraceae : 6, t. 1 (1952). Type : Pervillé 694, Madagascar, Nossi Bé (L; isotypes B, BM, E, G, K, P). - Fig. 24.

Streblus madagascariensis (Blume) Corner, Gard. Bull. Singapore 19: 220 (1962). 


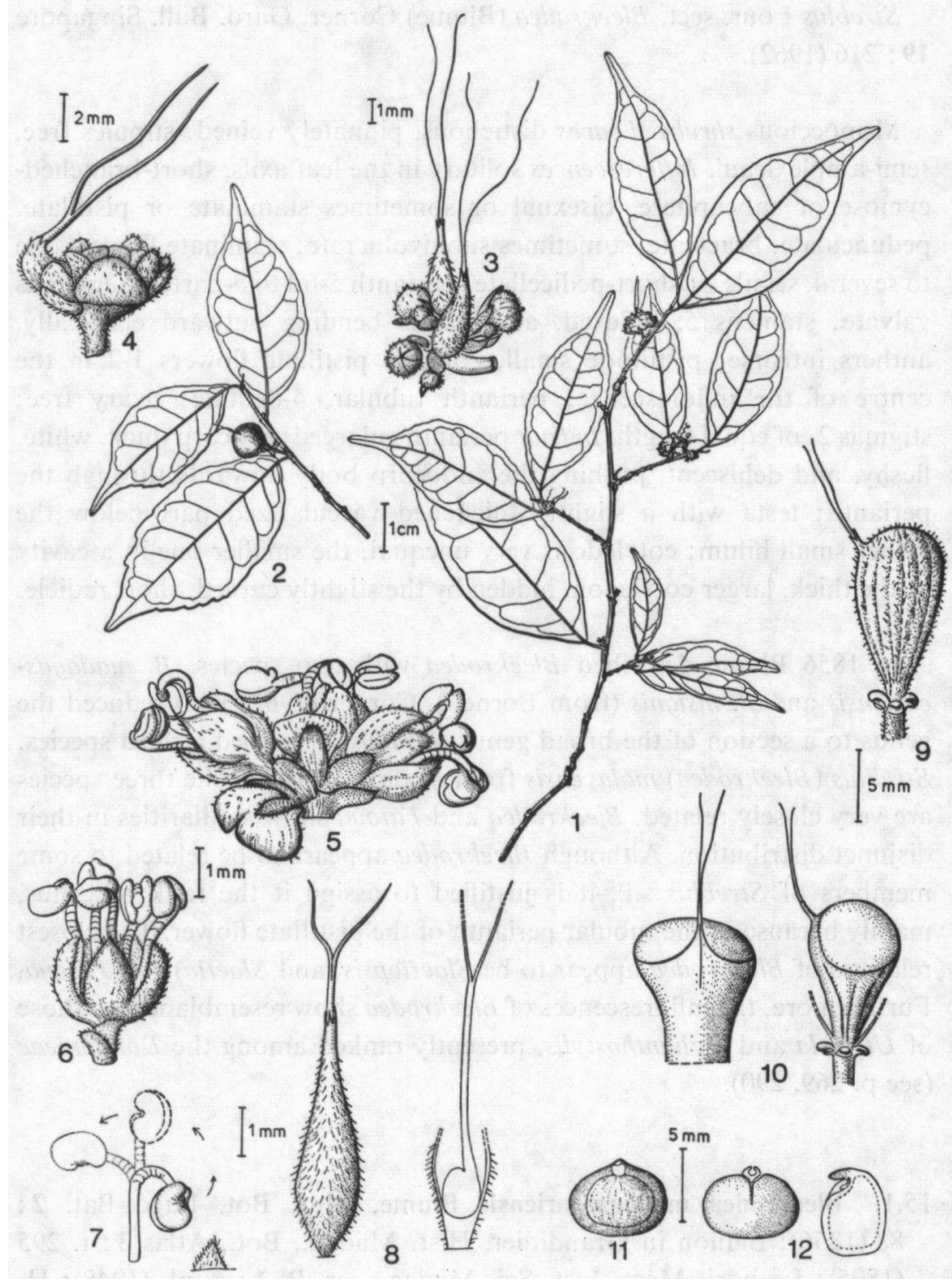

Fig. 24. - Bleekrodea madagascariensis: 1, leafy twig with inflorescences; 2, leafy twig with infructescence; $3 \& 4$, inflorescences; 5 , staminate inflorescence; 6 , staminate flower; 7 , stamen and pistillode; 8, pistillate flower and pistil; 9, infructescence; 10, fruit; 11, seed; 12, embryo (1: Razafindrakota 4688; 2 : Léandri \& Saboureau 2619; 3: Léandri 2817;4-7: Pervillé 694; 8: Léandri \& Saboureau 2817; 9-12: Capuron 23287). 
Bleekrodea madagascariensis var. longifolia Bur. in DC., Prodr. 17: 255 (1873). - Type : Boivin 2028, Madagascar, Nossi Bé, Djabal (P).

Shrubs or small trees up to $5 \mathrm{~m}$ tall. Leafy twigs $0.5-2 \mathrm{~mm}$ thick, (sparsely) puberulous, some or all hairs retrorse and uncinate. Leaves elliptic to oblong to lanceolate, broadest in or above the middle, $1-8(-12) \mathrm{cm}$ long, $0.5-3(-5.5) \mathrm{cm}$ broad, chartaceous to subcoriaceous, acuminate to (sub)caudate, at the base acute to obtuse; margin entire, subentire, denticulate to dentate, or irregulary pinnatilobed to -parted; above with sparse hairs, glabrescent, beneath sparsely puberulous with uncinate hairs on the veins; above veins almost plane, the costa often slightly impressed, beneath veins prominent, 3-9(-12) pairs of secondary veins, no parallel tertiary veins; petioles $1-5 \mathrm{~mm}$ long, puberulous with uncinate hairs; stipules subpersistent, $1-7 \mathrm{~mm}$ long, sparsely puberulous to almost glabrous, with a prominent costa. Inflorescences ca. 4-12 mm in diam., shortly pedunculate to subsessile; peduncle up to $7 \mathrm{~mm}$ long, bracteate, puberulous to subglabrous; staminate flowers sometimes wanting or one to several, sessile or shortly pedicellate, pedicel up to $2 \mathrm{~mm}$ long; perianth 1.5-2 mm high, sparsely puberulous; filaments $3-4 \mathrm{~mm}$ long, anthers ca. 0.8-1.0 $\times 0.8-1.0 \mathrm{~mm}$, connective rather small; pistillode ca. $0.5 \mathrm{~mm}$ long, hairy; perianth of the pistillate flower tubular, ca. 3-5 mm high, (2-)4dentate, puberulous with straight and uncinate hairs; ovary ca. $1 \mathrm{~mm}$ high, style $3.5-5 \mathrm{~mm}$ long, stigmas filiform, to $9 \mathrm{~mm}$ long; bracts basally attached, deltoid to ovate to linear, rather thick, sparsely puberulous. In fruit perianth ca. $1 \mathrm{~cm}$ high, oblongoid to obovoid to subglobose, slightly fleshy, pink, sparsely puberulous; fruit ca. $1 \mathrm{~cm}$ long, endocarp body ca. $5 \times 7 \mathrm{~mm}$, usually broader than long, endocarp rather thin; seed ca. $5 \times 6 \mathrm{~mm}$, testa thin; the smaller cotyledon ligulate.

Distribution (fig. 15, map 2): North-western Madagascar, as evergreen or deciduous shrubs in the undergrowth of humid to dry forests or thickets, often (?) along streams, on various soils, from sealevel to $600 \mathrm{~m}$.

Number of collections examined : ca. 40.

Flowering throughout the year.

Like Fatoua madagascariensis, this species may bear unisexual inflorescences, either pistillate or staminate. As far as could be deduced from the herbarium material, the endocarp body, pushed upwards by the exocarp, is exposed and/or released through a tear in the fruiting perianth. The 
pinkish colour of the fruiting perianth (noted by Léandri \& Saboureau 2886) may play a part in dispersal. If so, B. madagascariensis is better adapted to dispersal than, e.g., Sloetiopsis usambarensis with its green fruiting perianth (see p. 363).

16. Fatoua Gaudich. in Freyc., Voy. Monde Bot. : 509 (1830). - Type species: $F$. pilosa Gaudich.

Plants monoecious, suffrutescent to herbaceous; latex absent. Leaves distichous, pinnately veined; stipules free, lateral. Inflorescences in pairs in the axils of the leaves, spicate, bisexual, sometimes staminate or pistillate, bracteate, pedunculate, abaxially without flowers; flowers sessile or short-pedicellate; perianth 4-parted, segments valvate; stamens 4, inflexed, at anthesis bending outward elastically, anthers introrse; pistillode minute; ovary free, style lateral, one of the stigmas strongly reduced. In fruit perianth enlarged, exocarp thick, white fleshy and dehiscent (probably) ejecting the endocarp body; testa thin with a slightly thickened suborbicular vascularized part near the small hilum, endosperm present; embryo curved, cotyledons equal and plane, radicle long.

The genus Fatoua was established by Gaudichaud (1830) when describing the new species $F$. pilosa. This species, extending from Japan to New Caledonia, was the only Fatoua species recognized for a long time. The second species was not collected until 1933 by Humbert (coll. 11242) and described by Léandri (1948b).

$F$. madagascariensis is distinctly related to $F$. pilosa. A remarkable difference between the two species is found in the inflorescence which is spicate to racemose in the former and cymose in the latter. The inflorescence of $F$. pilosa resembles that of Bleekrodea. Fatoua is a clear-cut genus, probably related to Bleekrodea, and through this genus linked with Sloetiopsis (and Sloetia) (see p. 330).

Latex seems to be absent in $F$. madagascariensis. Léandri (1948b) did not even find laticiferous elements when studying the anatomy of this species.

16.1. Fatoua madagascariensis Léandri, Mém. Inst. Sci. Madag., ser. B, 1 : 4, pl. (1948); H. Perrier \& Léandri in Humbert, Fl. Madag. Moraceae : 4, t. 1 (1952); Bosser \& Léandri, Le Naturaliste Malgache 19: 37, pl. (1957). - Type: Humbert 11242, Madagascar, forest of Besomaty, between the Fiherenana and Isuhaina Rivers (P). - Fig. 25. 


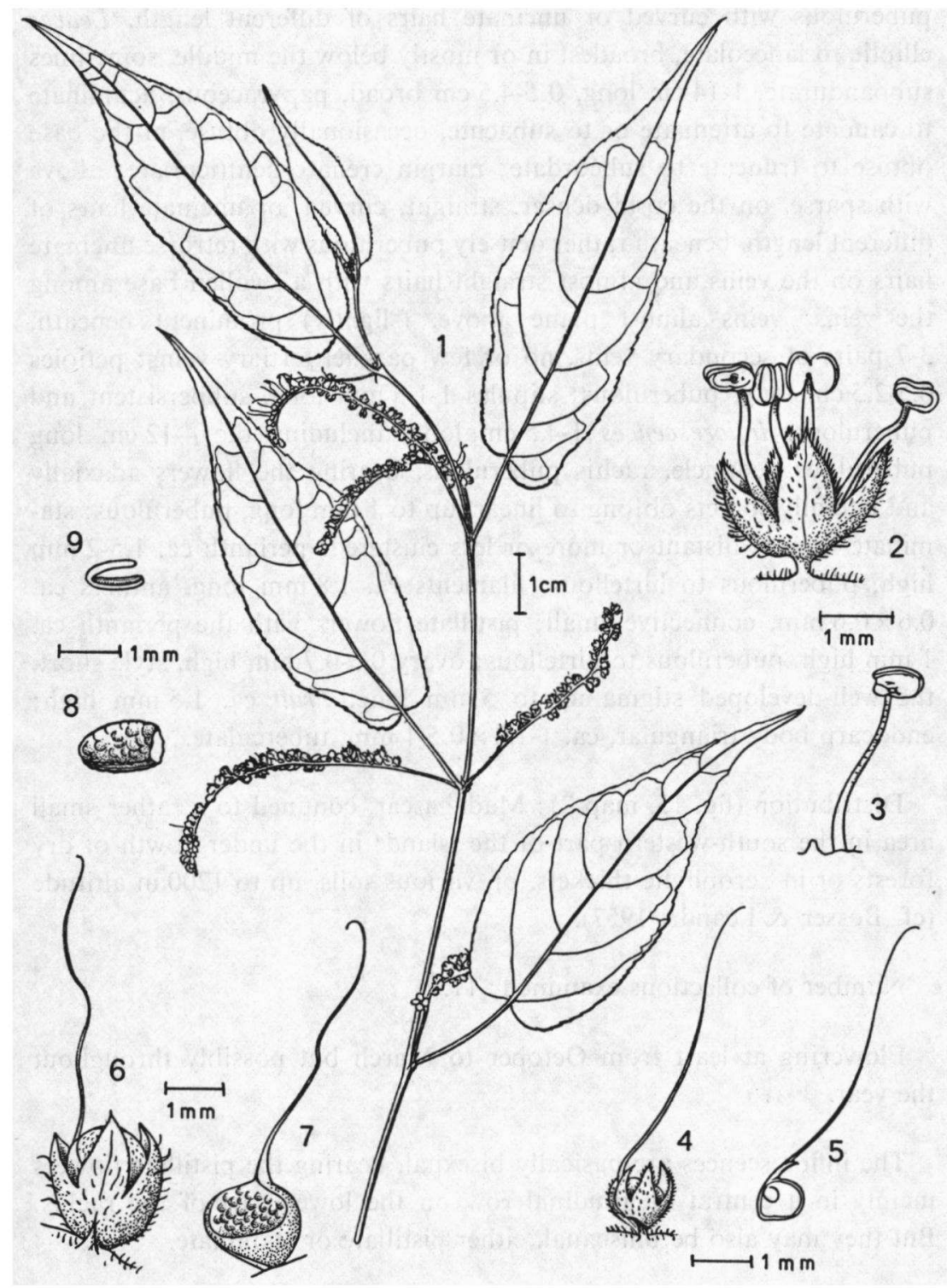

Fig. 25. - Fatoua madagascariensis: 1, leafy twig with inflorescences; 2 , staminate flower; 3, stamen and pistillode; 4, pistillate flower; 5 , pistil; 6, pistillate flower in fruit; 7, fruit; 8, seed; 9, embryo (Capuron 20602). 
Plants up to $1 \mathrm{~m}$ tall; roots yellow; leafy twigs $0.5-1.5 \mathrm{~mm}$ thick, puberulous with curved or uncinate hairs of different length. Leaves elliptic to lanceolate, broadest in or mostly below the middle, sometimes subpandurate, $1-14 \mathrm{~cm}$ long, $0.5-4.5 \mathrm{~cm}$ broad, papyraceous, acuminate to caudate to attenuate or to subacute, occasionally obtuse, at the base obtuse to truncate to subcordate; margin crenato-dent(icul)ate; above with sparse, on the costa denser, straight, curved, or uncinate hairs of different length, beneath rather densely puberulous with retrorse uncinate hairs on the veins and almost straight hairs with a swollen base among the veins; veins almost plane above, (slightly) prominent beneath, 3-7 pairs of secondary veins, no or few parallel tertiary veins; petioles 0.5-2.5 cm long, puberulous; stipules $1-1.5 \mathrm{~mm}$ long, subpersistent and puberulous. Inflorescences $1-4.5 \mathrm{~cm}$ long, including the $4-12 \mathrm{~cm}$ long puberulous peduncle, rachis puberulous, bearing the flowers adaxially and laterally; bracts oblong to linear, up to $1 \mathrm{~mm}$ long, puberulous; staminate flowers distant or more or less clustered; perianth ca. $1.5-2 \mathrm{~mm}$ high, puberulous to hirtellous; filaments ca. $1.8 \mathrm{~mm}$ long, anthers ca. $0.6 \times 0.6 \mathrm{~mm}$, connective small; pistillate flowers with the perianth ca. $1 \mathrm{~mm}$ high, puberulous to hirtellous; ovary $0.5-0.7 \mathrm{~mm}$ high, style short, the well-developed stigma up to $5 \mathrm{~mm}$ long. Fruit ca. $1.5 \mathrm{~mm}$ high; endocarp body triangular, ca. $1-1.3 \times 0.5-1 \mathrm{~mm}$, tuberculate.

Distribution (fig. 15, map 2): Madagascar, confined to a rather small area in the south-western part of the island; in the undergrowth of dry forests or in xerophytic thickets, on various soils, up to $1200 \mathrm{~m}$ altitude (cf. Bosser \& Léandri 1957).

Number of collections examined : 11.

Flowering at least from October to March but possibly throughout the year.

The inflorescences are basically bisexual, bearing the pistillate flowers mainly in a central longitudinal row on the lower part of the rachis. But they may also be unisexual, either pistillate or staminate.

17. Maillardia Frapp. ex Duchartre in Maillard, Notes sur l'île de la Réunion, Annexe P. : 3 (1863?); Bur. in DC., Prodr. 17 : 220 (1873); Benth. \& Hook., Gen. Pl. 3(1): 360 (1880); Léandri, Mém. Inst. Sci. Madag., ser. B, 1 : 23 (1948); H. Perrier \& Léandri in Humbert, Fl, 
Madag. Moraceae : 15 (1952). - Type species: M. borbonica Duchartre.

Trophis P. Br. sect. Maillardia (Duchartre) Corner, Gard. Bull Singapore 19 : 230 (1962).

Dioecious trees. Leaves distichous, pinnately veined; stipules free, semi-amplexicaul. Staminate inflorescences solitary or in pairs, spicate to subcapitate, with an abaxial sterile groove, pedunculate, with (sub)peltate bracts; flowers few to many; perianth 4-parted, segments decussateimbricate; stamens inflexed, at anthesis bending outward elastically, anthers introrse; pistillode quadrangular. Pistillate inflorescences solitary or in pairs (occasionally 3 together), 1 or 2 flowers sessile at the end of the peduncle with (sub)peltate bracts; perianth tubular, 4-lobed; ovary adnate to the perianth, style terminal, stigmas 2, equal. In fruit perianth enlarged, fleshy and red; endocarp thin-crustaceous, at the seed-bearing side with a more or less prominent longitudinal woody crest; seed with a split corresponding with the crest; testa thin, with a thickened oblong vascularized part below the small hilum, in the middle with a fold protruding into the split; embryo longitudinally aligned, cotyledons very unequal, the smaller one flat and reniform, the larger one thick and conduplicate, radicle subapical, short, straight.

The genus Maillardia was established by Duchartre (1863?). He used a manuscript of Frappier and adopted the genus name given by Frappier. The genus was placed in the Artocarpeae sensu Trécul (1847) (in spite of the presence of stamens inflexed in the bud and springing back at anthesis) and regarded as related to the neotropical genera Olmedia and Pseudolmedia. For the epitheton Duchartre did not adopt the name lancifolia given by Frappier. Until $1948 \mathrm{M}$. borbonica was the only described species. Then Léandri (1948b) described the apparently rather common Madagascan representatives of Maillardia under four names. However, only one Madagascan species can be distinguished. To this species also belongs the material collected on the Aldabra Atoll for which Fosberg (1974) proposed a new species.

Maillardia belongs to a group of chiefly Asian and American genera in which the perianth of the pistillate flower is tubular, in fruit fleshy, reddish or black, and fused with the fruit. By virtue of this it is clearly distinguished from the other African Moreae. Corner (1962) reduced Maillardia (and the Asian genus Calpidochlamys) to sections of Trophis subg. Trophis. The two neotropical genera (Sorocea and Clarisia) with 
the same type of pistillate flower were kept separate. These two genera are distinct as their stamens are not inflexed in bud and do not spring back at anthesis. As stated before (see p. 334), Corner's decision might prove to be correct, but further study of the members of Trophis s.l., as well as of Sorocea, Clarisia, and Olmedia (cf. Berg 1977) appears to be necessary before more definite decisions can be reached.

The two species of Maillardia are very closely interrelated. The main differences are in the leaves.

The minute warts (in young leaves) and dots (in older leaves) are caused by cystoliths (cf. Léandri 1948b).

\section{Key to the species of Maillardia}

1.a. Stipules (4-)6-15 mm long; leaves with a sharp acumen . . 1. $M$. borbonica b. Stipules 1-3 mm long; leaves with a blunt acumen . . . . 2. M. montana

17.1. Maillardia borbonica Duchartre, Notes sur l'île de la Réunion, Annexe P. : 3 (1863?); De Cordemoy, Flore de l'île de la Réunion: 275 (1895). - Syntypes : Frappier 279 and s.n. (several sterile, staminate and fruiting collections), Réunion (P). - Fig. 26.

Trees up to $7 \mathrm{~m}$ tall; leafy twigs $1-4 \mathrm{~mm}$ thick, glabrous. Leaves elliptic to oblong, broadest in or below the middle, $2-11 \mathrm{~cm}$ long, $0.7-4 \mathrm{~cm}$ broad, coriaceous, sharply acuminate to subcaudate, at the base acute to obtuse; margin entire, often slightly revolute; above and beneath glabrous, above more or less distinctly minutely tuberculate to punctate; the costa almost plane, the other veins more or less prominent above, the veins prominent beneath, 6-18 pairs of secondary veins, without parallel tertiary veins; petioles (2-)4-12 mm long, glabrous; stipules (4-)6-15 mm long, glabrous. Staminate inflorescences mostly solitary, $2-3.5 \mathrm{~cm}$ long, including the ca. $1 \mathrm{~mm}$ long, sparsely puberulous and bracteate peduncle; usually more flowers than in $M$. montana, the floral parts and bracts similar to those of $M$. montana, except for the sparsely puberulous perianth. Pistillate inflorescences solitary; peduncle 5-11 mm long, sparsely puberulous to almost glabrous; a single flower at the end of the peduncle; floral parts similar to those of $M$. montana; bracts spread or crowded at the upper end of the peduncle, (sub)peltate, suborbicular to elliptic, up to ca. $2 \mathrm{~mm}$ long, glabrous. In fruit perianth oblongoid, ca. $17 \times 8 \mathrm{~mm}$, apiculate; endocarp body ca. $15 \times 7 \mathrm{~mm}$; seed ca. $12 \times 5 \mathrm{~mm}$. 


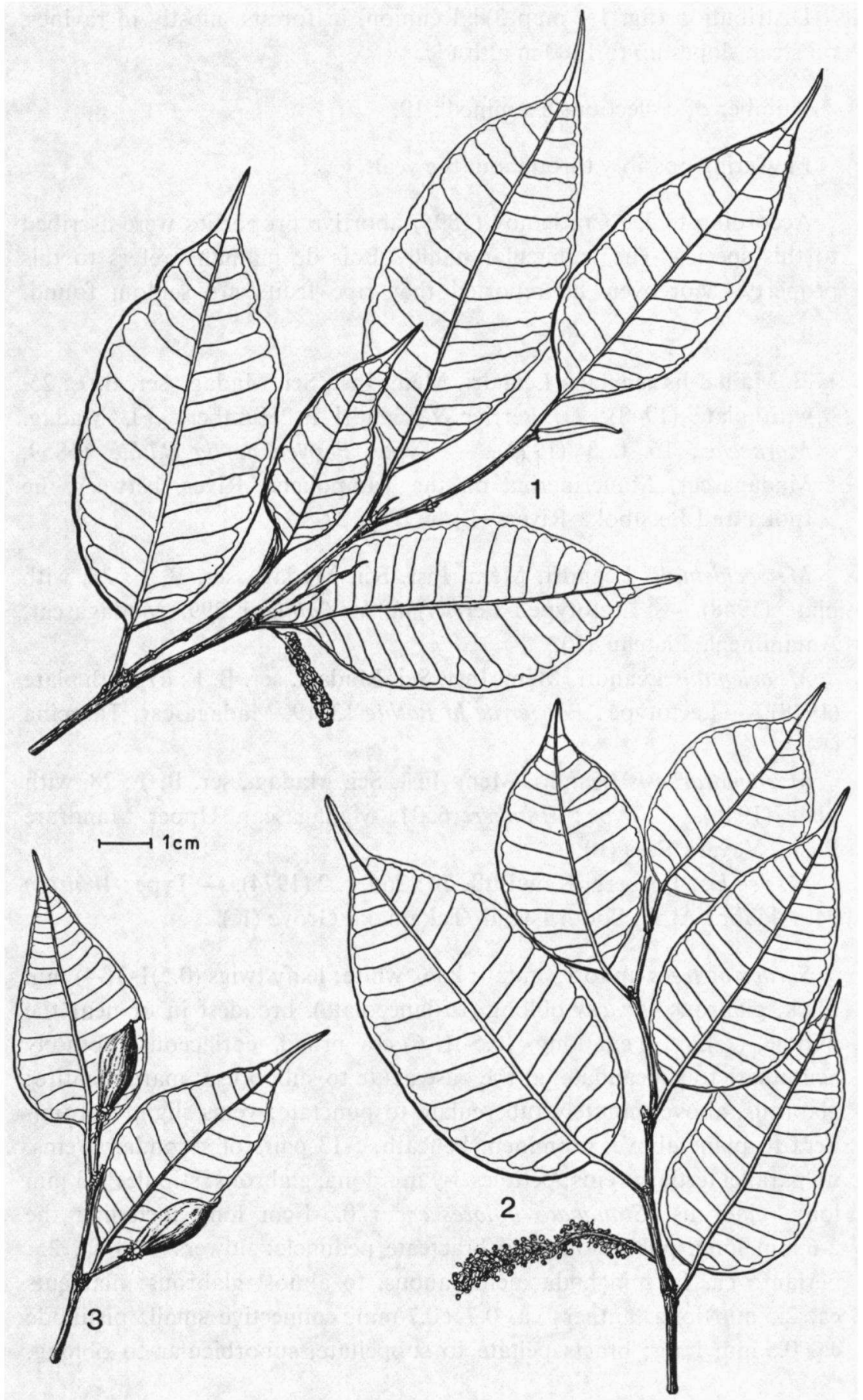

Fig. 26. - Maillardia borbonica: 1, leafy twig with young staminate inflorescence (Capuron 28237); 2, leafy twig with staminate inflorescence (Friedmann 1232); 3, leafy twig with young infructescences (Friedmann 1071). 
Distribution (fig. 15, map 3): Réunion, in forests, mostly in ravines, on steep slopes up to $1300 \mathrm{~m}$ altitude.

Number of collections examined : 19.

Flowering possibly throughout the year.

According to De Cordemoy (1895) abortive proporties were ascribed to this species. The vernacular name "Bois de maman" refers to this property. Moreover, he reported that ripe fruits are seldom found.

17.2. Maillardia montana Léandri, Mém. Inst. Sci. Madag., ser. B, $1: 25$, with plate (1948); H. Perrier \& Léandri in Humbert, Fl. Madag. Moraceae: 16, t. 3 (1952). - Type: Perrier de la Bâthie 16859, Madagascar, Manerinerina on the Tampoketsa River, between the Ipoka and Betsiboka Rivers (P). - Fig. 27.

M. occidentalis Léandri, Mém. Inst. Sci. Madag., ser. B, $1: 26$, with plate (1948). - Lectotype: Perrier de la Bâthie 12399, Madagascar, Antanimena Plateau (P).

M. orientalis Léandri, Mém. Inst. Sci. Madag., ser. B, $1: 27$, with plate (1948). - Lectotype : Perrier de la Bâthie 13319, Madagascar, Tampina (P).

M. mandrarensis Léandri, Mém. Inst. Sci. Madag., ser. B, $1: 28$, with plate (1948). - Type: Humbert 6531, Madagascar, Upper Mandrare Basin, Vavara Pass (P).

M. pendula Fosberg, Kew Bull. 29 : 266, t. 2 (1974). - Type: Whitton 94, Aldabra Atoll, South Island, Takamaka Grove (K).

Shrubs or trees up to $15 \mathrm{~m}$ tall; latex white; leafy twigs $(0.5) 1-3(-4) \mathrm{mm}$ thick, glabrous. Leaves oblong (to lanceolate), broadest in or near the middle, (1-) $2(-13) \mathrm{cm}$ long, $(0.5-) 1(-6) \mathrm{cm}$ broad, coriaceous, obtusely acuminate to subcaudate, at the base acute to subobtuse; margin entire; glabrous, above minutely tuberculate to punctate; veins slightly prominent to plane above, prominent beneath, 5-13 pairs of secondary veins, no parallel tertiary veins; petioles 3-9 $\mathrm{mm}$ long, glabrous; stipules $1-3 \mathrm{~mm}$ long, glabrous. Staminate inflorescences $0.5-1 \mathrm{~cm}$ long including the 2-6 mm long, puberulous and bracteate peduncle; flowers 6 to ca. 25; perianth ca. $1.5 \mathrm{~mm}$ high, membranous, to almost glabrous; filaments ca. $2.5 \mathrm{~mm}$ long, anthers ca. $0.7 \times 0.7 \mathrm{~mm}$, connective small; pistillode ca. $0.5 \mathrm{~mm}$ long; bracts peltate to subpeltate, suborbicular to oblong, 


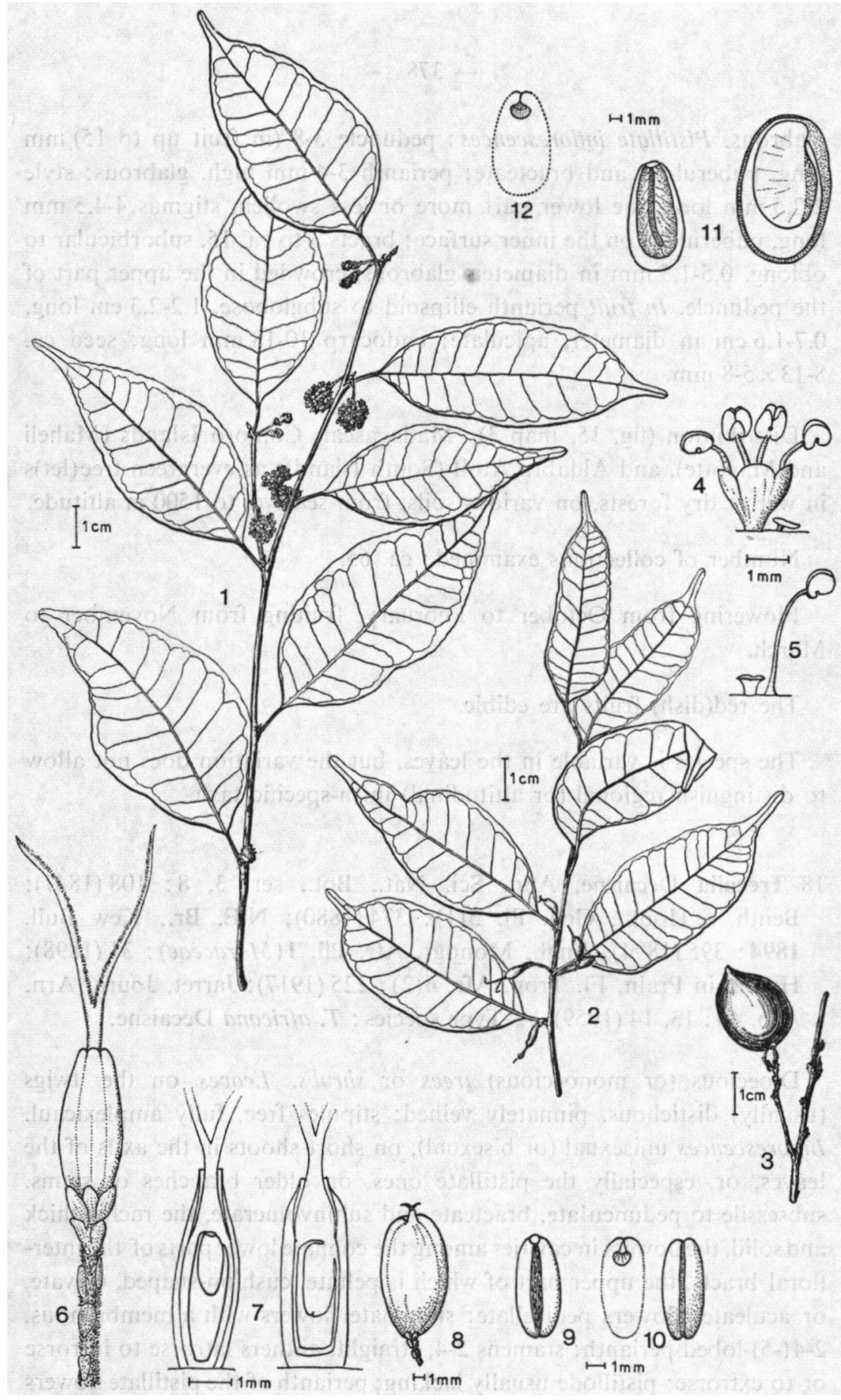

Fig. 27. - Maillardia montana: 1, leafy twig with staminate inflorescences; 2, leafy twig with pistillate flowers; 3 , infructescence; 4 , staminate flower and bract; 5 , pistillode and stamen; 6, pistillate inflorescence; 7, pistillate flower; 8, infructescence; 9, seed, 10, embryo; 11, seed; 12, small cotyledon (1: Capuron 18831 ; 2, 6, 7: Perrier de la Báthie 17863; 3, 11, 12: Capuron 27407; 4, 5: Serv. For. Madag. 6430; 8-10: Léandri 555). 
glabrous. Pistillate inflorescences: peduncle 3-8 (in fruit up to 15) $\mathrm{mm}$ long, puberulous and bracteate; perianth $3-4 \mathrm{~mm}$ high, glabrous; style 2-2.5 mm long, the lower part more or less swollen, stigmas $4-4.5 \mathrm{~mm}$ long, puberulous on the inner surface; bracts 3 to ca. 15, suborbicular to oblong, $0.5-1.5 \mathrm{~mm}$ in diameten glabrous, crowded in the upper part of the peduncle. In fruit perianth ellipsoid to subglobose, $1.2-2.3 \mathrm{~cm}$ long, $0.7-1.6 \mathrm{~cm}$ in diameter, apiculate; endocarp $10-18 \mathrm{~mm}$ long; seed ca. 8-13 $\times 5-8 \mathrm{~mm}$.

Distribution (fig. 15, map 3): Madagascar, Comoro Islands (Maheli and Mayotte), and Aldabra Atoll (South Island); as evergreen tree(let)s in wet or dry forests, on various soils, from sealevel to $1500 \mathrm{~m}$ altitude.

Number of collections examined : ca. 65 .

Flowering from October to February, fruiting from November to March.

The red(dish) fruits are edible.

The species is variable in the leaves, but the variation does not allow to distinguish regional (or altitudinal) infra-specific taxa.

18. Treculia Decaisne, Ann. Sci. Nat., Bot., ser. 3, 8: 108 (1847); Benth. \& Hook., Gen. Pl. 3(1): 374 (1880); N.E. Br., Kew Bull. 1894: 395 (1894); Engl., Monogr. Afr. Pfl. 1(Moraceae): 31 (1898); Hutch. in Prain, Fl. Trop. Afr. 6(2): 225 (1917); Jarret, Journ. Arn. Arb. 40 : 13, 14 (1959). - Type species : T. africana Decaisne.

Dioecious (or monoecious) trees or shrubs. Leaves on the twigs (usually) distichous, pinnately veined; stipules free, fully amplexicaul. Inflorescences unisexual (or bisexual), on short shoots in the axils of the leaves, or, especially the pistillate ones, on older branches or stems, subsessile to pedunculate, bracteate and subinvolucrate, the rachis thick and solid, the flowers in cavities among the connate lower parts of the interfloral bracts, the upper part of which is peltate, cushion-shaped, clavate, or aculeate; flowers pedicellate; staminate flowers with a membranous, 2-4(-5)-lobed perianth; stamens 2-4, straight, anthers latrorse to introrse or to extrorse; pistillode usually lacking; perianth of the pistillate flowers (probably) lacking; ovary free; style with 2 filiform stigmas. In fruit the upper parts of the interfloral bracts hardened; the fruits in a (rather) 
soft layer; endocarp crustaceous, exocarp firm and coriaceous or weak and more or less fleshy; testa rather thick, with an orbicular thickened vascularized part below the small hilum; embryo curved, cotyledons unequal, the smaller one plane and enclosed by the thick larger one or strongly reduced; radicle short and apical, remains of endosperm mainly in the apical part of the seed.

The genus Treculia, with the only species $T$. africana, was established by Decaisne in Trécul's monographic treatment of the "Artocarpées" (1847). Baillon (1875) added a second species, $T$. acuminata, and placed it in the section Pseudotreculia. N.E. Brown (1894) described three Treculia species, $T$. affona, $T$. madagascarica, and $T$. obovoidea, which were not mentioned in Engler's monographic treatment of African Moraceae (1898). Later about ten more species were described in the genus by Engler (1898, 1908), De Wildeman \& Durand (1899, 1900), De Wildeman (1914), Jumelle (1920), and Léandri (1948a).

In 1908 Engler described the genus Acanthotreculia, with $A$. winkleri. Hutchinson (1917) recognized the type of $A$. winkleri as female material of the species which Engler (1898) had previously described from male specimens as T. staudtii and N.E. Brown (1894) as T. obovoidea. In 1897 Engler named some new Treculia species and placed them in the section Microtreculia, based on differences in the anthers. He soon (1898) relalized that these species were related to $T$. acuminata, and consequently re-established Baillon's section Pseudotreculia, inserting in it all the species he recognized exept $T$. africana. Material of $T$. africana has been described as a species of Ficus (Stapf 1909) and Artocarpus (Sim 1909).

Treculia comprises three species, the widespread and (especially on Madagascar) variable $T$. africana with several infra-specific taxa, and the less variable and more restricted $T$. acuminata and $T$. obovoidea. The differences between $T$. africana and the latter two species justify retention of Engler's subdivision of the genus (Engler 1898). T. acuminata and $T$. obovoidea are very closely interrelated.

There is a contrast in the areas of $T$. africana and the two species of sect. Pseudotreculia. The former matches the large areas of the tall arborescent Moraceae extending more or less far outside the rain forest areas, the two other species share the small areas of many small-sized components of the humid rain forest.

As stated before (p. 334), Treculia shows striking morphological similarities to the Asian genus Parartocarpus (cf. Jarrett 1959, 1960; Corner 1962). Poisonous properties reported for latex and seeds ("fruits") 
of T. africana may also indicate close relationship to Parartocarpus (cf. Jarrett 1960).

Inflorescences: The inflorescences are borne on more or less distinct short-shoots bearing fused and modified stipules. Male specimens of T. acuminata usually have short-shoots up to ca. $1 \mathrm{~mm}$ long, which bear a large number of inflorescences appearing successively. In $T$. africana and $T$. obovoidea the pistillate inflorescences are mostly born below the leaves on older branches, in $T$. africana even on the trunk. The staminate inflorescences can often be found in the axils of the leaves. $T$. acuminata and $T$. obovoidea are dioecious. $T$. africana may be monoecious. Moreover, inflorescences of $T$. africana are sometimes bisexual, having staminate flowers in the lower part and pistillate flowers in the upper part, or staminate flowers spread over the inflorescence and preceding the pistillate flowers in flowering. In the pistillate inflorescences of $T$. africana abortive staminate flowers can usually be found. In $T$. africana the inflorescences of the two sexes are very similar. They are globose, obovoid, or broadly clavate. The short peduncle bears several to many basally attached bracts subtending the inflorescence and forming an involucre. The interfloral bracts are basically peltate. Their lower parts are fused. In pistillate inflorescences they become longer by intercalary growth in the fused parts. Cavities left among the bracts contain the pedicellate flowers. The pedicels are completely or only basally fused with the surrounding (lower part of the) bracts. Two types of interfloral bracts can be distinguished: the first formed ones as primary interfloral bracts, and those which develop later towards the cavities as secondary interfloral bracts. In $T$. africana the secondary bracts are smaller and the smallest ones are often not distinctly peltate. In $T$. obovoidea the primary bracts are (almost) cushion-shaped and gradually pass into the aculeate secondary ones. In $T$. acuminata the primary bracts are either peltate or ovoid to aculeate. As a rule they gradually pass into the aculeate (to subulate) secondary bracts, but in staminate inflorescences the secondary bracts may also be peltate. In inflorescences of $T$. acuminata bracts of all shapes from peltate to obovoid to clavate to subulate to aculeate may be found. The "spines" of the infructescences of $T$. acuminata and $T$. obovoidea are formed by the elongated and indurated aculeate bracts. The primary bracts of $T$. obovoidea also form "spines", but they are usually shorter than those formed by the secondary bracts. Peltate bracts do not appear to form "spines".

Pistillate flowers: The pistillate flowers lack a perianth as far as could 
be observed in examining the material without anatomical study. The pedicels are completely fused with the surrounding tissue of the fused lower parts of the interfloral bracts. In $T$. africana the flowers do not mature simultaneously. As the interfloral bracts still elongate during anthesis in the inflorescence, the flowers are situated at different distances from the rachis and have pedicels of different length. This results in sufficient room being available for the numerous fruits in the infructescence. Elongation of the bracts also leads to shedding of the style, the infructescence then being covered by loose styles. In $T$. acuminata and $T$. obovoidea the pistillate flowers of each inflorescence flower almost simultaneously.

Staminate flowers: The staminate flowers have a membranous perianth. The number of stamens varies from (1-)2 to 4 . Flowers of the same inflorescence may differ in the number of stamens. The anthers of $T$. africana are relatively long and narrow and introrse; they are attached to the filament in the upper half and sometimes near the top. The anthers of $T$. acuminata and $T$. obovoidea are relatively short and broad, latrorse to introrse (in T. obovoidea) or to extrorse (in T. acuminata). Pistillodes may be present. Abortive staminate flowers occur in most pistillate inflorescences of $T$. africana; their pedicels are almost completely fused with the bracts.

In $T$. africana before anhesis the flowers are enclosed in the cavities among the bracts, but they are raised on their long pedicels; in the other two species the pedicels are very short or almost lacking.

Infructescences: The fruits are imbedded in a layer formed by the fused parts of the interfloral bracts. This layer is rather soft and more or less mucilaginous in $T$. africana, more solid in $T$. acuminata and $T$. obovoidea. The basal part of the fruit is fused with the surrounding tissue. The more or less indurated free parts of the bracts form a protective layer consisting of "spines" in T. acuminata and T. obovoidea.

The fruits of $T$. africana differ from those of $T$. acuminata and $T$. obovoidea. The exocarp is thinly fleshy (-when dry membranous-) in $T$. africana, but coriaceous in the latter two species. In these two species the endocarp bears dense hair-like structures (probably remains of cell-walls) in a more or less gelatinous layer between endocarp and exocarp. The endocarp is crustaceous. The seed contains remains of endosperm, especially in its apical part, around the radicle and below the thickened vascularized part of the testa, and also between the cotyledons, especially in $T$. africana. The embryo occupies a longitudinal position. 
In $T$. africana the smaller cotyledon varies in length considerably. In $T$. acuminata and $T$. obovoidea one of the cotyledons is strongly reduced and completely enclosed by the larger cotyledon.

\section{Key to the species of Treculia}

1.a. Lamina usually more or less inequilateral; inflorescences only with peltate interfloral bracts, the staminate ones at least $5 \mathrm{~mm}$ in diam.; anthers long and narrow .................... . . africana

b. Lamina not or hardly inequilateral; inflorescences usually with aculeate interfloral bracts; if only peltate bracts present, the staminate inflorescences at most $5 \mathrm{~mm}$ in diam.; anthers short and broad . . . . . . . . . 2

2.a. Shrubs; the costa beneath with sparse uncinate hairs; "spines" of the infructescence up to $0.5 \mathrm{~cm}$ long . . . . . . . . . . 2. T. acuminata

b. Trees; the costa beneath only with appressed straight hairs; "spines" of the infructescence up to $2 \mathrm{~cm}$ long . . . . . . . . 3. T. obovoidea

\section{A. Treculia Decaisne sect. Treculia}

Dioecious or (often?) monoecious trees. Inflorescences sometimes bisexual, the pistillate ones usually with abortive staminate flowers; interfloral bracts peltate; anthers long, narrow, and introrse. Fruit with a thinly fleshy exocarp.

18.1. Treculia africana Decaisne, Ann. Sci. Nat., Bot., ser. 3, 8: 109, t. 3 (1847); Hook., Bot. Mag. : t. 5986 (1872); Engl., Monogr. Afr. Pfl. 1 (Moraceae) : 32, t. 12, 13 (1898); De Wild. \& Th. Dur., Ann. Mus. Congo, Bot., ser. 1, 1 : 139 (1900); Hutch. in Prain, Fl. Trop. Afr. 6(2): 227 (1917); Andrews, Fl. Pl. Anglo-Egyptian Sudan 2: 273, t. 97(1952); Aubrév., Fl. For. Côte d'Ivoire 1 : 58, t. 7 (1959). - Type: Heudelot s.n., "Senegambia" (P).

The variation of $T$. africana in the African continent is rather continuous; the hairy form presently still distinguished as var. mollis may prove not to be taxonomically distinct. In Madagascar the representatives show more and discontinuous variation, but as a whole they do not show important morphological differences if compared with the continental ones. Some of the Madagascan specimens can hardly be distinguished from continental ones. Distinction of a continental and a Madagascan subspecies is mainly based on the different variation patterns in connection with geographical aspects, and because of the fact that discontinuities in variation allow subdivision of the Madagascan segregate. Each of the subspecies is fully described below. 


\section{1.a. Treculia africana Decaisne ssp. africana}

Dioecious or sometimes monoecious trees, up to $30(-50) \mathrm{m}$ tall; latex white, turning brownish; leafy twigs $2-6 \mathrm{~mm}$ thick, (rather) sparsely puberulous to almost glabrous or hirtellous to (sub)tomentose. Leaves oblong to lanceolate, sometimes elliptic, broadest in or below the middle, more or less inequilateral (distinctly inequilateral at the base), (5-)10-25(-50) cm long, (2.5-) 4-12(-20) $\mathrm{cm}$ broad, coriaceous (to subcoriaceous), acuminate to apiculate, sometimes subacute, at the base obtuse to cordate, or sometimes one half (sub)acute and the other half obtuse, occasionally both halves acute; margin entire or faintly repand (dentate in saplings); above glabrous or nearly so, beneath often sparse uncinate hairs on the secondary veins or beneath hirtellous to subtomentose; veins slightly prominent to plane above, more or less prominent beneath, (8-)10-(-18) pairs of secondary veins, no or some parallel tertiary veins; petioles $2-14 \mathrm{~mm}$ long, glabrous, sparsely appressed-puberulous or substrigose (often the periderm peeling off); stipules $10-18 \mathrm{~mm}$ long, almost glabrous or puberulous to hirtellous, caducous. Staminate inflorescences mostly solitary, sometimes paired on short-shoots in the axils of the leaves or on older (already leafless) twigs or branches, globose to ellipsoid or to obovoid, $2.5-10 \mathrm{~cm}$ in diam., subsessile to pedunculate; peduncle up to $4 \mathrm{~mm}$ long, bearing several rows of (sub)reniform to elliptic, basally attached, outside glabrous or sparsely appressed-puberulous, ciliolate bracts; flowers numerous, solitary in the cavities of the inflorescence; pedicel 1-20 mm long; perianth 3-6 mm high, membranous, 2(-3)-lobed to -fid, (almost) glabrous; stamens 2 , often 3, or sometimes 4 , filaments $5-12 \mathrm{~mm}$ long, anthers $2-4.5 \mathrm{~mm}$ long, $0.4-0.7 \mathrm{~mm}$ broad, attached to the filament about 1/3-1/4 from the apex, (versatile?), connective narrow, often with a puberulous apiculus; interfloral bracts with a 2-6 mm long, more or less clavate, sparsely puberulous to glabrous stipe, narrowed towards the insertion of the peltate part, peltate part $0.2-5 \mathrm{~mm}$ in diam., ciliolate and often appressed-puberulous. Pistillate inflorescences solitary or in pairs on distinct short-shoots, usually below the leaves on older branches or on the trunk, globose to obovoid (rather variable in dimensions, probably at least $2.5 \mathrm{~cm}$ in diam.); peduncle short, bearing in 4-6 series many basally attached, depressed-semicircular to elliptic, coriaceous, ciliolate, outside sparsely puberulous to glabrous bracts; flowers numerous; ovary ca. 1-1.5 cm high, style up to10 mm long, puberulous, stigmas $3-5(-10) \mathrm{mm}$ long; interfloral bracts $4-5 \mathrm{~mm}$ long, similar to those of the staminate inflorescence; the cavities contain- 
ing the pistillate flowers invested with short hairs; among the bracts usually up to $1 \mathrm{~mm}$ long, shortly pedicellate, abortive staminate flowers which may have a subulate pistillode. Infructescences (sub)globose, up to $30 \mathrm{~cm}$ in diam., the rachis surrounded by a $7-8 \mathrm{~cm}$ broad layer of elongate lower parts of the interfloral bracts, the outer part of this layer for the greater part consisting of the indurated free upper parts of the bracts sometimes having lost their peltate parts, the inner part of the layer soft and more or less mucilaginous containing (more or less scattered) the fruits; fruits $10-15 \mathrm{~mm}$ long, the exocarp thinly fleshy, the endocarp often with an apical dent.

18.1.a'. Treculia africana Decaisne ssp. africana var. africana. - Fig. $28 \& 30$.

T. affona N.E. Br., Kew Bull. 1894 : 360 (1894); Hutch. in Prain, Fl. Trop. Afr. 6(2) : 227 (1917). — Type : Millson s.n., Nigeria, Yorubaland $(\mathrm{K}$; isotypes $\mathrm{B}, \mathrm{E})$.

T. africana var. nitida Engl., Monogr. Afr. Pfl. 1 (Moraceae) : 33 (1898); Hutch. in Prain, Fl. Trop. Afr. 6(2) : 227 (1917). — Type : Lehmbach 3a, Cameroun (B).

T. deweurei De Wild. \& Th. Dur., Ann. Mus. Congo, Bot., ser. 2, 1 : 54 (1899); De Wild. \& Th. Dur., Ann. Mus. Congo, Bot., ser. 1, 1 : 139, t. 70 (1900); De Wild. \& Th. Dur., Ann. Mus. Congo, Bot., ser. 3, 1 : 217 (1901). - Type : Dewèvre s.n., Zaire, near Umangi (BR).

T. engleriana De Wild. \& Th. Dur., Ann. Mus. Congo, Bot., ser. 1, 1 : 140 (1900). — Type : Gillet s.n., Zaire, Kisantu (BR).

T. africana var. engleriana (De Wild. \& Th. Dur.) Engl., Pflanzenw. Afr. 3(1): 30, t. 8 (1915).

Ficus whytei Stapf in Johnston, Liberia 2: 650 (1906). - Type: Whyte 21, Liberia, Sinoe Basin, near Kuvu (K; isotype BM).

Artocarpus? africanus Sim, For. Fl. Port. E. Afr. : 102, t. 32 (1909). Type: $\operatorname{Sim}$ 3999, Moçambique (not yet traced).

Treculia centralis A. Chev., Etud. Fl. Afr. Centr. Fr. 1 : 292 (1913), nom. (sub)nud.

T. erinacea A. Chev., Etud. Fl. Afr. Centr. Fr. 1: 292 (1913), nom. (sub)nud.

Myriopeltis edulis Welw. (MSS) mentioned by Hook., Bot. Mag. : $t$. 5986 (1872), nomen. 


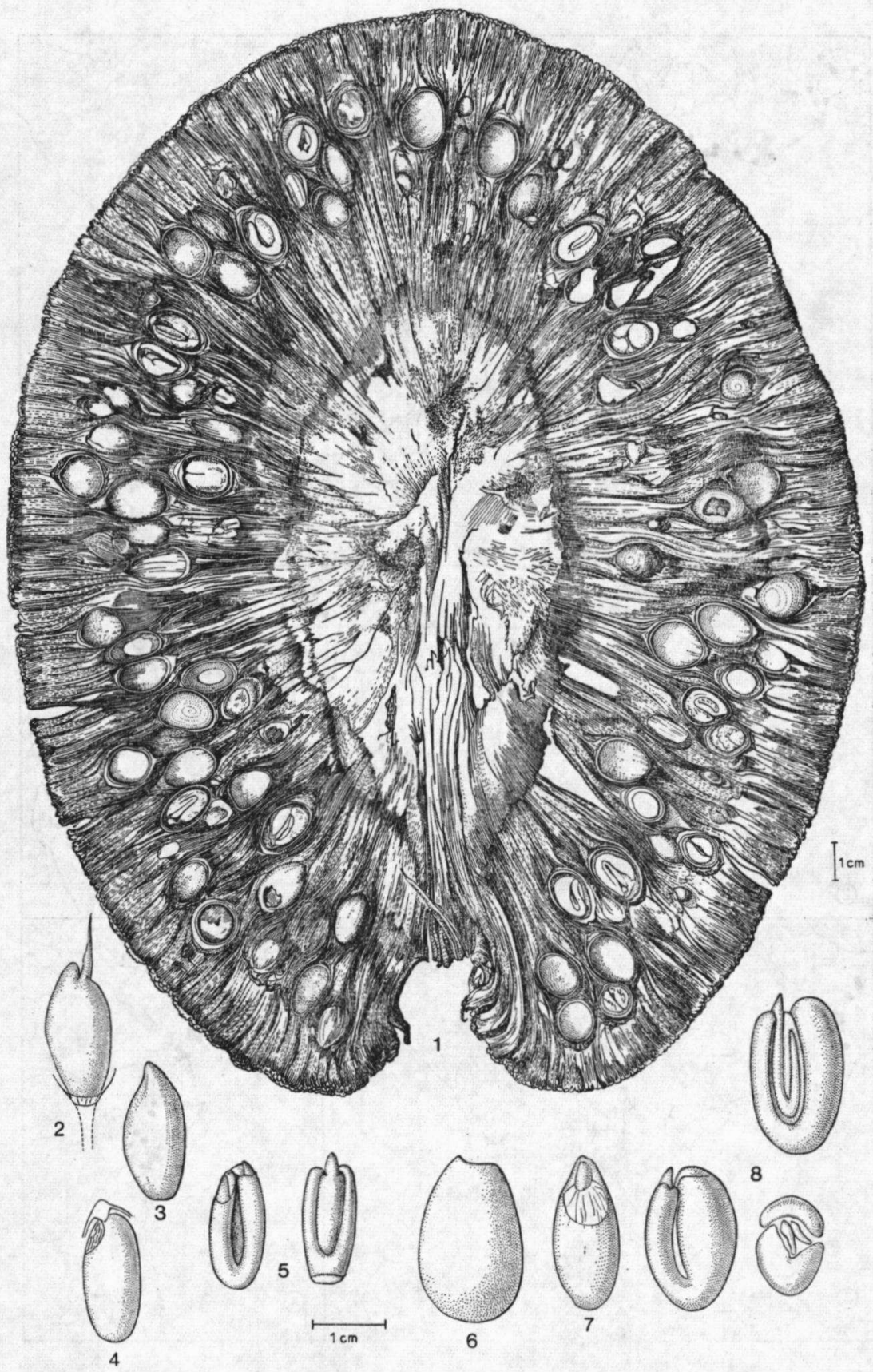

Fig. 28. - Treculia africana ssp. madagascarica var. ilicifolia: 1, infructescenco (Capuron 6894). - Treculia africana ssp. africana var. africana: 2, fruit; 3, endocarp body; 4 , seed; 5 , embryo; 6 , endocarp body; 7 , seed; 8 , embryo (2-5: Leeuwenberg 10217; 6-8: Esperito Santo 5). 


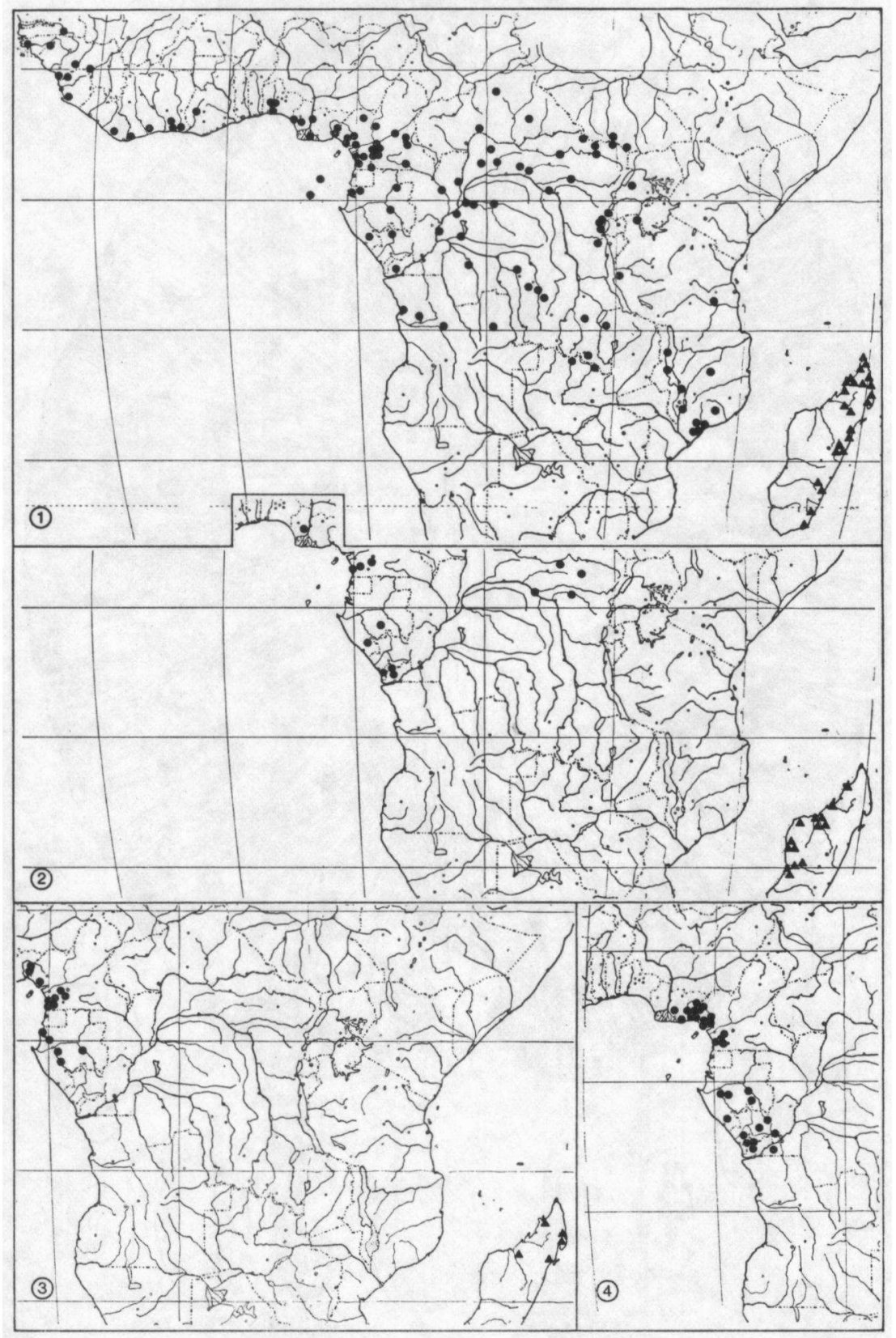

Fig. 29. - Distribution of taxa of Treculia : map 1, T. africana ssp. africana var. africana, A $T$. africana ssp. madagascarica var. madagascarica; map. $2, T$. africana ssp. africana var. mollis, $\Delta T$. africana ssp. madagascarica var. ilicifolia; map 3 , A $T$. africana ssp. madagascarica var. sambiranensis, $T$. acuminata; map $4, T$. obovoidea. 
Ficus welwitschii Miq. (MSS) mentioned by Hook., Bot. Mag. : t. 5986 (1872), nomen.

Leafy twigs sparsely puberulous to almost glabrous. Leaves with lower surface glabrous or nearly so, the secondary veins often with a few uncinate hairs; stipules almost glabrous.

Distribution (fig. 29, map 1): From Senegal to southern Sudan, southward to Angola and to central Moçambique, also on São Tomé; as evergreen (or sometimes deciduous?) trees in humid to dry primary forest, preferring riversides or regionally almost confined to them, also on rocks in riverbeds, in swamp forests, in secondary forests, or cultivated; regionally abundant to rare; from sealevel to $1300 \mathrm{~m}$.

Number of collections examined : ca. 250.

The flowering times could not be established, There may be regionally different (main) flowering times, but the material is too scarce for establishing them.

The wood is said to be a good timber. The oil-containing seeds are consumed; they can be ground to meal and the oil can be extracted. The infructescences are eaten by various animals : elephants (cf. Brown 1894), antelopes, and large forest snails (Hutchinson \& Dalziel 1937). Fruits are said to be poisonous for horses, sheep, and goats (cf. Hutchinson 1917).

Corner (1962) associated the infructescences of Treculia africana with those of Artocarpus species, and with the analogous Durian fruit. Because of the structure of the infructescence and the properties of the fruits $T$. africana may be also be brought into connection with the Durian fruit with regard to dispersal (cf. van der Pijl 1972). It is often reported on labels that the staminate inflorescences are highly scented. The sweet odour may be pleasant, but as a rule it is reported as unpleasant to disgusting and reminiscent of aceton, rotten apples, etc. It is uncertain whether the unpleasant odour is produced in all stages or only when the inflorescence is old. Germain (coll. 303) reported that the bad smell is released after cutting the staminate inflorescences. According to Leeuwenberg (coll. 2435) the inflorescences may be inhabited by beetles and grubs. This suggests that the staminate inflorescences may function as broodplaces and, moreover, that $T$. africana resembles the cauliflorous Artocarpus heterophyllus in the way of pollination (cf. van der Pijl 1953). 
Seedlings of $T$. africana show a distichous arrangement of the leaves from the youngest stages; the first pair of normal leaves are opposite, the following ones distichous.

Young staminate and pistillate inflorescences cannot be distinguished. In these inflorescences several primary interfloral peltate bracts are conspicuous by their dimensions and in dried material by their darker colour; the largest is usually at the top of the inflorescence. In fruit the interfloral bracts sometimes shed their peltate upper parts. In staminate inflorescences the whole perianth of the staminate flower may exceed the bracts or only their upper parts.

The variation in the number of stamens, used to distinguish separate species (De Wildeman \& Th. Durand 1900) proved not to be taxonomically significant. Variation in the number of stamens can even occur in the same inflorescence, as already stated by Engler (1915) and Hutchinson (1917).

18.1.a'. Treculia africana Decaisne ssp. africana var. mollis (Engl.) J. Léonard. - Type: Zenker 3333, Cameroun, near Bipinde (B; isotypes $\mathrm{E}, \mathrm{G})$. - Fig. 30.

T. mollis Engl., Bot. Jahrb. 40 : 546 (1908); Hutch. in Prain, Fl. Trop. Afr. 6(2): 229 (1917).

T. africana var. mollis (Engl.) J. Léonard, Bull. Jard. Bot. Etat Brux. 18 : 145 (1947); Hauman, Fl. Congo, Ruanda-Urundi 1 : 91 (1948).

Leafy twigs hirtellous to (sub)tomentose. Leaves with lower surface hirtellous to (sub)tomentose; stipules puberulous to hirtellous.

Distribution (fig. 29, map 2): Known from some more or less isolated localities in Zaire, Gabon, Cameroun, and Nigeria.

Number of collections examined : ca. 25 .

$T$. mollis was distinguished on the basis of a dense tomentose to hirtellous indument on leaves, twigs, and stipules (Engler 1908). This species was reduced to a variety of $T$. africana by J. Leonard (1947). The present material is too scanty to establish if there are also constant differences in inflorescences and flowers between this variety and the typical variety. But it does not seem likely. This as well as the distribution of var. mollis suggest that the taxonomical value of the differences in the indument is small and that the form hardly merits recognition. 


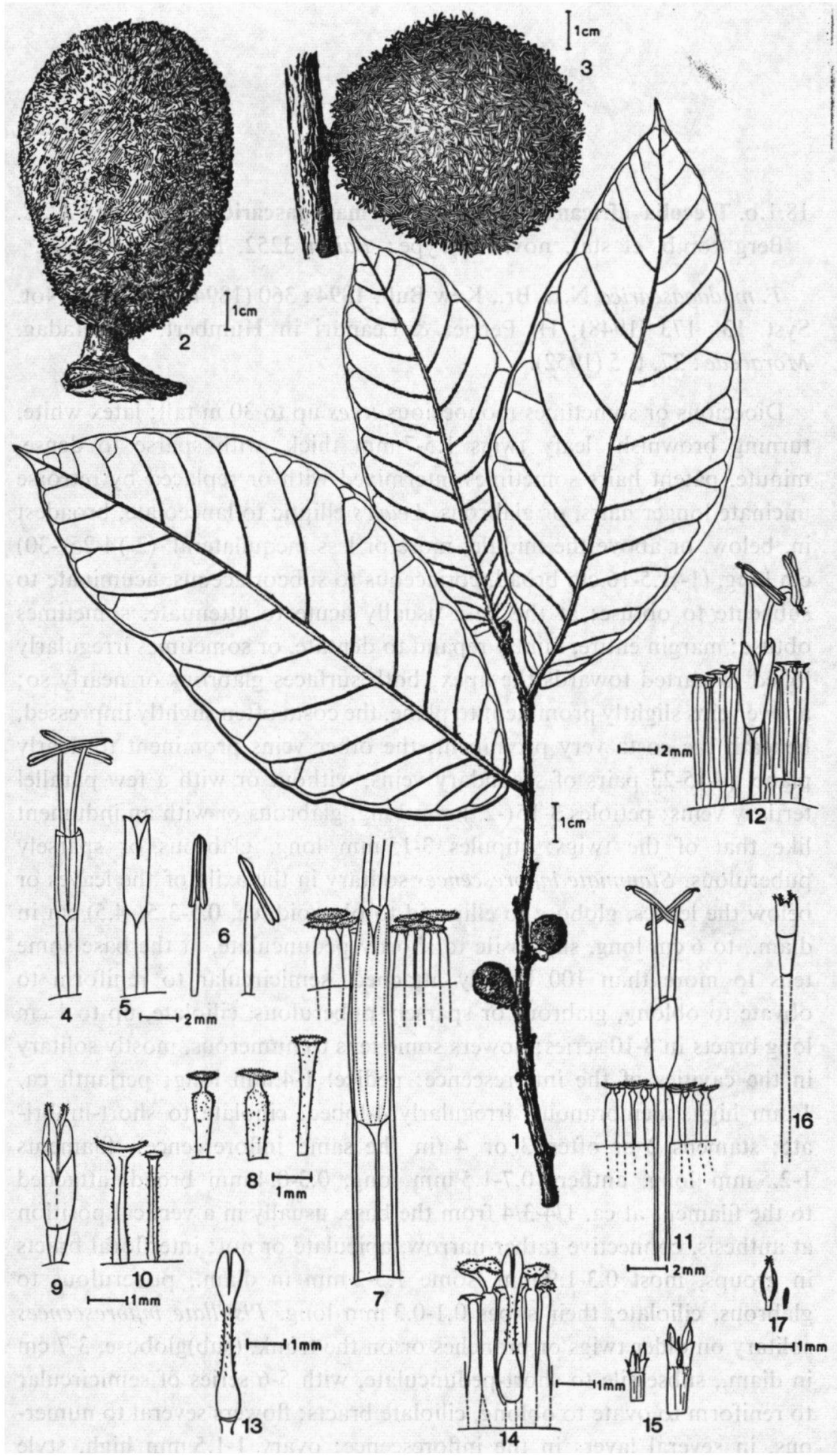

Fig. 30. - Treculla africana ssp. africana var. mollis : 1 , leafy twig with inflorescences (Benoit Mpom 134). - Treculia africana ssp. africana var. africana: 2 \& 3, staminate inflorescences; 4 , staminate flower; 5 , perianth; 6 , stamens; $7 \& 8$, bracts of staminate flower; 9, staminate flower; 10, id., bracts; 11 \& 12, staminate flowers and bracts; 13 , young pistillate flower; 14, id., bract; 15 , abortive staminate flower; 16 , abortive staminate flower (in pistillate inforescence); 17, stamen and pistillode of abortive flower $(2:$ Le Testu $3848 ; 3,11$ : de Wilde $2605 ; 4-8$ : de Wilde $2662 ; 9,10$ : Callens 2886; 12: Zenker 2525; 13-15: Le Testu 3831; 16, 17 : Leeuwenberg 10217). 
18.1.b. Treculia africana Decaisne ssp. madagascarica (N.E. Br.) C.C. Berg comb. et stat. nov: - Type: Baron 3252, Madagascar (K).

T. madagascarica N.E. Br., Kew Bull. 1894 : 360 (1894); Léandri, Not. Syst. 13: 173 (1948); H. Perrier \& Léandri in Humbert; Fl. Madag. Moraceae : 27, t. 5 (1952).

Dioecious or sometimes monoecious trees up to $30 \mathrm{~m}$ tall; latex white, turning brownish; leafy twigs $1.5-7 \mathrm{~mm}$ thick, with sparse to dense, minute, patent hairs sometimes intermixed with or replaced by retrorse uncinate longer hairs, or glabrous. Leaves elliptic to lanceolate, broadest in, below, or above the middle, more or less inequilateral, (2-)4-25(-30) cm long, (1-) $1.5-16 \mathrm{~cm}$ broad, coriaceous to subcoriaceous, acuminate to subacute to obtuse; at the base usually acute to attenuate, sometimes obtuse; margin entire, faintly repand to dentate, or sometimes irregularly lobed to parted towards the apex; both surfaces glabrous or nearly so; above veins slightly prominent to plane, the costa often slightly impressed, beneath the costa very prominent, the other veins prominent to nearly plane, (4-)5-23 pairs of secondary veins, without or with a few parallel tertiary veins; petioles $3-15(-25) \mathrm{mm}$ long, glabrous or with an indument like that of the twigs; stipules $3-15 \mathrm{~mm}$ long, glabrous or sparsely puberulous. Staminate inflorescences solitary in the axils of the leaves or below the leaves, globose to ellipsoid to obovoid, ca. $0.5-3.5(-4.5) \mathrm{cm}$ in diam., to $6 \mathrm{~cm}$ long, subsessile to shortly pedunculate, at the base some tens to more than 100 basally attached, semicircular to reniform to obvate to oblong, glabrous or sparsely puberulous, ciliolate, up to $1 \mathrm{~cm}$ long bracts in 8-10 series; flowers some tens to numerous, mostly solitary in the cavities of the inflorescence; pedicel $1-4 \mathrm{~mm}$ long; perianth ca. $1 \mathrm{~mm}$ high, membranous, irregularly 4-lobed, ciliolate to short-fimbriate; stamens 2 or often 3 or 4 (in the same inflorescence), filaments $1-2.5 \mathrm{~mm}$ long, anthers $0.7-1.5 \mathrm{~mm}$ long, $0.3-0.4 \mathrm{~mm}$ broad, attached to the filament at ca. 1/4-3/4 from the base, usually in a vertical position at anthesis, connective rather narrow, apiculate or not; interfloral bracts in groups, most $0.3-1.9 \mathrm{~mm}$, some $1.5-2 \mathrm{~mm}$ in diam., puberulous to glabrous, ciliolate, their stipes $0.1-0.3 \mathrm{~mm}$ long. Pistillate inflorescences solitary on older twigs or branches or on the trunk, (sub)globose, 3-7 cm in diam., subsessile to short-pedunculate, with 5-6 series of semicircular to reniform to ovate to oblong, ciliolate bracts; flowers several to numerous, in several layers in the inflorescence; ovary 1-1.5 mm high, style to $6-13 \mathrm{~mm}$ long, usually sparsely hairy, stigmas up to $18 \mathrm{~mm}$ long, of equal or unequal length, sometimes one of the stigmas strongly reduced; 
interfloral bracts with 1-2 $\mathrm{mm}$ long puberulous stipes narrowed towards the insertion of the peltate part of the bract, which is ca. $0.5-1.5 \mathrm{~mm}$ in diam. or in a few bracts up to $3 \mathrm{~mm}$ in diam., puberulous. Infructescences globose to oblongoid or ovoid, up to $40 \mathrm{~cm}$ long, up to $40 \mathrm{~cm}$ in diam., sometimes irregularly furrowed, the layer containing the fruits up to $8 \mathrm{~cm}$ broad; fruits ellipsoid, $15-18 \mathrm{~mm}$ long, seed similar to that of ssp. africana; the peltate parts of the bracts persisting in fruit.

Distribution (fig. 29, maps 1-3): Madagascar, as evergreen or caducous trees in humid to dry forests (or thickets), mainly along streams, also in sublittoral forests, on various soils, but probably not on calcareous soils; from sealevel to $1300 \mathrm{~m}$.

Number of collections examined : ca. 75 .

According to Perrier de la Bâthie (coll. 9996) the latex is poisonous.

Three varieties can be distinguished, mainly on differences of the leaves. In northern Madagascar the three varieties occur together. Var. madagascarica, in the northern part of the island also occurring on the western side, extends southward along the eastern side of the island to near Fort Dauphin. Var. ilicifolia, confined to the western part of Madagascar, extends southward to the region between the Tsiribihina and Mangoky Rivers. Var. sambiranensis is confined to northern Madagascar and occurs there both on the eastern and the western side.

18.1.b'. Treculia africana Decaisne ssp. madagascarica (N.E. Br.) C.C. Berg var. madagascarica. - Fig. 31.

Leaves variously shaped, mostly oblong, sometimes lanceolate or elliptic, mostly $1.5-5 \mathrm{~cm}$ broad, with up to 15 pairs of secondary veins; margin mostly entire, sometimes lobed, sometimes more or less undulate; apex acute to acuminate, often abruptly acuminate, sometimes lobed towards the apex. Twigs glabrous, with only retrorse uncinate hairs, or also with minute patent hairs. Staminate inflorescences $0.5-2 \mathrm{~cm}$ in diam.

Distribution : see p. 386.

Number of specimens examined : ca. 45.

This variety is less homogenous in the leaf characters than the other two varieties and comprises forms passing into them. 


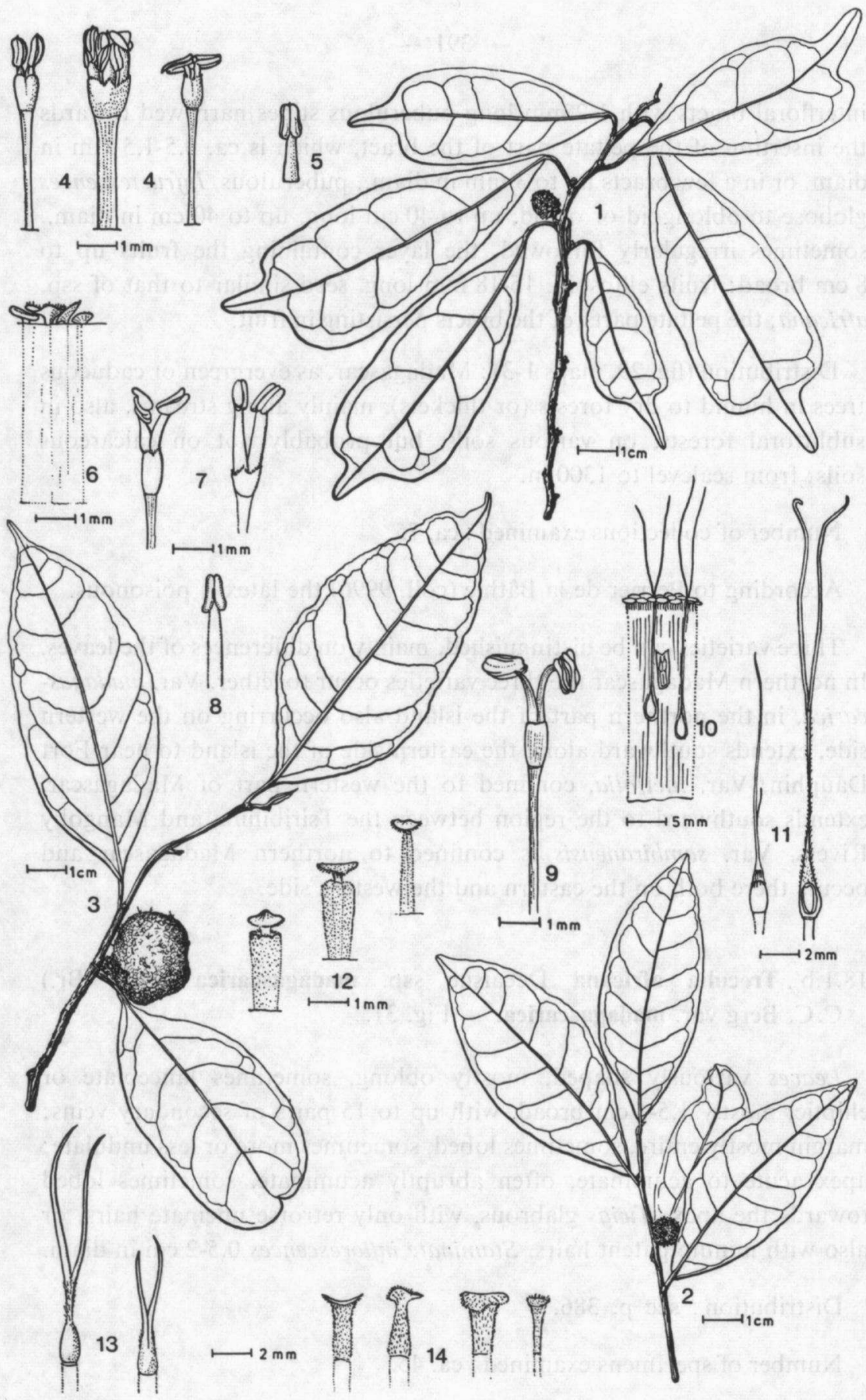

Fig. 31. - Treculia africana ssp. madagascarica var. madagascarica: 1, leafy twig with staminate inflorescence; 2 , leafy twig with staminate inflorescence; 3 , leafy twig with pistillate inflorescence; 4, staminate flowers; 5 , stamen; 6, bracts of staminate flower; 7, staminate flowers; 8, stamen; 9, staminate flower; 10, part of pistillate inflorescence with abortive staminate flower; 11, pistillate flowers; 12, id., bracts: 13, pistillate flowers; 14, id., bracts (1, 7, 8: Capuron 24858; 2: Saboureau 4406; 3: Capuron 11455; 4-6: Serv. For. Madag. 7891; 9 : Decary 14728; 10-12: Capuron 8676; 13, 14 : Perrier de la Bathle 10063). 


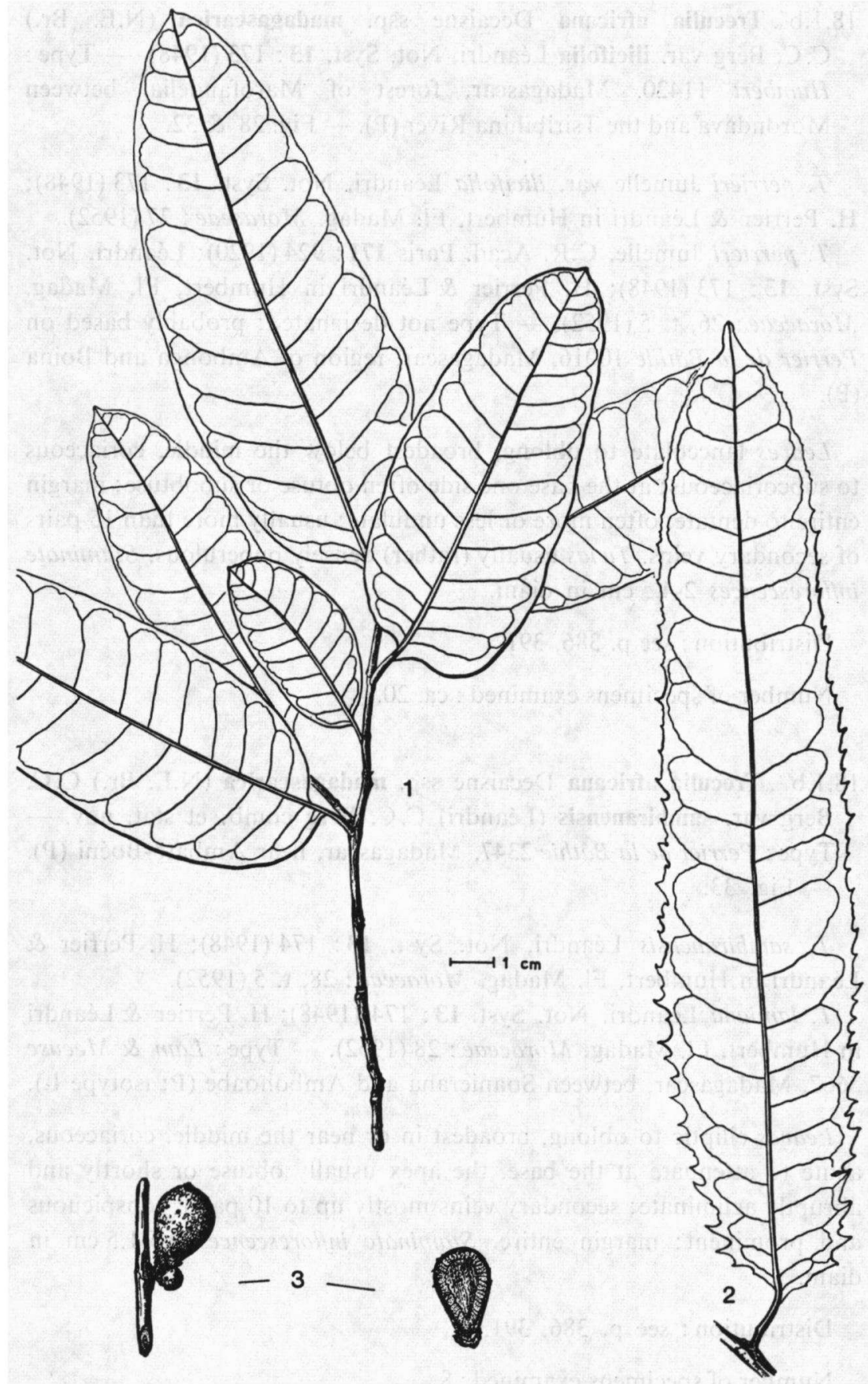

Fig. 32. - Treculia africana ssp. madagascarica var. ilicifolia: 1, leaves (Capuron 6894); 2, leaf (Perrier de la Bâthie 13899); 3, staminate inflorescences (Humbert 11420). 
18.1.b". Treculia africana Decaisne ssp. madagascarica (N.E. Br.)

C.C. Berg var. ilicifolia Léandri, Not. Syst. 13 : 173 (1948). - Type : Humbert 11420, Madagascar, forest of Marofandelia, between Morondava and the Tsiribihina River (P). - Fig. 28 \& 32.

T. perrieri Jumelle var. ilicifolia Léandri, Not. Syst. 13 : 173 (1948); H. Perrier \& Léandri in Humbert, Fl. Madag. Moraceae : 27 (1952).

T. perrieri Jumelle, C.R. Acad. Paris 171 : 924 (1920); Léandri, Not. Syst. 13 : 173 (1948); H. Perrier \& Léandri in Humbert, Fl. Madag. Moraceae : 26, t. 5 (1952). - Type not designated; probably based on Perrier de la Bâthie 10016, Madagascar, region of Ambonga and Boina (P).

Leaves lanceolate to oblong, broadest below the middle, coriaceous to subcoriaceous; at the base one side often obtuse or subobtuse; margin entire to dentate, often more or less undulate; usually more than 15 pairs of secondary veins. Twigs usually (rather) densely puberulous. Staminate inflorescences $2-4.5 \mathrm{~cm}$ in diam.

Distribution : see p. $386,391$.

Number of specimens examined : ca. 20.

18.1. $\mathrm{b}^{\prime \prime \prime}$. Treculia africana Decaisne ssp. madagascarica (N.E. Br.) C.C. Berg var. sambiranensis (Léandri) C.C. Berg comb. et stat. nov. Type : Perrier de la Bâthie 2347, Madagascar, near Ambato-Boéni (P). - Fig. 33.

T. sambiranensis Léandri, Not. Syst. 13: 174 (1948); H. Perrier \& Léandri in Humbert, Fl. Madag. Moraceae : 28, t. 5 (1952).

T. lamiana Léandri, Not. Syst. 13 : 174 (1948); H. Perrier \& Léandri in Humbert, Fl. Madag. Moraceae : 28 (1952). - Type : Lam \& Meeuse 5667, Madagascar, between Soanierana and Ambohoabe (P; isotype L).

Leaves elliptic to oblong, broadest in or near the middle, coriaceous, acute to attenuate at the base, the apex usually obtuse or shortly and abruptly acuminate; secondary veins mostly up to 10 pairs, conspicuous and prominent; margin entire. Staminate inflorescences $0.5-1.5 \mathrm{~cm}$ in diam.

Distribution : see p. $386,391$.

Number of specimens examined : 8 . 


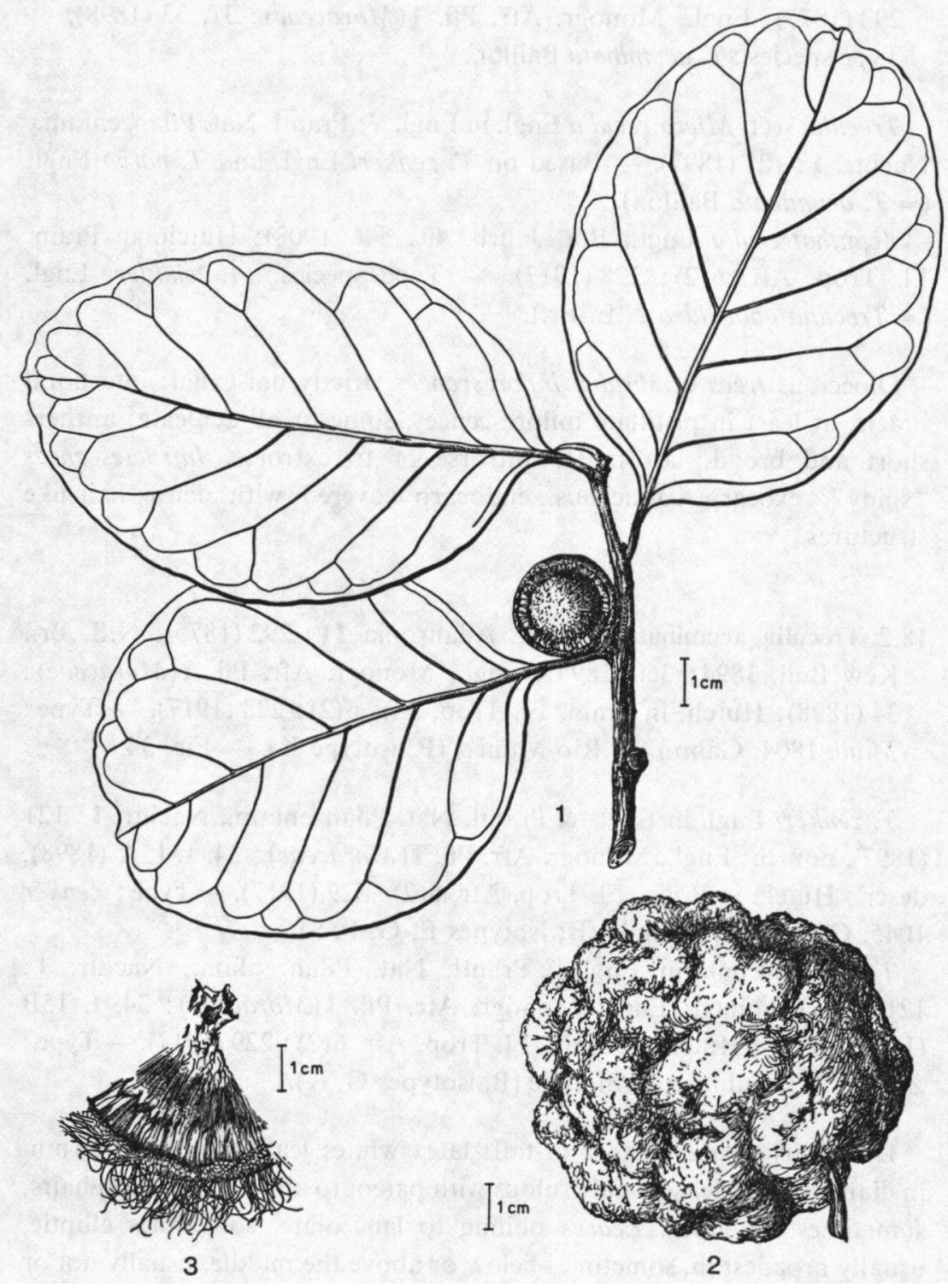

Fig. 33. - Treculia africana ssp. madagascarica var. sambiranensis: 1 , leafy twig with pistillate inflorescence (Capuron 8676); 2, infructescence (Humbert \& Capuron 22394); 3 , part of inflorescence (Capuron 8676). 
18.B. Treculia Decaisne sect. Pseudotreculia Baillon, Adansonia 11 : 292 (1875); Engl., Monogr. Afr. Pfl. 1(Moraceae) : 31, 33 (1898). — Type species : T. acuminata Baillon.

Treculia sect. Microtreculia Engl. in Engl. \& Prantl, Nat. Pflanzenfam., Nachtr. 1 : 121 (1897). - Based on T. zenkeri Engl. and T. parva Engl. ( $=T$. acuminata Baillon).

Acanthotreculia Engl., Bot. Jahrb. 40 : 546 (1908); Hutch. in Prain, Fl. Trop. Afr. 6(2): 228 (1917). - Type species: A. winkleri Engl. (= Treculia obovoidea N.E. Br.).

Dioecious trees or shrubs. Inflorescences strictly unisexual; interfloral bracts, at least in pistillate inflorescences, some or all aculeate; anthers short and broad, latrorse to introrse or to extrorse. Infructescences "spiny"; exocarp coriaceous, endocarp covered with dense hair-like structures.

18.2. Treculia acuminata Baillon, Adansonia 11 : 292 (1875); N.E. Br., Kew Bull. 1894 : 360 (1894); Engl., Monogr. Afr. Pfl. 1(Moraceae): 34 (1898); Hutch. in Prain, Fl. Trop. Afr. 6(2) : 228 (1917). - Type : Mann 1804, Gabon (or Rio Muni?) (P; isotype K). - Fig. 34.

T. zenkeri Engl. in Engl. \& Prantl, Nat. Pflanzenfam., Nachtr. 1 : 121 (1897), nomen; Engl., Monogr. Afr. Pfl. 1(Moraceae) : 34, t. 15A (1898), descr.; Hutch. in Prain, Fl. Trop. Afr. 6(2) : 229 (1917). - Type : Zenker 1045, Cameroun, Bipinde (B; isotypes E, G, P, S).

T. parva Engl. in Engl. \& Prantl, Nat. Pflanzenfam., Nachtr. 1 : 121 (1897), nomen; Engl., Monogr. Afr. Pfl. 1(Moraceae): 34, t. 15B (1898), descr.; Hutch. in Prain, Fl. Trop. Afr. 6(2): 229 (1917). - Type: Zenker 983, Cameroun, Bipinde (B, isotypes $\mathrm{G}, \mathrm{K}$ ).

Dioecious shrubs up to $3 \mathrm{~m}$ tall; latex white; leafy twigs $1-3(-6) \mathrm{mm}$ in diam., rather densely puberulous with patent to almost appressed hairs, sometimes hirtellous. Leaves oblong to lanceolate, sometimes elliptic, usually broadest in, sometimes below or above the middle, usually not or hardly inequilateral, (3.5-)6-24 cm long, (1.5-) $2.5-8 \mathrm{~cm}$ broad, chartaceous (to subcoriaceous), acuminate to caudate, at the base acute to obtuse; margin entire; above glabrous, beneath on the costa and the secondary veins sparsely puberulous, partly with uncinate hairs, glabrescent; veins plane to slightly prominent above, prominent beneath, 


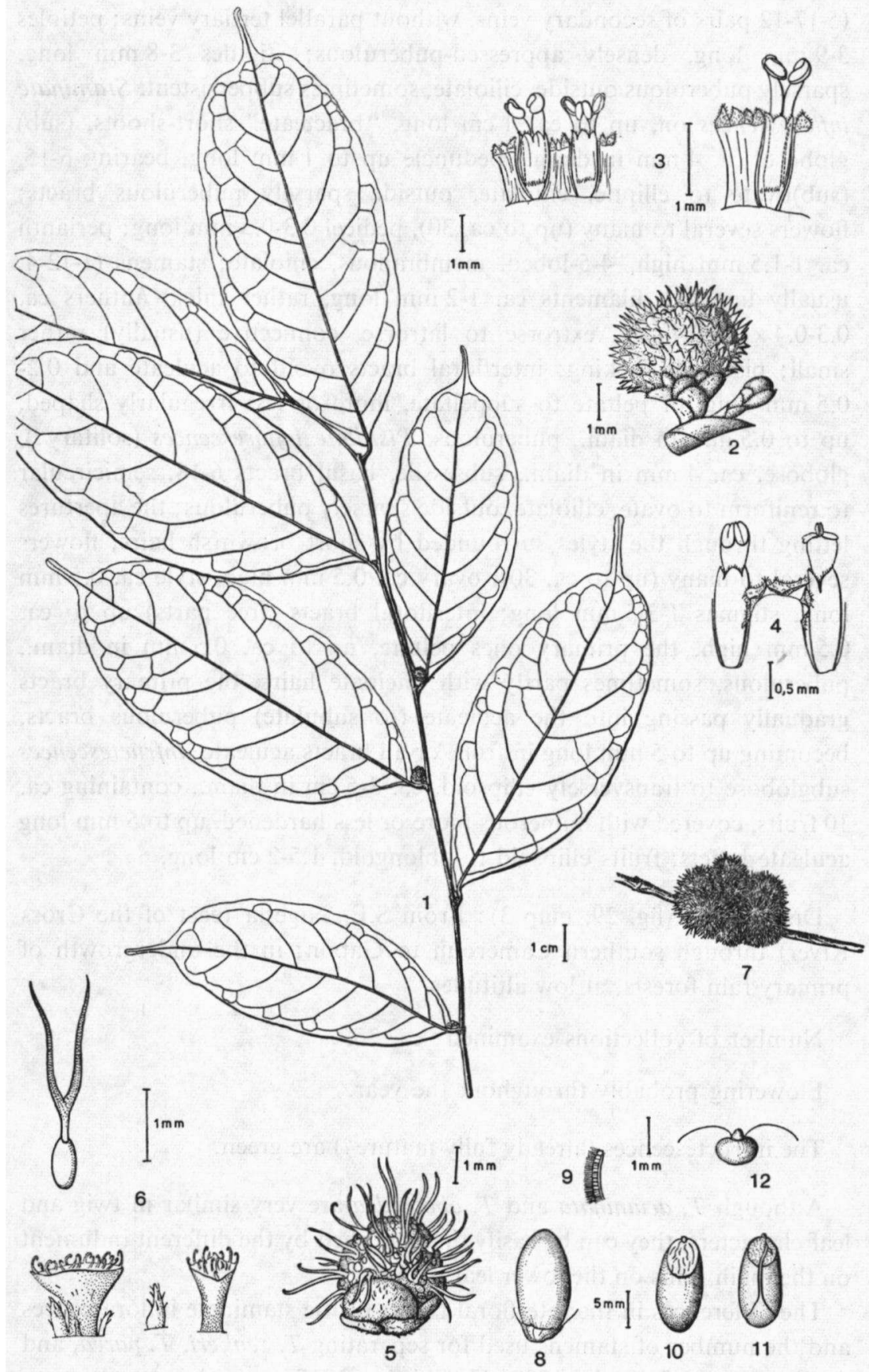

Fig. 34. - Treculia acuminata: 1 , leafy twig with staminate inflorescences; 2 , staminate inflorescences, one very young, the other just before anthesis; $3 \& 4$, staminate flowers and bracts; 5 , pistillate inflorescence; 6 , pistil and bracts; 7 , infructescence; 8 , fruit; 9, testa, endocarp and layer with hair-like structures; 10 , seed, 11, embryo; 12 , small cotyledon (1: Klaine 2174; 2 : Klaine $966 ; 3$ : Breteler 5724; 4 : de Wilde 1448; 5, 6 : Letouzey 12357; 7 : Klaine 3004; 8-12: Walker s.n.). 
(5-)7-12 pairs of secondary veins, without parallel tertiary veins; petioles 3-9 $\mathrm{mm}$ long, densely appressed-puberulous; stipules 3-8 $\mathrm{mm}$ long, sparsely puberulous outside, ciliolate, sometimes subpersistent. Staminate inflorescences on, up to ca. $1 \mathrm{~cm}$ long, "bracteate" short-shoots, (sub) globose, ca. $4 \mathrm{~mm}$ in diam.; peduncle up to $1 \mathrm{~mm}$ long, bearing 6-15, (sub)ovate to elliptic, ciliolate, outside sparsely puberulous bracts; flowers several to many (up to ca. 30), pedicel $0.3-0.5 \mathrm{~mm}$ long; perianth ca. 1-1.5 mm high, 4-5-lobed, membranous, ciliolate; stamens (1-)2-4, usually unequal, filaments ca. $1-2 \mathrm{~mm}$ long, rather thick, anthers ca. $0.3-0.4 \times 0.3-0.4 \mathrm{~mm}$, extrorse to latrorse, connective (usually) rather small; pistillode lacking; interfloral bracts ovoid to aculeate and $\mathbf{0 . 2 -}$ $0.5 \mathrm{~mm}$ long, or peltate to subpeltate, more or less irregularly shaped, up to $0.5 \mathrm{~mm}$ in diam., puberulous. Pistillate inflorescences (solitary?), globose, ca. $4 \mathrm{~mm}$ in diam., subsessile, basal bracts 6-18, semicircular to reniform to ovate, ciliolate, outside sparsely puberulous; the apertures letting through the styles surrounded by short brownish hairs; flowers several to many (up to ca. 30); ovary ca. $0.5 \mathrm{~mm}$ high, style ca. $0.5 \mathrm{~mm}$ long, stigmas 1-3.5 mm long; interfloral bracts (free parts) up to ca. $0.5 \mathrm{~mm}$ high, the primary ones peltate, up to ca. $0.5 \mathrm{~mm}$ in diam., puberulous, sometimes partly with uncinate hairs, the primary bracts gradually passing into the aculeate (to subulate) puberulous bracts, becoming up to $5 \mathrm{~mm}$ long in fruit, or all bracts aculeate. Infructescences subglobose to transversely ellipsoid, ca. $3-5 \mathrm{~cm}$ in diam., containing ca. 10 fruits, covered with numerous more or less hardened, up to $5 \mathrm{~mm}$ long aculeate bracts; fruits ellipsoid to oblongoid, $1.5-2 \mathrm{~cm}$ long.

Distribution (fig. 29, map 3): From S.E. Nigeria (east of the Cross River) through southern Cameroun to Gabon; in the undergrowth of primary rain forests, at low altitudes.

Number of collections examined : ca. 35.

Flowering probably throughout the year.

The infructescences (already fully mature?) are green.

Although $T$. acuminata and $T$. obovoidea are very similar in twig and leaf characters, they can be easily distinguished by the different indument on the main veins on the lower leaf surface.

The differences in the interfloral bracts of the staminate inflorescences and the number of stamens used for separating $T$. zenkeri, $T$. parva, and T. acuminata (cf. Engler 1898; Hutchinson 1917) proved not to be con- 
sistent. The staminate inflorescences may bear only peltate interfloral bracts, only obovoid to aculeate interfloral bracts, or a mixture of peltate and obovoid to aculeate interfloral bracts. In several specimens a series of transitions from peltate to aculeate bracts was found.

18.3. Treculia obovoidea N.E. Br., Kew Bull. 1894 : 361 (1894); Benth. \& Hook., Gen. Pl. 3(1): 375 (1880); Hauman, Fl. Congo, RuandaUrundi 1 : 92 (1948). — Lectotype : Mann 2303, Nigeria, (Old) Calabar River (K). - Fig. 35.

T. staudtii Engl. in Engl. \& Prantl, Nat. Pflanzenfam., Nachtr. 1 : 120 (1897), nomen; Engl., Monogr. Afr. Pfl. 1(Moraceae) : 33, t. 14B (1898), descr.; Hutch. in Prain, Fl. Trop. Afr. 6(2) : 228 (1917). - Type : Staudt 633, Cameroun, (Johan-Albrechtshöhe $=$ ) Kumba (B, not seen; isotypes COI, G).

T. staudtii var. augustifolia Engl., Monogr. Afr. Pfl. 1(Moraceae): 34 (1898). - Type : Staudt 270, Cameroun, Lolodorf, Mount Mbanga (B; isotypes COI, E, G, K, P, S).

Acanthotreculia winkleri Engl., Bot. Jahrb. 40: 548, t. 2 (1908); Engl., Pflanzenw. Afr. 3(1) : 30, t. 19 (1915); Hutch. in Prain, Fl. Trop. Afr. 6(2): 228 (1917). - Lectotype : Zenker 2295, Cameroun, Bipinde (B; isotypes BR, COI, K, L, P).

Treculia brieyi De Wild., Repert. Sp. Nov. 13 : 374 (1914), erroneously published as Trichilia brieyi; De Wild., Mission de Briey: 24 (1920); Hauman, Fl. Congo, Ruanda-Urundi 1 : 91 (1948).'- Type : de Briey 133, Zaire, Mayumbe, Ganda-Sundi (BR).

Dioecious trees up to $20 \mathrm{~m}$ tall; latex white turning brown or pinkish; leafy twigs $1.5-5 \mathrm{~mm}$ thick, (rather) sparsely appressed puberulous. Leaves oblong to lanceolate, broadest in or near the middle, not or slightly inequilateral, (3-)6-25 cm long, (1-)2-9 cm broad, chartaceous to subcoriaceous, acuminate to caudate, at the base acute to obtuse; margin (sub)entire; above glabrous, beneath sparsely appressed-puberulous on the costa and the secondary veins, glabrescent; veins plane to slightly prominent above, more or less prominent beneath, 7-16 pairs of secondary veins, without parallel tertiary veins; petioles 3-9 $\mathrm{mm}$ long; stipules 4-10 $\mathrm{mm}$ long, sparsely appressed puberulous and short-ciliate. Staminate inflorescences usually solitary, sometimes in pairs, occasionally several together in the leaf axils or below the leaves, obovoid, often almost oblongoid or ellipsoid, sometimes almost globose, $1-2.5 \mathrm{~cm}$ long, 


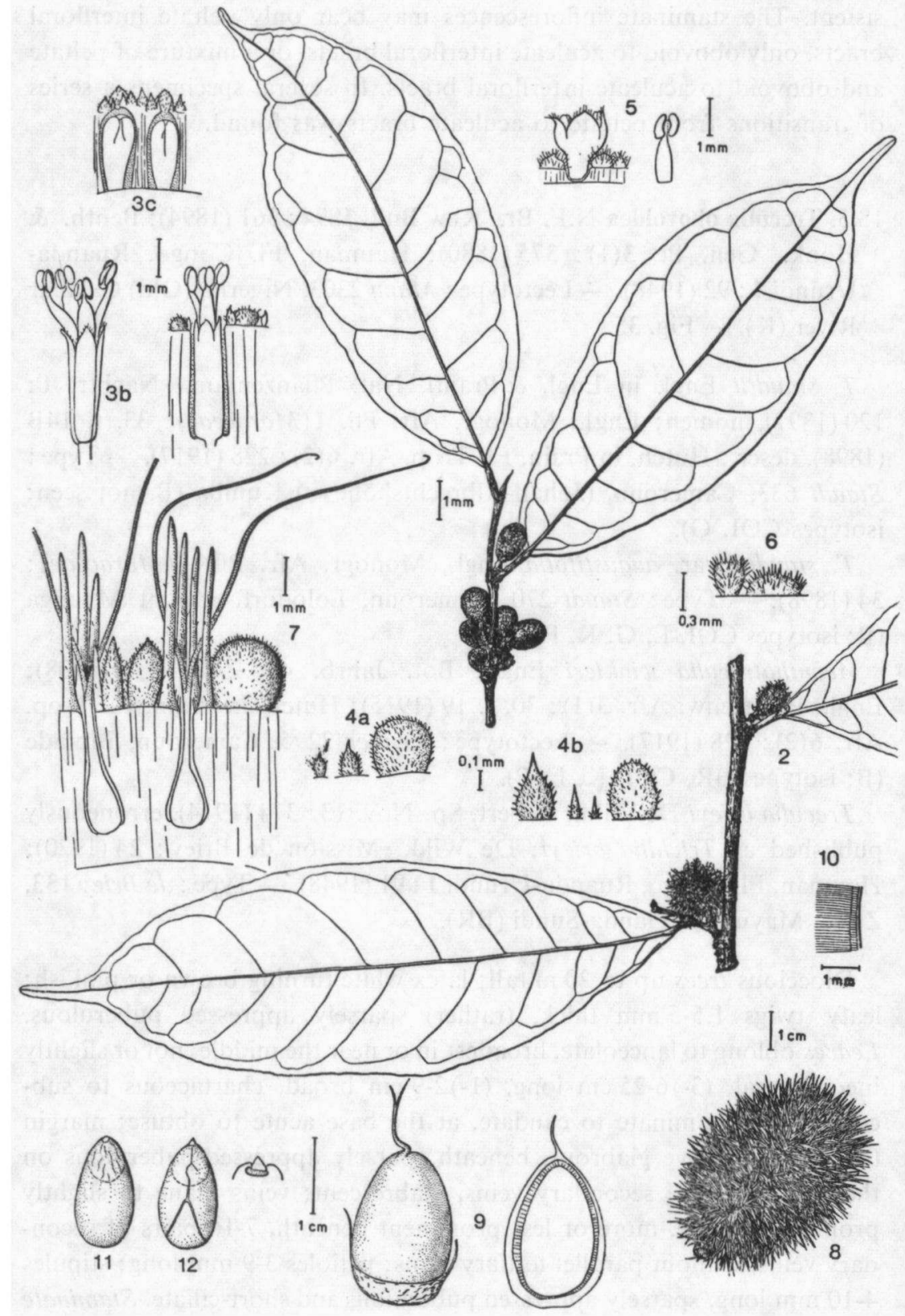

Fig. 35. - Treculia oboooidea: 1, leafy twig with staminate inflorescences; 2, leafy twig with pistillate inflorescences; $3 a \& b$, staminate flowers; $4 a \& b$, id., bracts; 5 , staminate flowers and stamen; 6, bracts of staminate flower; 7 , pistillate flowers and bracts; 8 , infructescence; 9 , fruit; 10, testa, endocarp and layer of hair-like structures; 11, seed; 12 embryo (1, 3, 4: Zenker 3776; 2, 7: Monteiro, Santos \& Murta 285; 5, 6: Staudt 633; 8-12: Leeuwenberg \& Berg 9719). 
$0.8-1.5 \mathrm{~cm}$ in diam., subsessile to pedunculate; peduncle up to $7 \mathrm{~mm}$ long, bearing 10-12, ovate, puberulous bracts; flowers numerous, sessile or subsessile; perianth $2.5-3 \mathrm{~mm}$ high, 3(-4)-lobed to 3(-4)-fid, membranous, glabrous except for the margin; stamens 3-4, usually unequal, filaments usually $3-4 \mathrm{~mm}$ long, anthers ca. $0.3-0.4 \times 0.3-0.4 \mathrm{~mm}$, latrorse (to introrse), connective narrow; pistillode subulate, $0.1-0.5 \mathrm{~mm}$ long or almost lacking; interfloral bracts numerous, up to $0.3 \mathrm{~mm}$ long, the primary ones more or less cushion-shaped and more or less densely puberulous, with or without an aculeate apex, the secondary ones, surrounding the apertures of the cavities, aculeate and only basally puberulous. Pistillate inflorescences solitary, sometimes in pairs behind the leaves, often on old branches or on the stem, (sub)globose, ca. $10 \mathrm{~mm}$ in diam.; peduncle up to $5 \mathrm{~mm}$ long; the apertures letting through the styles surrounded by hairs; flowers several to numerous; ovary ca. $1.5 \mathrm{~mm}$ long, style ca. $2 \mathrm{~mm}$ long, stigmas filiform, 6-9 mm long; the primary bracts cushion-shaped to subclavate, initially with or without an aculeate apex, up to $2 \mathrm{~mm}$ long, puberulous, passing gradually into the aculeate, up to $6 \mathrm{~mm}$ long, almost glabrous secondary bracts which surround the apertures letting through the styles. Infructescences globose to ellipsoid, $5-6.5 \mathrm{~cm}$ in diam., covered by the up to $\mathrm{ca} .2 \mathrm{~cm}$ long indurated aculeate bracts, the primary bracts usually shorter than the secondary bracts and sometimes (sub)clavate; fruits ellipsoid to oblongoid, $15-20 \mathrm{~mm}$ long.

Distribution (fig. 29, map 4) : From S.E. Nigeria (east of the Cross River) through southern Cameroun, Gabon, and western Congo to Angola-Cabinda and the adjacent part of Zaire; in primary or sometimes secondary rain forests, often (or mostly?) along streams, locally common, at low altitudes.

Number of collections examined : ca. 85 .

Flowering probably throughout the year.

The infructescences are pale yellow. The seeds are edible.

The species is uniform; variation of some importance is only found in the shape and dimensions of the staminate inflorescences and in the staminate flowers.

Acknowledgements: I am greatly indebted to Dr. K.U. Kramer, University of Zürich, for critically reading and correcting the English 
text, to Dr. A.L.M. Leeuwenberg, Agricultural University of Wageningen for his unforgettable hospitality and his help in studying Moraceae during my stay in Cameroun, and furthermore to Ir. J.W.A. Jansen for his hospitality and help during my visit to Togo, and to Ir. P.P.C. van Meer and Ir. V.J.M. Koch for their help during my visits to Nigeria and Ivory Coast, respectively. I should like to thank the directors and curators of the above listed herbaria, who made material available to me. The Netherlands Foundation for Advancement of Tropical Research (WOTRO) supplied grants for a visit to some West African countries and for visits to some European herbaria. The Miquel Foundation supplied a grant for a visit to the herbarium in Paris. The illustrations were prepared by Miss E.M. Hupkes van der Elst, Mr. T. Schipper, and Mr. W. Scheepmaker.

\section{REFERENCES}

Aubréville A. (1959) La Flore forestière de la Côte d'Ivoire, ed. 2, 1 : 336 p., 128 fig. Nogent-sur-Marne.

Aubréville A. et al. (1947) L'Iroko. Bois For. Trop. 1 (1) : 34-47.

Baillon H. (1863) Sur le Bosqueia, genre inédit de la famille des Artocarpées. Adansonia 3: 335-340, t. 10.

Baillon H. (1875) Stirpes exoticae novac. Adansonia 11 : 292-312.

Baillon H. (1875-1876) Histoire des plantes 6: 137-215 [Ulmacées]. Paris.

Baillon H. (1895), in Grandidier A., Histoire physique, naturelle et politique de Madagascar 35. Histoire naturelle des plantes 5. Atlas 3 (1894-1897). Paris.

Bentham G. \& Hooker J.D. (1865) Genera plantarum 1 (2): 600-629 [Rosaceae]. London.

Bentham G. \& Hooker J.D. (1880) Genera plantarum 3 (1): 341-395 [Urticaceae]. London.

Berg C.C. (1972a) A new species of Helianthostylis (Moraceae). Acta Bot. Neerl. 21 : 99-101.

Berg C.C. (1972b) Olmedieae and Brosimeae (Moraceae). Fl. Neotropica Monogr. 7 : 228 p. New York.

Berg C.C. (1973) Some remarks on the classification and differentiation of Moraceae. Meded. Bot. Mus. Herb. Rijksuniv. Utrecht 386:10 p.

Berg C.C. (1977) The Castilleae, a tribe of the Moraceae, renamed and redefined due to the exclusion of the type genus Olmedia from the "Olmedieae". Acta Bot. Neerl. 26 : 73-82.

Berg C.C. \& Hijman M.E.E. (1977) A precursor to the treatment of Dorstenia for the floras of Cameroun and Gabon. Adansonia, ser 2, $16: 415-443$.

Bernbeck F. (1932) Vergleichende Morphologie Urticaceen- und Moraceen-Infloreszenzen. Bot. Abh. 19 : 100 p.

Blume C.L. (1856) Museum botanicum Lugduno-Batavum 2: 75-88 [Artocarpeae]. Leiden.

Bosser J. \& Léandri J. Au sujet du Fatoua madagascariensis Léand. Le Naturaliste Malgache $9:$ 37-40.

Brazier J.D. \& Franklin G.L. (1961) Identification of hardwoods. For. Prod. Res. Bull. 46 : 96 p. London.

Bojer W. (1837) Hortus mauritianus : $456 \mathrm{p}$.

Brown N.E. (1894) Three new species of Treculia. Kew Bull. 1894 : 359-361.

Bureau E. (1873), in de Candolle Alph., Prodromus systematis naturalis regni vegetabilis 17: 211-279 [Moraceae]. Paris. 
Capuron R. (1968) Vingt fiches botanique d'essence forestière de Madagascar. Publ. Centre Technique Forestier Tropical Madagascar.

Capuron R. (1972) Contribution à l'étude de la flore forestière de Madagascar. Adansonia, ser. 2, $12: 375-388$.

Candolle A.P. de (1825), in de Candolle A.P., Prodromus systematis naturalis regni vegetabilis 2: 515-639 [Rosaceae]. Paris.

Chevalier A. (1909) Les végétaux utiles de l'Afrique tropicale française 5, Première étude sur les bois de la Côte d'Ivoire : 258-265 [Urticées]. Paris.

Chevalier A. (1912) Novitates flora africanae. Bull. Soc. Bot. Fr. 58 (Mém. 8d) : 136-224 (Urticaceae : 207-211).

Chevalier A. (1949) Sur un Mûrier africain. Rev. Bot. Appl. Agr. Trop. 29 : 69-74.

Coq C. Le (1963) Contributions à l'étude cyto-taxinomique des Moracées et des Urticacées. Rev. Gén. Bot. 70 : 385-426.

Coq C. Le (1964) Étude cyto-taxinomique de six Moracées. Bull. Mus. Hist. Nat., Paris, ser. 2, $36(6)$ : 869-873.

Cordemoy E.J. de (1895) Flore de l'Ile de la Réunion : 547 p. Paris.

Comer E.J.H. (1962) The classification of Moraceae. Gard. Bull. Singapore 19 : 187-252.

Corner E.J.H. (1970) New species of Streblus and Ficus (Moraceae). Blumea 18 : 393-411.

Cross G.L. (1936) The structure of the growing point and the development of the bud scales of Morus alba. Bull. Torrey Bot. Club 63: 451-465.

Cross G.L. (1937) The origin and the development of the foliage leaves and stipules of Morus alba. Bull. Torrey Bot. Club $64:$ 145-163.

Dale I.R. \& Greenway P.J. (1961) Kenya trees and shrubs : 654 p. London.

Decaisne J. (1847), in Trécul, Sur la famille des Artocarpées. Ann. Sci. Nat., Bot., ser. 3, 8: 38-157 (Tréculia : 108-109).

Duchartre P.E.S. (1863), in Maillard, Notes sur l'Ile de la Réunion (Bourbon), Annexe Phanérogamique. Paris.

Engler G.H.A. (1889), in Engler \& Prantl, Die Natürlichen Pflanzenfamilien 3 (1) (Moraceae : 66-98). Leipzig.

Engler G.H.A. (1894) Moraceae africanae I. Bot. Jahrb. 20 : 139-150.

Engler G.H.A. (1897), in Engler \& Prantl, Die Natürlichen Pflanzenfamilien, Nachtrag zu Teil 2-4 (Moraceae: 119-122). Leipzig.

Engler G.H.A. (1898) Monographieen Afrikanischer Pflanzenfamilien und -gattungen 1. Moraceae (excl. Ficus) : 1-50, t. 1-18. Leipzig.

Engler G.H.A. (1902) Moraceae africanae II. Bot. Jahrb. 33 : 114-119.

Engler G.H.A. (1907) Moraceae africanae III. Bot. Jahrb. 39 : 573-574.

Engler G.H.A. (1908) Moraceae africanae IV. Bot. Jahrb. 40 : 543-549.

Engler G H.A. (1914) Moraceae africanae VI. Bot. Jahrb. 51 : 426-439.

Engler G.H.A. (1915), in Engler \& Drude, Die Vegetation der Erde 9. Die Pflanzenwelt Afrikas 3 (1) (Moraceae : 17-51). Leipzig.

Fedorov A.A. (1969) Chromosome numbers of flowering plants : 927 p. Leningrad. Fosberg F.R. (1974) Miscellaneous notes on the flora of Aldabra and neighbouring islands III. Kew Bull. 29 : 253-266.

Gadella T.W.J. \& Kliphuis E. (1969) Chromosome numbers of some Angiospermae collected in Cameroun and Ivory Coast. Proc. Roy. Neth. Acad. Sci., ser. C, 72 : 306-310.

Gaudichaud Ch. (1826-1830) Botanique, in Freycinet L. de, Voyage autour du monde, ... exécuté sur les corvettes de S.M. l'Uranie et la Physicienne : 522 p. Paris.

Hallé F. \& Oldeman R.A.A. (1970) Essai sur l'architecture et la dynamique de croissance des arbres tropicaux : 178 p. Paris.

Hasskarl J.K. (1844) Catalogus plantarum in horto botanico bogoriensis cultarum : 391 p. Batavia.

Hauman L. (1948) Moraceae, in Flore du Congo Belge et du Ruanda-Urundi 1 : 52-98. Bruxelles, I.N.E.A.C.

Hiern W.P. (1900) Catalogue of the African plants collected by Dr. Friedrich Welwitsch 4 : 785-1035. London.

Hutchinson J. (1917) Moraceae, in Prain, Flora of Tropical Africa 6 (2): 78-230. London. 
Hutchinson J. (1919) Diagnoses africanae LXXII. Kew Bull. 1919 : 263-267.

Hutchinson J. \& Dalziel J.M. (1937) The useful plants of West Tropical Africa : 612 p. London.

Irvine F.R. (1961) Woody plants of Ghana. London.

Jacquin N.J. von (1791) Collectanea ad botanicam, chemicam et historiam naturalem spectantia 3. Wien.

Jarret F.M. (1959-1960) Studies in Artocarpus and allied genera. Journ. Arnold Arb. $40: 1-37,113-155,298-368 ; 41: 73-140,320-340$.

Jumelle H. (1920) La Katoka, arbre à graines comestibles. C.R. Acad. Sci. Paris 171 : 924-926.

Kaastra R.C. (1973) Description and taxonomic position of Maclura brasiliensis (Moraceae). Acta Bot. Neerl. 22 : 69-74.

Kerharo J. \& Bouquet A. (1950) Plantes medicinales et toxiques de la Côte d'Ivoire Haute Volta. Paris, O.R.S.T.O.M.

Kirk J. (1867) On a new dye-wood of the genus Cudranea from East Tropical Africa. Journ. Linn. Soc. [Lond.], Bot. $9: 229-230$.

Lawton R.M. (1955) The relationship between crown form and sex in Chlorophora excelsa. Commonw. For. Rev. 34 : 294.

Léandri J. (1948a) Contribution à l'étude des "Artocarpoideae" de Madagascar. Not. Syst. 13 (3) : 171-181.

Léandrí J. (1948b) Contribution à l'étude des Moracées de Madagascar (Moroideae). Mém. Inst. Sci. Madag., ser. B, 1 : 1-37.

Léonard J. (1947) Notulae systematiceae I. Bull. Jard. Bot. Etat. Brux. 18 : 145-153.

Leroy J.F. (1949) Les Mûriers sauvages et cultivés. La sériciculture sous les tropiques.

Rev. Bot. Appl. Agr. Trop. 29 : 481-496.

Leschenault L.T. (1810) Mémoire sur le Strychnos tiente et l'Antiaris toxicaria, plantes vénéneuses de l'île de Java, avec le suc desquelles les indigènes empoisonnent leurs flèches et sur l'Andira harsfieldii, plante médicinale du même pays. Ann. Mus. Hist. Nat.

Paris 16 : 459-482.

Lynch R.I (1877) On the disarticulation of branches. Journ. Linn. Soc. [Lond.], Bot. 16: $180-183$.

Mangenot S. \& Mangenot G. (1958) Deuxième liste de nombres chromosomiques nouveaux chez diverses Dicotylédones et Monocotylédones d'Afrique occidentale. Bull. Jard. Bot. Etat. Brux. 28 : 315-329.

Mildbraed J. (1922) Morus lactea (Sim) Mildbr. Notizbl. Bot. Gart. Berlin 8 : 243-244. Millington W.F \& Chaney W.R. (1973) Shedding of shoots and branches, in Kozlowski, Shedding of plant parts : 149-204. New York-London.

Normand D. (1950) Atlas des bois de la Côte d'Ivoire 1: 1-46. Nogent-sur-Marne, Publ. Centre Technique Forestier Tropical.

Osmaston H.A. (1965) Pollen and seed dispersal in Chlorophora excelsa and other Moraceae, and in Parkia filicoidea (Mimosaceae), with special reference to the role of the fruit bat, Edidolon helvum. Commonw. For. Rev. 44: 96-104.

Overbeck F. (1923) Zur Kenntnis des Mechanismus der Samenausschleuderung von Oxalis. Jahrb. Wiss. Bot. 62 : 258-282.

Overbeck F. (1924) Studien an den Turgeszenzschleudermechanismen von Dorstenia contrajerva L. and Impatiens parviflora DC. Jahrb. Wiss. Bot. 63 : 467-499.

Overbeck F. (1926) Turgeszenzschleudermechanismen zur Verbreitung von Samen und Früchten. Die Naturwissenschaften 14: 969-976.

Perrier de la Bâthie H. (1927) Les genres Illigera et Antiaris à Madagascar. Arch. Bot. Bull., Caen 1 : 69-71.

Perrier de la Bâthie H. \& Léandri J. (1952), in Humbert, Flore de Madagascar et des Comores 55 (Moraceae) : 76 p. Paris.

Petit-Thouars L.M.A. Du (1806) Genera nova madagascariensia : 29 p. Paris.

Poiret J.L.M. (1797), in Lamarck, Encyclopédie méthodique. Botanique 4: 373-382 [Mûrier]. Paris.

Pijl L.van der (1953) On the flower biology of some plants from Java. Ann. Bogoriensis 1 : 77.99.

Pijl L.van der (1972) Principles of dispersal of higher plants. ed. 2 : 161 p. Berlin-Heidelberg-New York. 
Rendle A.B. (1916), in Prain, Flora of Tropical Africa 6 (2) (Ulmaceae: 1-14; Moraceae: 19-78). London.

Richter A. (1895) Die anatomischen und systematischen Verhältnisse dreier problematischer Genera der tropischen Flora: Cudrania, Plecospermum und Cardiogyne. Term. Fazetek 18 : 294-307, t. 5, 6.

Roxburgh W. (1832) Flora indica $3: 875$ p. London.

Schleuss G. (1958) Ueber die Fruchtentwicklung der Gattung Dorstenia, insondere über ihren Turgeszenz-Schleudermechanismus. Planta 52 : 276-319.

Seringe N.-C. (1855) Description et culture des Mûriers : 336 p., 27 fig. Paris.

Sim T.R. (1909) Forest flora and forest resources of Portuguese East Africa : 166 p. 100 fig. Aberdeen.

Smith C.A. (1963) Shoot apices in the family Moraceae with a seasonal study of Maclura pomifera (Raf.) Schneid. Bull. Torrey Bot. Club 90 : 237-258.

Stapf O. (1906), Urticaceae, in Johnston, Liberia 2 : 650-654. London.

Stapf O. (1909) Diagnoses plantarum africanae. Plantes nouvelles de l'Afrique tropicale francaise. Artocarpeae. Journ. Bot. [Paris], ser. 2, 2 : 99-100.

Tippo O. (1938) Comparative anatomy of the Moraceae and their presumed allies. Bot. Gaz. 100 : $1-99$.

Tison A. (1906) Remarques sur la chute des bougeons terminaux de certains arbres. Bull. Soc. Linn. Normandie, ser. 5, 9 : 164-180, t. $1,2$.

Trimen H. (1898) A handbook of the Flora of Ceylon 4: 384 p. London.

Trécul A. (1847) Sur la famille des Artocarpées. Ann. Sci. Nat., Bot., ser. 3, 8 : 38-157, t. 1-6.

Vigne C. (1931) Note on Chlorophora excelsa in the Gold Coast. Trop. Woods 28 : 7-10.

Voorhoeve A.G. (1965) Liberian high forest trees : 416 p. Wageningen.

Walker A.R. (1953) Usages pharmaceutiques de Dlantes spontanées de Gabon. Bull. Inst. Etud. Centrafr., ser. nov. 6 : 275-329.

Welwitsch F.M.J. (1869) Sertum angolense. Trans. Linn. Soc. [Lond.], Bot. 27 : 1-110, t. 7-28.

White M.G. (1966) A comparison of Chlorophora excelsa (Welw.) Benth. and Hook. (F.) and C. regia A. Chev. (Fam. Moraceae). Commonw. For. Rev. 45: 150-155.

Wildeman E. De \& Durand Th. (1899) Contributions à la flore du Congo. Ann. Mus. Congo, Bot., ser. 2,1 (1): 1-72.

Wildeman E. De \& Durand Th. (1900) Illustrations de la flore du Congo. Ann. Mus. Congo, Bot., ser. 1, 1 (6): :121-144:

Wildeman E. De \& Durand Th. (1901) Plantae Gilletianae congolenses. Bull. Herb. Boiss., ser. 2, $1(9)$ : 825-852.

Wildeman E. De \& Durand Th. (1903) Études sur la flora du Bas-Congo et MoyenCongo. Ann. Mus. Congo, Bot., ser. 5, 1 : 1-344 (1903-1906).

Wildeman E. De (1914) Neue Arten aus Zentral-Afrika (Belgisch-Kongo) 1. Repert. Sp. Nov. 13 : 369-384.

Willemet R. (1796) Herbarium mauritianum, in Usteri, Annalen der Botanick 18 (or 12) : $1-64$.

Wit H.C.D. de (1963) De wereld der planten 1 : 331 p. Den Haag. 


\section{INDEX OF NAMES OF THE SYSTEMATIC PART}

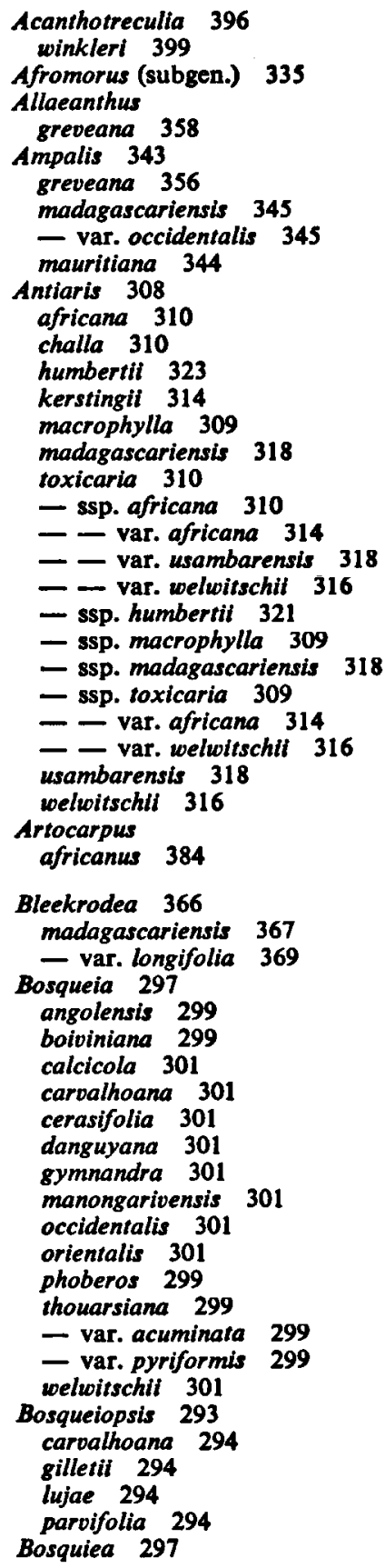

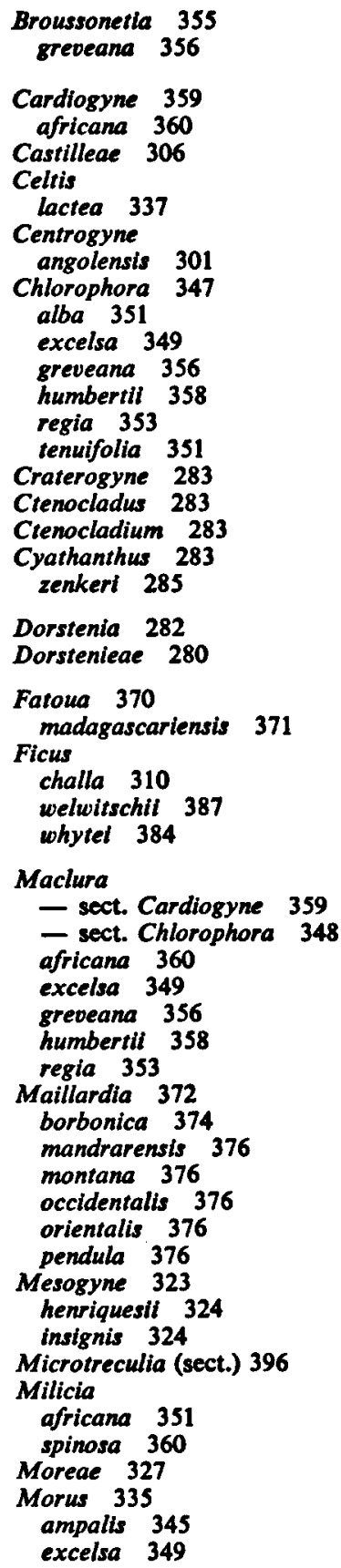




\author{
lactea 337 \\ mauritiana 344 \\ mesozygia 337 \\ - var. colossea 337 \\ - var. lactea 337 \\ - var. sanda 337 \\ nitida 345 \\ rigida 345 \\ Myriopeltis \\ edulis 384 \\ Neosloetiopsis 363 \\ kamerunensis 364 \\ Pachytrophe 339 \\ dimepate 340 \\ obovata 341 \\ - var. laurifolia 341 \\ - var. montana 341
}

Parastreblus (subg.) 343

Plecospermum

bureaui 341

laurifolium 341

Pontya 297

excelsa 301

Pseudotreculia 396

Scyphosyce 283

gilletii 286

manniana 285

pandurata 288

zenkeri 285

Sloetiopsis 363

usambarensis 364

Streblus 328

- sect. Bleekrodea 367

madagascariensis 367

maritimus 345

mauritianus 344

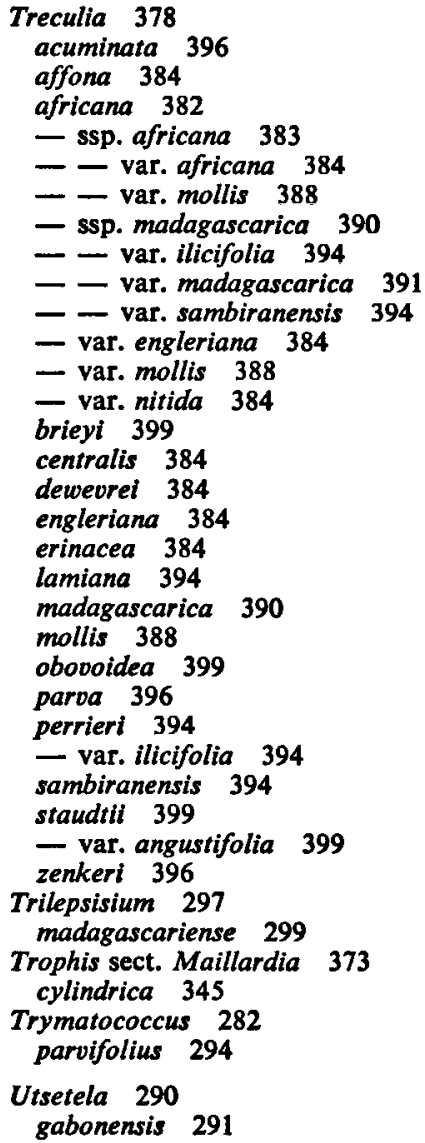

\section{LIST OF ASIAN AND AMERICAN TAXA REFERRED TO OR DISCUSSED IN THE PRESENT STUDY}

Allaeanthus 356,360

Antiaropsis 272, 273, 307, 327, 330

Artocarpus 387

Bagassa 273, 333, 348, 360

Batocarpus 348

Brosimum 280, 282

Broussonetia 330, 348, 356, 360

Calpidochlamys 333, 373

Chlorophora 348

Clarisia 334, 374

Cudrania 331, 360

Helianthostylis 272, 280, 281, 282, 290 291, 367

Maclura 328, 331, 356, 360

Malaisia 273
Morus 336, 348

Olmedia 272, 307, 373, 374

Parartocarpus 334, 379

Phyllochlamys 272, 273, 330

Plecospermum 331, 340, 360

Prainea 273, 327, 328

Pseudolmedia 373

Sloetia 282, 328, 364, 367, 370

Sorocea 273, 334, 374

Sparattosyce 272, 307

Streblus 327, 328, 330, 331, 336, 340 344, 364, 367

Trophis 272, 273, 328, 333, 344, 374

Trymatococcus 280, 282, 294 